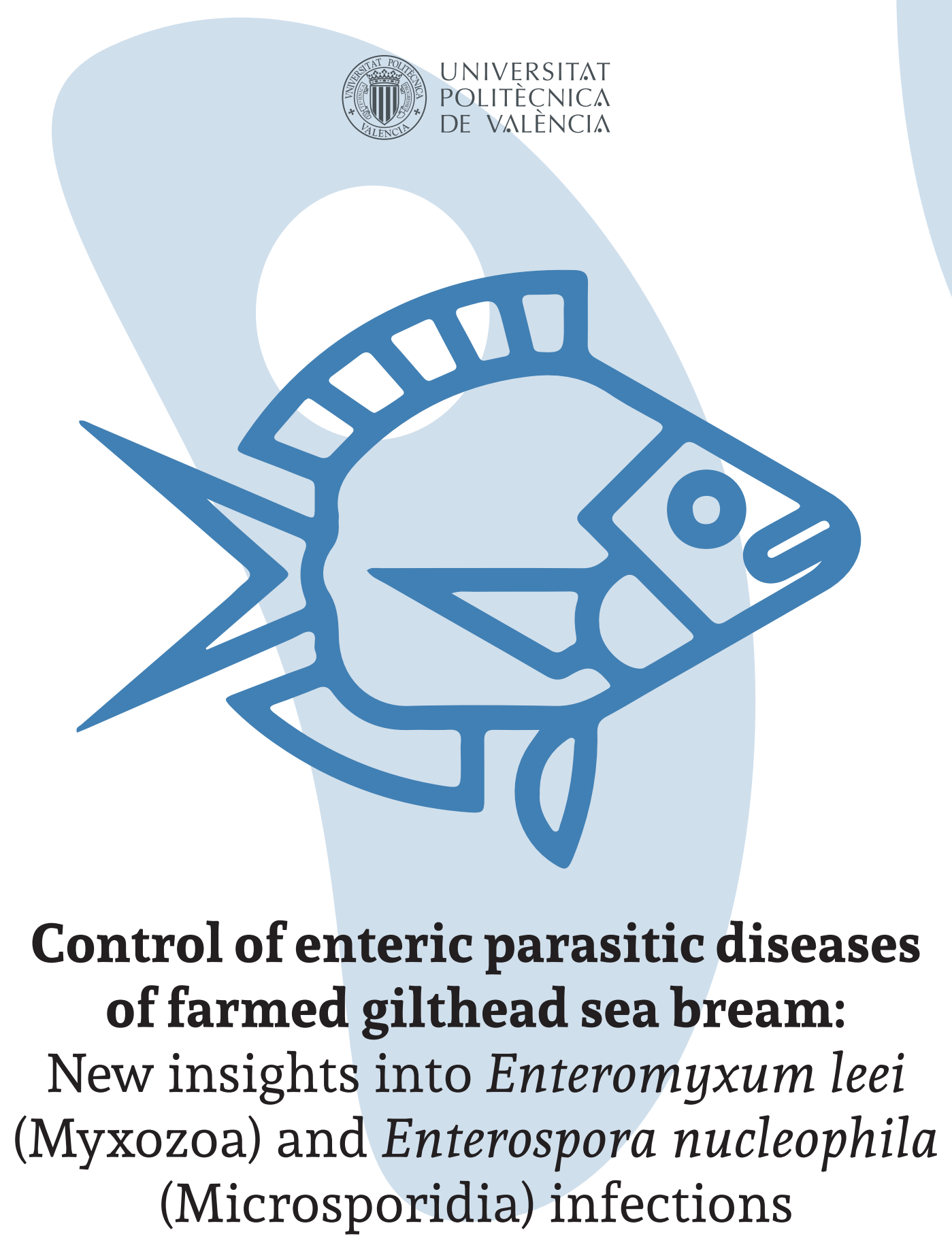

Memoria presentada para optar al Grado de Doctora en

Ciencia y Tecnología de la Producción Animal por:

María Amparo Picard Sánchez

Dirigida por:

Ariadna Sitjà Bobadilla

Oswaldo Palenzuela Ruíz

M. Carla Piazzon de Haro

Valencia, marzo 2021

\section{Q) IATS}

Instituto de Acuicultura Torre de la Sal

\section{CSIC}

Consejo Superior de Investigaciones Científicas 



\title{
Control of enteric parasitic diseases of farmed gilthead sea bream: \\ New insights into Enteromyxum leei (Myxozoa) and Enterospora nucleophila (Microsporidia) infections
}

\author{
María Amparo Picard Sánchez
}


Diseño y maquetación:

KAIZEN GROUP @ 2020

María Amparo Picard Sánchez

ORCID: https://orcid.org/0000-0002-0871-5444 




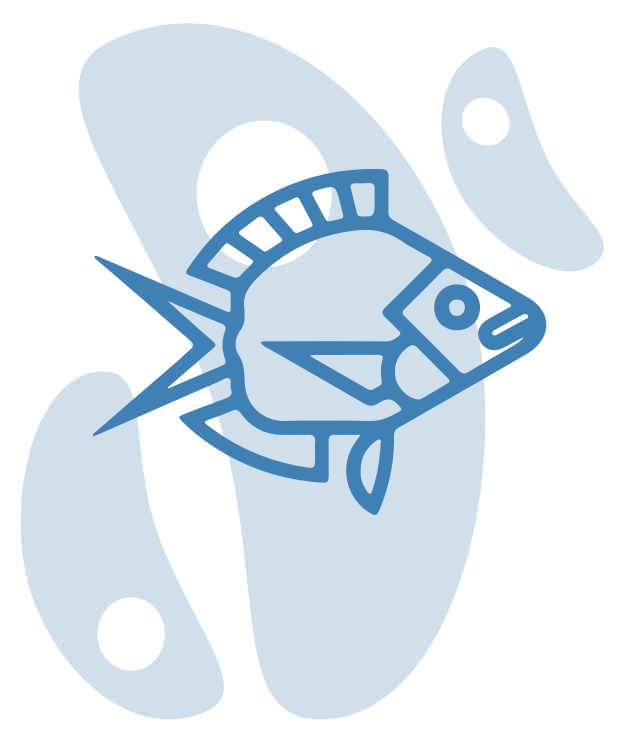

Ariadna Sitjà Bobadilla, Oswaldo Palenzuela Ruíz, y María Carla Piazzon de Haro, investigadores del grupo de Patología de Peces del Departamento de Biología, Cultivo y Patología de Especies Marinas del Instituto de Acuicultura Torre de la Sal, Consejo Superior de Investigaciones Científicas,

Informan: Que la presente Tesis Doctoral titulada "Control of enteric parasitic diseases of farmed gilthead sea bream: New insights into Enteromyxum leei (Myxozoa) and Enterospora nucleophila (Microsporidia) infections", presentada por Doña María Amparo Picard Sánchez, para optar al grado de Doctora en Ciencia y Tecnología de la Producción Animal, ha sido realizada dentro de la sublínea de investigación "Nutrición y Salud Animal en Acuicultura Marina" del Instituto de Acuicultura Torre de la Sal bajo nuestra dirección y, considerándola concluida, autorizamos su presentación a fin de que pueda ser juzgada por el tribunal correspondiente.

Castellón, marzo de 2021

Fdo: Ariadna Sitjà Bobadilla

Fdo: Oswaldo Palenzuela Ruíz

Fdo: M. Carla Piazzon de Haro

Fdo: María Amparo Picard Sánchez 


\section{Apoyo institucional}

La presente tesis ha sido realizada gracias a un contrato predoctoral (Personal Investigador en Formación) de 4 años otorgado a María Amparo Picard Sánchez dentro del Proyecto Europeo ParaFishControl (Horizon2020, GA n 634429) y coordinado por el CSIC, entre marzo 2016 y marzo de 2020. Durante este periodo la estudiante realizó dos estancias en el extranjero. La primera estancia tuvo una duración de 2 meses en la Universidad de Aberdeen (Escocia, Reino Unido) y fue costeada parcialmente por el proyecto del ParaFishControl. La segunda estancia, de 2.1 meses en CAS Biology Centre (České Budějovice, República Checa), fue costeada por el proyecto ParaFishControl y por una ayuda ERASMUS+ concedida por la Universidad Politécnica de Valencia. 


\section{Agradecimientos}

En primer lugar, quería agradecer a Ariadna, Oswaldo, y Carla, el haberme dado la oportunidad de formar parte de este magnífico laboratorio estos cuatro años. Ha sido una grandísima experiencia y me ha ayudado a crecer mucho como persona e investigadora. A Carla, además agradecerle la paciencia en el laboratorio, y los consejos científicos y de vida en general.

Por otro lado, agradecer a las compañeras de la continua batalla de 'porculización' de las pobres doraditas, 'Itziar' y 'Raquel', por enseñarme todo con paciencia, profesionalidad y buen rollo - . No podría haber tenido mejores compañeras de trabajo, y de baile, no cambiéis nunca! Por otro lado, gracias Félix, por tu paciencia y trabajo en todos los muestreos, eres genial! También agradecer a Pepe y Lucinda tooooodos los cortes de histología que me hicieron, y por acompañarlos siempre con humor y sonrisas, sois muy grandes! :D

Por otra parte agradezco al Profesor Jaume Pérez Sánchez y a todo el grupo de Nutrigenómica y endocrinología del crecimiento del IATS por su colaboración a lo largo de mi tesis, y por haberme dado la oportunidad de formar parte de sus trabajos. Y gracias también al resto de estudiantes predoctorales del IATS (Paula, Lucia, Nando, Quique, Migué...) por las risas por los pasillos, habéis sido geniales compañeros. Por último, agradecer la paciencia y la eficacia de Charo, recibiéndonos siempre con su mejor sonrisa. Del mismo modo, agradecer a Carmen Galán y Paloma Rueda, las chicas de Ingenasa (Madrid), por su colaboración en la búsqueda de candidatos diagnóstico frente parásitos.

Y por supuesto, gracias a mi gran amigo David Cordero, gracias por tus consejos, tu sabiduría, tu paciencia, por tus recetas de cocina para preparar pescado, por ser tú mismo conmigo y permitirme ser yo misma y por mil cosas más... GRACIAS! Por último, quería agradecer al todos los trabajadores del IATS, porque sin ellos, no sería posible el funcionamiento del centro.

Quería agradecer a Chris Secombes y Marc Faber, el permitirme aprender a su lado durante mi estancia en la Universidad de Aberdeen, todo lo que se sobre transcriptómica. Y también a todos los que hicieron esa estancia mucho más divertida. En especial a Álvaro, Jerry y Ayham, que me enseñaron que en ciencia la gente también puede ser muuuuuuy divertida. También agradecer al grupo de Astrid Holzer, de la Universidad de CAS Biology Centre (Ceske Budejovide), por su cálida acogida y por mostrarme parte del mundo checo y que un grupo de trabajo puede ser una micro familia $(-)$

Por supuesto, agradecer el apoyo moral a mi familia, sin ellos no sería ni estaría donde estoy. En especial a mi madre y a Jesús, por quererme y aguantarme incondicionalmente, y porque no podría haber imaginado ni deseado un apoyo mejor.

Y en general agradecer a todas las personas que han pasado por mi vida estos años, y me han regalado parte de su tiempo y su sabiduría.

¡GRACIAS A TODOS! $:$ 


\section{Abstract}


In the last few decades, aquaculture production has experienced an enormous growth, and currently exceeds the supplies from capture fisheries production. However, this production is being hampered by the emergence of a number of diseases in the various fish farming systems. Among them, mostly those that are caused by parasites are the ones that lead to significant economic losses. Gilthead sea bream (Sparus aurata) is a marine fish produced mainly in the Mediterranean Sea. In this Doctoral Thesis two enteric parasites of gilthead sea bream are studied: Enteromyxum leei (Myxozoa) and Enterospora nucleophila (Microsporidia). Both parasites represent a threat to the cultivation of sea bream and there is no vaccine or treatment against them. To date, no in vitro culture has been established for either parasite, and only for E. leei was it possible to establish a model for maintaining the infection in vivo. The difficulty to isolate these parasites has hindered their study as well as the development of preventive or palliative measures. The aim of this thesis is to gain new knowledge about these parasites and their relationship with the host, also the basic foundations for generating solutions that can be applied in aquaculture.

Regarding E. leei, the existence of a protocol for experimental infection made possible to carry out previous works on the parasite-host relationship, which have provided a solid knowledge base for this thesis. The general objective for this parasite was to study the acquired immunity induced in gilthead bream and the possibility of generating diagnostic tools and vaccines against this disease.

Acquired immunity of sea bream against E. leei was shown using fish that had survived a previous infection with $E$. leei and fish that had never been in contact with the parasite before. Both types of fish were challenged against the pathogen by exposure via effluent. Results showed that re-exposed fish were not infected and that resistance lasts for at least 16 months. Furthermore, resistance seemed to be correlated with high levels of specific immunoglobulin (Ig) M in blood, and a high expression of Igs, in particular, the soluble forms, even before re-exposure to the parasite. It was also shown that the acquired response leads to an increase in other immune factors at the local and systemic levels, such as the expression of genes related to cytotoxicity (granzyme A), complement activity ( $c 3$ and fucolectin), and serum peroxidase. Also, in contrast to fish exposed for the first time, re-exposed fish showed a phenotype of resolution of inflammation in both the gut and the anterior kidney (low expression of il1 $\beta$ and $h s p 90 \alpha$, and high expression of il10).

The next step was focused on refining the protocol for effluent infection with E. leei by studying infection at different exposure time points, temperatures and population densities. To this end, two effluent infections were carried out at two temperatures $\left(18^{\circ} \mathrm{C}\right.$ constant and $25.6^{\circ} \mathrm{C}$ on average), at different exposure times to the effluent, and with different fish population densities. The results showed that one week of exposure is sufficient to spread $E$. leei infection by effluent, regardless of temperature. Furthermore, at low temperature exposures $\left(18^{\circ} \mathrm{C}\right)$, the immune response to the parasite (production of specific antibodies) of the fish was lower than at high temperatures $\left(25.6^{\circ} \mathrm{C}\right)$. Thus, although the prevalence of infection was higher at higher temperatures, the increased activation of the immune system resulted in a slower progression of the infection through the intestine. Among the conclusions, it can be 
highlighted that keeping infected fish together with healthy fish in the same tank always leads to higher prevalence regardless of temperature, hence, the systematic elimination of symptomatic fish could substantially decrease the prevalence of infection. On the other hand, the effects upon the prevalence of infection resulting from high densities or time of exposure were accentuated at low temperatures.

After demonstrating the effective adaptive response to E. leei, and with a more refined infection model allowing shorter exposure times, a passive immunization assay was performed using resistant fish serum to test the potential protective capacity of their specific antibodies. The results showed that the serum with specific antibodies effectively slows down the invasion of the gut by the parasite and reduces the symptoms of the disease (stunting, loss of lipid reserves in the liver, etc.). At the same time, an analysis of the repertoire of the variable regions of intestinal IgM and IgT of these resistant fish was carried out to find out in detail the type of response induced by the parasite. An induction of a polyclonal response in $\operatorname{IgM}^{+}$and $\operatorname{IgT}^{+} \mathrm{B}$ cells was discovered, which was probably part of an immune system evasion strategy by the parasite. However, the number of specific antibodies produced by the resistant fish (although it was not a monoclonal response) was sufficient to provide protection from the parasite.

On the basis of these results, a research was carried out for E. leei antigens that could have use as candidates for the production of vaccines or diagnostic tools. To do this, a de novo transcriptome was assembled using a mixed sample of gilthead sea bream and parasite. The assembled transcripts were filtered through blastn with two databases: one from Teleosteans and one from Cnidarians/Myxozoans. A total of 14,356 transcripts belonging to E. leei were obtained, which constituted the parasite transcriptome and were used to search for antigenic targets through proteomic and in silico studies. The proteomic study was focused on the findings for vaccine candidates. The study was performed using western blot with resistant fish sera and $E$. leei antigen and sequencing the bands recognized by the specific antibodies, by means of mass spectrometry. The in silico research was used for the diagnostic identification of the candidates and it was based on predictive programs using high levels of expression and extracellular localization as parameters. The results of the in silico search resulted in 7 transcripts, which are being used for the production of monoclonal antibodies for diagnostic use. In addition, in proteomic analysis, twelve candidates were obtained that will be used to generate recombinant proteins for vaccine production.

The starting point was much more basic concerning the studies related to E. nucleophila, since this is an emerging and very recently described disease. The samples of this parasite can only be obtained from natural outbreaks in fish farms and so far, no in vivo maintenance protocol has been established. Therefore, first study was carried out to characterize the pathology of the infection of naturally infected fish. In the early stages of the infection, the parasite is mainly located in the intestine, but months later, the prevalence is lower in the intestine and increases in the hematopoietic organs and the stomach. A correlation was detected between infection intensity and stunting. Clinical signs of infection were significant reduction in 
growth, wasting, and intestinal walls paleness. At the cellular level, in the most severe cases hypercellularity in the intestinal epithelium, proliferation of rodlet cells, high number of lymphocytes at the base of the epithelium and infiltration of acidophilic granulocytes in the intestinal epithelium were observed. Furthermore, in the submucosa, the production of granulomas formed by macrophages and surrounded by lymphocytes and granulocytes were observed. Also, in the submucosa, a large abundance of B cells (IgM+ ${ }^{+}$and $\left.\operatorname{IgT}^{+}\right)$, and mast cells $\left(\mathrm{His}^{+}\right)$was described.

Finally, horizontal transmission of E. nucleophila was tried using different transmission methods with the aim of developing an in vivo maintenance model to facilitate future studies with this parasite. The transmission routes tested were cohabitation, effluent, and oral and anal intubation. Transmission of the parasite was achieved with all routes, but there was a decrease in prevalence over time in all cases except for the anal route. Variables such as temperature, dose, and the status of the donor fish appear to be more important than the selected route. Among the routes tested, anal intubation seemed to be the most promising, as it was sustained over a longer period of time, but none of them was able to reproduce the same clinical signs of infection observed in natural infections.

In summary, studies with $E$. leei showed that vaccination against this parasite is feasible, as gilthead sea bream is able to mount an effective and long-lasting targeted response to the pathogen. As a result, very promising candidates were identified for the development of diagnostic methods and vaccines of great potential use in aquaculture. Furthermore, this thesis describes in detail the pathology caused by the emerging pathogen E. nucleophila and explores different experimental transmission routes. These results present a great advance in our knowledge of the disease and will help in optimizing in vivo infection protocols that will facilitate the study of this unknown parasite in order to find solutions applicable to the culture of gilthead sea bream. 


\section{Resum}


En les últimes dècades la producció en aqüicultura ha patit un enorme creixement, superant actualment a les captures de les pesqueres. No obstant això, aquesta producció es veu afectada per l'aparició de malalties en els diferents sistemes de cria de peixos. Entre elles, les causades per paràsits que produeixen significatives pèrdues econòmiques. L'orada (Sparus aurata) és un peix marí present principalment en la mar Mediterrània. En la present tesi doctoral s'estudien dos paràsits entèrics de l'orada: Enteromyxum leei (Myxozoa) i Enterospora nucleophila (Microsporidia). Tots dos paràsits representen una amenaça per al cultiu de l'orada i no existeixen vacunes ni tractaments per a combatre'ls. Fins ara, no s'hi ha establit cap cultiu in vitro per a cap dels dos paràsits, i només per a E. leei s'ha aconseguit un model de manteniment de la infecció in vivo. La dificultat per a aïllar aquests paràsits ha obstaculitzat l'estudi i desenvolupament de mesures preventives o pal-liatives. La present tesi pretén incrementar el coneixement sobre aquests paràsits i les seues relacions amb l'hoste, desenvolupant les bases per a generar solucions que puguen ser aplicades en l'aqüicultura.

En el cas de E. leei, la disponibilitat d'un protocol d'infecció experimental va possibilitar multitud de treballs previs sobre la relació paràsit-hoste, que han suposat una base sòlida de coneixement per a aquesta tesi. L'objectiu general amb aquest paràsit va ser estudiar la immunitat adquirida induïda en l'orada i la possibilitat de generar eines de diagnòstic i vacunes front aquesta malaltia.

La immunitat adquirida de l'orada en contra de E. leei es va demostrar utilitzant peixos que havien sobreviscut a una infecció prèvia amb E. leei i peixos que mai abans havien estat en contacte amb el paràsit. Tots dos tipus de peixos es van exposar a un efluent que contenia estadis infectius del paràsit. Els resultats van mostrar que els peixos re-exposats no es van infectar i que aquesta resistència té una durada d'almenys 16 mesos. A més, la resistència sembla estar correlacionada amb alts nivells d'immunoglobulina (Ig) M específica en sang, i una alta expressió de Igs, en concret, les formes solubles, fins i tot abans de la re-exposició al paràsit. També es va demostrar que la resposta adquirida comporta un augment d'altres factors immunitaris a nivell local i sistèmic, com l'expressió de gens relacionats amb citotoxicitat (granzim A), activitat del complement ( $c 3$ i fucolectina), i peroxidases sèriques. Així mateix, i al contrari que els peixos exposats per primera vegada, els peixos re-exposats van mostrar un fenotip de resolució de la inflamació tant en intestí com en renyó anterior (baixa expressió de il1 $\beta$ i $h s p 90 \alpha$, i alta de il10).

El següent pas es va enfocar en afinar el protocol d'infecció mitjançant efluent amb E. leei, estudiant la infecció a diferents temps d'exposició, temperatures i densitats de població. Per a això, es van realitzar dues infeccions per efluent a dues temperatures $\left(18^{\circ} \mathrm{C}\right.$ constants i $25,6^{\circ} \mathrm{C}$ de mitjana), a diferents temps d'exposició a l'efluent, i amb diferents densitats. Els resultats van mostrar que una setmana d'exposició és suficient per a transmetre la infecció de E. leei per efluent, independentment de la temperatura. A més, en exposicions a baixes temperatures $\left(18^{\circ} \mathrm{C}\right)$, la resposta immunitària per a combatre el paràsit (producció d'anticossos específics) dels peixos va ser menor que a altes temperatures $\left(25,6^{\circ} \mathrm{C}\right)$. D'aquesta forma, encara que la prevalença d'infecció va ser major a temperatures més altes, la major activació del sistema im- 
mune va fer que la progressió de la infecció al llarg de l’intestí fora menor. Entre les conclusions es poden destacar que el manteniment de peixos infectats juntament amb peixos sans dins d'un mateix tanc sempre comporta majors prevalences independentment de la temperatura, i per tant, eliminar sistemàticament peixos amb símptomes podria baixar substancialment la prevalença. D'altra banda, els efectes sobre la prevalença d'infecció derivats d'altes densitats de peixos o temps d'exposició al paràsit s'accentuen a temperatures baixes.

Sobre la base d'aquests resultats, es va realitzar una cerca d'antígens de E. leei que pogueren ser utilitzats com a candidats per a la producció de vacunes o eines de diagnòstic. Per a això, es va assemblar un transcriptoma de novo utilitzant una mostra mixta d'intestí d'orada i paràsit. Els transcrits assemblats es van filtrar per mitjà de 'blastn' amb dues bases de dades: una de Teleòsteus i una altra de Cnidaris/Myxozoos. Es van obtindre 14.356 transcrits pertanyents a E. leei, que van constituir el transcriptom del paràsit i es van utilitzar per a la cerca de dianes antigèniques mitjançant estudis in silico i proteòmics. La cerca in silico es va utilitzar per a la identificació de candidats de diagnòstic i es va basar en programes predictius utilitzant com a paràmetres nivells alts d'expressió i localització extracelul·lar. D'altra banda, l'estudi proteòmic es va centrar en la cerca de candidats vacunals realitzant un western blot amb sèrums de peixos resistents i antigen de E. leei i seqüenciant les bandes reconegudes pels anticossos específics, mitjançant espectrometria de masses. Els resultats de la cerca in silico van donar lloc a 7 transcrits, que estan sent utilitzats per a la producció d'anticossos monoclonals per al seu ús en tècniques per a diagnòstic. A més, en l'anàlisi proteòmic, es van obtindre 12 candidats que s'utilitzaran per a generar proteïnes recombinants per a la producció de vacunes.

En quant als estudis relacionats amb E. nucleophila, pel fet que és una malaltia emergent i descrita molt recentment, el punt de partida va ser molt més inicial. Les mostres d'aquest paràsit només es poden obtindre de brots naturals en piscifactories i fins al moment no s'havia descrit un protocol de manteniment in vivo. Per això, primer es va realitzar un estudi de caracterització de la patologia de la infecció a partir de peixos infectats naturalment. En etapes primerenques de la infecció, el paràsit es localitza principalment a l'intestí, però mesos després, la prevalença en intestí baixa i incrementa en els òrgans hematopoètics i l'estómac. Es va detectar una correlació entre intensitat d'infecció i reducció de creixement. Els signes clínics de la infecció van consistir en una reducció significativa del creixement, aprimament patològic, i pal-lidesa de les parets intestinals. A nivell cel-lular, als casos més greus es va observar hipercel-lularitat en l'epiteli intestinal i proliferació de cèl-lules rodlet, un elevat nombre de limfòcits en la base de l'epiteli i infiltració de granulòcits acidòfils a l'epiteli intestinal. A més, a la submucosa, es va observar la producció de granulomes formats per macròfags i envoltats per limfòcits i granulòcits. També a la submucosa, es va descriure una gran abundància de cèl-lules B (IgM+ ${ }^{+}$igT), i mastòcits (His $\left.{ }^{+}\right)$.

Finalment es van provar diverses formes de transmissió horitzontal de E. nucleophila amb l'objectiu de desenvolupar un model de manteniment in vivo, per a facilitar futurs estudis amb aquest paràsit. Les vies de transmissió provades van ser: cohabitació, efluent i intubació oral i anal. Es va aconseguir la transmissió del paràsit amb 
totes les vies, però es va produir una disminució de la prevalença al llarg del temps en tots els casos excepte per via anal. Variables com la temperatura, la dosi, i l'estat dels peixos donants semblen ser més determinants que la ruta seleccionada per a la transmissió. Entre les rutes provades, la intubació anal sembla ser la més prometedora, ja que es manté en un termini de temps més prolongat, però cap d'elles va ser capaç de reproduir els mateixos signes clínics de la infecció observats en les infeccions naturals.

En resum, els estudis amb E. leei demostren que la vacunació enfront d'aquest paràsit és factible, ja que l'orada és capaç de respondre de forma específica eficaç i duradora enfront del patogen. En conseqüència, es van identificar uns candidats molt prometedors per al desenvolupament de mètodes de diagnòstic i vacunes de gran utilitat en l'aqüicultura. A més, en aquesta tesi es descriu detalladament la patologia ocasionada pel patogen emergent E. nucleophila i s'exploren diferents vies de transmissió experimental. Aquests resultats presenten un gran avanç en el nostre coneixement de la malaltia i ajudaran a optimitzar protocols d'infecció in vivo que facilitaran l'estudi d'aquest desconegut paràsit per a trobar solucions aplicables en el cultiu de l'orada. 


\section{Resumen}


En las últimas décadas la producción en acuicultura ha sufrido un enorme crecimiento, superando actualmente a las capturas de las pesquerías. Sin embargo, esta producción se ve afectada por la aparición de enfermedades en los distintos sistemas de cría de peces. Entre ellas, las causadas por parásitos producen pérdidas económicas significativas. La dorada (Sparus aurata) es un pez marino producido principalmente en el mar Mediterráneo. En la presente tesis doctoral se estudian dos parásitos entéricos de la dorada: Enteromyxum leei (Myxozoa) y Enterospora nucleophila (Microsporidia). Ambos parásitos representan una amenaza para el cultivo de la dorada y no existen vacunas ni tratamientos frente a ellos. Hasta la fecha, para ninguno de los dos parásitos se ha establecido un cultivo in vitro, y sólo para E. leei se ha conseguido establecer un modelo de mantenimiento de la infección in vivo. La dificultad para aislar estos parásitos ha obstaculizado el estudio y desarrollo de medidas preventivas o paliativas. La presente tesis pretende incrementar el conocimiento sobre estos parásitos y sus relaciones con el hospedador, sentando las bases para generar soluciones que puedan ser aplicadas en la acuicultura.

En el caso de E. leei, la disponibilidad de un protocolo de infección experimental posibilitó multitud de trabajos previos sobre la relación parásito-hospedador, que han supuesto una base sólida de conocimiento para esta tesis. El objetivo general con este parásito fue estudiar la inmunidad adquirida inducida en la dorada y la posibilidad de generar herramientas de diagnóstico y vacunas frente a esta enfermedad.

La inmunidad adquirida de la dorada frente a E. leei se demostró utilizando peces que habían sobrevivido a una infección previa con E. leei y peces que nunca antes habían estado en contacto con el parásito. Ambos tipos de peces se retaron con el patógeno mediante exposición vía efluente. Los resultados mostraron que los peces re-expuestos no se infectaron y que esta resistencia tiene una duración de al menos 16 meses. Además, la resistencia parece estar correlacionada con altos niveles de inmunoglobulina (Ig) M específica en sangre, y una alta expresión de Igs, en concreto, las formas solubles, incluso antes de la re-exposición al parásito. También se demostró que la respuesta adquirida conlleva un aumento de otros factores inmunitarios a nivel local y sistémico, como la expresión de genes relacionados con citotoxicidad (granzima A), actividad del complemento ( $c 3$ y fucolectina), y peroxidasas séricas. Asimismo, y al contrario que los peces expuestos por primera vez, los peces re-expuestos mostraron un fenotipo de resolución de la inflamación tanto en intestino como en riñón anterior (baja expresión de il1 $\beta$ y hsp90 $\alpha$, y alta de il10).

El siguiente paso se enfocó a afinar el protocolo de infección mediante efluente con E. leei, estudiando la infección a distintos tiempos de exposición, temperaturas y densidades de población. Para ello, se realizaron dos infecciones por efluente a dos temperaturas $\left(18^{\circ} \mathrm{C}\right.$ constantes y $25,6^{\circ} \mathrm{C}$ de media), a distintos tiempos de exposición al efluente, y con distintas densidades. Los resultados mostraron que una semana de exposición es suficiente para transmitir la infección de E. leei por efluente, independientemente de la temperatura. Además, en exposiciones a bajas temperaturas $\left(18^{\circ} \mathrm{C}\right)$, la respuesta inmunitaria frente al parásito (producción de anticuerpos específicos) de los peces fue menor que a altas temperaturas $\left(25,6^{\circ} \mathrm{C}\right)$. De esta forma, aunque la prevalencia de infección fue mayor a temperaturas más altas, la mayor activación del sistema inmune hizo que la progresión de la infección a lo largo del intestino fuera menor. Entre las conclusiones se pueden destacar que el mantenimiento de peces infectados junto con peces sanos dentro de un mismo tanque siempre conlleva mayores prevalencias independientemente de la temperatura, y por tanto, eliminar sistemáticamente peces con síntomas podría bajar sustancialmente la prevalencia. Por otro lado, los efectos sobre la prevalencia de infección derivados de altas densidades de peces o tiempo de exposición al parásito se acentúan a temperaturas a bajas. 
Tras la demostración de la respuesta adaptativa eficaz frente a E. leei, y al disponer de un modelo de infección más afinado, que permitía tiempos de exposición más cortos, se realizó un ensayo de inmunización pasiva utilizando suero de peces resistentes para testar la posible capacidad protectora de los anticuerpos específicos. Los resultados mostraron que el suero con anticuerpos específicos efectivamente consigue ralentizar la invasión del intestino por el parásito y disminuir los síntomas de la enfermedad (bajada de crecimiento, pérdida de reservas lipídicas en el hígado, etc.). Paralelamente, se realizó un análisis del repertorio de las regiones variables de la IgM e IgT del intestino de dichos peces resistentes para conocer en detalle el tipo de respuesta inducida por el parásito. Se detectó la inducción de una respuesta policlonal en las células B IgM e IgT positivas, probablemente como parte de una estrategia de evasión del sistema inmunitario por parte del parásito. Sin embargo, la cantidad de anticuerpos específicos (pese a no ser una respuesta monoclonal) fue suficiente para conferir protección al individuo.

En base a estos resultados, se realizó una búsqueda de antígenos de E. leei que pudieran ser utilizados como candidatos para la producción de vacunas o herramientas de diagnóstico. Para ello, se ensambló un transcriptoma de novo utilizando una muestra mixta de intestino de dorada y parásito. Los transcritos ensamblados se filtraron por medio de blastn con dos bases de datos: una de Teleosteos y otra de Cnidarios/Myxozoos. Se obtuvieron 14.356 transcritos pertenecientes a E. leei, que constituyeron el transcriptoma del parásito y se utilizaron para la búsqueda de dianas antigénicas mediante estudios in silico y proteómicos. La búsqueda in silico se utilizó para la identificación de candidatos de diagnóstico y se basó en programas predictivos utilizando como parámetros niveles altos de expresión y localización extracelular. El estudio proteómico se centró en la búsqueda de candidatos vacunales realizando un western blot con sueros de peces resistentes y antígeno de E. leei y secuenciando las bandas reconocidas por los anticuerpos específicos, mediante espectrometría de masas. Se obtuvieron doce candidatos que se utilizarán para generar proteínas recombinantes para la producción de vacunas. Por otro lado, los resultados de la búsqueda in silico dieron lugar a 7 transcritos, que están siendo utilizados para la producción de anticuerpos monoclonales para su uso en diagnóstico.

En cuanto a los estudios relacionados con E. nucleophila, debido a que es una enfermedad emergente y descrita muy recientemente, el punto de partida fue mucho más básico. Las muestras de este parásito sólo se pueden obtener de brotes naturales en piscifactorías y hasta el momento no se había descrito un protocolo de mantenimiento in vivo. Por ello, primero se realizó un estudio de caracterización de la patología de la infección a partir de peces infectados naturalmente. En etapas tempranas de la infección, el parásito se localiza principalmente en el intestino, pero meses después, la prevalencia en intestino baja e incrementa en los órganos hematopoyéticos y el estómago. Se detectó una correlación entre intensidad de infección y reducción de crecimiento. Los signos clínicos de la infección consistieron en una reducción significativa del crecimiento, emaciación, y palidez de las paredes intestinales. A nivel celular, en los casos más graves se observó hipercelularidad en el epitelio intestinal y proliferación de células rodlet, un elevado número de linfocitos en la base del epitelio e infiltración de granulocitos acidófilos en el epitelio intestinal. Además, en la submucosa, se observó la producción de granulomas formados por macrófagos y rodeados por linfocitos y granulocitos. También en la submucosa, se describió una gran abundancia de células $B$ $\left(\operatorname{IgM}^{+}\right.$e IgT+), y mastocitos (His ${ }^{+}$.

Finalmente se probaron varias formas de transmisión horizontal de E. nucleophila con el objetivo de desarrollar un modelo de mantenimiento in vivo, para facilitar futuros estudios con este parásito. Las vías de transmisión probadas fueron: cohabitación, efluente e intuba- 
ción oral y anal. Se consiguió la transmisión el parásito con todas las vías, pero se produjo una disminución de la prevalencia a lo largo del tiempo en todos los casos excepto por vía anal. Variables como la temperatura, la dosis, y el estado de los peces donantes parecen ser más determinantes que la ruta seleccionada para la transmisión. Entre las rutas probadas, la intubación anal parece ser la más prometedora, ya que se mantiene en un plazo de tiempo más prolongado, pero ninguna de ellas fue capaz de reproducir los signos clínicos de la infección observados en las infecciones naturales.

En resumen, los estudios con E. leei demuestran que la vacunación frente a este parásito es factible, ya que la dorada es capaz de montar una respuesta específica eficaz y duradera frente al patógeno. En consecuencia, se identificaron unos candidatos muy prometedores para el desarrollo de métodos de diagnóstico y vacunas de gran utilidad en la acuicultura. Además, en esta tesis se describe en detalle la patología ocasionada por el patógeno emergente E. nucleophila y se exploran diferentes vías de transmisión experimental. Estos resultados presentan un gran avance en nuestro conocimiento de la enfermedad y ayudarán a optimizar protocolos de infección in vivo que facilitarán el estudio de este desconocido parásito para encontrar soluciones aplicables en el cultivo de la dorada. 
Abbreviations 


\begin{tabular}{|c|c|}
\hline AI & Anterior intestine \\
\hline c3 & Complement component C3 \\
\hline cDNA & Complementary DNA \\
\hline CDR & Complementarity-determining regions \\
\hline $\mathrm{CF}$ & Condition factor \\
\hline $\mathrm{Ct}$ & Cycle threshold \\
\hline CW & Calcofluor white staining \\
\hline $\mathrm{DD}$ & Degree-days \\
\hline $\mathrm{dpe} / \mathrm{dpc}$ & Days post-exposure/ Days post-challenge \\
\hline dpid & Days post-initial detection \\
\hline EGC & Eosinophilic granular cells \\
\hline FAO & Food and Agriculture Organization \\
\hline fcl & Fucolectin \\
\hline gzma & Granzyme A \\
\hline $\mathrm{HK}$ & Head kidney \\
\hline hsp90a & Heat Shock Protein 90- $\alpha$ \\
\hline ifn $\gamma$ & Interferon $\gamma$ \\
\hline igf I & Insulin-like Growth Factor 1 \\
\hline IGHV & Immunoglobulin heavy chain variable region \\
\hline IHC & Immunohistochemestry \\
\hline il10 & Interleukin 10 \\
\hline $\mathrm{il17a} / \mathrm{f}$ & Interleukin $17 \mathrm{a} / \mathrm{f}$ \\
\hline il1 $\beta$ & Interleukin $1 \beta$ \\
\hline il6 & Interleukin 6 \\
\hline imuc & Intestinal mucin \\
\hline ISH & In situ hibridization \\
\hline lcp I & Leucocyte cysteine proteinase inhibitor 1 \\
\hline mhcIIb & Major Histocompatibility Complex IIb \\
\hline MI & Middle intestine \\
\hline mIgM & Membrane Immunoglobulin M \\
\hline mIgT & Membrane Immunoglobulin $\mathrm{M}$ \\
\hline $\operatorname{mrc1}$ & Mannose Receptor C-Type 1 \\
\hline NAI & Naïve Fish (no previously exposed to the pathogen) \\
\hline NL-/ L-qPCR & Non-lethal- /Lethal qPCR (qPCR, quantitative polymerase chain reaction) \\
\hline PAMP & Pathogen-associated molecular pattern \\
\hline PBS & Phosphate-buffered saline \\
\hline PC & Principal components \\
\hline PI & Posterior intestine \\
\hline PRR & Pattern Recognition Receptor \\
\hline qPCR & Quantitative polymerase chain reaction \\
\hline SGR & Specific growth rate \\
\hline sIgM & Soluble Immunoglobulin M \\
\hline
\end{tabular}


Control of enteric parasitic diseases of farmed gilthead sea bream

$\begin{array}{ll}\text { sIgT } & \text { Soluble Immunoglobulin M } \\ \text { SpAb } & \text { Specific antibodies } \\ \text { SUR } & \text { Survival fish (Fish that survived at least one exposure to the parasite) } \\ \text { TA } & \text { Triamcinolone acetonide } \\ \text { (T-)TBS } & \text { (Tween 20-) Tris Buffered Saline } \\ \text { VH } & \text { Heavy chain variable region } \\ \text { wpe/wpc } & \text { Weeks post-exposure/ Weeks post-challenge } \\ \text { zap70 } & \text { Zeta-chain-associated protein kinase } 70 \\ \alpha 2 \mathrm{~m} & \alpha 2 \text {-macropglobulin } \\ \beta 2 \mathrm{~m} & \beta 2 \text {-macroglobulin } \\ \text { 18S rRNA } & \text { 18S ribosomal RNA }\end{array}$


ABBREVIATIONS 
Table of contents 
1. GENERAL ASPECTS

1. Aquaculture

2. Gilthead sea bream biology and culture

3. Parasitic diseases in cultured gilthead sea bream

2. MYXOZOA

1. General aspects

2. Malacosporea

3. Myxosporea

4. Enteromyxum leei

pag. 35

3. MICROSPORIDIA
1. General aspects
2. Enterospora nucleophila

4. THE IMMUNE SYSTEM OF TELEOST

1. Lymphohematopoietic organs and tissues

2. Innate immune system

3. Acquired immune system

Objectives

pag. 71

Chapter 1. Acquired protective immune response in a fish-myxozoan model encompasses specific antibodies and inflammation resolution

pag. 75 (Fish Shellfish Immunol. 90:349-362, 2019, doi: 10.1016/j.fsi.2019.04.300)

Chapter 2. Water temperature, time of exposure and population density are pag. 117 key parameters in Enteromyxum leei fish-to-fish experimental transmission

(J Fish Dis. 43(4):491-502, 2020, doi: 10.1111/ifd.13147)

Chapter 3. Passive immunization delays disease outcome in gilthead sea bream infected with Enteromyxum leei (Myxozoa), despite the moderate changes in IgM and IgT repertoire

(Front. Immunol. 11:581361, 2020, doi: 10.3389/fimmu.2020.581361)

Chapter 4. Unveiling Enteromyxum leei (Myxozoa) profilactic and diagnostic peptides from RNAseq data

(Unpublished)

Chapter 5. Enterospora nucleophila (Microsporidia) in gilthead sea bream (Sparus aurata): Pathological effects and cellular immune response in natural infections

(Vet Pathol. 57(4):565-576., 2020, doi: 10.1177/0300985820927707)

Chapter 6. Experimental horizontal transmission of Enterospora nucleophila (Microsporea: Enterocytozoonidae) in gilthead sea bream (Sparus aurata)

(Submitted to the Journal 'Animals') 


$$
28
$$


Introduction 


\section{GENERAL ASPECTS}

\section{$1.1 \quad$ Aquaculture}

According to the Food and Agriculture Organization of the United Nations (FAO), "Aquaculture is the farming of aquatic organisms, including fish, molluscs, crustaceans and aquatic plants. Farming implies some form of intervention in the rearing process to enhance production, such as regular stocking, feeding, protection from predators, etc.".

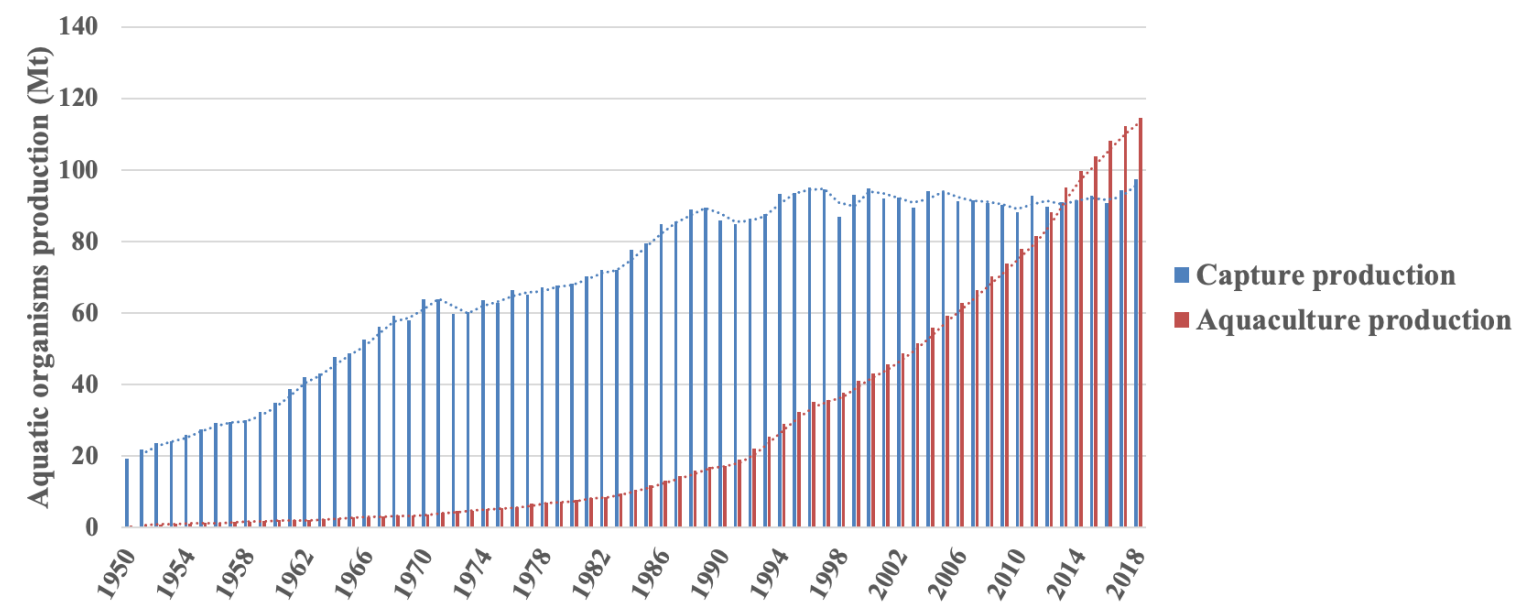

Figure 1. Aquatic organisms production worldwide from aquaculture and capture sources. Abbreviation: Mt, Millions of tonnes. Data from FAO, 2019 (www.fao.org).

Nowadays, due to the high global fish food demand, and being the fish captures a limited and non-sustainable option, aquaculture arises as the best alternative to provide fish for the ballooning human population in the future (Subasinghe et al., 2009). At a global scale, aquaculture production increase has been very fast during the past decades (Figure 1), in parallel to the world population growth. FAO announced recently (2018) that $54.1 \%$ of the aquatic products consumed were provided by aquaculture, and by 2050 we will need to duplicate the actual production to sustain the demand (Stentiford et al., 2017; Waite et al., 2014).

The success of modern aquaculture is based on the increased knowledge of the biology of aquatic species, mainly on feeding and reproduction. However, this success has been hampered by emerging pathogens that proliferate easily in fish farms facilities (Rigos \& Katharios, 2009; Shinn et al., 2015). Fish production creates new environments, increasing fish density and decreasing genetic variability, which have consequences in ecology, epidemiology and evolution of disease aspects (Kennedy et al., 2015; Sundberg et al., 2016). The intensive and massive productions in cages or small fairgrounds, plus the increasing temperatures due to the global warming, act together increasing and facilitating the propagation of infectious diseases in fish farms (Antonio \& Hedrick, 1995; Costello, 2006; Karvonen et al., 
2010; Okamura et al., 2015; Rintamäki-Kinnunen et al., 1997; Yanagida et al., 2006). These infections have become an important problem in cultured fish, affecting animal welfare (Iwanowicz, 2011), through direct mortalities or morbidity, limiting the production (Sindermann, 1987), and causing economical losses for the sector (Meyer, 1991; Monir et al., 2015; Shin et al., 2015; Tavares-Dias \& Martins, 2017). While viral and bacterial diseases have been extensively studied, less attention has been paid to parasitic diseases. In the National Centre for Biotechnology Information (NCBI) database, the amount of research articles found on viral and bacterial diseases in aquaculture is 3.1 and 3.6 times higher, respectively, than that on parasites. Thus, there is a need of research efforts addressed to parasitic infections, since they still remain as a key constraint to sustainable aquaculture production.

\section{2 Gilthead sea bream biology and culture}

Gilthead sea bream, Sparus aurata (Linnaeus, 1758), is the fish species in which this $\mathrm{PhD}$ thesis focuses. It is a marine teleostean fish belonging to the Family Sparidae, within the Order Perciformes. This species is a marine shore fish that lives in both, rocky and seaweed bottoms, but it is also frequently found on sandy grounds. In general, young fish remain at low depth (up to $30 \mathrm{~m}$ ), whereas adults can reach deeper waters (maximum depth of $150 \mathrm{~m}$ ).

Gilthead sea bream is common in the Mediterranean Sea. It is distributed along the Eastern Atlantic coasts from Great Britain to Senegal, and is rare in the Black Sea (FAO, 2019). Due to its euryhaline (tolerance range 3-70 \%o) and eurythermal habits (tolerance range $5^{\circ} \mathrm{C}-33^{\circ} \mathrm{C}$ ), this species is found in both marine and brackish water environments, such as coastal lagoons and estuarine areas, in particular during the initial stages of its life cycle. Hatching occurs in the sea during winter, and fingerlings migrate in early spring to coastal waters, where they can find milder temperatures and greater amounts of food. In late autumn, adults return to the open sea to breed. In general, adults show a solitary behaviour, whereas fry and fingerlings are more gregarious.

Gilthead sea bream is carnivorous and feeds on molluscs, cephalopods and small fish. The largest specimens can reach up to $8 \mathrm{~kg}$ and $70 \mathrm{~cm}$, but in their first year of life they grow up to $350 \mathrm{~g}$. The main physical features of this species are ovoid and laterally compressed body, with a silvery grey colour, and with a golden strip between the eyes (Figure 2). This species is protandrous hermaphrodite, maturing as males during the first one-two years of life $(20-30 \mathrm{~cm})$, and changing to female thereafter $(33-40 \mathrm{~cm})$. 


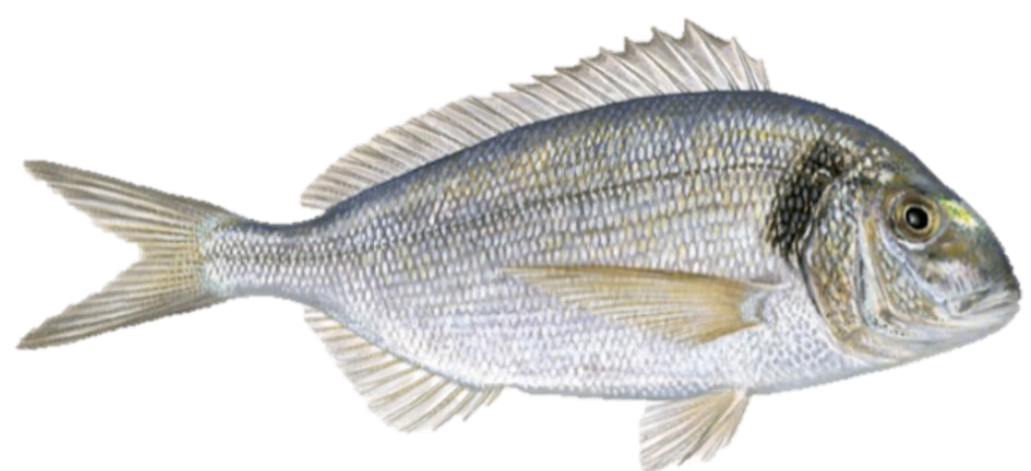

Figure 2. Gilthead sea bream, Sparus aurata (Linnaeus, 1758). From European Commission home webpage (https://ec.europa.eu/info/index_en).

The complete life cycle of gilthead sea bream in captivity was first achieved in Spain, in the 'Planta de Cultivos Marinos' at the Spanish Institute of Oceanography in Lo Pagán (IEO, Murcia, Spain) (Odai et al., 1978; Ortega et al., 1973), and also in France and Italy in the early 80's (Cameron, 2003). The production techniques improved in the subsequent years, and in the 90's fish farms started to produce enough fingerlings to cope with the growing demand (Moretti et al., 1999). At the beginning, the pre-fattening and fattening were performed mainly in swamps in a semintensive- and extensive way. Progressively, the intensification of the cultures increased, and new facilities for inland intensive culture were developed.

Gilthead sea bream is mainly cultured in the Mediterranean Sea, although it is also produced in the Red Sea, Black Sea, the Persian Gulf and the Arabian Sea. The latest updates from FAO (2018) estimate the global gilthead sea bream production on 237 $\mathrm{kt}$ in 2018, and almost the 80\% (182 kt) is concentrated in European and Asiatic countries. Among the European countries, Greece is the largest producer $(57.8 \%)$, followed by Spain (18.8\%) and Italy (8.9\%). Globally, the two major producers are Turkey and Greece, representing 35.6\% and 23.9\% of the worldwide production of $S$. aurata. Figure 3 summarizes the production in tonnes of gilthead sea bream (FAO, 2018). 


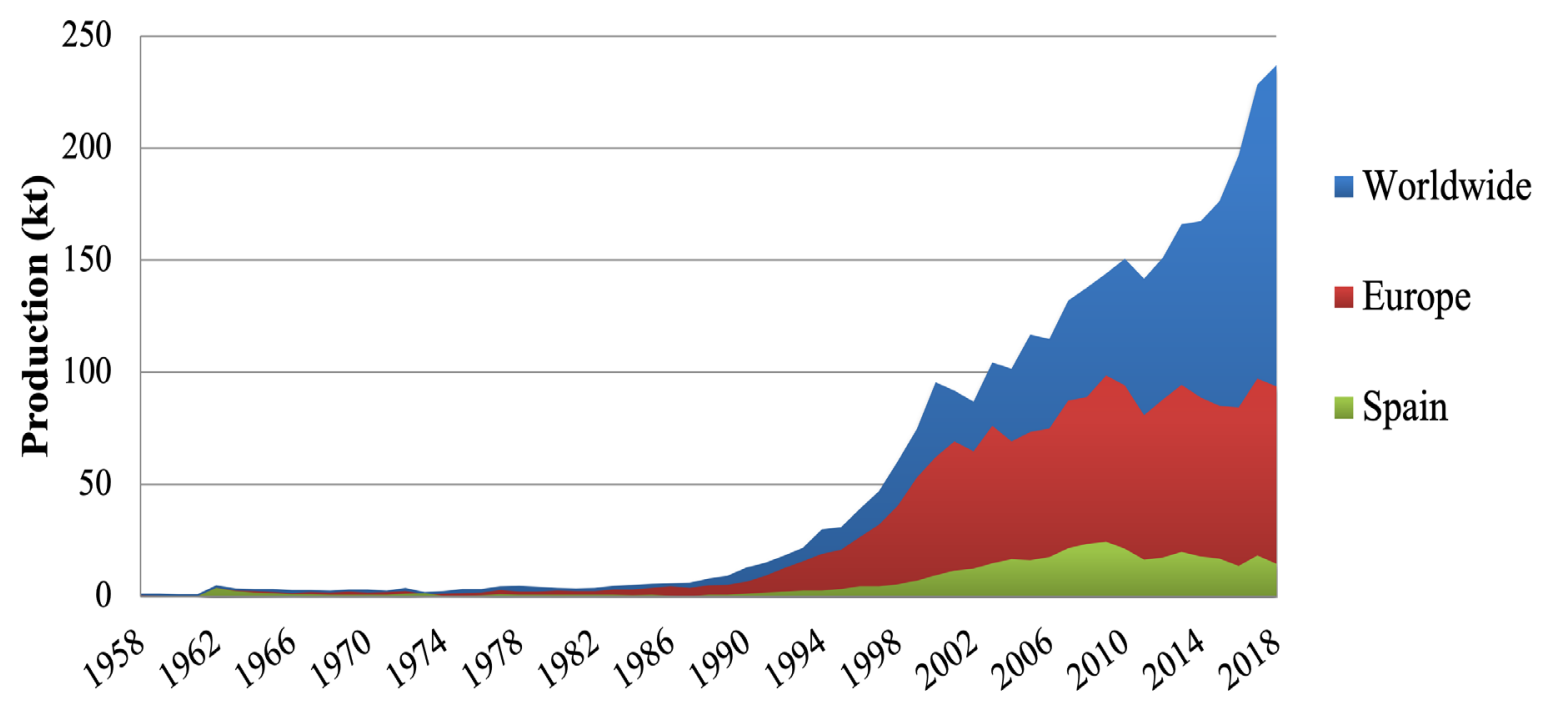

Figure 3. Production of gilthead sea bream in Spain, Europe and worldwide from 1958 onwards. Abbreviation: $\mathrm{kt}$, thousands of tonnes. (Data from FAO, 2019).

\section{3 Parasitic diseases in cultured gilthead sea bream}

Several parasitic diseases, with different degrees of importance, have been reported in gilthead sea bream. This fish species is susceptible to ectoparasites affecting gills and/or skin and endoparasites affecting several internal organs. Among the ectoparasites, ciliates such as Trichodina spp. affecting gills and skin (ÁlvarezPellitero et al., 1995), or Scuticociliates in wounds, gills and mouth cavity (Fioravanti et al., 2006) can be found, and also flagellates like Amylodinium ocellatum (Paperna, 1980) in gills and skin, and plathelminths like Sparicotyle chrysophrii in gills (Faisal \& Imam, 1990), and crustaceans such as Ceratothoa oestroides and C. parallela (Mladineo, 2003; Papapanagiotou \& Trilles, 2001). Endoparasites include mainly four different clades Platyhelmintha, Myxozoa, Microsporidia and Apicomplexa (Table 1). 
Table 1. Main endoparasites described in farmed gilthead sea bream. Abbreviations: gills (Gi), skin (Sk), kidney $(\mathrm{Kd})$, muscle $(\mathrm{Mu})$, intestine (Int), stomach (Sto), systemic (Syst), blood vessels (Bv), gall bladder (Gb).

\begin{tabular}{l|l|l|l} 
Parasite group & Species & $\begin{array}{l}\text { Affected } \\
\text { tissue }\end{array}$ & Reference \\
\hline Platyhelmintha & Cardiola aurata (Digenea) & Bv, Gi, Kd & Holzer et al., 2008; Padrós et al., 2001a \\
\hline \multirow{2}{*}{ Myxozoa } & Ceratomyxa sparusaurati & Gb, Int & $\begin{array}{l}\text { Sitjà-Bobadilla \& Álvarez-Pellitero, } \\
1995\end{array}$ \\
\cline { 2 - 4 } & Enteromyxum leei & Int & Diamant et al., 1994 \\
\cline { 2 - 4 } & Henneguya sp. & Gi, Heart & Caffara et al., 2003 \\
\cline { 2 - 4 } & Kudoa iwatai & Syst & Diamant et al., 2005 \\
\cline { 2 - 4 } & Leptotheca sparidarum & Kd & $\begin{array}{l}\text { Sitjà-Bobadilla \& Álvarez-Pellitero, } \\
\text { 2001 }\end{array}$ \\
\cline { 2 - 4 } & Sphaerospora sparis & Kd & $\begin{array}{l}\text { Sitjà-Bobadilla \& Álvarez-Pellitero, } \\
1995\end{array}$ \\
\hline \multirow{2}{*}{ Microsporidia } & Pleistophora sp. & Mu & $\begin{array}{l}\text { Abela et al., 1996; Athanassopoulou, } \\
1998\end{array}$ \\
\cline { 2 - 4 } & Glugea sp. & Mu, Int, Sk & Mathieu-Daude et al., 1992 \\
\cline { 2 - 4 } & Enterospora nucleophila & Int & Palenzuela et al., 2014 \\
\hline \multirow{2}{*}{ Apicomplexa } & Cryptosporidium molnari & Sto, Int & $\begin{array}{l}\text { Álvarez-Pellitero \& Sitjà-Bobadilla, } \\
\text { 2002 }\end{array}$ \\
\cline { 2 - 4 } & Eimeria sparis & Int & Sitjà-Bobadilla et al., 1996 \\
\cline { 2 - 4 } & Goussia sparis & Int & Sitjà-Bobadilla et al., 1996
\end{tabular}

Parasites enclose protozoan and metazoan living organisms. For metazoans, the fact of being phylogenetically closer to their hosts hinders the selection of specific therapeutic, diagnostic and vaccination targets. Besides, for histozoic parasites (embedded in the tissue), efficient separation for axenic in vitro culture is barely possible. For these reasons, there are few effective treatments against parasites in aquaculture and their isolation and culture are not possible for most of the parasites. Consequently, prevention through cleaning and disinfection of rearing facilities, plus continuous surveillance and vigilance plans for early diagnosis, are thus far the best solutions to reduce negative effects. This $\mathrm{PhD}$ thesis focuses on two metazoan parasites that threaten gilthead sea bream aquaculture, the myxozoan Enteromyxum leei and the microsporidian Enterospora nucleophila. 


\section{MYXOZOA}

\subsection{General aspects}

For over 150 years, myxozoans were regarded as protozoans due to the initial descriptions based on their small size, morphological simplicity, and multicellular spores with cnidocyst-like polar capsules (Feist \& Longshaw, 2006; Kent et al., 2001). Later, the reassessment of myxozoan ultrastructure, spore morphology and the advent of DNA sequence analyses supported the inclusion of the Myxozoa as metazoans. Recent discoveries of cnidarian-specific minicollagen genes, prompted the rearrangement of Myxozoa as an independent subphylum, and supported its inclusion in the phylum Cnidaria (Atkinson et al., 2018).

Myxozoans infect mainly fish, however, other aquatic-associated vertebrates such as turtles, waterfowl and amphibians, as well as terrestrial insectivorous mammals, have also been reported as hosts (Bartholomew et al., 2008; Eiras, 2005; Friedrich et al., 2000). Some myxozoan infections are innocuous or have a little impact on their hosts. However, some species can cause important economic losses in fish farms and aquaculture (Diamant et al., 1994; Hyatt et al., 2018; Kristmundsson \& Freeman, 2014; Quiroga et al., 2006). Myxozoans have multicellular spores, composed by polar capsules, valves, and sporoplasms that are the infective cells (Figure 4). The number of all these three cell types and the morphology of the spores is the basis of the classical taxonomy for these species (Fiala et al., 2015).
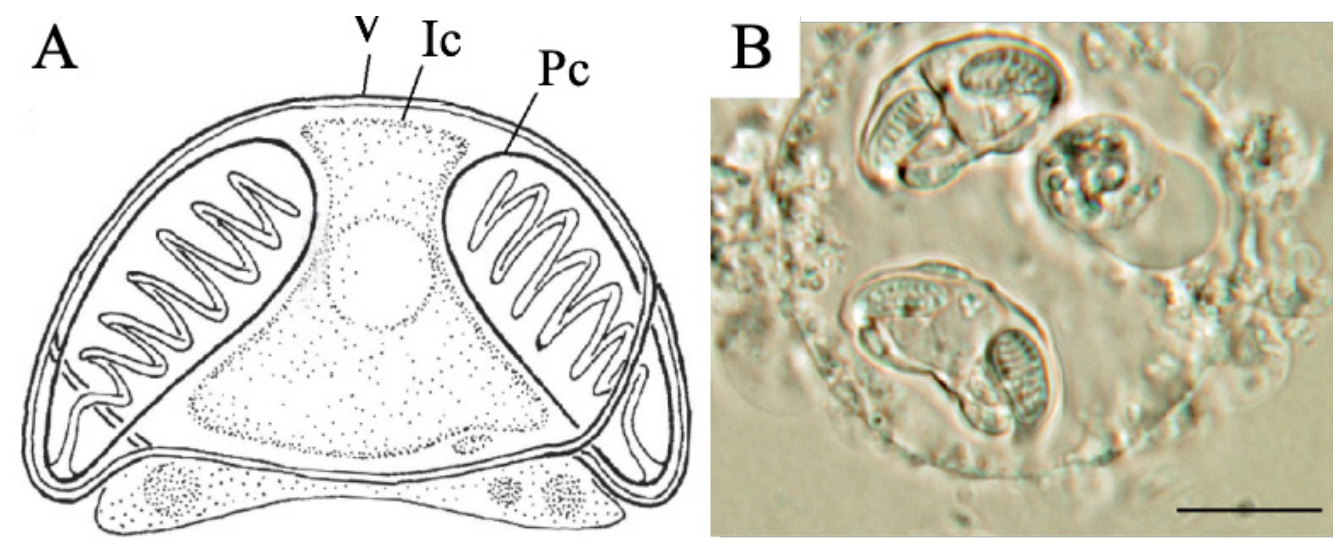

Figure 4. Enteromyxum leei spores. A) Scheme of a myxospore. Abbreviations: V, valves; Ic, infective cell; Pc, polar capsule (Adaptation from Diamant et al., 1994). B) Disporous sporoblast holding two immature myxospores and an accompanying cell in a fresh smear of posterior intestine. Scale bar $=10 \mu \mathrm{m}$ (Adaptation from Estensoro, 2013). 
The extreme reduction of body plans from free-living cnidarians and their small genomes were associated to an evolutionary transition to parasitism (Chang et al., 2015). Due to their parasitic lifestyle, they lack several metazoan's features such as true gametes, embryogenesis, epithelial structures, a nervous system, gut, cilia and centrioles (Chang et al., 2015; Lom \& Dyková, 2006). Myxozoan taxonomy is mostly based on the morphology of the spores (Figure 4) and also, to some extent, on the type of trophic stages (i. e. plasmodia, pseudoplasmodia, sacs, or myxoworms), tissue specificity, and host group preference (Fiala et al., 2015). Nowadays, this group encompasses over 2700 species, mostly endoparasites (Canning \& Okamura, 2004), gathered in two Classes: Malacosporea and Myxosporea (Canning et al., 2000).

\subsection{Malacosporea}

The Class Malacosporea is constituted by two genera: Tetracapsuloides and Buddenbrockia (Tops et al., 2005). The life cycle of Malacosporeans involves a freshwater bryozoan as a definitive host, and a fish as intermediate host (Fiala et al., 2015) (Figure 5). Development in bryozoans results in the formation of spherical to ovoid sacs or elongated active worm-like stages that, unlike Myxosporeans, show tissue level organisation. Proliferative and trophic stages dwell inside the bryozoan body cavity. During the proliferative stage, upon completion of meiosis, spherical and mature malacospores develop. Bryozoan malacospores consist of eight soft shell valves encasing four polar capsules and two sporoplasms with secondary cells inside. In contact with fish gills or skin, sporoplasms leave the spore valves and penetrate in the host (Grabner \& El-Matbouli, 2010). Once the parasite reaches the fish kidney, the target organ, sporogony develops in the interstitium or tubule lamina, where subspherical fish malacospores of four soft shell valves, two polar capsules and just one sporoplasm are formed (Hedrick et al., 2004). The diversity of Malacosporean species might be much greater than is known so far, especially considering that freshwater bryozoans, their definitive hosts, are globally distributed (Massard \& Geimer, 2008). The scarce information about Malacosporean species is attributed to their little effect on the fish host and the difficulties for their detection (Feist \& Longshaw, 2006). 


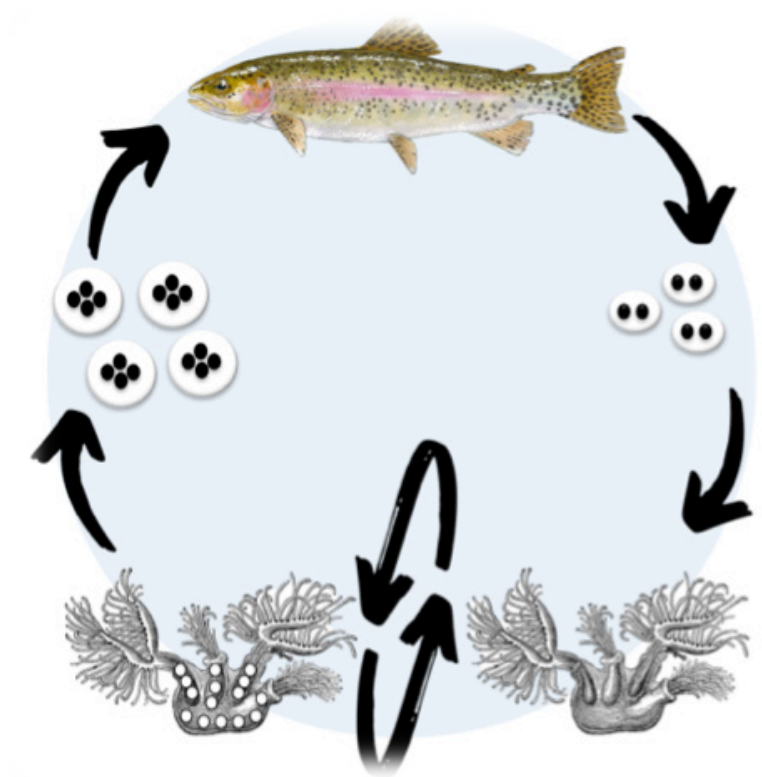

Figure 5. Malacosporean life cycle. Tetracapsuloides bryosalmonae parasite of rainbow trout (Oncorhynchus mykiss) as intermediate fish host, and a freshwater bryozoan (Fredericella sultana) as invertebrate definitive host.

The most well-known disease caused by malacosporeans is the proliferative kidney disease (PKD) affecting salmonids, caused by Tetracapsuloides bryosalmonae (Canning et al., 2000; Kent, 1986). This is one of the few myxozoan parasites whose entire life cycle is known (Figure 5). Due to the economic importance of the host, $T$. bryosalmonae biology and host-parasite interactions have been extensively studied (Abd-Elfattah et al., 2014a; Abd-Elfattah et al., 2014b; Bailey et al., 2020; Fontes et al., 2017; Grabner \& El-Matbouli, 2008; Kumar et al., 2013).

\subsection{Myxosporea}

Most myxozoans belong to the Class Myxosporea, affecting mainly freshwater and marine fish. Alternation of hosts is also common in myxosporean life cycles (Okamura et al., 2015), consisting of an actinospore phase and a myxospore phase. The actinospore phase, which occurs inside an oligochaete or polychaete annelid depending on the environment (freshwater or marine, respectively), is where sexual processes occur and result in actinospores production. The myxospore phase occurs within a fish as intermediate host, and consists of the asexual reproduction and myxospores production (Feist et al., 2015). However, the complete life cycle has been described mostly for fresh water fish species (Eszterbauer et al., 2015), like Myxobolus cerebralis (Wolf \& Markiw, 1986), Ceratonova shasta (Bartholomew et al., 1997), or Hoferellus carassii (El-Matbouli et al., 1992; Trouillier et al., 1996). It must be noted that not having found the invertebrate host does not mean that it does not exist and there are many myxozoan types known only for their myxospore or actinospore phases (Atkinson et al., 2018) 


\section{$2.4 \quad$ Enteromyxum leei}

Enteromyxum leei is an enteric myxosporean parasite that affects a wide range of fish species due to its low host specificity. In fact, it is one of the most devastating pathogens in warm water marine aquaculture because of the broad range of susceptible fish. This myxozoan has been described thus far in more than 60 fish species, belonging to different fish orders (Yokoyama, 2012). Among farmed species, $E$. leei has been found in perciforms, such as gilthead sea bream (Sparus aurata) (Padrós et al., 2001b; Yanagida et al., 2004), red sea bream (Pagrus major) (Yanagida et al., 2008), red porgy (Pagrus pagrus) (Diamant et al., 1995), blackspot sea bream (Pagellus bogavareo) (Marino et al., 2004), sharpsnout sea bream (Diplodus puntazzo) (Le Breton \& Marques, 1995), white sea bream (Diplodus sargus) (Golomazou et al., 2006), common dentex (Dentex dentex) (Tsioli, p.c. 1997), malabar grouper (Epinephelus malabaricus) (China et al., 2013), or in pleuronectiforms such as olive flounder (Paralichthys olivaceus) (Sekiya et al., 2016), or in tetraodontiforms as tiger puffer (Takifugu rubripes) (Yanagida et al., 2006). The severity of the infection depends on the susceptibility of the fish host. In susceptible species, such as $D$. puntazzo, S. aurata, E. malabaricus and T. rubripes, this parasite causes myxozoan emaciation disease resulting in outbreaks and significant financial losses within Mediterranean, Red Sea, and Asian aquaculture industries (Álvarez-Pellitero et al., 2008; China et al., 2014; Diamant et al., 1994; Ogawa \& Yokoyama, 2001; Rigos et al., 1999, ).

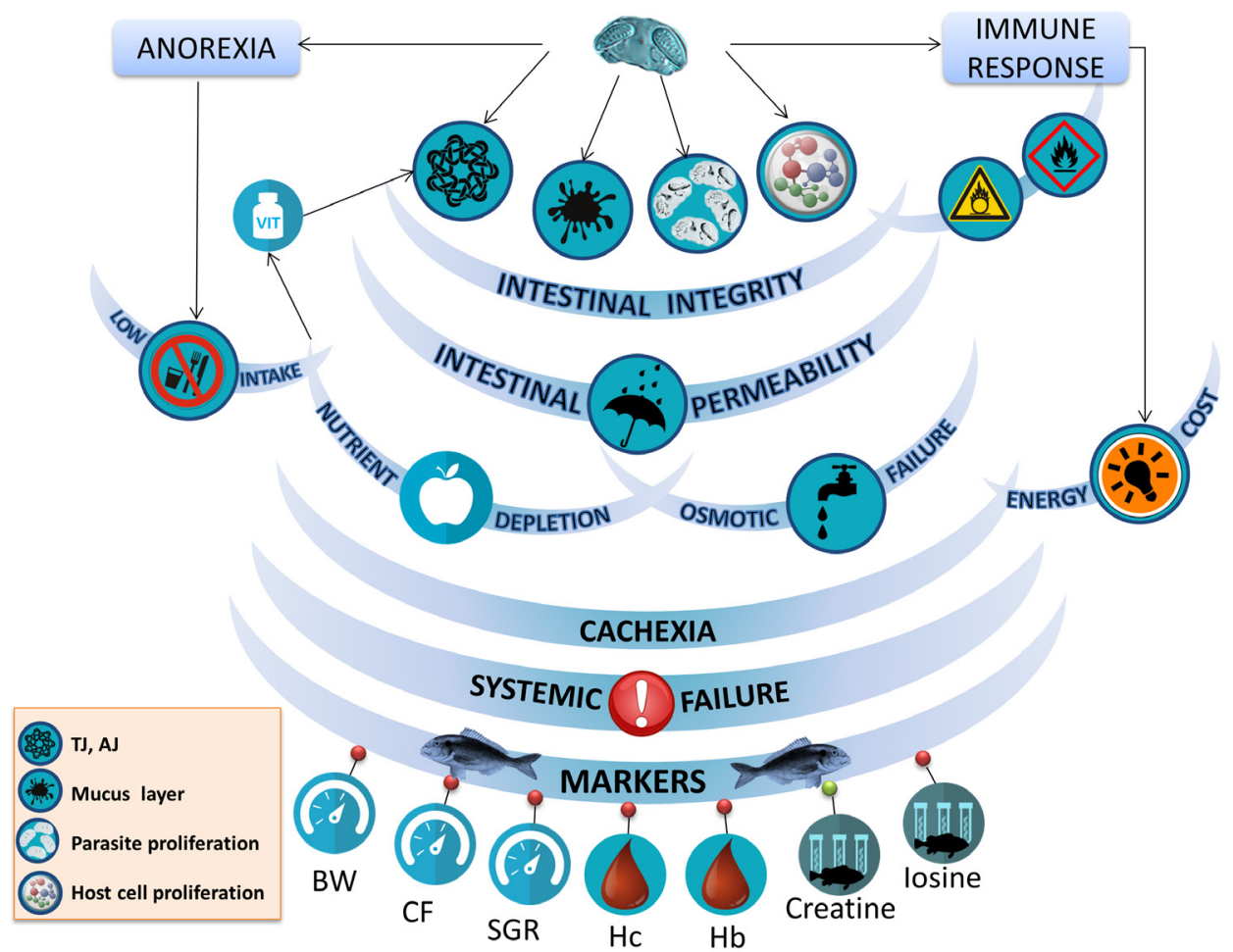

Figure 6. Disease mechanism for Enteromyxum leei in gilthead sea bream. After Sitjà-Bobadilla et al., 2019. Abbreviations: TJ, tight junctions; AJ, adherens junctions; BW, body weight; CF, condition factor; SGR, specific growth rate; Hc, hematocrit; Hb, hemoglobin. 
In gilthead sea bream, this parasiteproduces a slow-progressing disease, which induces weight loss, poor food conversion rates, delayed growth, reduced marketability, anorexia, cachexia (Sitjà-Bobadilla et al., 2008, 2019), and eventually death (rates up to 20\%) (Palenzuela, 2006; Rigos \& Katharios, 2009) (Figure 6). Moreover, its impact is further enhanced due to its direct fish-to-fish transmission (Sitjà-Bobadilla et al., 2007). The most evident clinical sign is the severe emaciation, which entails the typical knife-shape, sometimes accompanied by a distended abdomen with accumulation of ascitic fluid and bile. The infection is mostly restricted to the intestinal area, following a particular pattern, infecting first the posterior intestine, then spreading to the anterior intestine and pyloric caeca, and finally colonizing the middle intestine (Estensoro et al., 2010; Fleurance et al., 2008; Sitjà-Bobadilla \& Palenzuela, 2012). At early stage infections, the parasite presents a patchy distribution in localized loci (Estensoro et al., 2010). In very advanced stages, the parasite can also be found in urinary bladder (Diamant et al., 1994), gallbladder epithelium, in intra-hepatic biliary ducts and the gastric lumen (Fleurance et al., 2008), and more frequently in gallbladder or intestinal lumina together with host cell debris from epithelial sloughing (Cuadrado et al., 2008). Macroscopically, infected intestines appear fragile with semi-transparent walls, focal congestion and luminal mucous liquid. The histopathology associated involves an intestinal epithelia disorganized and invaded by parasite stages, leading to the desquamation of the epithelial layer, and resulting in the disruption of the epithelial layer and impairment of the absorptive intestinal function (Sitjà-Bobadilla et al., 2019) (Figure 7). 


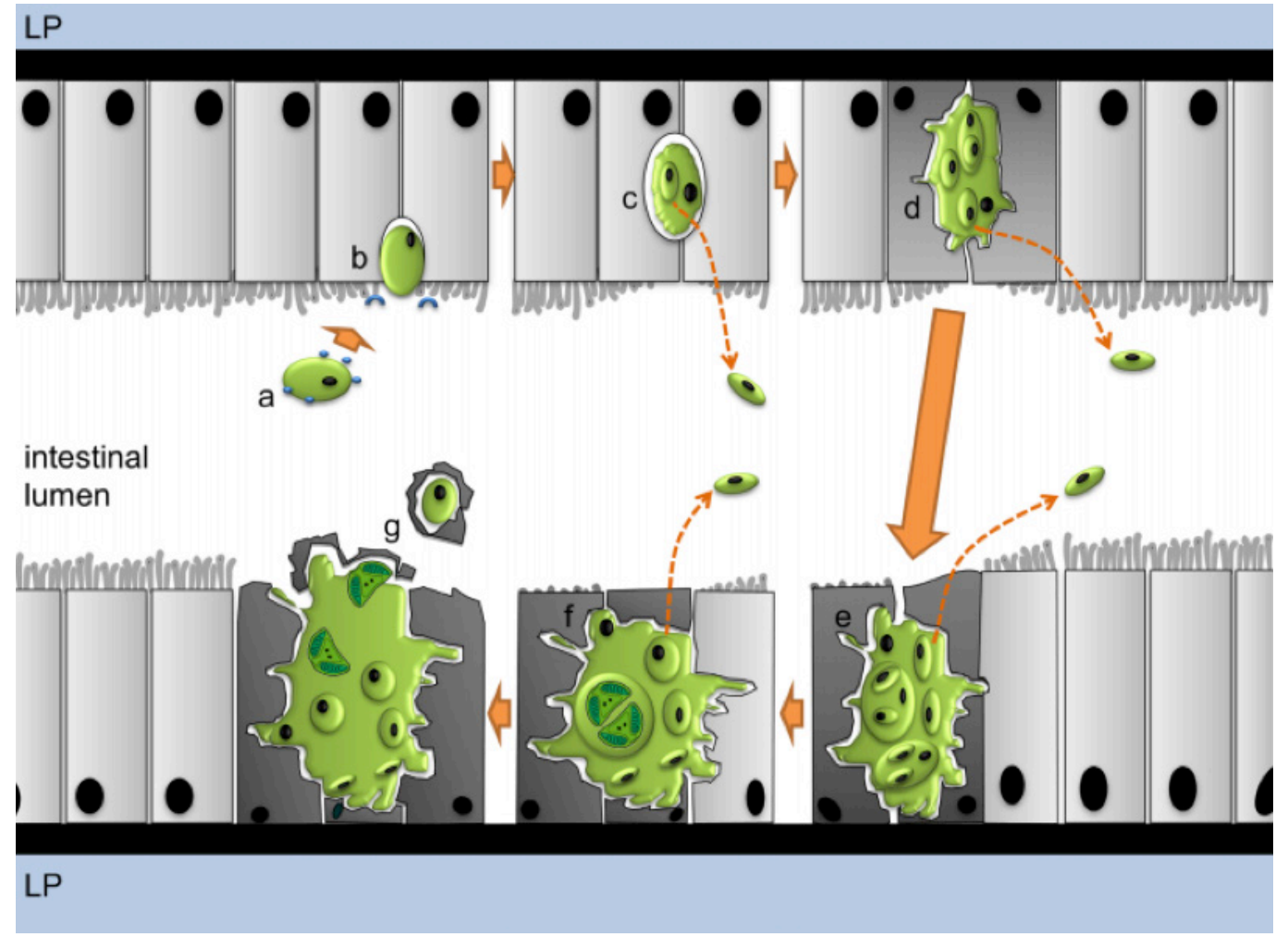

Figure 7. Hypothetical intestinal invasion mechanism of Enteromyxum leei in gilthead sea bream. Parasite cells are represented in green and host enterocytes in grey. Bold arrows indicate the chronologic growth of the parasite, while dashed arrows indicate the generation of free secondary cells ready to colonize new intestinal areas of the same or of other fish. A luminal parasite stage carrying certain antigenic determinants (a) recognizes and adheres to specific receptors (like lectins, mucins, glycans, etc.) at the epithelial surface. The parasite penetrates the epithelium through the paracellular space between enterocytes (b). The irregular parasite surface (c) projects cytoplasmatic protrusions into the neighbouring enterocytes (d) displacing their cytoplasms and nuclei while it grows. Affected enterocytes contacting the parasite increase in number, lose their apical microvilli and start to necrotize (darker colour) (e-f). Eventually, enterocytes are disrupted by the parasite which liberates into the lumen desquamated stages still bound to epithelial host material (g). LP = lamina propria-submucosa. Adaptation from Sitjà-Bobadilla \& Palenzuela, 2012. 
Table 2. Fish-to-fish infection trials with Enteromyxum spp. (Eszterbauer et al., 2015).

\begin{tabular}{|c|c|c|c|c|}
\hline $\begin{array}{l}\text { Parasite } \\
\text { species } \\
\end{array}$ & \begin{tabular}{|l|l}
$\begin{array}{l}\text { Mode of } \\
\text { infection }\end{array}$ \\
\end{tabular} & Donor fish & Recipient fish & References \\
\hline \multirow[t]{10}{*}{$\begin{array}{l}\text { Enteromyxum } \\
\text { leei }\end{array}$} & Feeding & Sparus aurata & Sparus aurata & $\begin{array}{l}\text { Diamant et al., 1994; Sitjà- } \\
\text { Bobadilla et al., } 2007\end{array}$ \\
\hline & Feeding & $\begin{array}{l}\text { Takifugu } \\
\text { rubripes }\end{array}$ & $\begin{array}{l}\text { Takifugu } \\
\text { rubripes }\end{array}$ & Yasuda et al., 2002 \\
\hline & Feeding & Sparus aurata & $\begin{array}{l}\text { Oreochromis } \\
\text { mossambicus }\end{array}$ & Diamant et al., 2006 \\
\hline & Feeding & Sparus aurata & Danio rerio & Diamant et al., 2006 \\
\hline & Oral intubation & Sparus aurata & Sparus aurata & Estensoro et al., 2010 \\
\hline & Anal intubation & Sparus aurata & Sparus aurata & Estensoro et al., 2010 \\
\hline & Cohabitation & Sparus aurata & $\begin{array}{l}\text { Dipplodus } \\
\text { puntazzo }\end{array}$ & Álvarez-Pellitero et al., 2008 \\
\hline & Cohabitation & $\begin{array}{l}\text { Takifugu } \\
\text { rubripes }\end{array}$ & Pagrus major & Yanagida et al., 2008 \\
\hline & Cohabitation & Sparus aurata & Sparus aurata & $\begin{array}{l}\text { Diamant et al., 1994; Sitjà- } \\
\text { Bobadilla et al., } 2007\end{array}$ \\
\hline & Effluent & Sparus aurata & Sparus aurata & $\begin{array}{l}\text { Diamant et al., 1994; Sitjà- } \\
\text { Bobadilla et al., } 2007\end{array}$ \\
\hline \multirow[t]{3}{*}{$\begin{array}{l}\text { Enteromyxum } \\
\text { scophthalmi }\end{array}$} & Feeding & $\begin{array}{l}\text { Scophthalmus } \\
\text { maximus }\end{array}$ & $\begin{array}{l}\text { Scophthalmus } \\
\text { maximus }\end{array}$ & $\begin{array}{l}\text { Redondo et al.,2004; Redondo } \\
\text { et al., } 2002\end{array}$ \\
\hline & Cohabitation & $\begin{array}{l}\text { Scophthalmus } \\
\text { maximus }\end{array}$ & $\begin{array}{l}\text { Scophthalmus } \\
\text { maximus }\end{array}$ & $\begin{array}{l}\text { Redondo et al., 2004; Redondo } \\
\text { et al., } 2002\end{array}$ \\
\hline & Effluent & $\begin{array}{l}\text { Scophthalmus } \\
\text { maximus }\end{array}$ & $\begin{array}{l}\text { Scophthalmus } \\
\text { maximus }\end{array}$ & $\begin{array}{l}\text { Redondo et al., 2004; Redondo } \\
\text { et al., } 2002\end{array}$ \\
\hline \multirow[t]{3}{*}{$\begin{array}{l}\text { Enteromyxum } \\
\text { fugu }\end{array}$} & Feeding & $\begin{array}{l}\text { Takifugu } \\
\text { rubripes }\end{array}$ & $\begin{array}{l}\text { Takifugu } \\
\text { rubripes }\end{array}$ & Yasuda et al., 2002, 2005 \\
\hline & Effluent & $\begin{array}{l}\text { Takifugu } \\
\text { rubripes }\end{array}$ & $\begin{array}{l}\text { Takifugu } \\
\text { rubripes }\end{array}$ & Yasuda et al., 2002, 2005 \\
\hline & Effluent & $\begin{array}{l}\text { Takifugu } \\
\text { rubripes }\end{array}$ & $\begin{array}{l}\text { Pagrus } \\
\text { major }\end{array}$ & $\begin{array}{l}\text { Yanagida et al., 2008; } \\
\text { Yanagida et al., } 2004\end{array}$ \\
\hline
\end{tabular}

E. leeilife cycle is far from being elucidated; it is supposed to have a putative definitive host, probably a polychaete (Figure 8). Rangel et al. (2011) found an actinospore infecting the marine polychaete Diopatra neapolitana in the Aveiro Estuary (Portugal) with a $81 \%$ similarity with E. leei at the SSU rDNA comparison. In spite of this, species in the genus Enteromyxum have a unique direct transmission way, not described for any other myxozoan, which does not involve any intermediate host. This fish-to-fish transmission in Enteromyxum spp. has been described for several hosts, and may occur naturally through cohabitation or water effluent, or by ingestion of infected faeces or intestinal tissue. Table 2 shows examples of 
horizontal transmission routes experimentally achieved for Enteromyxum species (Eszterbauer et al., 2015). In gilthead sea bream, transmission of E. leei has been achieved by different routes: effluent/cohabitation (Diamant \& Wajsbrot, 1997; Estensoro et al., 2010; Sitjà-Bobadilla et al., 2007), and anal or oral intubation or feeding with intestinal scrapings from infected fish (Diamant et al., 1994; Estensoro et al., 2010). In addition to transmission among gilthead sea bream, interspecific transmission has also been described, e. g. infection of D. puntazzo by cohabitation with infected S. aurata (Álvarez-Pellitero et al., 2008), or infection of Puntius tetrazona, Oreochromis mossambicus, Astronotus ocellatus, and Danio rerio by feeding with intestinal scrapings from infected S. aurata (Diamant et al., 2006).

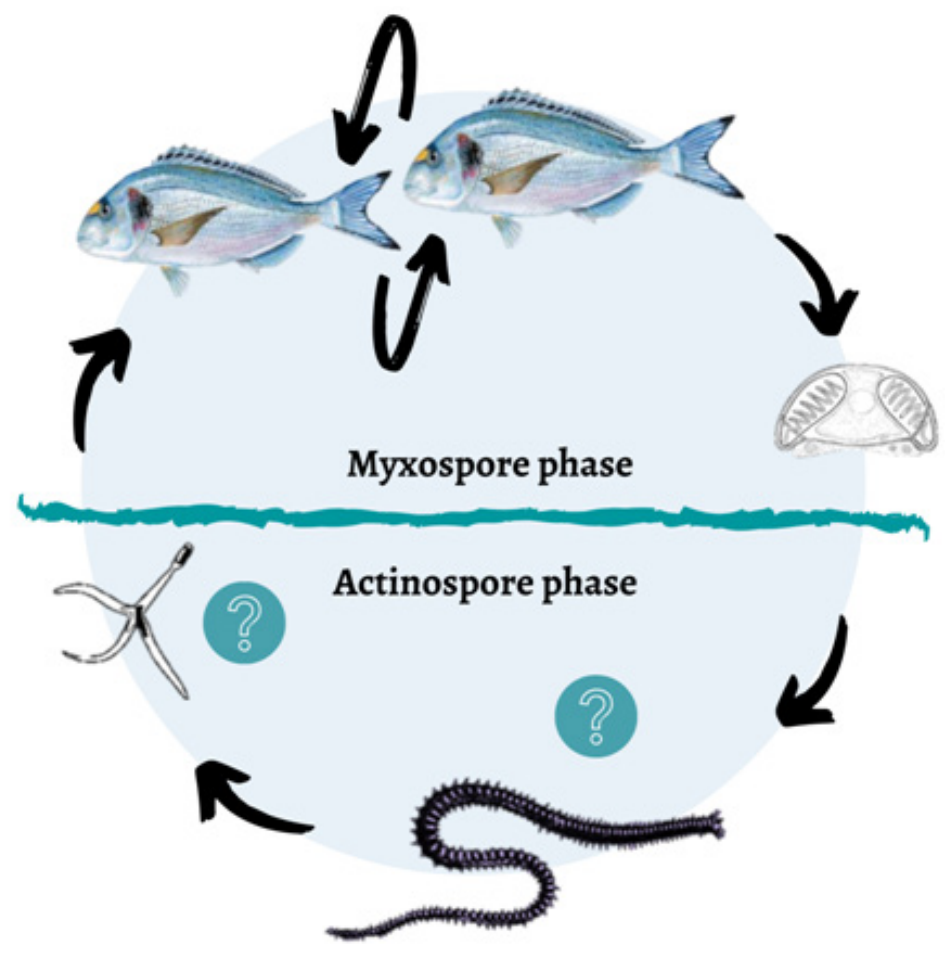

Figure 8. Enteromyxum leei life cycle. The definitive host (polychaete), and the morphology of actinospores remain unknown (question mark).

Inside the fish, proliferative and sporogonic development occurs among the enterocytes, occupying the paracellular space in the intestinal epithelium. In Figure 7, the hypothetical invasion mechanism of E. leei is summarised. During the proliferative development, trophozoites develop secondary (S) and tertiary (T) cells endogenously by the typical myxozoan 'cell-into-cell' division pattern (Sitjà-Bobadilla \& Palenzuela, 2012). E. leei propagates invading new areas through trophozoites and free proliferative stages released from sporogonic stages (or pseudoplasmodia). In early stages of infection, trophozoites are the main stages found. In advanced infections, sporoblasts and free spores together with trophozoites coexist. Spores in Enteromyxum spp. develop in disporous 
pseudoplasmodia, and are crescent-shaped, with two elongated polar capsules located at the spore pointed ends, and one binucleated sporoplasm (infective cell, Figure 4B) (Álvarez-Pellitero et al., 2008; Diamant et al., 1994).

\section{MICROSPORIDIA}

\subsection{General aspects}

Microsporidia are eukaryotic and unicellular organisms, living as obligate intracellular parasites in a variety of hosts, from invertebrates to humans (Caliet al., 2017; Stentiford et al., 2013; Vávra \& Ronny Larsson, 2014). Genetic evidence places them as a cohesive clade (Han \& Weiss, 2017; Vossbrink \& Debrunner-Vossbrink, 2005), closely related to fungi (Capella-Gutiérrez et al., 2012; Han \& Weiss, 2017).

Microsporidians are a serious threat in aquaculture mainly due to the fact that most of them can be horizontally transmitted, without the need of an intermediate host to complete its life cycle (Kent et al., 2014). Effects brought by microsporidians typically range from asymptomatic infections to loose of marketability by liquefaction of muscle tissues (Pulsford \& Matthews, 1991; Sanders et al., 2010). In aquaculture, different species can cause mortality or indirect losses produced by starvation and reduced growth rates (Figueras et al., 1992; Matthews \& Matthews,1980; Palenzuela et al., 2014).

Generally, microsporidian's life cycle consists of three phases (Figure 9): infective, proliferative, and sporogonic. The infective phase is the only extracellular part of the cycle. In proliferative and sporogonic phases, parasite vegetative stages proliferate (multiplication), and develop spores (sporulation). In most microsporidia, two sequences of reproduction follow each other: an initial vegetative reproduction (merogony) yielding daughter cells (merozoites) with the potential either to repeat merogony or to enter the second reproductive phase, the production of spores (sporogony) (Vávra \& Ronny Larsson, 2014). Vegetative stages and spores are very different morphologically. Vegetative stages are cells with primitive characters such as mitosomes, which seem mitochondrial remnants, an unstacked distribution of the Golgi apparatus, and lack the typical microbody-like organelles (peroxisomes) (Cali et al., 2017). Disseminative spores are the only stage able to survive outside of the host cells due to their durability and structural complexity. Spores contain an extrusion apparatus, a stinging coiled filament that allows, during the spore germination, the injection of the spore content to a host cell to perpetuate itself (Cali et al., 2017). 


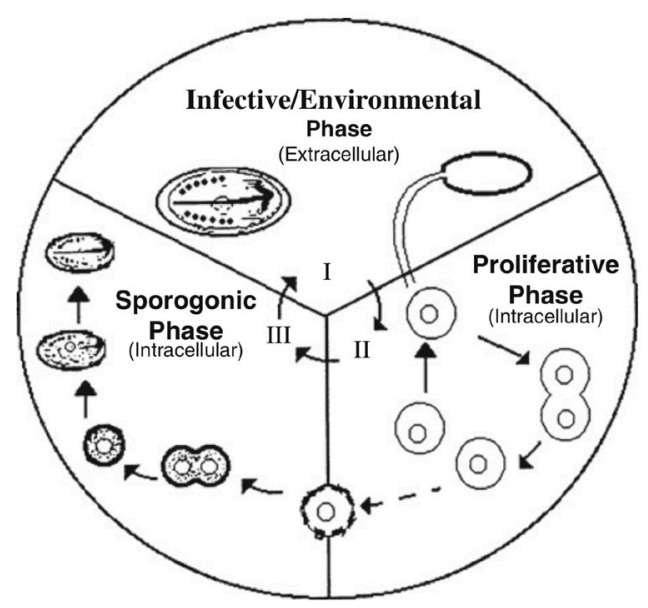

Figure 9. Three typical phases in Microsporidian lifecycle: infective or environmental phase, occur outside the host, and proliferative (multiplicative) and sporogonic phases (maturation of disseminative spores), occur inside the host (Cali et al., 2017).

\subsection{Enterospora nucleophila}

The microsporidian Enterospora nucleophila was first described in Spanish fish farms by Palenzuela et al. (2014). The parasite was detected in gilthead sea bream showing delayed growth (Figure 10), whitish faeces, and trickling mortality, which seemed related with low temperatures in sea cages (Palenzuela et al., 2014). Later on, it has also been detected in Italian and Greek gilthead sea bream farms, and in different facilities including on-growing net cages and land-based gilthead sea bream nurseries (Caffara et al.,2014; Palenzuela \& Sitjà-Bobadilla, unpublished data). E. nucleophila typically infects intestines, having an intranuclear development in rodlet cells and enterocytes, and a cytoplasmic development mainly in enterocytes and macrophages. The intranuclear development of this parasite hinders its in vitro culture and when this $\mathrm{PhD}$ thesis started no experimental transmission protocols were available. Research on this species thus largelly depended on natural outbreaks, which greatly hampers the availability of parasite material for downstream studies.

Phylogenetic studies related E. nucleophila with Enterocytozoon bieneusi, which is considered the most prevalent human microsporidian (Matos et al., 2012), and included it in the family Enterocytozoonidae (Palenzuela et al., 2014; Vossbrinck \& Debrunner-Vossbrinck, 2005). No intermediate host has been described so far for this species and it is assumed that fish-to-fish transmission may occur, like in other microsporidian species: Nucleospora salmonis (Baxa et al., 1992), Loma salmonae (Shaw \& Kent, 1998), Glugea anomala (Weissenberg, 1968). Being an emerging parasite, little is known about E. nucleophila pathology and transmission. 


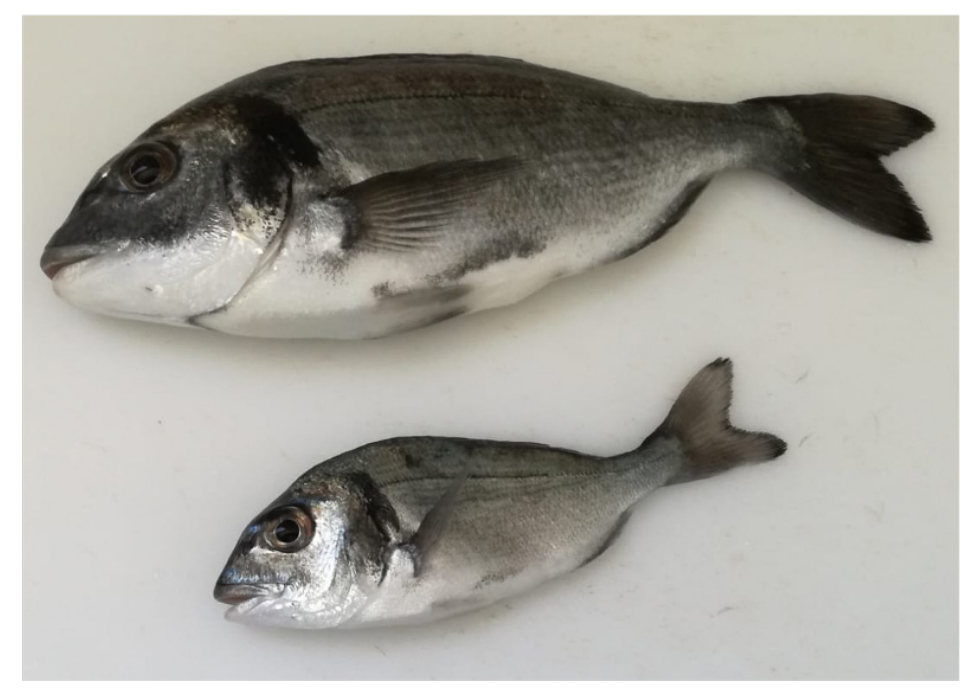

Figure 10. Picture of a heavily infected fish by Enterospora nucleophila (below) compared to a healthy fish from the same stock and maintained under the same conditions.

In heavy infections by E. nucleophila, growth arrestment is remarkable. This is, however, a nonspecific sign, since it can also be caused by inappropriate diets (wrong composition of the feed, feeding regimen, etc.), or enteric pathologies, like those caused by E. leei (Myxozoa) or Cryptosporidium molnari (Coccidia). The clinical signs observed in E. nucleophila, may be consequence of disturbing the normal feed intake, and disrupting intestinal absorption, as determined for other enteric microparasites (Figure 6), though it has not been explored yet.

Diagnosis of E. nucleophila by regular microscopical examination of histological slides (embedded in resin or paraffin blocks) is quite challenging due to its tiny size (spore width is about $1.5 \mu \mathrm{m}$ ) and its intranuclear development. Its detection by microscopical examination requires the highest magnification objective and immersion oil, and can easily pass inadvertent to the not-trained eye. The use of fluorescent brighteners binding to chitin, like calcofluor-white staining, greatly improves the sensitivity for microsporidian detection over routine histological stains. However, just parasitic stages that involve chitin (mature spores) are stained. Finally, in situ hybridization (ISH) with specific probes from SSU rDNA allows the detection of all parasite stages (Ahmed et al., 2019). However, although good for confirmatory diagnosis and advanced research, ISH techniques have low throughput and high cost as a routine diagnostic tool.

In E. nucleophila infection, as in other chronic infections, clinical signs do not appear while the host immune competence keeps an equilibrium with parasite invasion, yielding asymptomatic individuals. For example, the microspordian Nucleospora cyclopteri was detectable by PCR in most organs of apparently healthy lumpfish (Cyclopterus lumpus) (Freeman et al., 2013). This fact has epidemiological 
implications for the spreading of the disease, as early detection of the parasite in asymptomatic fish could be a good prevention method to avoid the spreading of the parasite in the farmed stocks or to avoid stressors that could trigger the clinical condition. In this context, PCR tests are useful tools for research on the infection and assessment of fish stocks condition.

\section{THE IMMUNE SYSTEM OF TELEOST}

All living organisms have mechanisms to defeat pathogens, however, only in metazoan organisms these strategies are known as immune system (Albertset al., 2002). The immune system is composed by cells and humoral compounds that protect animals from the invasion of pathogenic organisms, toxins and other threats, and work on the maintenance of tissue homeostasis and integrity (Sattler, 2017). Those cells are organized into accumulations of diffuse tissues and discretely encapsulated organs in order to perform their functions most effectively, named lymphoid system (Secombes \& Wang, 2012). Typically, this system has been divided in two interconnected subsystems: innate and acquired (Figure 11).

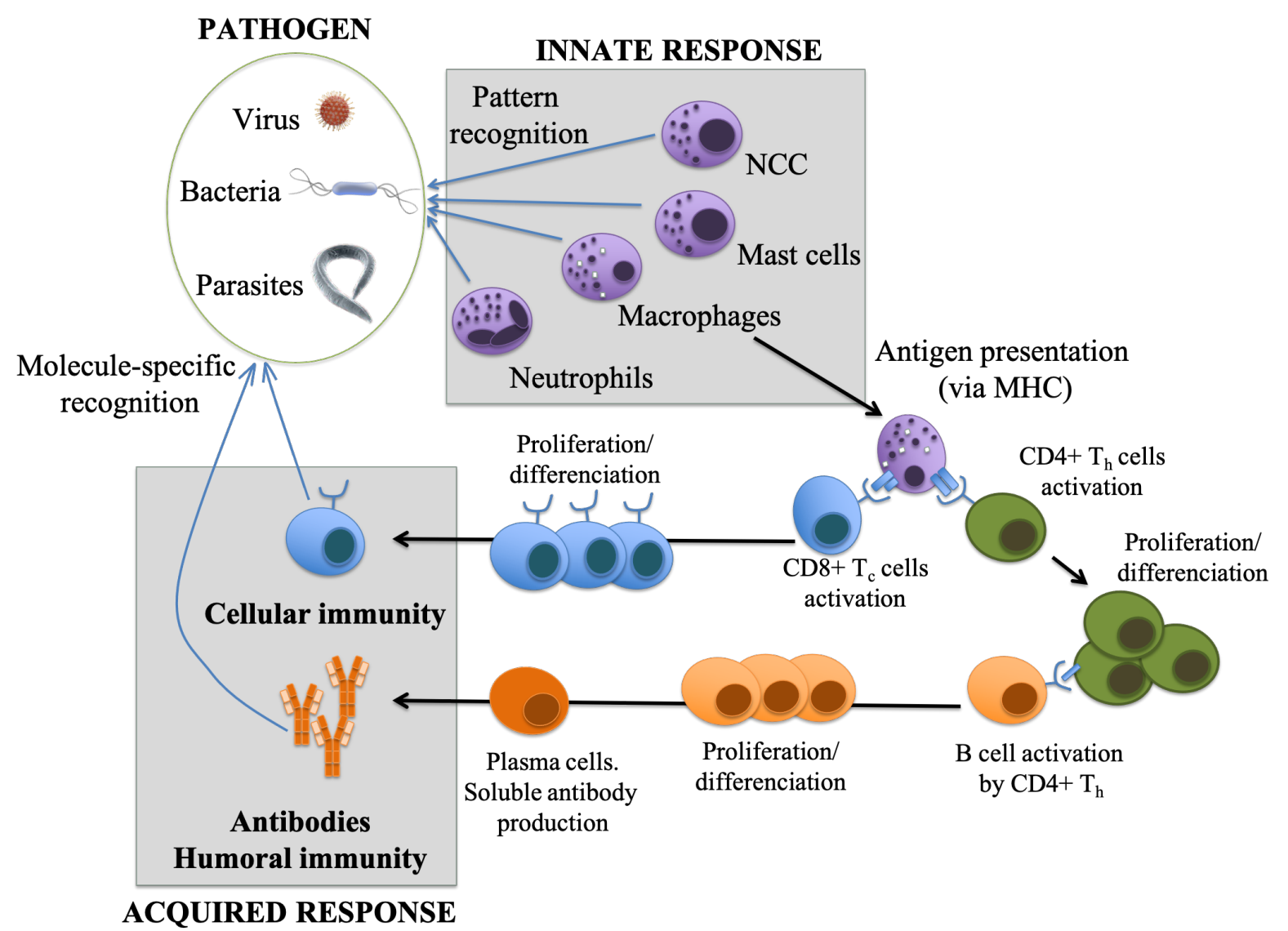

Figure 11. Orchestration of teleost immune response. First line of defense are innate system: macrophages, and granulocytes: mast cells, and non-specific cytotoxic cells (NCC). Followed by adaptive immunity (lymphocytes T and B). Abbreviations: $\mathrm{T}_{\mathrm{C}}$, $\mathrm{T}$ cytotoxic; $\mathrm{T}_{\mathrm{h}}$, $\mathrm{T}$ helper. 
The innate immune system is characterised by a quick response, mediated by germline-encoded pattern recognition receptors or PRR (no specific molecules detected), and by showing no memory against re-exposure to the same pathogen. The acquired immune system depends on the activation of the innate system, hence, it requires more time to be activated, responds to specific molecules, and shows memory (Secombes \& Wang, 2012). Innate responses are evolutionarily older than adaptive responses and thus, elements of innate immune system can be found in all multicellular animals. However, the acquired immune system appeared with the first jawed vertebrates (cartilaginous fishes such as sharks and rays) (Dempsey et al., 2003; Magnadóttir 2006; Tort et al., 2003). Physiological changes of organisms transitioning from water to land (lungs, homoeothermic metabolism, fur, etc.), forced to improve the precision of the immune system (Flajnik, 2018; Tort et al., 2003). The main differences between mammalian and fish immune systems are summarized in Table 3.

The primary lymphoid organs in mammals are thymus, foetal liver and bone marrow (Husband, 2001). In the thymus and bone marrow, lymphocytes mature to functional T and B cells, respectively (Bonilla \& Oettgen, 2010; Cano \& Lopera, 2013). Through this maturation process the individual acquires a broad repertoire of specific antigen receptors, i. e. T cell receptor (TCR) and B cell receptor (BCR) (Bonilla \& Oettgen, 2010; Cano \& Lopera, 2013; Rothenberg et al., 2008). Afterwards, lymphocytes migrate to secondary lymphoid organs, which can be delimited organs like spleen and lymph nodes, or lymphoid tissue associated to mucosa (see 4.1) (Bonilla \& Oettgen, 2010; Secombes \& Wang, 2012). In the germinal centres of secondary organs (GoodJacobson \& Shlomchik, 2010; Secombes \& Wang, 2012) is where the specificity of antibody secreting plasma cells increases and memory B cells are selected, ensuring a prolonged immune protection and rapid recall responses after a first foreign antigen encounter (Gatto \& Brink, 2010).

Several differences in terms of lymphoid activity in organs have been observed in fish. Thymus and head kidney are the two primary lymphoid organs, in which $\mathrm{T}$ and $\mathrm{B}$ cells are produced and mature. In addition, no organized germinal centres are found. However, some studies seem to indicate that melanomacrophage centres (MMC) could be the functional homologs of mammalian germinal centres (Agius \& Roberts, 2003; Secombes \& Wang, 2012). MMCs are formed by groups of melanomacrophages associated with $B$ and $T$ lymphocytes that are found in organs like in kidney, thymus, spleen, and mucosal tissues like gut, gills, or skin (Agius \& Roberts, 2003; Parra et al., 2013). 
Table 3. Main differences between the immune system of jawed fish and mammals. Adaptation from Tort et al., 2003.

\begin{tabular}{|c|c|c|}
\hline & Jawed fish & Mammals \\
\hline \multicolumn{3}{|l|}{ Biotic constrictions } \\
\hline Temperature range & $-2^{\circ} \mathrm{C}$ to $35^{\circ} \mathrm{C}$ & $36.5^{\circ} \mathrm{C}$ to $37.5^{\circ} \mathrm{C}$ \\
\hline Primary environment & Water & Air \\
\hline Metabolism & $\begin{array}{l}\text { Poikilothermia/Endothermia (e. g. bluefin tuna } \\
\text { and some pelagic fishes) }\end{array}$ & Homeothermia \\
\hline External interfaces & Mucous skin, gills & Keratinized skin \\
\hline \multicolumn{3}{|l|}{ Humoral diversity } \\
\hline \multirow[t]{2}{*}{ Igisotypes } & IgM, IgD, IgT/Z (Teleostei) & IgM, IgA, IgD, IgE, IgG \\
\hline & IgM, IgX/IgR, IgW, NAR (C) (Chondrichthyes) & \\
\hline $\begin{array}{l}\text { Ig gene } \\
\text { rearrangement }\end{array}$ & $\begin{array}{l}\text { Multicluster (Chondrichthyes and some } \\
\text { Teleostei) }\end{array}$ & Translocon \\
\hline Non-specific diversity & Several PRR and C3 isoforms (Teleostei) & No C3 isoforms \\
\hline \multicolumn{3}{|l|}{ Overall performance } \\
\hline Antibody affinity & Low & High \\
\hline Antibody response & Slow & Fast \\
\hline Memory response & Weak & Strong \\
\hline Affinity maturation & Low or absent & High \\
\hline Low temperatures & High dependence, immunosupressive response & Low dependence \\
\hline \multicolumn{3}{|l|}{ Lymphoid organs } \\
\hline $\begin{array}{l}\text { Haematopoietic } \\
\text { tissue }\end{array}$ & $\begin{array}{l}\text { Head Kidney (Teleostei) } \\
\text { Epigonal and Leydig organs, meningeal tissue, } \\
\text { orbital and subcranial hematopoietic tissue } \\
\text { (Chondrichthyes) }\end{array}$ & Bone marrow \\
\hline Thymus & $\begin{array}{l}\text { Involution species-dependent, influenced by } \\
\text { seasonal changes and hormonal cycles }\end{array}$ & Involution with age \\
\hline Lymph nodes & Absent & Present \\
\hline $\begin{array}{l}\text { Gut-associated } \\
\text { lymphoid tissues }\end{array}$ & $\begin{array}{l}\text { Not organized, lymphoid aggregates Leydig } \\
\text { organ and spiral valve (Chondrichthyes) }\end{array}$ & $\begin{array}{l}\text { Organized, Peyer } \\
\text { patches }\end{array}$ \\
\hline Germinal centres & $\begin{array}{l}\text { Absent (melanomacrophage centres), dendritic } \\
\text { cells probably present }\end{array}$ & Present \\
\hline
\end{tabular}




\subsection{Lymphoid organs and tissues in teleosts}

Fish mucosal tissues, including skin, gills and gut, constitute the first barrier against pathogen invasion (Lazado \& Caipang, 2014; Salinas, 2015). When this barrier is not enough, and a pathogen penetrates the organism, the network of lymphoid tissues will be activated. Lymphoid tissues consist of a reticular cell framework, which support the humoral and cellular component (migratory and non-migratory) of the innate and acquired immune system, which work closely together.

\section{Mucosa-associated lymphoid tissues}

The mucosa-associated lymphoid tissues (MALT) include the skin (SALT), gills (GIALT), gut (GALT), and nasopharynx (NALT)-associated lymphoid tissues (Salinas, 2015; Secombes \& Wang, 2012). These tissues constitute the first immunological barrier against invasion by pathogens. They are made up of a layer of mucus and an array of specific and non-specific cellular and humoral immune defences. This mucus layer acts not only as a physical barrier but contains also multiple bio-active substances, like mucins or immunoglobulins (Figure 12), complement, C-reactive protein (CRP), lectins, lysozyme, proteolytic enzymes, alkaline phosphatase and esterase, antimicrobial peptides and hemolysine (Álvarez-Pellitero et al., 2008; Brinchmann, 2016; Magnadóttir, 2006). In contrast to mammals, teleost fish do not have organised associated lymphoid tissue, such as the Peyer's patches of the gut (Jung et al., 2010; Mason et al., 2008). Instead, the fish gut contains disorganized populations of leucocytes; including macrophages, lymphocytes, and granulocytes (Secombes \& Wang, 2012).

\section{Head kidney}

The kidney in teleosts is a Y shaped organ located dorsally along the vertebral column. It consists of two lobes in the anterior part, known as head kidney, and the posterior trunk kidney, in which the two lobes are fused. Functionally, these two structures are different. The aglomerular head kidney is mainly lymphohematopoietic and endocrine tissue, whereas, in the posterior glomerular trunk kidney, the excretory function predominates (Deivasigamani, 2007).

Teleost head kidney is functionally related with the bone marrow in mammals (Kum \& Sekkin, 2011; Zapata, 1979) or Bursa of Fabricius in birds (Løken et al., 2019), which are the main lymphohematopoietic organs, holding and differentiating blood cells precursors. At the same time, head kidney also serves as a secondary lymphoid organ, important in the induction and elaboration of the immune response. Supporting this, studies in different fish species described a constant expression of recombination-activating genes (RAG), which are essential in initiating the $\mathrm{V}(\mathrm{D}) \mathrm{J}$ recombination that diversifies the $\mathrm{T}$ - and B-cell repertoire (Huttenhuis et al., 2005; Willett et al., 1997). Structurally, the cellular component of 
the head kidney is scattered within its parenchyma, where lymphohaematopoietic cells are found within a network of fibroblastic reticular cells and sinusoidal blood vessels. Its stroma supports lymphohematopoietic cells, together with innate and adaptive immunity cell components, and unlike higher vertebrates constitutes the principal immune organ responsible for phagocytosis (Dannevig et al., 1994; Galindo-Villegas \& Hosokawa, 2004), antigen processing activity and production of IgM and immune memory through MMCs (Tort et al., 2003).

\section{Thymus}

The thymus of teleost is a paired organ located close to the operculum, at the dorsal side of the branchial cavity. Like in mammals, this tissue is responsible for the production of self-restricted and self-tolerant $\mathrm{T}$ cells facilitating and regulating interactions between lymphoid and non-lymphoid cells. The size of this tissue can vary over fish age, also depending on season changes and hormonal cycles (Press \& Evensen, 1999).

\section{Spleen}

The spleen is an oval organ located in the visceral cavity. It consists of a fibrous capsule with small trabeculae extended into the parenchyma, which can be divided in red and white pulp. Red pulp occupies the majority of the organ, embracing a reticular cell network supporting blood-filled sinusoids, which hold several cell populations such as macrophages and lymphocytes. The white pulp is usually thinly developed, but may be divided in two compartments: melanomacrophage accumulations and ellipsoids.

Spleen is considered as a secondary immune organ, playing an important role in responses against pathogen invasion. It acts as a selective filter of the vascular system (Press \& Evensen, 1999). The spleen also performs hemocateresis (red blood cells recycling) in several teleosts and promotes the maturation of the lymphocytes in both humoral and cellular defences (Press \& Evensen, 1999).

\subsection{Innate immune system}

The innate system is the first to respond against pathogens and is key in maintaining the homeostasis in animals (Magnadóttir, 2006; Riera et al., 2016). This system consists of a systemic and mucosal, cellular and humoral response that arrests the pathogen invasion, eliminating a wide range of microorganisms and debris, and activating the acquired immune system (Newton \& Dixit, 2012). In a first exposure to a new pathogen, a local inflammation is induced by the innate system (Newton \& Dixit, 2012), with the increase of vascular permeability allowing the arrival of cellular components to defeat the potential invasion. The cellular involvement in the inflammatory response in teleostean fish seems to be biphasic, starting with 
an influx of neutrophils followed by later arrival of monocytes/macrophages (Reite \& Evensen, 2006). The innate immune system is constituted of physicochemical barriers and humoral and cellular effectors. Physicochemical barriers are external protective structures (such as hardened scales), mucus secretions containing antimicrobial proteins (AMPs) (Ellis, 2001; Rakers et al., 2013), or low pH providing a hostile environment for pathogens to grow, which in case of malfunction can cause over-proliferation of microorganisms (Theisen et al., 2012). Humoral effectors are soluble proteins, contained in mucus secretions and plasma, with different activities, like lysozyme, antimicrobial peptides (trypsin-like or cathepsine), acute phase proteins, complement, lectins, cytokines, and natural antibodies (Ellis, 2001). Cellular innate effectors are monocytes/macrophages, granulocytes (mast cells, neutrophils, eosinophils, basophils), and natural cytotoxic cells (NCC). They act mostly by gobbling pathogens, and degranulating toxic compounds to the extracellular space to defeat pathogens. Their activation is through their pathogen recognition receptors (PRR), which recognise typical pathogen molecules (PAMPs, pathogen-associated molecular patterns) or damaged tissue molecules (DAMPs, damage-associated molecular patters), both orchestrated to keep the homeostasis in the animal (Muiswinkel \& Vervoorn-Van der Wal, 2006; Secombes \& Wang, 2012). Examples of those receptors are the C-type lectins (CLRs) or Toll-like receptors (TLRs), among others (Secombes \& Wang, 2012).

Macrophages are phagocytes with a key role in the defence and maintenance of homeostasis, and potentially can reside in all the tissues and organs in the body (Muiswinkel\&Vervoorn-Van der Wal, 2006). Monocytes are circulating macrophages, which differentiate into macrophages when they reach the target tissue. Via their PAMPS and DAMPS receptors, macrophages adopt the role of phagocytes, engulfing pathogens or injured cells, contributing to the local clearance and homeostasis in the fish (Secombes \& Fletcher, 1992). Moreover, macrophages have been described as antigen-presenting cells (APC), which activate T helper $\left(\mathrm{T}_{\mathrm{h}}\right)$ cells (see section 4. 3), taking part in the activation of the acquired immune response. Depending on the effector molecule that activates the macrophages, this will adopt pro-inflammatory (M1) or anti-inflammatory (M2) functions. M1 are macrophages with pro-inflammatory and defence functions, they secrete proinflammatory molecules and have high phagocytic and microbiocidal activities due to the production of antimicrobial enzymes/peptides and nitrogen and oxygen free radicals. M2 macrophages have anti-inflammatory and regulatory functions. They secrete anti-inflammatory molecules and phagocyte cell debris to keep the local homeostasis (Hodgkinson et al., 2015).

Granulocytes in teleost are very different in characteristics and abundance depending on the species of study. Generally, granulopoiesis in fish has been described in head kidney/pronephros (Meseguer et al., 1990, 1994; Temmink 
\& Bayne, 1987). The classification of mammalian granulocytes are based in tinctorial properties (Hine, 1992), e.g. affinities for acid or basic dyes. Briefly, in mammals, neutrophils are the most abundant, stained with fine mauve granules and are involved in the inflammation process; eosinophils, are less abundant than neutrophils, and their staining is orange-pink, and finally basophils are the less abundant and their granules are large and purple. However, in fish granulocytes, these properties do not mirror the functional diversity (Hine, 1992; Reite \& Evensen, 2006). When compared to mammals, some teleost species may lack neutrophil or eosinophil cells, and also basophils are rarely described (Hine, 1992). Functionally, all granulocytes are described for fish: neutrophils, eosinophils, basophils and mast cells. Classification of granulocytes in sparids includes functionally two types: neutrophils and heterophils, however, morphologically (staining properties) they are described as eosinophilic cells (Hine, 1992).

In particular, in Sparus aurata, two main groups of eosinophilic granule cells (EGCs) were described: mast cells (MC) and acidophilic granulocytes (Gómez-González et al., 2014) (AGs). In histology, both cell types are eosinophilic, stained magenta-red with Giemsa. However, using specific antibodies they can be differentiated: antihistamine, will recognize the histamine granules of mast cells, and the anti-G7 is a specific surface epitope of AGs (Estensoro et al., 2014; Sepulcre et al., 2002). MC are analogous to mammalian mast cells in their cytochemical characteristics and their function (Dezfuli \& Giari, 2008; Reite \& Evensen, 2006). In fact, MC are actively involved in bacterial and parasite clearance at mucosal sites through degranulation of antimicrobial peptides and enzymes like lysozyme (Corrales et al., 2010; Murray et al., 2007; Reite, 1998), histamine (exclusively described in perciforms among teleosts) (Mulero et al., 2007), piscidin 3 and likely piscidins 1 and 2 (Mulero et al., 2007, 2008). These are involved in inflammatory responses (Crivellato \& Ribatti, 2009; Mulero et al., 2007) inducing vasodilation, neutrophil attraction and migration, and macrophage activation (Lauriano et al., 2012). MC accumulate in large numbers in tissues exposed to pathological challenges and have been observed to exhibit distinct morphological changes, including degranulation (Dezfuli et al., 2012; Lamas et al., 1991; Reite \& Evensen, 1994). AGs, play a role equivalent to mammalian neutrophils, being the granulocytes which first arrive to injured tissue, and promote a higher inflammation for major cell recruitment (Hine, 1992). They are attracted to the injury by chemotactic signals, from the pathogens (PAMPs) or damaged tissue (DAMPs) (Secombes \& Wang, 2012). Once they reach the target tissue, they release antimicrobial substances into the extracellular space (reactive oxygen and nitrogen species, ROS and NOS), besides, they are also able to phagocytose (Havixbeck \& Barreda, 2015). 
Finally, non-specific cytotoxic cells (NCC) in fish, are considered homologous to mammalian natural killer cells (NK). The first piscine NK cell equivalents were described in channel catfish as NCCs bearing a vimentin-like surface molecule (Jaso-Friedmann et al., 1993) and expressing a type III membrane protein termed NCC receptor protein 1 (NCCRP-1) (Jaso-Friedmann et al., 1997). Another described molecule that is involved in NK cell responses is the NK cell enhancing factor (NKEF) which has been sequenced in several fish species (Chen et al., 2009). These cells remove infected cells by two mechanisms: 1) quick exocytosis of granules, such as perforins, NK lysins and granzymes that create pores in the membrane of the target cells inducing apoptosis and death, and 2) the slow FasL/Fas granuleindependent mechanism that induces apoptosis of the infected cell (Fischer et al., 2013; Zhuet al., 2016). NCCs and cytotoxic T cells compose the cell-mediated cytotoxicity branch of the immune system, which is responsible to recognize and kill infected cells (from virus and some bacteria), tumours and/or foreign cells (Cuesta et al., 2002). Specifically, S. aurata's NCC have been used to study the ability of combating mammalian tumour cells, contributing to the understanding of vertebrate immune system phylogenetics (Cuesta et al., 2002; Mulero et al., 1994). NK cells belong to the lymphoid linage, and thus their receptors are based in the recognition of the MHC-I (Groscurth, 1989), which usually has reduced expression levels in tumor cells.

Rodlet cells are exclusively found in bony fish and they are located at epithelial, mesothelial and endothelial linings (Manera \& Dezfuli, 2004; Reite \& Evensen, 2006; Sfacteria et al., 2015). There is evidence that their number varies as a response to different stressors and tissue injuries caused by viruses, parasites, toxins, or neoplasia. These cells seem to play a role in innate immunity; however, their function is still unclear (Manera \& Dezfuli, 2004).

\subsection{Acquired immune system}

The acquired immune system appeared in jawed animals, involving several important evolutionary changes, such as the lymphocyte development; RAG genes (enzymes responsible for B and T cell receptor diversity); and the thymus (Secombes \& Wang, 2012). The acquired immune system is mediated by the action of two major groups of cells: B and T lymphocytes, both having antigen-specific receptors. B cells mediate humoral responses and T cells are involved in cell-mediated immune responses (Mashoof \& Criscitiello, 2016). During maturation of B and T cells, their respective receptor locus (B-cell receptor, BCR or immunoglobulin, Ig; and T-cell receptor, TCR), is subjected to random genomic rearrangements of $\mathrm{V}, \mathrm{D}$, and $\mathrm{J}$ gene segments, leading to the expression of a unique antigen receptor by each lymphocyte (Magadanet al., 2015; Schatzet al., 1992). This mechanism is driven by 
the recombination-activating genes, RAG1 and RAG2 (Oettinger et al., 1990; Schatz et al., 1992; Wang et al., 2014). This recombination is responsible for the grand diversity of antigen recognition capacity in each individual (Tonegawa, 1983).

\section{T cells}

There are two types of T cells: $\mathrm{T}$ helper lymphocytes $\left(\mathrm{T}_{\mathrm{h}}\right)$, which mediate the activation of $B$ cells and cytotoxic $T$ lymphocytes $\left(T_{c}\right)$, which mediate the specific cytotoxic immune response (summarised in Figure 11). All $\mathrm{T}$ cells express the $\mathrm{T}$ cell receptor (TCR) and a co-receptor, CD4 for $\mathrm{T}_{\mathrm{h}}$ cells, or CD8 for $\mathrm{T}_{\mathrm{c}}$ cells. These co-receptors interact with major histocompatibility complex (MHC) molecules to activate T cells. $T_{h}$ cell activation happens via antigen presentation by APCs, which are cells able to phagocytise, process and display antigens by means of the MHCII. MHC-II interacts with CD4 $\mathrm{T}_{\mathrm{h}}$ cells activating a specific response depending on the nature of the antigen (Álvarez-Pellitero, 2011). $T_{c}$ cells are activated by the interaction of CD8 with MHC-I, which is present in every nucleated cell of the organism. MHC-I displays non-self antigens (e. g. virus, intracellular bacteria, tumour cells) activating a cytotoxic response against an infected or damaged cell (Secombes \& Wang, 2012).

\section{B cells}

The main task of B cells is the production of antibodies. The activation of B cells can be achieved by interaction with antigen-specific $\mathrm{T}_{h}$ cells; or by interaction with PRRs, which is independent from T cell activation (Cerutti et al., 2012; den Haan et al., 2014). Each B cell possesses a specific rearranged Ig on their surface (membrane Ig, BCR). When B cells get activated, they proliferate and start differentiating into plasma cells, which express the same Ig as a soluble protein. Secreted Igs constitute the main humoral factor in specific immunity (antibodies). Antibodies circulate in the bloodstream and permeate tissues and other body fluids where they bind specifically to the foreign antigen that stimulated their production. Antibodies specifically bind to the pathogen or toxin, directly impairing its fixation to the target tissue and spreading, and indirectly marking them to be processed by other effectors of the immune system (e. g. classic pathway of the complement or macrophages) (Iwama \& Nakanishi, 1996; Schroeder \& Cavacini, 2010; Secombes \& Wang, 2012). 


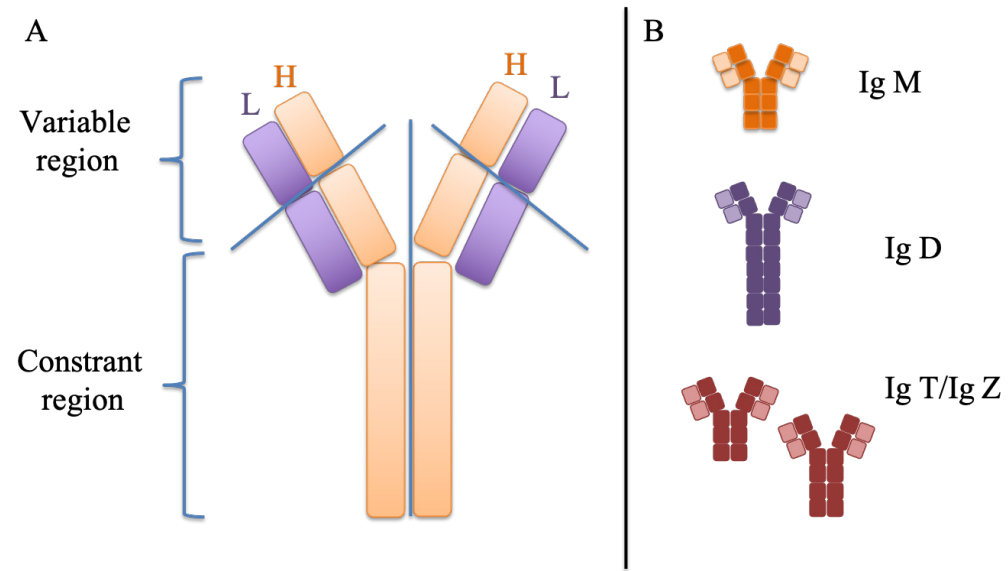

Figure 12. Monomer of Immunoglobulin scheme. A) Composed by two heavy (orange), and light chains (purple). In each chain, there is a variable region that interacts with the antigen, and the constant region, which determine the Ig isotype. B) Three Ig isotypes in fish: Ig M, Ig D and Ig T/Ig Z.

\section{Fish Immunoglobulins}

The basic structure of Ig consists of two identical heavy $(\mathrm{H})$ chains and two identical light (L) chains (Figure 12A). Both heavy and light chains contain one N-terminal variable domain (VH or $\mathrm{VL}$ ), in which a specific antigen binds, and one or more $\mathrm{C}$-terminal constant domains that form the constant region (CH or $\mathrm{CL}$ ). Concerning the constant region, three different isotypes for teleost have been described (Figure 12B): IgM, IgD and IgT/Z. IgM is the most abundant Ig in fish plasma, and it can be found as a monomer, but is more frequent as a tetramer (Secombes \& Wang, 2012). IgT is less abundant in serum, where is found as a monomer. IgT has been attributed a major role in mucosal tissues (Zhang et al., 2010), and is considered a functional homolog to mammalian IgA (Secombes \& Wang, 2012). In mucus, IgT is found as a tetramer (Secombes \& Wang, 2012).

\section{Immunological memory}

Fish immunological memory differs in several aspects with mammalian responses (du Pasquier, 2005; Farber et al., 2016; Mehr et al., 2004). On the one hand, tissues in which lymphoid cells are produced and mature are head kidney, spleen and peripheral tissues in fish, whereas bone marrow and germinal centres play this role in mammals (see section 4). Also, Ig modifications after a first contact with a specific antigen are different between fish and mammals. In mammals the Ig sequence changes in the subsequent encounters with the antigen, increasing its affinity, by hypermutation in germinal centres (Mehr et al., 2004; du Pasquier, 2005) resulting in Ig isotypes switch (Ma et al., 2013). In fish, mechanisms driving affinity maturation are not well described. The increase in antibody specificity is around 6-fold after the first encounter, and no further increase in affinity has been observed in subsequent encounters. In addition, Ig class switching is not present in fish. Figure 13, summarises the sequential scenarios in the fish antibody response. 


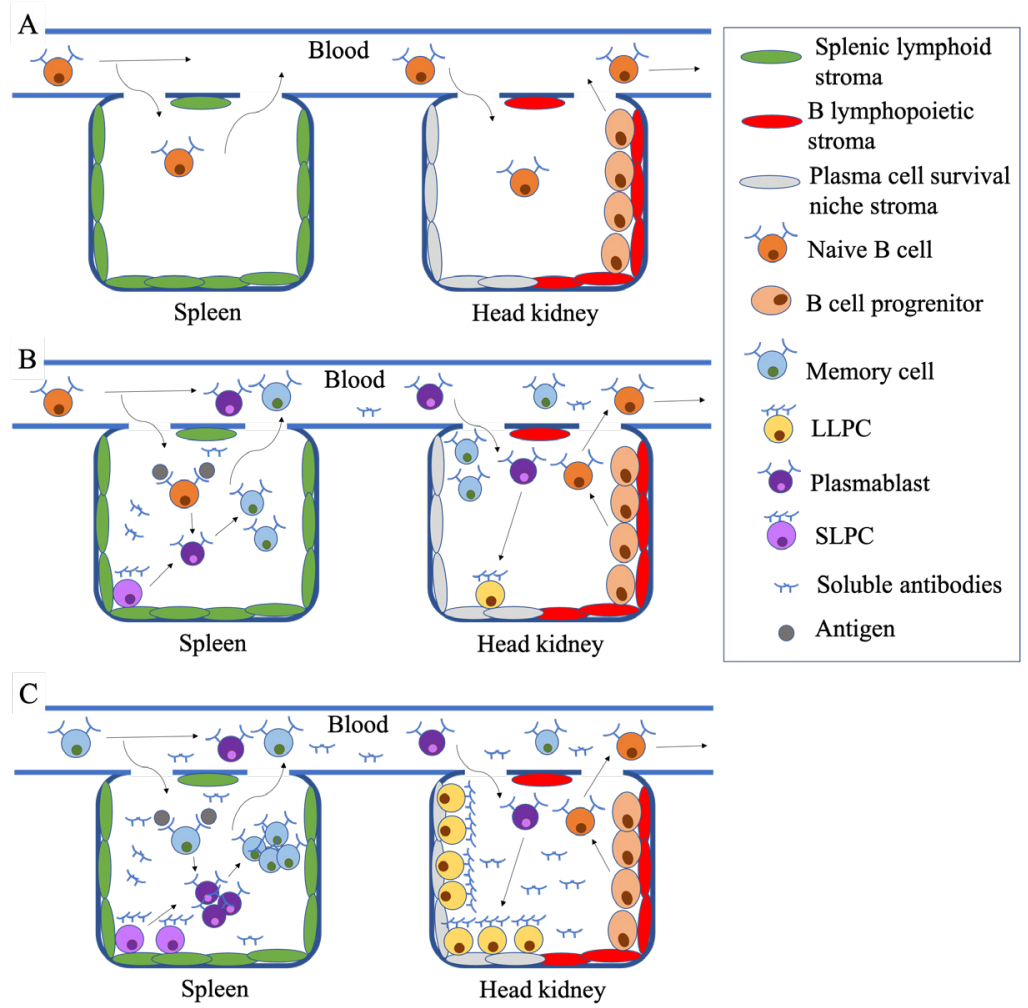

Figure 13. B cell response in fish (Spacial/temporal). A) Preimmune stage. Within the lymphopoietic stromal niches of the anterior kidney (red), naïve B cells are produced and released to the peripheral blood, eventually circulating through the peripheral tissues and spleen. B) Primary response. An antigen is trapped and presented within the context of splenic stroma (green) and auxiliary cells, the naive B cell undergoes differentiation and plasmablast proliferation. These plasmablasts give rise to short-lived plasma cells (SLPCs) and Memory cells. Some plasmablasts exit the spleen and migrate to plasma cell survival niches in the anterior kidney (grey) where they become long-lived plasma cells LLPCs. C) Secondary response to antigen results in an expanded antibody response due to the previous accumulation of memory cells (memory response). New plasmablasts may continue to seed survival niches with more LLPCs which may displace older LLPCs (no showed). Adaptation of Ma et al., 2013.

B cells precursors, established in the head kidney stroma, produce naïve B cells (no antigen-reactive). These naïve $B$ cells move to spleen and peripheral tissues, were they encounter a specific antigen and differentiate into plasmablasts (replicative cells). These plasmablasts would differentiate into different antibody producing cells: short-lived plasma cells (SLPC) and memory B cells (MBC). In addition, a few of these plasmablasts would migrate to head kidney were they will differentiate into long-lived plasma cells (LLPC) (Ma et al., 2013). Timings in primary response, i. e. duration of lag, exponential and decay phases, greatly depend on the type of antigen, antigen dose, route of administration, age and species (Muiswinkel \& Vervoorn-Van der Wal, 2006). However, in the case of ectotherms, water temperature also plays an important role (Muiswinkel \& Vervoorn-Van der Wal, 2006; Rijkers et al., 1980). 
Despite the differences, fish and mammalian responses still have several aspects in common. Long lasting memory cells establish their niche in hematopoietic tissues, which are the bone marrow in mammals and head kidney in fish (Ma et al., 2013), but also memory B cells can be established in peripheral organs like blood, spleen or mucosal tissues. Memory is the basis of vaccination (Buchmann et al., 2001) (Figure 14), thus its study can unveil an important path to defeat the pathogenic threats.

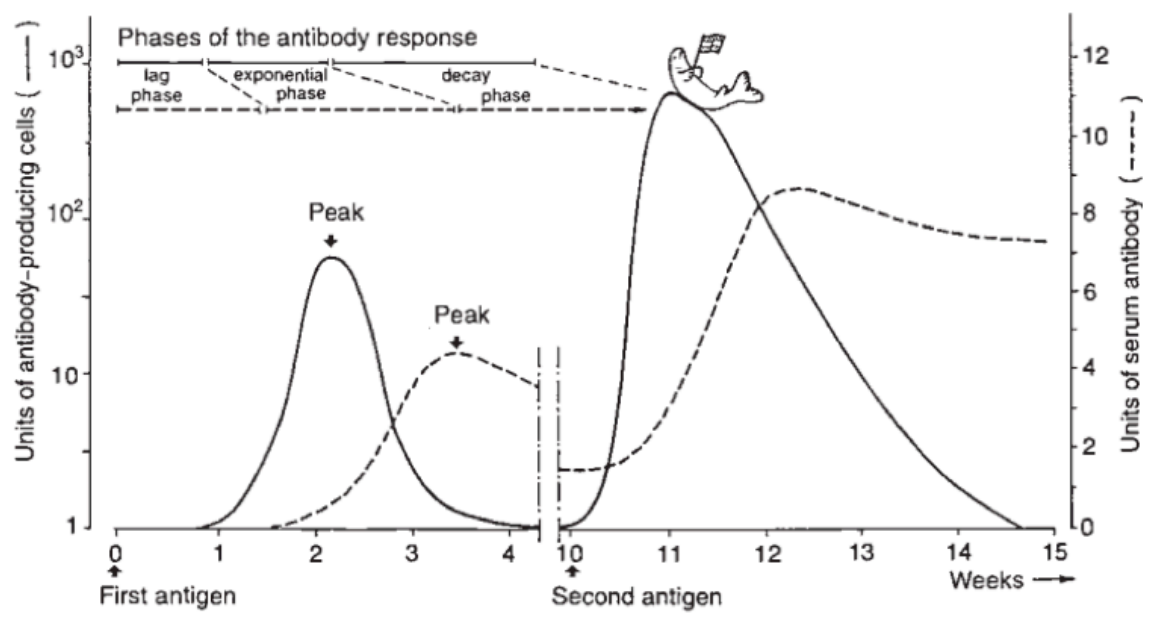

Figure 14. Primary and secondary immune responses in teleost. Adaptation from Muiswinkel et al., 2006.

A great focus of this thesis is on the secondary immune response of gilthead sea bream against the myxozoan parasite $E$. leei. The protective potential of these responses and how they could be exploited towards generating prophylactic tools against enteromyxosis in aquaculture are studied in depth in chapter 4.

Immunity is the ability to overcome a threatening organism through immune effectors. This event may happen actively as a consequence of direct contact with the pathogen by chance, artificially (vaccination), or passively by transference of specific Igs of resistant individuals. Passive immunization can happen vertically, from maternal transference, or experimentally by direct serum or antibody injection (Rajan et al., 2017). Advantages and disadvantages are present in both types of immunity. On one side, active immunity is characterised by having a lag phase (delayed response), since $B$ cells need $\mathrm{T}_{\mathrm{h}}$ cells to be activated, however, memory against the pathogen would be developed, and in secondary encounters, acquired immune responses will be quicker and higher (Secombes \& Wang, 2012). On the other side, passive immunization is quick, since humoral factors are already available to interact with pathogens, but memory against the pathogen will not be developed (Rajan et al., 2017). In Chapter 3, passive immunization will be studied in depth in the host-parasite model: E. leei - S. aurata. 


\section{Bibliography}


Abd-Elfattah A., Fontes I., Kumar G., Soliman H., Hartikainen H., Okamura B., El-Matbouli M. (2014a) Vertical transmission of Tetracapsuloides bryosalmonae (Myxozoa), the causative agent of salmonid proliferative kidney disease. Parasitology. 141:482-490.

Abd-Elfattah A., Kumar G., Soliman H., El-Matbouli M. (2014b) Persistence of Tetracapsuloides Bryosalmonae (Myxozoa) in chronically infected brown trout Salmo trutta. Dis Aquat Org. 111:41-49.

Abela M., Brinch-Iversen J., Tanti J., le Breton A. (1996) Occurrence of a new histozoic microsporidian (Protozoa, Microspora) in cultured gilt head sea bream Sparus aurata L. Bull Eur Assoc Fish Pathol. 16:196-199.

Agius C., Roberts R. J. (2003) Melano-macrophage centres and their role in fish pathology. J Fish Dis. 26:499-509.

Ahmed N. H., Caffara M., Sitjà-Bobadilla A., Fioravanti M. L., Mazzone A., Aboulezz A. S., Metwally A. M., Omar A. M., Palenzuela O. (2019) Detection of the intranuclear microsporidian Enterospora nucleophila in gilthead sea bream by in situ hybridization. J Fish Dis. 42:809-815.

Alberts B., Johnson A., Lewis J. (2002) The Adaptive Immune System, in: Alberts B., Johnson A., Lewis J., Raff M., Roberts K., Walter P. (Eds.) Molecular Biology of the Cell. Garland Science, New York, USA. pp. 1297-1344.

Álvarez-Pellitero P. (2011) Mucosal intestinal immunity and response to parasite infections in ectothermic vertebrates, in: Álvarez-Pellitero P. (Ed.) Nova Novinka, UK.

Álvarez-Pellitero P., Palenzuela O., Sitjà-Bobadilla A. (2008) Histopathology and cellular response in Enteromyxum leei (Myxozoa) infections of Diplodus puntazzo (Teleostei). Parasitol Int. 57:110-120.

Álvarez-Pellitero P., Sitjà-Bobadilla A. (2002) Cryptosporidium molnari n. sp (Apicomplexa: Cryptosporidiidae) infecting two marine fish species, Sparus aurata L. and Dicentrarchus labrax L. Int J Parasitol. 32:1007-1021.

Álvarez-Pellitero P., Sitjà-Bobadilla A., Franco-Sierra A., Palenzuela O. (1995) Protozoan parasites of gilthead sea bream, Sparus aurata L., from different culture systems in Spain. J Fish Dis. 18:105-115.

Antonio D. B., Hedrick R. P. (1995) Effect of water temperature on infections with the microsporidian Enterocytozoon salmonis in chinook salmon. Dis Aquat Org. 22:233-236.

Athanassopoulou F. (1998) A case report of Pleistophora sp. infection in cultured sea bream (Sparus aurata L.) in Greece. Bull Eur Assoc Fish Pathol. 18:19-21.

Atkinson S. D., Bartholomew J. L., Lotan T. (2018) Myxozoans: Ancient metazoan parasites find a home in phylum Cnidaria. Zoology. 129:66-68.

Bailey C., Holland J. W., Secombes C. J., Tafalla C. (2020) A portrait of the immune response to proliferative kidney disease (PKD) in rainbow trout. Parasite Immunol. 42:e12730.

Bartholomew J. L., Atkinson S. D., Hallett S. L., Lowenstine L. J., Garner M. M., Gardiner C. H., Rideout B. A., Keel M. K., Brown J. D. (2008) Myxozoan parasitism in waterfowl. Int J Parasitol. 38:1199-1207.

Bartholomew J. L., Whipple M. J., Stevens D. G., Fryer J. L. (1997) The life cycle of Ceratomyxa shasta, a myxosporean parasite of salmonids, requires a freshwater polychaete as an alternate host. J Parasitol. 83:859-868.

Baxa D., Groff J., Hedrick R. (1992) Experimental horizontal transmission of Enterocytozoon salmonis to chinook salmon, Oncorhynchus tshawytscha. J Protozool. 39:699-702.

Biassoni R. (2009) Human natural killer receptors, co-receptors, and their ligands. Curr Protoc Immunol.121:e47.

Bonilla F. A., Oettgen H. C. (2010) Adaptive immunity. J Allergy Clin Immunol. 125:33-40.

le Breton A., Marques A. (1995) Occurrence of an histozoic myxidium infection in two marine cultured species: Puntazzo puntazzo C. and Pagrus major. Bull Eur Assoc Fish Pathol. 15:210-212.

Brinchmann M. F. (2016) Immune relevant molecules identified in the skin mucus of fish using -omics technologies. Mol Biosyst. 12:2056-2063. 
Buchmann K., Lindenstrom T., Bresciani J. (2001) Defence mechanisms against parasites in fish and the prospect for vaccines. Acta Parasitol. 46:71-81.

Caffara M., Sirri R., Mandrioli L., Gustinelli A., Fioravanti M. (2014) Sindrome emaciativa da Enterospora nucleophila (Microsporidia) in orate (Sparus aurata) allevate in Italia. Proceedings of the XX Convegno Nazionale SIPI. Pisa, Italy. pp. 44.

Caffara M., Marcer F., Florio D., Quaglio F., Fioravanti M. L. (2003) Heart infection due to Henneguya sp (Myxozoa, Myxosporea) in gilthead sea bream (Sparus aurata) cultured in Italy. Bull Eur Assoc Fish Pathol. 23:108-112.

Cali A., Becnel J., Takvorian P. (2017) Microsporidia, in: Archibald J. M., Simpson A. G. B., Slamovits C. H. (Eds.) Handbook of the Protists, Second Edition. Springer International Publishing, Switzerland. pp. 1559-1618.

Cameron Brown, R. (2003) Genetic management and selective breeding in farmed populations of gilthead sea bream (Sparus aurata). Ph. D. thesis, University of Stirling, Stirling, UK.

Cano R. L. E., Lopera H. D. E. (2013) Introduction to T and B lymphocytes, in: Anaya J. M., Shoenfeld Y., RojasVillarraga A. (Eds.) Autoimmunity: From bench to bedside. El Rosario University Press, Bogota, Colombia. pp. 77-96.

Canning E. U., Curry A., Feist S. W., Longshaw M., Okamura B. (2000) A new class and order of myxozoans to accommodate parasites of bryozoans with ultrastructural observations on Tetracapsula bryosalmonae (PKX Organism). J Eukaryot Microbiol. 47:456-468.

Canning U. E., Okamura B. (2004) Biodiversity and evolution of the Myxozoa. Adv Parasitol. 56:43-131.

Capella-Gutiérrez S., Marcet-Houben M., Gabaldón T. (2012) Phylogenomics supports microsporidia as the earliest diverging clade of sequenced fungi. BMC Biol.10:47.

Cerutti A., Cols M., Puga I. (2012) Activation of B cells by non-canonical helper signals. EMBO Rep. 13:798-810.

Chang E. S., Neuhof M., Rubinstein N. D., Diamant A., Philippe H., Huchon D., Cartwright P. (2015) Genomic insights into the evolutionary origin of myxozoa within Cnidaria. Proc Natl Acad Sci USA. 112:14912-14917.

Chen J., Wu H., Niu H., Shi Y., Li M. (2009) Increased liver protein and mRNA expression of natural killer cellenhancing factor B (NKEF-B) in ayu (Plecoglossus altivelis) after Aeromonas hydrophila infection. Fish Shellfish Immunol. 26:567-571.

China M., Nakamura H., Hamakawa K., Tamaki E., Miwa S., Meng F., Yokoyama H. (2013) Occurrence of the myxosporean emaciation disease caused by Enteromyxum leei in cultured malabar grouper Epinephelus malabaricus. Fish Pathol. 48, 88-96.

China M., Nakamura H., Hamakawa K., Tamaki E., Yokoyama H., Masuoka S., Ogawa K. (2014) Efficacy of high water temperature treatment of myxosporean emaciation disease caused by Enteromyxum leei (Myxozoa). Fish Pathol. 49:137-140.

Corrales J., Mulero I., Mulero V., Noga E. J. (2010) Detection of antimicrobial peptides related to piscidin 4 in important aquacultured fish. Dev Comp Immunol. 34:331-343.

Costello M. J. (2006) Ecology of sea lice parasitic on farmed and wild fish. Trends Parasitol. 22:475-483.

Crivellato E., Ribatti D. (2009) The mast cell: An evolutionary perspective. Biol Rev Camb Philos. 85:347-360.

Cuadrado M., Marques A., Diamant A., Sitjà-Bobadilla A., Palenzuela O., Álvarez-Pellitero P., Padrós F., Crespo S. (2008) Ultrastructure of Enteromyxum leei (Diamant, Lom \& Dyková, 1994) (Myxozoa), an enteric parasite infecting gilthead sea bream (Sparus aurata) and sharpsnout sea bream (Diplodus puntazzo). J Eukaryot Microbiol. 55:178-184.

Cuesta A., Esteban M., Meseguer J. (2002) Natural cytotoxic cells of gilthead seabream: Maximum percentage of lysis. Fish Shellfish Immunol. 12:111-118.

Dannevig B. H., Lauve A., Press C. M., Landsverk T. (1994) Receptor-mediated endocytosis and phagocytosis by rainbow trout head kidney sinusoidal cells. Fish Shellfish Immunol. 4:3-18.

Deivasigamani B. (2007) Structure of immune organ in edible catfish, Mystus gulio. J Environ Biol. 28:757-764. 
Dempsey P. W., Vaidya S. A., Cheng G. (2003) The art of war: Innate and adaptive immune responses. Cell Mol Life Sci. 60:2604-2621.

den Haan J. M. M., Arens R., van Zelm M. C. (2014) The activation of the adaptive immune system: Cross-talk between antigen-presenting cells, T cells and B cells. Immunol Lett. 162:103-112.

Dezfuli B. S., Giari L. (2008) Mast cells in the gills and intestines of naturally infected fish: Evidence of migration and degranulation. J Fish Dis. 31:845-852.

Dezfuli B. S., Lui A., Giari L., Castaldelli G., Mulero V., Noga E. J. (2012) Infiltration and activation of acidophilic granulocytes in skin lesions of gilthead seabream, Sparus aurata, naturally infected with lymphocystis disease virus. Dev Comp Immunol. 36:174-182.

Diamant A. (1995) Myxidium leei (Myxosporea) infections in sharpsnout sea bream Diplodus puntazzo (Cetti) and common sea bream Pagrus pagrus (L.) (Sparidae). Program and book of abstracts Institute of Zoology, Fish Biology and Fish Diseases, 4th lnt. Symp Fish Parasitology. Munich, Germany. pp. 8.

Diamant A., Lom J., Dyková I. (1994) Myxidium leei n. sp., a pathogenic myxosporean of cultured sea bream Sparus aurata. Dis Aquat Org. 20:137-141.

Diamant A., Ram S., Paperna I. (2006) Experimental transmission of Enteromyxum leei to freshwater fish. Dis Aquat Org. 72:171-178.

Diamant A., Ucko M., Paperna I., Colorni A., Lipshitz A. (2005) Kudoa iwatai (Myxosporea: Multivalvulida) in wild and cultured fish in the Red Sea: Redescription and molecular phylogeny. J Parasitol. 91:1175-1189.

Diamant A., Wajsbrot N. (1997) Experimental transmission of Myxidium leei in gilthead sea bream Sparus aurata. Bull Eur Assoc Fish Pathol. 17:99-103.

du Pasquier L. (2005) Meeting the demand for innate and adaptive immunities during evolution. Scand J Immunol. 62:39-48.

Eiras J. C. (2005) An overview on the myxosporean parasites inamphibians and reptiles. Acta Parasitol. 50:267-275.

Ellis A. E. (2001) Innate host defense mechanisms of fish against viruses and bacteria. Dev Comp Immunol. 25:827839.

El-Matbouli M., Fischer-Scherl T., Hoffmann R. W. (1992) Transmission of Hoferellus carassii Achmerov, 1960 to goldfish Carassius auratus via an aquatic oligochaete. Bull Eur Assoc Fish Pathol. 12:54-56.

Estensoro I. (2013) Enteromyxum leei (Myxozoa: Myxosporea) infection in gilthead sea bream (Sparus aurata): Immune-related studies. Ph. D. thesis, Universidad de Valencia, Valencia, Spain.

Estensoro I., Mulero I., Redondo M. J., Álvarez-Pellitero P., Mulero V., Sitjà-Bobadilla A. (2014) Modulation of leukocytic populations of gilthead sea bream (Sparus aurata) by the intestinal parasite Enteromyxum leei (Myxozoa: Myxosporea). Parasitology. 141:425-440.

Estensoro I., Redondo M. J., Álvarez-Pellitero P., Sitjà-Bobadilla A. (2010) Novel horizontal transmission route for Enteromyxum leei (myxozoa) by anal intubation of gilthead sea bream Sparus aurata. Dis Aquat Org. 92:51-58.

Eszterbauer E., Atkinson S., Diamant A., Morris D., El-Matbouli M., Hartikainen H. (2015) Myxozoan life cycles: practical approaches and insights, in: Okamura B., Gruhl A., Bartholomew J. L. (Eds.) Myxozoan Evolution, Ecology and Development. Springer International Publishing, Switzerland. pp. 201-213.

Faisal M., Imam E. A. (1990) Microcotyle chrysophrii (Monogenea, Polyopisthocotylea), a pathogen for cultured and wild gilthead seabream, Sparus aurata. Proceedings of the Third International Colloquium on Pathology in Marine Aquaculture, Virginia, USA. pp. 283-290.

Farber D. L., Netea M. G., Radbruch A., Rajewsky K., Zinkernagel R. M. (2016) Immunological memory: Lessons from the past and a look to the future. Nat Rev Immunol. 16:124-128.

Feist S. W., Morris D., Alama-Bermejo G., Holzer A. S. (2015) Cellular processes in Myxozoans, in: Okamura B., Gruhl A., Bartholomew J. L. (Eds.) Myxozoan Evolution, Ecology and Development. Springer International Publishing, Switzerland. pp.139-151. 
Feist S., Longshaw M. (2006) Phylum Myxozoa, in: Woo P. T. K. (Ed.) Fish Diseases and Disorders. CAB International, Oxfordshire, UK. Vol.1.pp. 230.

Fiala I., Bartošová-Sojková P., Whipps C. (2015) Classification and phylogenetics of Myxozoa, in: Okamura B., Gruhl A., Bartholomew J. L. (Eds.) Myxozoan Evolution, Ecology and Development. Springer International Publishing, Switzerland. pp. 85-110.

Figueras A., Novoa B., Santarem M., Martínez E., Álvarez J. M., Toranzo A., Dyková I. (1992) Tetramicra brevifilum, a potential threat to farmed turbot Scophthalmus maximus. Dis Aquat Org. 14:127-35.

Fioravanti M. L., Caffara M., Florio D., Gustinelli A., Marcer F. (2006) A parasitological survey of european sea bass (Dicentrarchus labrax) and gilthead sea bream (Sparus aurata) cultured in Italy. Vet Res Commun. 31:235-236.

Fischer U., Koppang E. O., Nakanishi T. (2013) Teleost T and NK cell immunity. Fish Shellfish Immunol. 35:197-206.

Flajnik M. F. (2018) A cold-blooded view of adaptive immunity. Nat Rev Immunol. 18:438-453.

Fleurance R., Sauvegrain C., Marques A., le Breton A., Guereaud C., Cherel Y., Wyers M. (2008) Histopathological changes caused by Enteromyxum leei infection in farmed sea bream Sparus aurata. Dis Aquat Org. 79:219-228.

Fontes I., Hartikainen H., Holland J., Secombes C., Okamura B. (2017) Tetracapsuloides bryosalmonae abundance in river water. Dis Aquat Org. 124: 145-157.

Freeman M. A., Kasper J. M., Kristmundsson Á. (2013) Nucleospora cyclopteri n. sp., an intranuclear microsporidian infecting wild lumpfish, Cyclopterus lumpus L., in Icelandic waters. Parasit Vectors. 6:49.

Friedrich C., Ingolic E., Freitag B., Kastberger G., Hohmann V., Skofitsch G., Neumeister U., Kepka O. (2000) A myxozoan-like parasite causing xenomas in the brain of the mole, Talpa europaea L., 1758 (Vertebrata, Mammalia). Parasitology. 121:483-492.

Galindo-Villegas J., Hosokawa H. (2004) Immunostimulants: Towards temporary prevention of diseases in marine fish. Memorias del VII Simposium Internacional de Nutrición Acuícola. Hermosillo, México. pp. $273-319$.

Gatto D., Brink R. (2010) The germinal center reaction. J Allergy Clin Immunol. 126:898-907.

Golomazou E., Athanassopoulou F., Karagouni E., Tsagozis P., Tsantilas H., Vagianou S. (2006) Experimental transmission of Enteromyxum leei Diamant, Lom and Dyková, 1994 in sharpsnout sea bream, Diplodus puntazzo C. and the effect on some innate immune parameters. Aquaculture. 260:44-53.

Gómez-González N. E., García-García E., Montero J., García-Alcazar A., Meseguer J., García-Ayala A., Mulero V. (2014) Isolation of mast cells from the peritoneal exudate of the teleost fish gilthead sea bream (Sparus aurata L.). Fish Shellfish Immunol. 40:225-232.

Good-Jacobson K. L., Shlomchik M. J. (2010) Plasticity and heterogeneity in the generation of memory B cells and long-lived plasma cells: The influence of germinal center interactions and dynamics. J Immunol. 185:3117-3125.

Grabner D. S., El-Matbouli M. (2010) Experimental transmission of malacosporean parasites from bryozoans to common carp (Cyprinus carpio) and minnow (Phoxinus phoxinus). Parasitology. 137:629-639.

Grabner D. S., El-Matbouli M. (2008) Transmission of Tetracapsuloides bryosalmonae (Myxozoa: Malacosporea) to Fredericella sultana (Bryozoa: Phylactolaemata) by various fish species. Dis Aquat Org. 79:133-139.

Groscurth P. (1989) Cytotoxic effector cells of the immune system. Anat Embryol. 180:109-119.

Han B., Weiss L. M. (2017) Microsporidia: Obligate intracellular pathogens within the fungal kingdom. Microbiol Spectr. 5 .

Havixbeck J. J., Barreda D. R. (2015) Neutrophil development, migration, and function in teleost fish. Biology (Basel). 4:715-734.

Hedrick R. P., Baxa D. V., Kinkelin P. D., Okamura B. (2004) Malacosporean-like spores in urine of rainbow trout react with antibody and DNA probes to Tetracapsuloides bryosalmonae. Parasitol Res. 92:81-88. 
Hine P. M. (1992) The granulocytes of fish. Fish Shellfish Immunol. 2:79-98.

Hodgkinson J. W., Grayfer L., Belosevic M. (2015) Biology of bony fish macrophages. Biology. 4:881-906.

Holzer A. S., Montero F. E., Repullés A., Nolan M. J., Sitjà-Bobadilla A., Álvarez-Pellitero P., Zarza C., Raga J. A. (2008) Cardicola aurata Sp n. (Digenea: Sanguinicolidae) from mediterranean Sparus aurata L. (Teleostei: Sparidae) and its unexpected phylogenetic relationship with Paradeontacylix McIntosh, 1934. Parasitol Int. 57:472-482.

Husband A. J. (2001) Overview of the Mammalian Immune System, in: Woodward B., Draper H. H. (Eds.) Advances in Nutritional Research. Springer, Boston, MA. Vol. 10.

Huttenhuis H. B. T., Huising M. O., van der Meulen T., van Oosterhoud C. N., Álvarez-Sánchez N., Taverne-Thiele A. J., Stroband H. W. J., Rombout J. H. W. M. (2005) RAG expression identifies B and T cell lymphopoietic tissues during the development of common carp (Cyprinus carpio). Dev Comp Immunol. 29:1033-1047.

Hyatt M. W., Waltzek T. B., Kieran E. A., Frasca S., Lovy J. (2018) Diagnosis and treatment of multi-species fish mortality attributed to Enteromyxum leei while in quarantine at a US aquarium. Dis Aquat Org. 132:37-48.

Iwama G., Nakanishi, T. (1996) The Fish Immune System Organism, Pathogen, and Environment, in: Hoar W., Randall D., (Eds.) Academic Press. San Diego, USA.

Iwanowicz D. (2011) Overview on the effects of parasites on fish health. Proceedings of the Third Bilateral Conference between Russia and the United States. 3:176-181.

Jaso-Friedmann L., Leary H., Evans D. L. (1993) Nonspecific cytotoxic cells in fish: Antigenic cross-reactivity of a function associated molecule with the intermediate filament vimentin. Cell Immunol. 148:208-217.

Jaso-Friedmann L., Leary J. H., Evans D. L. (1997) NCCRP-1: A novel receptor protein sequenced from teleost nonspecific cytotoxic cells. Mol Immunol. 34:955-965.

Jung C., Hugot J. P., Barreau F. (2010) Peyer's patches: The immune sensors of the intestine. Int J Inflam. 823710.

Karvonen A., Rintamäki P., Jokela J., Valtonen E. T. (2010) Increasing water temperature and disease risks in aquatic systems: Climate change increases the risk of some, but not all, diseases. Int J Parasitol. 40:1483-1488.

Kennedy D., Kurath G., Brito I., Purcell M., Read A., Winton J., Wargo A. (2015) Potential drivers of virulence evolution in aquaculture. Evol Appl. 11:344-354.

Kent M. L., Shaw R. W., Sanders J. L. (2014) Microsporidia in Fish, in: Weiss L. M., Becnel J. J. (Eds.) Microsporidia: Pathogens of Opportunity. Wiley-Backwell, Ames, Iowa, USA. pp. 493-520.

Kent M. L. (1986) Development of the PKX Myxosporean in rainbow trout Salmo gairdneri. Dis Aquat Org. 1:169182.

Kent M. L., Andree K. B., Bartholomew J. L., El-Matbouli M., Desser S. S., Devlin R. H., Feist S. W., Hedrick R. P., Hoffmann R. W., Khattra J., Hallett S. L., Lester R. J., Longshaw M., Palenzeula O., Siddall M. E., Xiao C. (2001) Recent advances in our knowledge of the Myxozoa. J Eukaryot Microbiol. 48:395-413.

Kristmundsson A., Freeman M. A. (2014) Negative effects of Kudoa islandica n. sp. (Myxosporea: Kudoidae) on aquaculture and wild fisheries in Iceland. Int J Parasitol Parasites Wildl. 3:135-146.

Kum C., Sekkin S. (2011) The immune system drugs in fish: Immune function, immunoassay, drugs, in: Aral F., Dogu Z. (Eds.) Recent Advances in Fish Farms. IntechOpen. pp. 169-210.

Kumar G., Abdelfattah A., Saleh M., El-Matbouli M. (2013) Fate of Tetracapsuloides bryosalmonae (Myxozoa) after infection of brown trout Salmo trutta and rainbow trout Oncorhynchus mykiss. Dis Aquat Org. 107:9-18.

Lamas J., Bruno D. W., Santos Y., Anadón R., Ellis A. E. (1991) Eosinophilic granular cell response to intraperitoneal injection with Vibrio anguillarum and its extracellular products in rainbow trout, Oncorhynchus mykiss. Fish Shellfish Immunol. 1:187-194.

Lauriano E. R., Calò M., Silvestri G., Zaccone D., Pergolizzi S., Lo Cascio P. (2012) Mast cells in the intestine and gills of the sea bream, Sparus aurata, exposed to a polychlorinated biphenyl, PCB 126. Acta Histochem. 114:166-171. 
Lazado C. C., Caipang C. M. A. (2014) Mucosal immunity and probiotics in fish. Fish Shellfish Immunol. 39:78-89.

Løken O. M., Bjørgen H., Hordvik I., Koppang E. O. (2019) A teleost structural analogue to the avian bursa of fabricius. J Anat. 236:798-808.

Lom J., Dyková I. (2006) Myxozoan genera: Definition and notes on taxonomy, life-cycle terminology and pathogenic species. Folia Parasitol. 53:1-36.

Ma C., Ye J., Kaattari S. L. (2013) Differential compartmentalization of memory B cells versus plasma cells in salmonid fish. Eur J Immunol. 43:360-370.

Magadan S., Sunyer O. J., Boudinot P. (2015) Unique features of fish immune repertoires: Particularities of adaptive immunity within the largest group of vertebrates, in: Hsu E., Du Pasquier L. (Eds.) Pathogen-host interactions: Antigenic Variation v. Somatic Adaptations. Results and Problems in Cell Differentiation. Springer, Cham. Vol. 57.

Magnadóttir B. (2006) Innate immunity of fish (overview). Fish Shellfish Immunol. 20:137-151.

Manera M., Dezfuli B. S. (2004) Rodlet cells in teleosts: A new insight into their nature and functions. J Fish Biol. 65:597-619.

Marino F., Macri D., Paruta S., Busalacchi B, Genovese L., De Vigo C. (2004) Black spot seabream (Pagellus bogaraveo), a new susceptible host for Myxidium leei. Extended Abstracts and Short Communications Booklet. Barcelona, Spain. Vol. 34. pp. 524-525.

Mashoof S., Criscitiello F. M. (2016) Fish immunoglobulins. Biology. 5:45.

Mason K. L., Huffnagle G. B., Noverr M. C., Kao J. Y. (2008) Overview of gut immunology. Adv Exp Med Biol. 635:1-14.

Massard J., Geimer G. (2008) Global diversity of bryozoans (Bryozoa or Ectoprocta) in freshwater. Hydrobiologia. 595:93-99.

Mathieu-Daude F., Faye N., Coste F., Manier J. F., Marques A., Bouix G. (1992) Occurence of a microsporidiosis in marine cultured gilthead sea bream from the languedoc coast: A problem of specificity in the genus Glugea (Protozoa, Microspora). Bull Eur Assoc Fish Pathol. 12:67-70.

Matthews R. A., Matthews B. F. (1980) Cell and tissue reactions of turbot Scophthalmus maximus (L.) to Tetramicra brevifilum gen. n., sp. n. (Microspora). J Fish Dis. 3:495-515.

Mehr R., Edelman H., Sehgal D., Mage R. (2004) Analysis of mutational lineage trees from sites of primary and secondary Ig gene diversification in rabbits and chickens. J Immunol. 172:4790-4796.

Meseguer J., Esteban M. A., García-Ayala A., López-Ruíz A., Agulleiro B. (1990) Granulopoiesis in the head-kidney of the sea bass (Dicentrarchus labrax L.): An ultrastructural study. Arch Histol Cytol. 53:287-296.

Meseguer J., López-Ruíz A., Esteban M. A. (1994) Cytochemical characterization of leukocytes from the seawater teleost, gilthead seabream (Sparus aurata L). Histochemistry. 102:37-44.

Meyer F. P. (1991) Aquaculture disease and health management. J Anim Sci. 69:4201-4208.

Mladineo I. (2003) Life cycle of Ceratothoa oestroides, a cymothoid isopod parasite from sea bass Dicentrarchus labrax and sea bream Sparus aurata. Dis Aquat Org. 57:97-101.

Monir M. S., Bagum N., Rahman S., Ashaf-Ud-Doulah M., Bhadra A., Borty S. C. (2015) Parasitic diseases and estimation of loss due to infestation of parasites in Indian major carp culture ponds in Bangladesh. Int J Fish Aquat Stud. 2:118-122.

Moretti A., Pedini Fernández-Criado M., Vetillart R. (2005) Manual on hatchery production of sea bass and gilthead sea bream, in: FAO. Rome, Italy. Vol 2. pp.152.

van Muiswinkel W. B., Vervoorn-Van der Wal B. (2006) The immune system of fish, in: Woo P. T. K. (Ed.) Fish Diseases and Disorders. CAB International, Canada. pp. 678-701.

Mulero I., Noga E. J., Meseguer J., García-Ayala A., Mulero V. (2008) The antimicrobial peptides piscidins are stored in the granules of professional phagocytic granulocytes of fish and are delivered to the bacteria-containing phagosome upon phagocytosis. Dev Comp Immunol. 32:1531-1538. 
Mulero I., Sepulcre M. P., Meseguer J., García-Ayala A., Mulero V. (2007) Histamine is stored in mast cells of most evolutionarily advanced fish and regulates the fish inflammatory response. Proc Nat. Acad Sci USA. 104:1943419439.

Mulero V., Esteban M. A., Muñoz J., Meseguer J. (1994) Non-specific cytotoxic response against tumor target cells mediated by leucocytes from seawater teleosts, Sparus aurata and Dicentrarchus labrax: An ultrastructural study. Arch Histol Cytol. 57:351-358.

Murray H. M., Leggiadro C. T., Douglas S. E. (2007) Immunocytochemical localization of pleurocidin to the cytoplasmic granules of eosinophilic granular cells from the winter flounder gill. J Fish Biol. 70:336-345.

Newton K., Dixit V. M. (2012) Signaling in innate immunity and inflammation. CSH Perspect Biol. 4:a006049.

Odai M., Ikegami T., Ortega A., García-Alcázar A., Arnal I., Santaella E., Guevara J., Sandino S., Peñalver L. (1978) Experiencias sobre cultivos de larvas de Palaemon serratus, Penaeus kerathurus y Sparus auratus realizadas en el laboratorio del Mar Menor del Instituto Español de Oceanografía. Boletín Del Instituto Español de Oceanografía. 239:1-54.

Oettinger M. A., Schatz D. G., Gorka C., Baltimore D. (1990) RAG-1 and RAG-2, adjacent genes that synergistically activate V(D)J recombination. Science. 248:1517-1523.

Ogawa K.,Yokoyama H. (2001) Emaciation disease of cultured tiger puffer Takifugu rubripes. Bull Nat Res Inst Aquacult. 5:65-70.

Okamura B., Gruhl A., Bartholomew J. L. (2015) An introduction to myxozoan evolution, ecology and development, in: Okamura B., Gruhl A., and Bartholomew J. L. (Eds.) Myxozoan Evolution, Ecology and Development. Springer International, Switzerland. pp. 1-20.

Ortega A., Ros J. (1973) Primeras experiencias sobre cultivos de peces en el mar menor. Boletín Del Instituto Español de Oceanografía. 163:1-20.

Padrós F., Palenzuela O., Hispano C., Tosas O., Zarza C., Crespo S., Álvarez-Pellitero P. (2001a) Myxidium leei (Myxozoa) infections in aquarium-reared mediterranean fish species. Dis Aquat Org. 47:57-62.

Padrós F., Zarza C., Crespo S. (2001b) Histopathology of cultured sea bream Sparus aurata infected with sanguinicolid trematodes. Dis Aquat Org. 44:47-52.

Palenzuela O. (2006) Myxozoan infections in mediterranean mariculture. Parassitologia. 48:27-29.

Palenzuela O., Redondo M. J., Cali A., Takvorian P. M., Alonso-Naveiro M., Álvarez-Pellitero P., Sitjà-Bobadilla A. (2014) A new intranuclear microsporidium, Enterospora nucleophila n. sp., causing an emaciative syndrome in a piscine host (Sparus aurata), prompts the redescription of the family Enterocytozoonidae. Int J Parasitol. 44:189203.

Papapanagiotou E. P., Trilles J. P. (2001) Cymothoid parasite Ceratothoa parallela inflicts great losses on cultured gilthead sea bream Sparus aurata in Greece. Dis Aquat Org. 45:237-239.

Paperna I. (1980) Amyloodinium ocellatum (Brown, 1931) (Dinoflagellida) infestations in cultured marine fish at Eilat, Red Sea: Epizootiology and pathology. J Fish Dis. 3:363-372.

Parra D., Takizawa F., Sunyer J. O. (2013) Evolution of B cell immunity. Annu Rev Anim Bioscience. 1:65-97.

Press C. M., Evensen O. (1999) The morphology of the immune system in teleost fishes. Fish Shellfish Immunol. 9:309-318.

Pulsford A., Matthews R. A. (1991) Macrophages and giant cells associated with a microsporidian parasite causing liquefaction of the skeletal muscle of the Norway pout, Trisopterus esmarkii (Nilsson). J Fish Dis. 14:67-78.

Quiroga M. I., Redondo M. J., Sitjà-Bobadilla A., Palenzuela, O., Riaza A., Macias A., Vázquez S., Pérez A., Nieto J. M., Álvarez-Pellitero P. (2006) Risk factors associated with Enteromyxum scophthalmi (Myxozoa) infection in cultured turbot, Scophthalmus maximus (L.). Parasitology. 133:433-442.

Rajan B., Løkka G., Koppang E. O., Austbø L. (2017) Passive immunization of farmed fish. J Immunol. 198:4195-4202. 
Rakers S., Niklasson L., Steinhagen D., Kruse C., Schauber J., Sundell K., Paus R. (2013) Antimicrobial peptides (AMPs) from fish epidermis: Perspectives for investigative dermatology. J InvestDermatol. 133:1140-1149.

Rangel L. F., Cech G., Szekely C., Santos M. J. (2011) A new actinospore type Unicapsulactinomyxon (Myxozoa), infecting the marine polychaete, Diopatra neapolitana (Polychaeta: Onuphidae) in the Aveiro Estuary (Portugal). Parasitology. 138:698-712.

Redondo M. J., Palenzuela O., Álvarez-Pellitero, P. (2004) Studies on transmission and life cycle of Enteromyxum scopthalmi (Myxozoa), an enteric parasite of turbot Scophthalmus maximus. Folia Parasitol. 51:188-198.

Redondo M. J., Palenzuela O., Riaza A., Macias A., Álvarez-Pellitero P. (2002) Experimental transmission of Enteromyxum scophthalmi (Myxozoa), an enteric parasite of turbot Scophthalmus maximus. J Parasitol. 88:482-488.

Reite O. B. (1998) Mast cells eosinophilic granule cells of teleostean fish: A review focusing on staining properties and functional responses. Fish Shellfish Immunol. 8:489-513.

Reite O. B., Evensen O. (2006) Inflammatory cells of teleostean fish: A review focusing on mast cells/eosinophilic granule cells and rodlet cells. Fish Shellfish Immunol. 20:192-208.

Reite O. B., Evensen O. (1994) Mast cells in the swimbladder of atlantic salmon Salmo salar: Histochemistry and responses to compound 48/80 and formalin-inactivated Aeromonas salmonicida. Dis Aquat Org. 20:95-100.

Riera R. M., Pérez-Martínez D., Castillo-Ferrer C. (2016) Innate immunity in vertebrates: An overview. Immunology. 148:125-139.

Rigos G., Christophilogiannis P., Yiagnisi M., Andriopoulou A., Koutsodimou M., Nengas I., Alexis M. (1999) Myxosporean infections in greek mariculture. Aquacult Int. 7:361-364.

Rigos G., Katharios P. (2009) Pathological obstacles of newly-introduced fish species in mediterranean mariculture: A review. Rev Fish Biol Fisher. 20:47-70.

Rijkers G. T., Frederix-Wolters E. M., van Muiswinkel W. B. (1980) The immune system of cyprinid fish. Kinetics and temperature dependence of antibody producing cells in carp (Cyprinus carpio). Immunology. 41:91-97.

Rintamäki-Kinnunen P., Bernardet J. F., Bloigu A. (1997) Yellow pigmented filamentous bacteria connected with farmed salmonid fish mortality. Aquaculture. 149:1-14.

Rothenberg E. V., Moore J. E., Yui M. A. (2008) Launching the T-cell-lineage developmental programme. Nat rev Immunol. 8:9-21.

Salinas I. (2015) The mucosal immune system of teleost fish. Biology. 4:525-539.

Sanders J. L., Lawrence C., Nichols D. K., Brubaker J. F., Peterson T. S., Murray K. N., Kent M. L. (2010) Pleistophora hyphessobryconis (Microsporidia) infecting zebrafish Danio rerio in research facilities. Dis Aquat Org. 91:47-56.

Sattler S. (2017) The role of the immune system beyond the fight against infection. Advances in Experimental Medicine and Biology. 1003:3-14.

Schatz D. G., Oettinger M. A., Schlissel M. S. (1992) V(D)J Recombination: Molecular biology and regulation. Annu Rev Immunol. 10:359-383.

Schroeder H. W., Cavacini L. (2010) Structure and function of immunoglobulins. J Allergy Clin Immunol. 125:41-52.

Secombes C. J., Fletcher T. C. (1992) The role of phagocytes in the protective mechanisms of fish. Annu Rev Fish Dis. 2:53-71.

Secombes C. J., Wang T. (2012) The innate and adaptive immune system of fish, in: Austin B. (Ed.) Infectious Disease in Aquaculture. Woodhead Publishing, Oxford, Philadelphia, USA. pp. 3-68.

Sekiya M., Setsuda A., Sato H., Song K., Han J. K., Kim G. J., Yeo I. (2016) Enteromyxum leei (Myxosporea: Bivalvulida) as the cause of myxosporean emaciation disease of farmed olive flounders (Paralichthys olivaceus) and a turbot (Scophthalmus maximus) on Jeju island, Korea. Parasitol Res. 115:4229-4237.

Sepulcre M. P., Pelegrin P., Mulero V., Meseguer J. (2002) Characterisation of gilthead seabream acidophilic granulocytes by a monoclonal antibody unequivocally points to their involvement in fish phagocytic response. Cell Tissue Res. 308:97-102. 
Sfacteria A., Brines M., Blank U. (2015) The mast cell plays a central role in the immune system of teleost fish. Mol Immunol. 63:3-8.

Shaw R. W., Kent M. L. (1998) Modes of transmission of Loma salmonae (Microsporidia). Dis Aquat Org. 33:151-156.

Shinn A. P., Pratoomyot J., Bron J. E., Paladini G., Brooker E. E., Brooker A. J. (2015) Economic costs of protistan and metazoan parasites to global mariculture. Parasitology. 142:196-270.

Sindermann C. J. (1987) Effects of parasites on fish populations: Practical considerations. Int J Parasitol. 17:371-382.

Sitjà-Bobadilla A., Álvarez-Pellitero P. (1995) Light and electron-microscopic description of Polysporoplasma n. g. (Myxosporea, Bivalvulida), Polysporoplasma sparis n. sp. from Sparus aurata (L.) and Polysporoplasma mugilis n. $\mathrm{sp}$. from Liza aurata L. Eur J Protistol. 31:77-89.

Sitjà-Bobadilla A., Álvarez-Pellitero P. (2001) Leptotheca sparidarum n. sp (Myxosporea: Bivalvulida), a parasite from cultured common dentex (Dentex dentex L.) and gilthead sea bream (Sparus aurata L.) (Teleostei: Sparidae). J Eukaryot Microbiol. 48:627-639.

Sitjà-Bobadilla A., Calduch-Giner J., Saera-Vila A., Palenzuela O., Álvarez-Pellitero P., Pérez-Sánchez J. (2008) Chronic exposure to the parasite Enteromyxum leei (Myxozoa: Myxosporea) modulates the immune response and the expression of growth, redox and immune relevant genes in gilthead sea bream, Sparus aurata L. Fish Shellfish Immunol. 24:610-619.

Sitjà-Bobadilla A., Diamant A., Palenzuela O., Álvarez-Pellitero P. (2007) Effect of host factors and experimental conditions on the horizontal transmission of Enteromyxum leei (Myxozoa) to gilthead sea bream, Sparus aurata L., and european sea bass, Dicentrarchus labrax (L.). J Fish Dis. 30:243-250.

Sitjà-Bobadilla A., Gil-Solsona R., Estensoro I., Piazzon M. C., Martos-Sitcha J. A., Picard-Sánchez A., Fuentes J., Sancho J. V., Calduch-Giner J. A., Hernández F., Pérez-Sánchez J. (2019) Disruption of gut integrity and permeability contributes to enteritis in a fish-parasite model: A story told from serum metabolomics. Parasite Vector. 12:486.

Sitjà-Bobadilla A., Palenzuela O. (2012) Enteromyxum species, in: Woo P. T. K., Buchmann K. (Eds.) Fish Parasites: Pathology and Protection. CAB International, Oxfordshire UK. pp. 163-176.

Sitjà-Bobadilla A., Palenzuela O., Álvarez-Pellitero P. (1996) Light microscopic description of Eimeria sparis sp. nov. and Goussia sparis sp. nov. (Protozoa: Apicomplexa) from Sparus aurata L. (Pisces: Teleostei). Parasitol Res. 82:323-332.

Stentiford G. D., Feist S. W., Stone D. M., Bateman K. S., Dunn A. M. (2013) Microsporidia: Diverse, dynamic, and emergent pathogens in aquatic systems. Trends Parasitol. 29:567-578.

Stentiford G. D., Sritunyalucksana K., Flegel T. W., Williams B. A. P., Withyachumnarnkul B., Itsathitphaisarn O., Bass D. (2017) New paradigms to help solve the global aquaculture disease crisis. Plos Pathog. 13:e1006160.

Subasinghe R., Soto D., Jia J. (2009) Global aquaculture and its role in sustainable development. Rev Aquacult. $1: 2-9$.

Sundberg L. R., Ketola T., Laanto E., Kinnula H., Bamford J., Penttinen R., Mappes J. (2016) Intensive aquaculture selects for increased virulence and interference competition in bacteria. P Roy Soc B -Biol Sci. 283:20153069.

Tavares-Dias M., Martins M. (2017) An overall estimation of losses caused by diseases in the brazilian fish farms. J Parasitic Dis. 41:913-918.

Temmink J. H. M., Bayne C. J. (1987) Ultrastructural characterization of leucocytes in the pronephros of carp (Cyprinus carpio, L.). Dev Comp Immunol. 11:125-137.

Theisen J., Nehra D., Citron D., Johansson J., Hagen J., Crookes P., DeMeester S., Bremner C., Demeester T., Peters J. (2012) Suppression of gastric acid secretion in patients with gastroesophageal reflux disease results in gastric bacterial overgrowth and deconjugation of bile acids. J Gastrointes Surg. 4:50-54.

Tonegawa S. (1983) Somatic generation of antibody diversity. Nature. 302:575-581.

Tops S., Curry A., Okamura B. (2005) Diversity and systematics of the Malacosporea (Myxozoa). Invertebr Biol. 124:285-295. 
Tort L., Balasch J. C., MacKenzie S. (2003) Fish Immune System. A Crossroads between Innate and Adaptive Response. Inmunologia. 22:277-286.

Trouillier A., El-Matbouli M., Hoffmann R. W. (1996) A new look at the life-cycle of Hoferellus carassii in the goldfish (Carassius auratus auratus) and its relation to kidney enlargement disease (KED). Folia Parasitol. 43:173-187.

Vávra J., Ronny Larsson J. I. (2014) Structure of Microsporidia, in: Weiss L. M., Becnel J. J. (Eds.) Microsporidia: Pathogens of Opportunity. Wiley-Backwell, Ames, Iowa, USA. pp. 1-70.

Vossbrinck R. C, Debrunner-Vossbrinck A. B. (2005) Molecular phylogeny of the Microsporidia: Ecological, ultrastructural and taxonomic considerations. Folia Parasitol. 52:131-142.

Waite R., Beveridge M., Brummett R., Chaiyawannakarn N., Kaushik S., Mungkung R., Nawapakpilai S., Phillips M. (2014) Improving productivity and environmental performance of aquaculture. Technical Report, World Resources Institute, Washington, USA. pp. 1-60.

Wang X., Tan X., Peijun Z., Zhang Y., Xu P. (2014) Recombination-activating gene 1 and 2 (RAG1 and RAG2) in flounder (Paralichthys olivaceus). J Bioscience. 39:849-858.

Weissenberg R. (1968) Intracellular development of the microsporidan Glugea anomala moniez in hypertrophying migratory cells of the fish Gasterosteus aculeatus L., an example of the formation of 'xenoma' tumors. J Protozool. 15:44-57.

Willett C. E., Zapata A. G., Hopkins N., Steiner L. A. (1997) Expression of zebrafish RAG genes during early development identifies the thymus. Dev Biol. 182:331-341.

Wolf K., Markiw M. E. (1984) Biology contravenes taxonomy in the Myxozoa: New discoveries show alternation of invertebrate and vertebrate hosts. Science. 225:1449-1452.

Yanagida T., Nomura Y., Kimura T., Fukuda Y., Yokoyama H., Ogawa K. (2004) Molecular and morphological redescriptions of enteric myxozoans, Enteromyxum leei (formerly Myxidium sp tii) and Enteromyxum fugu comb. n. (syn. Myxidium fugu) from cultured tiger puffer. Fish Pathol. 39:137-143.

Yanagida T., Sameshima M., Nasu H., Yokoyama H., Ogawa K. (2006) Temperature effects on the development of Enteromyxum spp. (myxozoa) in experimentally infected tiger puffer, Takifugu rubripes (Temminck \& Schlegel). J Fish Dis. 29:561-567.

Yanagida T., Palenzuela O., Hirae T., Tanaka S., Yokoyama H., Ogawa K. (2008) Myxosporean emaciation disease of cultured red sea bream Pagrus major and spotted knifejaw Oplegnathus punctatus. Fish Pathol. 43:45-48.

Yasuda H., Ooyama T., Iwata K., Tun T., Yokoyama H., Ogawa K. (2002) Fish-to-fish transmission of Myxidium spp. (Myxozoa) in cultured tiger puffer suffering from emaciation disease. Fish Pathol. 37:29-33.

Yasuda H., Ooyama T., Nakamura A., Iwata K., Palenzuela O., Yokoyama H. (2005) Occurrence of the myxosporean emaciation disease caused by Enteromyxum leei in cultured japanese flounder Paralichthys olivaceus. Fish Pathol. 40:175-180.

Zapata A. (1979) Ultrastructural study of the teleost fish kidney. Dev Comp Immunol. 3:55-65.

Zhang Y. A., Salinas I., Li J., Parra D., Bjork S., Xu Z., LaPatra S. E., Bartholomew J., Sunyer J. O. (2010) IgT, a primitive immunoglobulin class specialized in mucosal immunity. Nat Immunol. 11:827-835.

Zhu Y., Huang B., Shi J. (2016) Fas ligand and lytic granule differentially control cytotoxic dynamics of natural killer cell against cancer target. Oncotarget. 7:47163-47172. 

70 
This PhD thesis focuses on the study of two enteric parasites that affect cultured gilthead sea bream (Sparus aurata): Enteromyxum leei (Myxozoa), and Enterospora nucleophila (Microsporidia).

E. leei is a fish endoparasite, which dwells among enterocytes of the intestinal epithelium, producing chronic enteritis in gilthead sea bream. This infection not only affects fish health, but also causes significant losses in the aquaculture industry. The control of enteromyxosis is especially difficult due its horizontal fish-to-fish transmission and the lack of an in vitro culture, which greatly hampers molecular studies driven towards the development of quick diagnostics techniques and therapeutic treatments. Low water temperature has been related with lower prevalence of infection in fish. However, before this thesis, there were no specific studies on the effect of the time of exposure to the parasite and the temperature on the ability of the parasite to infect, and the response of the fish, particularly in terms of protective immunity. Also, until now, no immune memory against E. leei had been demonstrated. Therefore, thorough integrative studies on the immune response of gilthead sea bream, on the parasite interaction with the fish host, as well as on the immune mechanisms triggered by the parasite and their contribution to host protection are key to manage this disease in aquaculture. All the generated knowledge, due to the broad host range of E. leei, which includes more than 60 fish species and potential invertebrate host(s), will have a paramount impact for the control of this disease worldwide.

E. nucleophila is an endoparasite that can be found either in intranuclear or cytoplasmatic location in the host cells. Its microscopic size hampers a quick and accurate diagnosis, since the available techniques like in situ hybridization or calcofluor staining may not work in mild infections, or may detect only some type of stages. E. nucleophila was first described in 2014 as an important emergent pathogen in aquaculture, and little was known about its pathogenicity in gilthead sea bream. So far, no in vivo transmission model or in vitro culture have been established, and the studies depend on natural outbreaks in Mediterranean gilthead sea bream farms.

In this context, the present thesis has two different parasite targets and a common host, with a final aim: to better understand these parasitic enteric diseases of gilthead sea bream, in order to improve the management and fish health in aquaculture. Due to the different level of previous knowledge of both parasites, the new generated information starts from a different initial point. The availability of many studies related to E. leei pathogenicity, diagnosis, host-parasite interactions, and standardized in vivo transmission protocols allowed to perform a more in-depth and specific research on the fine-tuning of experimental infections and the immune mechanisms triggered by this parasite in the host, with a special focus on acquired immunity. All this new knowledge, together with the production of a parasite transcriptome, will be finally applied to target molecules to develop improved diagnostic and therapeutic techniques. On the other hand, as E. nucleophila was a recently described emerging parasite, studies were very scarce. Thus, in this thesis we aimed to perform a proper description of the pathology and to study the horizontal transmission of this parasite to establish an in vivo model that will allow future in-depth studies of the disease. 


\section{The specific objectives of this thesis are:}

- To fine-tune the parameters for E. leei experimental effluent infection, the route that most accurately mimics natural transmission in a fish farm. In this context, the aim was to evaluate the minimum time of exposure to achieve infection, and the influence of variables such as temperature and fish density.

- To determine the basis of the protective mechanisms involved in gilthead sea bream surviving a first exposure to E. leei and re-exposed to the parasite. The aim was to study innate and adaptive responses in re-exposed animals, compared to animals challenged for the first time with the parasite.

- To demonstrate the protective role of specific antibodies against enteromyxosis in gilthead sea bream by passive immunization.

- To characterize the immunoglobulin response produced against E. leei, analysing and comparing the intestinal IgM and IgT repertoire in naïve and resistant animals re-exposed to the parasite.

- To generate an E. leei transcriptome to seek diagnostic and therapeutic targets against the parasite.

- To identify immunogenic E. leei proteins to serve as vaccine candidates.

- To describe the pathological effects of E. nucleophila in naturally infected gilthead sea bream, its location within the host, and the cellular immune response evoked.

- To develop an in vivo model for the experimental transmission of E. nucleophila. 


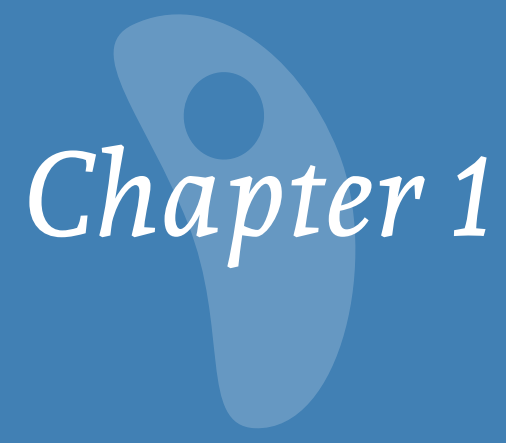

\title{
Acquired protective immune response in a fish-myxozoan model encompasses specific antibodies and inflammation resolution
}

\author{
Amparo Picard-Sánchez; Itziar Estensoro; Raquel Del Pozo; \\ M. Carla Piazzon; Oswaldo Palenzuela; Ariadna Sitjà-Bobadilla \\ INSTITUTO DE ACUICULTURA TORRE DE LA SAL \\ CONSEJO SUPERIOR DE INVESTIGACIONES CIENTÍFICAS (IATS-CSIC), \\ Torre de la Sal s/n 12595 Castellón Spain
}

(Fish Shellfish Immunol. 90:349-362, 2019) 
Control of enteric parasitic diseases of farmed gilthead sea bream 


\subsection{ABSTRACT}

The myxozoan parasite Enteromyxum leei causes chronic enteritis in gilthead sea bream (Sparus aurata) leading to intestinal dysfunction. Two trials were performed in which gilthead sea bream that had survived a previous infection with E. leei (SUR), and naïve (NAI), were exposed to water effluent containing parasite stages. Humoral factors (total IgM and IgT, specific anti-E. leei IgM, total serum peroxidases), histopathology and gene expression were analysed. Results showed that SUR maintained high levels of specific anti-E. leei IgM (up to 16 months), expressed high levels of immunoglobulins at the intestinal mucosa, particularly the soluble forms, and were resistant to re-infection. Their acquired-type response was complemented by other immune effectors locally and systemically, like cell cytotoxicity (high granzyme A expression), complement activity (high $c 3$ and fucolectin expression), and serum peroxidases. In contrast to NAI, SUR displayed a post-inflammatory phenotype in the intestine and head kidney, characteristic of inflammation resolution (low il1 $\beta$, high il10 and low hsp90 $\alpha$ expression).

\section{Keywords}

Acquired immune response, fish IgM, Sparus aurata, Enteromyxum leei, parasite resistance, gene expression. 


\subsection{INTRODUCTION}

Aquaculture production is constantly increasing, reaching 110 million tons globally, with a value of over 210 billion Euros in 2016 (FAO, 2018). However, infectious diseases threaten its future and sustainability. The most common etiological agents in aquaculture are bacteria and viruses, followed by parasites. Parasite infections are favoured by fish farming conditions, often in over-crowded cages, and with stressful handling procedures, which also contribute to the propagation of opportunistic pathogens, provoking important economic losses (Shinn et al., 2015).

The myxozoan clade, which belongs to the phylum Cnidaria, comprises more than 2,180 species spread worldwide, most of which are fish endoparasites, infecting any tissue and host organ (Okamura et al., 2015). They have a large impact on freshwater and marine fish production (Canning \& Okamura, 2004) since there are no available effective control measures, such as vaccines or commercial treatments. Enteromyxum leei is a serious risk to gilthead sea bream (Sparus aurata) aquaculture due to its high rate of horizontal transmission and its high pathogenic potential (Diamant, 1992). This myxozoan is a histozoic parasite that dwells between gut epithelial cells, causing different degrees of anorexia, delayed growth with weight loss, cachexia, reduced marketability and increased mortality (Sitjà-Bobadilla \& Palenzuela, 2012). Its typical cell-in-cell division leads to the formation of mature proliferative stages that are capable of releasing new daughter cells, which invade the host intestine following a posterior-anterior pattern (Cuadrado et al., 2008). In advanced gilthead sea bream infections with $E$. leei, the intestine displays hypertrophy of the lamina propria-submucosa and loss of the epithelial palisade structure, together with an intense local inflammatory response (Cuadrado et al., 2008, 2010; Freurance et al., 2008; Sitjà-Bobadilla \& Palenzuela, 2012). These intestinal changes heavily impair nutrient absorption reducing farming performances. Nowadays, E. leei constitutes a threat for many other cultured sparids, such as sharpsnout sea bream, Diplodus puntazzo (Athanassopoulou et al., 1999); black spot seabream, Pagellus bogaraveo (Mladineo, 2003); common sea bream, Pagrus pagrus (Diamant, 1995); and red sea bream, Pagrus major (le Breton $\&$ Marques, 1995).

Fish possess a complete immune system in which innate (natural) and adaptive (acquired) immunity are integrated, and mechanisms of immunologic specificity and memory are developed. The importance of mucosal interfaces in the triggering of antigen responses has been acknowledged in this primitive vertebrate clade (Parra et al., 2015; Rombout et al., 2014). In the last decade, studies on fish immunity 
are shedding some light on the immune effectors involved in the response to some myxozoan infections (Âlvarez-Pellitero, 2008; Gómez et al., 2014; Sitjà-Bobadilla et al., 2015, 2016), but a long road lies ahead before therapeutics and vaccines will be available.

Immune response to myxozoans is highly species- and tissue-specific. The hostparasite encounter usually takes place at the mucosal surfaces, and thus, the first line of interactions and responses against myxozoa originate at the mucosal epithelia orchestrated locally by the mucosa-associated lymphoid tissue (MALT). Some myxozoan species reside only transitorily in mucosal epithelia, their route of entry into the host before they spread and reach their target sites. This is the case of some Sphaerospora spp. (Eszterbauer et al., 2013), Tetracapsuloides bryosalmonae (Grabner et al., 2010; Holzer et al., 2006), and Myxobolus cerebralis (Sarker et al., 2015). An inflammatory reaction is common at the target tissues of histozoic myxozoans (Sitjà-Bobadilla et al., 2015), and by contrast, infection does not elicit any immune response while the parasite infects or moves along some immuneprivileged sites, as the nerves in the case of $M$. cerebralis and the testes in the case of S. testicularis (Sitjà-Bobadilla, 2008a).

In gilthead sea bream enteromyxosis, serum immunoglobulins, lysozyme, peroxidases and complement are involved in the humoral response (Cuesta et al., 2006a; Estensoro et al., 2012a; Piazzon et al., 2016a; Sitjà-Bobadilla et al., 2008b), and $B$ cells, $T$ cells, mast cells and melanomacrophages act locally and systemically during the inflammatory response (Estensoro et al., 2014; Piazzon et al., 2018). The mucin-constituted mucus barrier overlying the epithelia is the attachment site for the parasite before it penetrates the tissue and proliferates or spreads. Mucin composition and expression, and mucus-secreting goblet cell distribution are also modulated during enteromyxosis (Estensoro et al., 2012b, 2013b; Fleurance et al., 2008; Pérez-Sánchez et al., 2013; Redondo et al., 2010). Chronic exposure to the parasite stimulated expression of genes related to interferon signalling and antigen processing and presentation in the intestine of exposed non-parasitized fish, which may point to the local triggering of immune resistance mechanisms against the infection (Davey et al., 2011). An increase in the splenic melanomacrophage centres during gilthead sea bream enteromyxosis may also indicate the onset of an acquired immune response(Estensoro et al., 2014; Fleurance et al., 2008). Interleukin (IL) expression during gilthead sea bream enteromyxosis was modulated from a pro-inflammatory to an anti-inflammatory profile, and this shift was apparently driven by the up-regulation of il10 (Pérez-Cordón et al., 2014). More recently, the involvement of a cytotoxic response in the clearance of the parasite was suggested from the higher expression of $c d 8$ receptors and cytotoxic molecules in exposed non-parasitized fish intestines (Piazzon et al., 2018). 
Resistant fish strains or acquired protection was reported for some myxozoan infections, as in the case of Kudoa thyrsites (Jones et al., 2016), T. bryosalmonae (Ferguson \& Ball, 1979) and Ceratomyxa shasta (Bartholomew, 1998) infecting salmonids, or in E. leei affecting some sparid species (Golomazou et al., 2006; Yanagida et al., 2008). Fish recovered from some myxozoan infections are less susceptible to reinfection, however, acquired immune mechanisms involved in resistance upon re-exposure to myxozoans have been studied in few cases. Specific antibodies conferred resistance against E. scophthalmi in turbot (SitjàBobadilla et al., 2007b). The severity of infection with $K$. thyrsites was decreased in re-exposed Atlantic salmon, which exhibited an acquired protective immune response mounted on antigen-presenting monocyte/macrophage and dendritic cells, along with $\mathrm{B}$ and $\mathrm{T}$ cells in the muscle tissue (Braden et al., 2018). Rainbow trout re-exposed to T. bryosalmonae developed immune protection through the increase of circulating $\operatorname{IgM}^{+} \mathrm{B}$ cells and up-regulated mRNA levels of secretory IgM in the posterior kidney (Bailey et al., 2017). However, there are no previous studies on immune response upon re-challenge with E. leei.

The aim of this study was to determine the bases of the protective mechanisms involved in gilthead sea bream surviving a first exposure to E. leei and re-exposed to the parasite. We focused on innate and adaptive immune parameters in order to elucidate the differential response of these re-exposed animals, compared to animals challenged for the first time with the parasite. Special attention was given to the role played by immunoglobulins and by the inflammatory response at the mucosal interface.

\subsection{MATERIALS AND METHODS}

\subsubsection{Fish and experimental infections}

Specific-pathogen-free (SPF) and clinically healthy gilthead sea bream juvenile specimens from a commercial fish farm were kept in $5 \mu \mathrm{m}$-filtered and UV irradiated sea water (salinity $37.5 \mathrm{~g} / \mathrm{L}$ ) at temperatures between $18^{\circ} \mathrm{C}$ and $27^{\circ} \mathrm{C}$, with natural photoperiod at our latitude $\left(40^{\circ} 5^{\prime} \mathrm{N} ; 0^{\circ} 10^{\prime} \mathrm{E}\right)$. The SPF status was confirmed by qPCR according to the protocol described in section 1.2.2. Fish were fed ad libitum a commercial diet (BioMar, Palencia, Spain). Animals were kept according to the Guidelines of the European Union Council (Directive 2010/63/ EU) and the Spanish RD 53/2013. All efforts were made to minimize suffering of the fish used for the experiments in accordance with national (Royal Decree RD1201/2005, for the protection of animals used in scientific experiments) and the current European Union legislation (86/609/EU) and the CSIC National Committee on Bioethics under approval number 151-2014. Two challenge trials with E. leei 
were performed at the facilities of IATS-CSIC (Castellón, Spain): T1, started in February and lasted 175 days (water temperature range $18^{\circ} \mathrm{C}-26.1^{\circ} \mathrm{C}$ ) and $\mathrm{T} 2$ started in June, lasted 86 days (water temperature range $22.9^{\circ} \mathrm{C}-27^{\circ} \mathrm{C}$ ). The reason for having two trials was mainly due to the low prevalence of infection found in T1. T2 was performed at higher water temperatures to ensure higher infection rates. Differences in sampling dates between trials were due to the faster progression of infection in T2, probably as a result of the different starting temperature. For clarity, a summary of the timings and experimental groups can be found in Table 1. In both trials, fish were challenged with E. leei by exposure to infected effluent, mimicking the natural route of infection. Briefly, it consisted of tanks holding recipient fish (RCPT) receiving water effluent from a donor tank holding E. leeiinfected gilthead sea bream, as previously described (Sitjà-Bobadilla et al., 2007a). Heavily infected donor fish were selected using a non-lethal diagnostic technique described in section 1.2.2. The renewal of the water in the effluent system was kept to a minimum to ensure longer exposure to the parasite but without affecting water quality. The effluent exposure was not interrupted until the final sampling.

In both trials, two groups of RCPT fish were used. One group consisted of surviving fish (SUR), recovered from two previous independent experimental E. leeiinfections. For T1, 20 SUR adult fish (initial mean body weight: $607 \mathrm{~g}$ ) were used. In T2 the number of SUR fish was $24(175 \mathrm{~g})$. These animals were routinely tested by the non-lethal molecular diagnosis described in section 1.2.2. All SUR fish had yielded a $100 \%$ prevalence of infection (9 weeks post-exposure) and later on, tested negative for the presence of the parasite at 16 (T1) and 9 (T2) months post-exposure. Thus, all SUR animals had recovered from an established infection. The second group consisted of naïve gilthead sea bream (NAI), never exposed to the parasite. Twenty NAI fish were used in, both, T1 and T2 (initial mean body weight 95 and $246 \mathrm{~g}$, respectively). For both trials, SUR and NAI fish were individually tagged with passive integrated transponders (PIT-tags) and equally distributed into two replicated-500 L RCPT-tanks. All NAI and SUR fish were obtained from the same fish farm, and were held in the same conditions until the trials were carried out. In T2 NAI and SUR fish belonged to same stock and the only difference was the previous exposure to the parasite, which was reflected in the difference in weight. Thus, gene expression analyses were only performed in T2 to avoid differences due to age or genetic background. 
Table 1. Experimental groups and sampling details of the two Enteromyxum leei transmission trails (T1 and T2) to gilthead sea bream (Sparus aurata). NAI (naïve), SUR (surviving), dpe (days post exposure), NL-PCR (nonlethal rectal mucosa probe for PCR diagnosis), HIS (tissue sample for histology), GE (tissue sample for gene expression), HK (head kidney), AI (anterior intestine), MI (middle intestine), PI (posterior intestine).

\begin{tabular}{|c|c|c|c|c|c|c|c|}
\hline & \multicolumn{4}{|c|}{$\mathbf{T 1}$} & \multicolumn{3}{|c|}{ T2 } \\
\hline $\begin{array}{l}\text { Initial water } \\
\text { temperature }\end{array}$ & \multicolumn{4}{|c|}{$18^{\circ} \mathrm{C}$} & \multicolumn{3}{|c|}{$22.8^{\circ} \mathrm{C}$} \\
\hline $\begin{array}{l}\text { Mean water } \\
\text { temperature }\end{array}$ & \multicolumn{4}{|c|}{$19.6^{\circ} \mathrm{C}$} & \multicolumn{3}{|c|}{$24.3^{\circ} \mathrm{C}$} \\
\hline $\begin{array}{l}\text { Sampling } \\
\text { time (dpe) }\end{array}$ & 0 & 66 & 105 & 175 & 0 & 61 & 86 \\
\hline $\begin{array}{l}\text { Samples } \\
\text { taken }\end{array}$ & $\begin{array}{l}\text { NL-PCR, } \\
\text { blood }\end{array}$ & $\begin{array}{c}\text { NL-PCR, } \\
\text { blood }\end{array}$ & $\begin{array}{c}\text { NL-PCR, } \\
\text { blood }\end{array}$ & $\begin{array}{l}\text { HIS (AI, } \\
\text { MI, PI), } \\
\text { blood }\end{array}$ & $\begin{array}{l}\text { NL-PCR, } \\
\text { blood }\end{array}$ & $\begin{array}{c}\text { NL-PCR, } \\
\text { blood }\end{array}$ & $\begin{array}{l}\text { HIS (AI, MI, PI), } \\
\text { GE (HK, AI, PI), } \\
\text { blood }\end{array}$ \\
\hline Fish group & \multicolumn{2}{|c|}{ NAI } & \multicolumn{2}{|c|}{ SUR } & \multicolumn{2}{|c|}{ NAI } & SUR \\
\hline Fish number & \multicolumn{2}{|c|}{20} & \multicolumn{2}{|c|}{20} & \multicolumn{2}{|c|}{20} & 24 \\
\hline $\begin{array}{l}\text { Initial } \\
\text { weight (g) }\end{array}$ & \multicolumn{2}{|c|}{95} & \multicolumn{2}{|c|}{607} & \multicolumn{2}{|c|}{246} & 175 \\
\hline
\end{tabular}

\subsubsection{Samplings and parasite diagnosis}

In all samplings, fish were starved for two days before sampling and blood samples $(1 \mathrm{ml})$ from SUR and NAI were taken from the caudal vessels by puncture with heparinized sterile needles. After overnight clotting at $4^{\circ} \mathrm{C}$ and centrifugation at $3,000 \times g$ for $30 \mathrm{~min}$, sera were recovered and maintained at $-80^{\circ} \mathrm{C}$ until further use. In the intermediate non-lethal (NL) samplings, fish were additionally sampled for parasite diagnosis by a non-lethal probe of the rectal mucosa with a cotton swab and PCR was carried out with specific primers for E. leei 18S rRNA gene, as previously described (Palenzuela \& Bartholomew, 2002; Sitjà-Bobadilla $\&$ Palenzuela, 2012). This NL-method was also used to determine the historical infection status of the SUR fish described above. At the final lethal samplings, all SUR and NAI fish were killed by overexposure to anaesthesia (MS-222, $0.1 \mathrm{~g} / \mathrm{L}$; Sigma). Head kidney, anterior and posterior intestine samples from all fish were taken in RNAlater (Qiagen) and kept at $-20^{\circ} \mathrm{C}$ for gene expression studies (final sampling of T2). Anterior, middle and posterior intestine samples from all fish were taken in 10\% buffered formalin for standard histological procedures at the final sampling of both trials. Infection intensity was semiquantitatively evaluated on Giemsa stained histological sections of anterior intestine (AI), middle intestine (MI) and posterior intestine (PI) following the ranges: low = 1-10; medium = 11-50; high $=51$ to $>100$ parasite stages per microscope field observation at 120x. A fish 
was considered positive for infection, when the parasite was found at least in one intestinal segment. Number of fish and type of samples taken at each time point are listed in Table 1. Fish that died outside the scheduled sampling points were checked post-mortem for the presence of the parasite and were no longer included in the results.

\subsubsection{Circulating antibody detection}

Total IgM in SUR and NAI serum samples was measured by ELISA. Briefly, 96- flatbottomed well microplates (Maxisorp, Nunc) were coated with $50 \mu \mathrm{l}$ of the gilthead sea bream sera diluted 1:3,000 in coating buffer (carbonate-bicarbonate buffer, $\mathrm{pH}$ 9.6) overnight at $4^{\circ} \mathrm{C}$. Between incubation steps, three successive washings with TTBS (20 mM Tris-HCl, $0.5 \mathrm{M} \mathrm{NaCl}$, pH 7.2 (TBS) with $0.05 \%$ Tween 20) and one with TBS were performed. A blocking incubation step was carried out with $5 \%$ skimmed milk in TBS for $2 \mathrm{~h}$ at $37^{\circ} \mathrm{C}$, before incubating with a custom-made rabbit polyclonal antibody (Ab) against gilthead sea bream IgM $(1: 80,000)$ (Palenzuela et al., 1996) for two further hours at $37^{\circ} \mathrm{C}$. Thereafter, goat anti-rabbit IgG horseradish peroxidase conjugate (Sigma) diluted 1:2,000 in TBS was added, incubated for $1 \mathrm{~h}$ at $37^{\circ} \mathrm{C}$ and the last washing performed. TMB peroxidase substrate (3,3',5,5'-tetramethylbenzidine solution $+\mathrm{H}_{2} \mathrm{O}_{2}$; Bio-Rad) was applied, incubated at room temperature in the dark with gentle shaking for $30 \mathrm{~min}$, and finally the reaction was stopped by addition of $1 \mathrm{~N} \mathrm{H}_{2} \mathrm{SO}_{4}$. The plates were then read at $450 \mathrm{~nm}$ with an automatic plate reader (Tecan Group Ldt.).

Total IgT in gilthead sea bream serum samples was analysed by ELISA as previously described (Piazzon et al., 2016a) using a custom-made anti-gilthead sea bream IgT $\mathrm{Ab}(1: 1,000)$.

The presence of specific IgM against E. leei in serum samples was immunohistochemically detected using paraffin embedded sections of E. leei-infected gilthead sea bream intestines obtained from previous and independent infection trials, following a protocol that can be described as an immunohistochemical sandwich ELISA. This method was chosen due to the unavailability of an optimized ELISA for this parasite. In addition, it has the advantage of providing information on the different parasite structures labelled by each serum. Briefly, tissue sections were deparaffinised and hydrated, endogenous peroxidase activity was quenched by incubation for 30 minutes in $3 \% \mathrm{H}_{2} \mathrm{O}_{2}$ and slides were blocked with 1.5\% normal goat serum (VECTOR Laboratories) for another $30 \mathrm{~min}$. The standard washing procedure consisted of $5 \mathrm{~min}$ successive immersions in TTBS and TBS between incubation steps, which were performed in a humid chamber at room temperature. Tissue sections were then incubated 
for $1 \mathrm{~h}$ with each individual SUR or NAI serum (1:25 in TBS 1\% bovine serum albumin; Sigma) and thereafter for one further hour with the rabbit polyclonal Ab against gilthead sea bream IgM (1:17,000) (Palenzuela et al., 1996). Finally, tissues were incubated with a biotinilated goat anti-rabbit Ab (VECTOR Labs.) for $1 \mathrm{~h}$ and the avidin-biotin-peroxidase complex (ABC; VECTOR Labs.) was applied for one further hour. Bound peroxidase was visualized by addition of 3,3'-diaminobezidine tetrahydrochloride chromogen (Sigma) and the reaction stopped after $2 \mathrm{~min}$ with deionized water. Tissue sections were subsequently counterstained with Gill's haematoxylin, dehydrated and mounted in di-N-butyl-phthalate in xylene. Each serum sample was tested in duplicate. Negative controls were carried out omitting the fish serum, the primary and secondary Abs or the ABC. Intensity of immunoreactivity of each fish serum against the parasite was evaluated by microscopic examination of the immunolabelled tissue sections according to a semiquantitative scale ranging from 0 to 6 (scaling: $0=$ no immunoreactivity with the parasite; 1 = very slight reactivity; 2 = slight reactivity; 3 = medium reactivity; $4=$ medium-intense reactivity; 5 = intense reactivity; $6=$ very intense reactivity).

\subsubsection{Total serum peroxidases}

Total serum peroxidases (PO) in SUR and NAI serum samples were measured in a plate assay following the procedure as previously described (Sitjà-Bobadilla et al., 2005). Briefly, individual sera diluted 1:20 in Hank's balanced salt solution were incubated in 96-well microplates (Nunc) with $50 \mu \mathrm{l}$ of TMB peroxidase substrate (Bio-Rad) (final volume $200 \mu \mathrm{l} /$ well). After 2 min incubation at room temperature in the dark with gentle shaking, the reaction was stopped by addition of $1 \mathrm{~N}_{2} \mathrm{SO}_{4}$. Then, plates were read at $450 \mathrm{~nm}$ with an automatic plate reader (Tecan Group Ldt.).

\subsubsection{Gene expression analysis}

\section{RNA isolation}

Total RNA from $100 \mathrm{mg}$ of AI, PI and head kidney (HK), of 8 individuals of each T2 group (SUR and NAI) obtained at the final sampling ( $86 \mathrm{dpe}$ ) was isolated by means of the MagMax-96 for Microarray Total RNA Isolation kit (Ambion, Applied Biosystems), following the manufacturer's instructions. Tissue homogenization was performed in Lysing Matrix D tubes (MP Biomedicals) with $1 \mathrm{ml}$ of TRI reagent using a FastPrep-24 homogenizer (MP Biomedicals, 2 cycles of $30 \mathrm{~s}$ at 6 $\mathrm{m} / \mathrm{s}$ ). RNA quantity and purity was determined by Nanodrop (Thermo Scientific). The 8 individuals selected for the NAI group were the ones with highest infection intensity at 86 dpe. The 8 SUR fish chosen were the ones showing highest serum 
immunoreactivity against $E$. leei at 0 dpe. The criteria for the targeted selection was our prediction based on previous results, that pre-exposure to the parasite confers resistance to re-infection based, at least in part, on the presence of specific antibodies.

\section{cDNA synthesis and amplification}

Prior to reverse transcription, 500 ng of RNA were treated with DNaseI amplification grade (Invitrogen) following the manufacturer's instructions. Five hundred ng of input RNA were reverse transcribed using the High-Capacity cDNA Archive Kit (Applied Biosystems) following the manufacturer's protocol $\left(10 \mathrm{~min}\right.$ at $25^{\circ} \mathrm{C}, 2 \mathrm{~h}$ at $37^{\circ} \mathrm{C}$, and $5 \mathrm{~min}$ at $85^{\circ} \mathrm{C}$ ).

\section{PCR array}

Real-time (RT) quantitative PCR was carried out using the CFX96 Connect ${ }^{\mathrm{TM}}$ Real-Time PCR Detection System (Bio-Rad) in a 96-well layout designed for simultaneously profiling the genes of interest for each tissue and individual. The primers used in this study (Supplementary Table 1) were selected to detect target genes characteristic of the specific responses to be studied. The primers were designed and/or checked for specificity by data mining of the gilthead sea bream transcriptomic database (http://nutrigroup-iats.org/seabreamdb/). All the primers were checked to have similar efficiency above $90 \%\left(\mathrm{R}^{2}>0.98\right)$. Each RT reaction of $20 \mu \mathrm{l}$ contained $3.3 \mathrm{ng}$ of total input RNA sample, 5×PyroTaq EvaGreen qPCR Mix Plus (Cultek Molecular Bioline) and specific primers at a final concentration of $0.45 \mu \mathrm{M}$. The PCR reaction conditions consisted of an initial step at $95^{\circ} \mathrm{C}$ for $3 \mathrm{~min}$, followed by 40 cycles of denaturation for $15 \mathrm{~s}$ at $95^{\circ} \mathrm{C}$ and annealing/extension for $60 \mathrm{~s}$ at $60^{\circ} \mathrm{C}$. The specificity of the reactions was verified by visual analysis of melting curves for each reaction performed. Fluorescence data acquired during the PCR extension phase were normalized by the delta-delta Ct method (Livak \& Schmittgen, 2001) using $\beta$-actin as a reference gene. This particular reference gene was chosen among several other candidates as the most stable among conditions in each tissue with the GeNorm software. To allow comparisons, all individual $\beta$-actin $\mathrm{Ct}$ values were verified to have differences lower than $1 \mathrm{Ct}$ value.

\subsubsection{Cluster analysis}

Partitioning cluster analysis was performed to evaluate the similarity of all individual fish used in the gene expression analysis. All the information available for each of the SUR $(n=8)$ and NAI $(n=8)$ fish used for the PCR array from T2 was used to perform K-means clustering. This includes individual biometric parameters (weight, length and condition factor), serum peroxidases, total serum IgM, total serum IgT and specific serum IgM levels for all three sampling points; individual 
infection status determined by NL-diagnostic in the intermediate sampling and by histological scoring in the final sampling; and the expression level of the 21 genes studied in the three tissues (head kidney, anterior and posterior intestine) in the final sampling. The raw data used for the cluster analysis are shown in Supplementary Table 2. Clustering was performed in R (v3.4.3) using the kmeans function with scaled data, $k=3$ and $n s t a r t=50$ to obtain stable results (R-Core-Team, 2007). Visualizations were performed using the factoextra R package (Kassambara \& Mundt, 2017).

\subsubsection{Statistics}

Data on specific serum IgM, total serum IgM, total serum IgT, serum PO and gene expression were analysed for statistically significant differences between SUR and NAI among sampling points by one-way analyses of variance (ANOVA-I) followed by Student-Newman-Keuls test. Data which failed the normality or equal variance test were analysed with Kruskal-Wallis ANOVA-I on ranks followed by Dunn's method. Differences were considered significant at a $p<0.05$. A Chi-squared test was run to assess whether having specific IgM against E. leei and being parasitized was dependent on the NAI/SUR condition.

\section{$1.3 \quad$ RESULTS}

\subsubsection{Parasite infections}

In T1 SUR fish, the parasite was only detectable at 66 dpe (15\% prevalence) and no infection was detectable at 105 and 175 dpe, whereas T1 NAI fish reached their maximum prevalence of infection (40\%) at the third sampling (105 dpe). At the last sampling point (175 dpe), prevalence of infection of NAI dropped to $20 \%$ (Table 2). Giemsa stained sections obtained at the last sampling allowed to depict the intensity and extension of the infection along the intestinal tract. NAI fish showed medium infection intensities at the PI, consisting mainly of trophozoites with secondary (S) and tertiary cells (T), whereas AI and MI segments had low infection intensity, with mostly single cell trophozoites (primary (P) cells) (Figure 1). Inflammatory infiltrates and hypertrophy of the intestinal submucosa were often observed in NAI fish. By contrast, no parasite stages were detected in SUR fish. Scattered macrophage-like cells with engulfed cell debris in the epithelium, infiltrated lymphocyte-like cells close to the basal membrane, and eosinophilic granular cell aggregates in the lamina propria-submucosa were often seen in SUR intestines (Figure 1). 

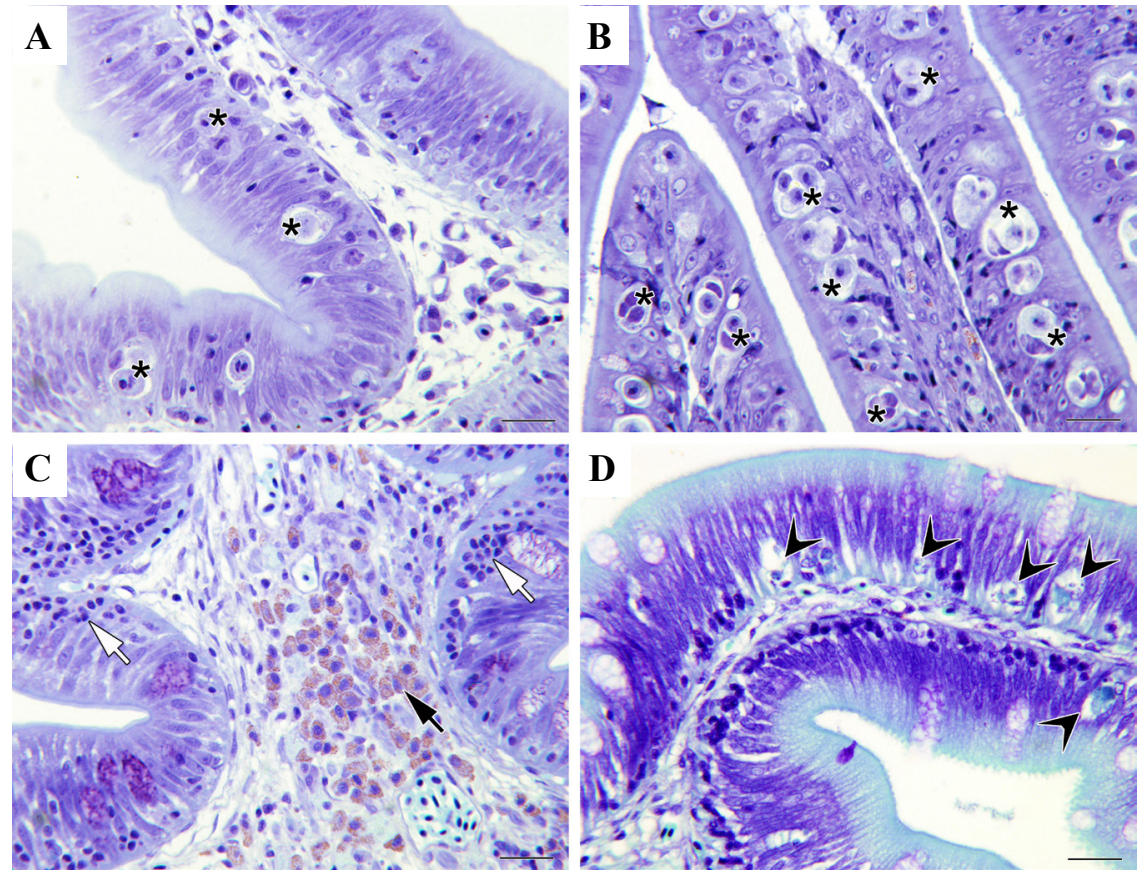

Figure 1. Representative images for T1 and T2 Giemsa stained intestinal sections of naive (A, B) and surviving (C, D) gilthead sea bream. (A) Anterior intestine segment with low infection intensity: Enteromyxum leei stages $\left(^{*}\right)$ consist mainly of primary and secondary cells. (B) Posterior intestine (PI) with high infection intensity: parasite stages $\left(^{*}\right)$ are trophozoites with secondary and tertiary cells. (C, D) Non-infected PI with evident cellular immune response. Aggregates of eosinophilic granular cells in the lamina propria-submucosa (black arrow) and infiltration of lymphocyte-like cells in the epithelium (white arrows) (C) and macrophages with cell debris in the epithelium (arrow heads) (D). Scale bars $=20 \mu \mathrm{m}$.

Since prevalence of infection of T1 NAI fish turned out to be lower than in average infections in our laboratory, a second infection trial (T2) was performed, with additional focus on immune gene expression in tissues, besides humoral immunity. At the second sampling point (61 dpe), prevalence of infection in NAI fish was $75 \%$, whereas only one SUR fish was infected (4.4\%). At the last sampling point (86 dpe), prevalence of infection of NAI increased to $83.3 \%$, whereas it dropped to $0 \%$ in SUR fish (Table 2). The histological examination of T2 intestinal sections of NAI fish at 86 dpe also showed medium infection intensity at the PI (trophozoites with S and $\mathrm{T}$ cells), a low infection intensity at the AI (P cells) and no infection at MI. As in T1, no parasite stages were observed in SUR intestines, and scattered cell debris were found in the epithelium (Figure 1).

Mortalities in T1 rose to $40 \%$ in NAI fish and $20 \%$ in SUR at the last sampling point. Similarly, in T2, mortality was $40 \%$ and $25 \%$ in NAI and SUR fish, respectively. No parasites were found in dead SUR fish, and all NAI dead fish were positive for the parasite. 
Table 2. Prevalence of infection with Enteromyxum leei by PCR and histology (for the last samplings, 175 and 86 days post-exposure (dpe) in T1 and T2, respectively), and fish number of naïve (NAI) and surviving (SUR) gilthead sea bream along trials 1 and 2 (T1 and T2). * Cumulative mortality in SUR fish was due to technical issues. Dead SUR fish were diagnosed post-mortem and found negative for E. leei, whereas dead NAI fish were always positive for the parasite and presented acute disease signs.

\begin{tabular}{|c|c|c|c|c|c|c|c|c|}
\hline & & \multicolumn{4}{|c|}{$\mathrm{T} 1$} & \multicolumn{3}{|c|}{$\mathrm{T} 2$} \\
\hline & Group & 0 & 66 & 105 & 175 & 0 & 61 & 86 \\
\hline Sampled fish & $\begin{array}{l}\text { NAI } \\
\text { SUR }\end{array}$ & $\begin{array}{l}10 \\
20\end{array}$ & $\begin{array}{l}10 \\
20\end{array}$ & $\begin{array}{l}10 \\
20\end{array}$ & $\begin{array}{l}10 \\
16\end{array}$ & $\begin{array}{l}20 \\
24\end{array}$ & $\begin{array}{l}20 \\
23\end{array}$ & $\begin{array}{l}12 \\
18\end{array}$ \\
\hline $\begin{array}{l}\text { Cumulative } \\
\text { mortality (\%) }\end{array}$ & $\begin{array}{l}\text { NAI } \\
\text { SUR }\end{array}$ & $\begin{array}{l}0 \\
0\end{array}$ & $\begin{array}{l}0 \\
0\end{array}$ & $\begin{array}{c}15 \\
0\end{array}$ & $\begin{array}{l}40 \\
20^{*}\end{array}$ & $\begin{array}{l}0 \\
0\end{array}$ & $\begin{array}{c}0 \\
4.2^{*}\end{array}$ & $\begin{array}{l}40 \\
25^{*}\end{array}$ \\
\hline $\begin{array}{l}\text { Prevalence of } \\
\text { infection (\%) }\end{array}$ & $\begin{array}{l}\text { NAI } \\
\text { SUR }\end{array}$ & $\begin{array}{l}0 \\
5\end{array}$ & $\begin{array}{c}0 \\
15\end{array}$ & $\begin{array}{c}40 \\
0\end{array}$ & $\begin{array}{c}20 \\
0\end{array}$ & $\begin{array}{l}0 \\
0\end{array}$ & $\begin{array}{l}75 \\
4.4\end{array}$ & $\begin{array}{c}83.3 \\
0\end{array}$ \\
\hline
\end{tabular}

\subsubsection{Total serum IgM and IgT}

In T1, SUR IgM was significantly higher than NAI IgM before exposure (0 dpe). Serum IgM of NAI fish was significantly higher at 66 dpe and 105 dpe than before exposure to E. leei, whereas SUR sera IgM increased progressively and became significantly higher than at the beginning of the experiment from 105 dpe onwards (Figure 2A). In T2, no significant differences were found between circulating IgM of NAI and SUR groups at any sampling point. NAI IgM was significantly higher at 86 dpe when compared to 0 dpe. In SUR fish, IgM was significantly higher at 86 dpe than in the previous time points (Figure 2B).

No significant differences in total serum IgT were found between NAI and SUR fish at any time point, in any trial. When analysing the IgT serum values within each fish group, only a significant change was detected in T1 in SUR fish (Figure 2C), whose serum IgT dropped at 105 dpe significantly. In T2, no significant changes of circulating IgT levels were detected in any group (Figure 2D). 

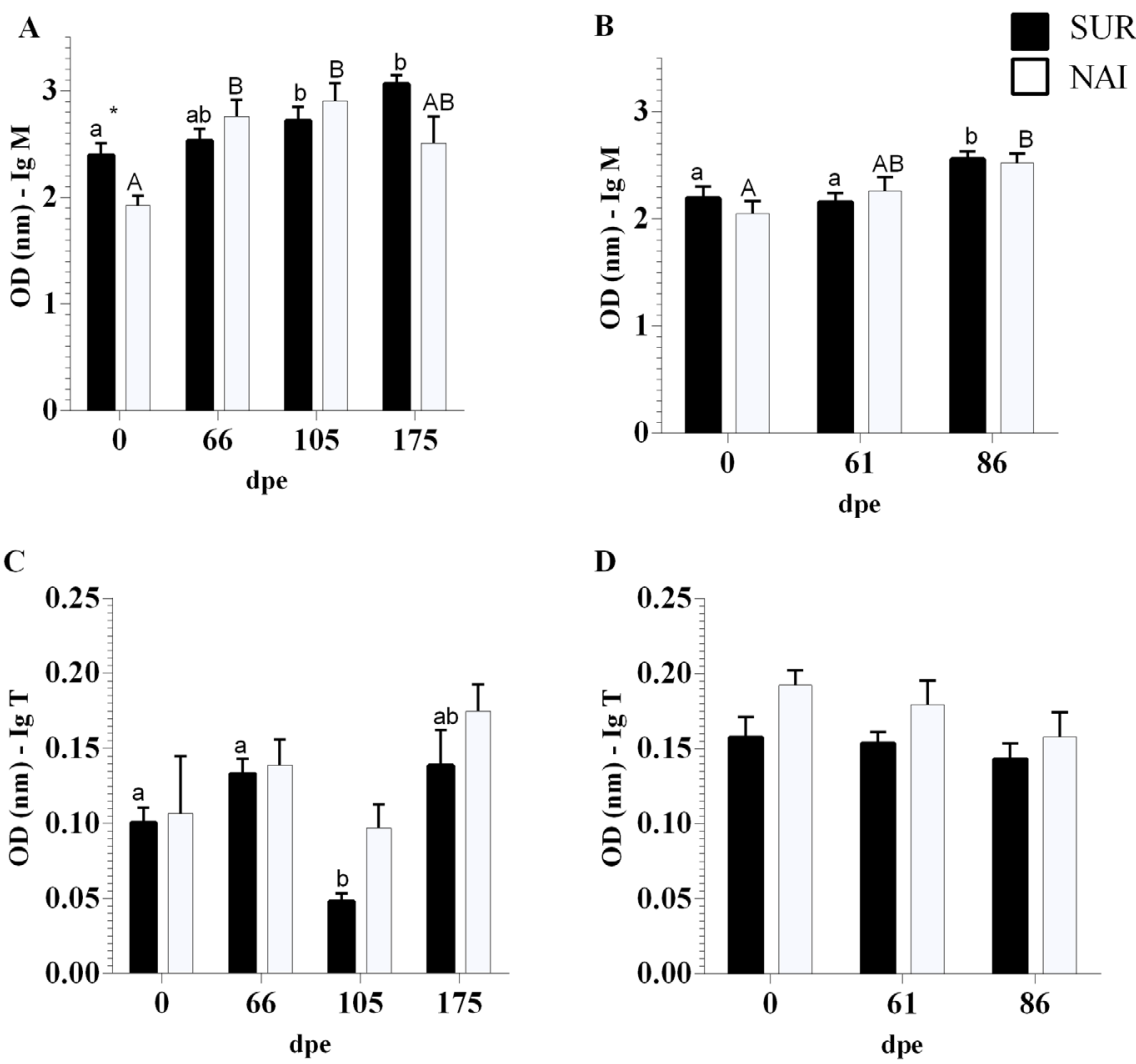

Figure 2. Total serum IgM (A, B) and IgT (C, D) (mean + SEM) of naïve (NAI) and surviving (SUR) gilthead sea bream after exposure to Enteromyxum leei in T1 (A, C) and T2 (B, D) by ELISA. Different lower case (SUR) or upper case (NAI) letters indicate statistically significant differences $(p<0.05)$ within each experimental group along samplings. Asterisks indicate statistically significant differences $(p<0.05)$ between experimental groups at the same time point. dpe = days post exposure.

\subsubsection{Total serum IgM and IgT}

In T1, the percentage of SUR sera with specific IgM remained high throughout all sampling points (65-75\%, Table 3) and there were no significant differences in the mean intensity of specific immunodetection among SUR sera along the trial (Figure 3A). Among all the probed SUR sera that had IgM against E. leei (72.37\%), 69.74\% were non-infected fish and only $2.63 \%$ were infected (Table 3, pie chart). All immunoreactive SUR sera labelled P cells and most of them also S cells and spore valves throughout the trial (Figure 3C). The intensity of parasite immunodetection of SUR sera was significantly higher than that of NAI except at 175 dpe, when NAI intensity reached SUR values (Figure 3A). than that of NAI except at 175 dpe, when NAI intensity reached SUR values (Figure 3A). 

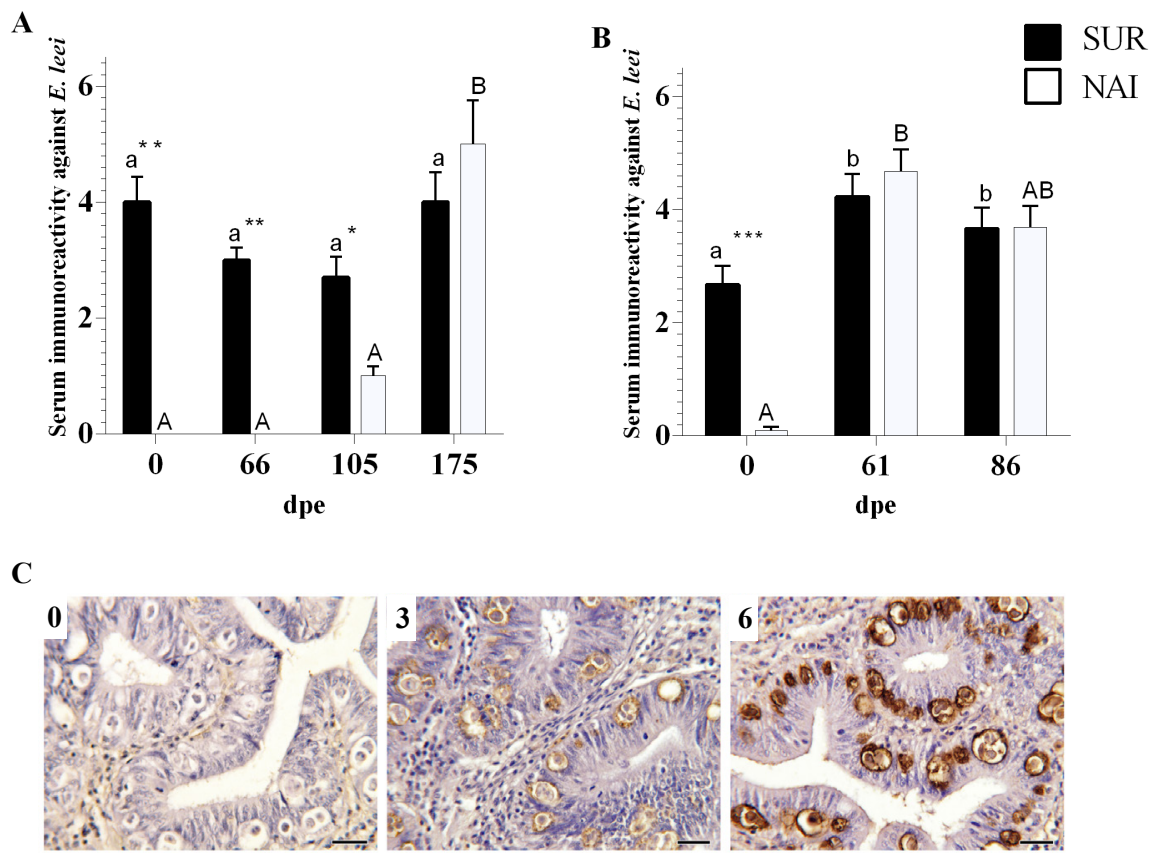

Figure 3. Specific serum immunoreactivity (mean + SEM) against Enteromyxum leei of naïve (NAI) and surviving (SUR) gilthead sea bream in T1 (A) and T2 (B). Intensity of immunoreactivity to the parasite was observed by immunohistochemistry (scaling example is shown in $\mathrm{C}$ for none $=0$, medium $=3$ and maximum =6). Different lower case (SUR) or upper case (NAI) letters indicate statistically significant differences $(p<$ 0.05 ) within each experimental group along samplings. Asterisks indicate statistically significant differences between experimental groups at the same time point $\left({ }^{*} p<0.05,{ }^{* *} p<0.001,{ }^{* * *} p<0.0001\right)$. dpe $=$ days post exposure. Scale bars $=20 \mu \mathrm{m}$.

No specific IgM against the parasite was detected in NAI fish until 105 dpe. At this time point, only $20 \%$ of NAI sera immunoreacted against E. leei with low intensity (Table 3 and Figure 3A). A significant increase of the mean intensity of specific immunodetection was found in $60 \%$ of the NAI sera at 175 dpe. Only $20 \%$ of all analysed NAI sera throughout the trial had specific IgM against the parasite, of which $12.5 \%$ were non-infected fish and $7.5 \%$ were infected (Table 3, pie chart). Immunoreactive sera of 105 dpe NAI fish consistently labelled P and S cells of the parasite stages and spore valves only inconsistently, whereas some 175 dpe NAI sera labelled P cells, $\mathrm{S}$ cells, spore valves and spore accompanying cells consistently (Figure 3A, C). 
Table 3. Naïve (NAI) and surviving (SUR) gilthead sea bream exposed to Enteromyxum leei in trial 1 and 2 (T1 and T2). For each sampling, percentage of fish with specific IgM against the parasite (anti-E. leei+) are given. Within anti-E. leei+ fish, percentages of non-parasitized (anti-E. leei+/non-par) and parasitized (anti-E. leei+/par)fish are indicated. Pie charts show the percentages of total analysed sera in each trial for three fish categories: anti-E. leei+/non-par (blue); IgM anti-E. leei+/ par (red); the remaining, are fish without specific IgM against the parasite (No IgM anti-E.leei ) (green). dpe = days post exposure.

\begin{tabular}{l|c|c|c|c|c|c|c|c}
\multicolumn{1}{c|}{} & \multicolumn{9}{c}{ T1 } & \multicolumn{3}{c}{ T2 } \\
\cline { 3 - 10 } & Group & 0 & 66 & 105 & 175 & 0 & 61 & 86 \\
\hline anti-E. leei+ & NAI & 0 & 0 & 20 & 60 & 15 & 100 & 100 \\
(\%) & SUR & 65 & 75 & 75 & 75 & 83.3 & 91.3 & 83.3 \\
\hline anti-E. leei+/ & NAI & 0 & 0 & 10 & 40 & 15 & 25 & 16.7 \\
non-par (\%) & SUR & 65 & 65 & 75 & 75 & 83.3 & 87 & 83.3 \\
\hline anti-E. leei+/ & NAI & 0 & 0 & 10 & 20 & 0 & 75 & 83.3 \\
par (\%) & SUR & 0 & 10 & 0 & 0 & 0 & 4.3 & 0
\end{tabular}

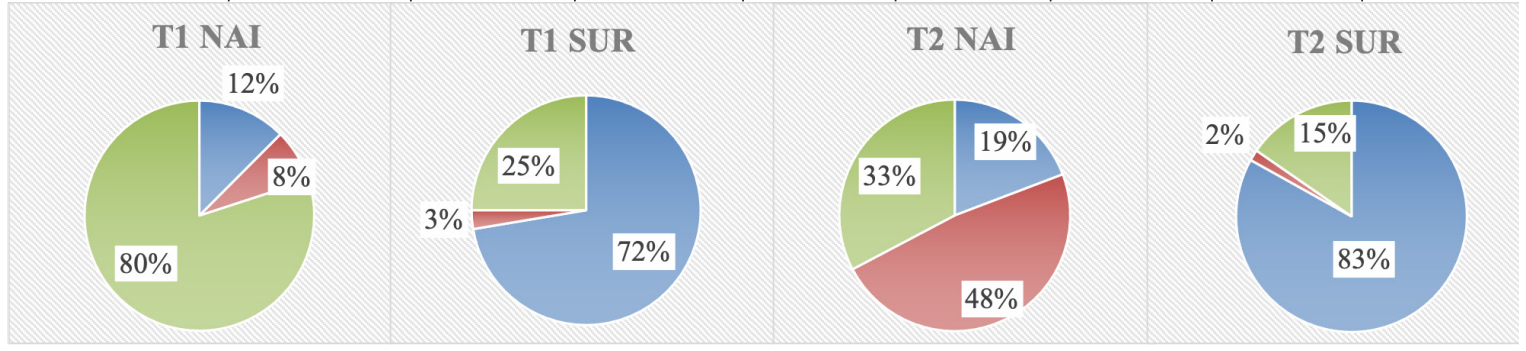

IgM anti-E. leei+/par

IgM anti-E. leei+/non-par

No IgM anti-E. leei

In T2, specific parasite immunodetection by SUR ser a was statistically higher than that of NAI sera only at 0 dpe, with $83.3 \%$ of SUR having specific IgM against the parasite. A significantly higher intensity of specific immunodetection was detected with 61 dpe and 86 dpe SUR sera, when compared to 0 dpe serum. The percentage of SUR sera with specific IgM also remained high in T2, being $91.3 \%$ at $61 \mathrm{dpe}$, and $83.3 \%$ at 86 dpe (Table 3 and Figure 3B). All immunoreactive SUR sera labelled P cells and most of them also $S$ cells and spore valves throughout the trial. Only one SUR fish, which had specific anti-E. leei IgM, was PCR positive for E. leei at 61 dpe (Tables 2 and 3). A significant increase in the intensity of specific immunodetection was found in NAI sera at $61 \mathrm{dpe}$, compared to 0 dpe NAI sera. All NAI sera at 61 and 86 dpe had specific IgM against the parasite, though, 75\% and 83,3\% were infected fish, respectively (Table 3). At these time points, NAI immunoreactive sera labelled consistently $\mathrm{P}$ and $\mathrm{S}$ cells and spore valves only inconsistently (Figure 3B, C). Interestingly, 15\% of the NAI sera immunoreacted against the parasite, though with low intensity, before exposure (0 dpe).

In both trials, contingency analysis demonstrated that there was a significant relationship between previous exposure to the parasite (SUR/NAI variable) and production of specific IgM (anti-E. leeit/anti-E. leei-variable) $(p<0.001)$. There was also a significant relationship between the production of specific IgM (anti-E. leei+/anti-E. leei-variable) and infection status (parasitized/non-parasitized variable) $(p<0.001)$. 


\subsubsection{Total serum peroxidases (PO)}

Total serum PO at T1 were significantly higher in NAI fish than in SUR fish at the first three samplings and dropped at the last sampling to SUR values, which remained lower and constant (Figure 4A).

At T2, no significant differences were found between NAI and SUR groups at any sampling point. SUR values showed a progressive and significant decrease in each sampling point, though NAI PO had no significant variations along the trial (Figure 4B).
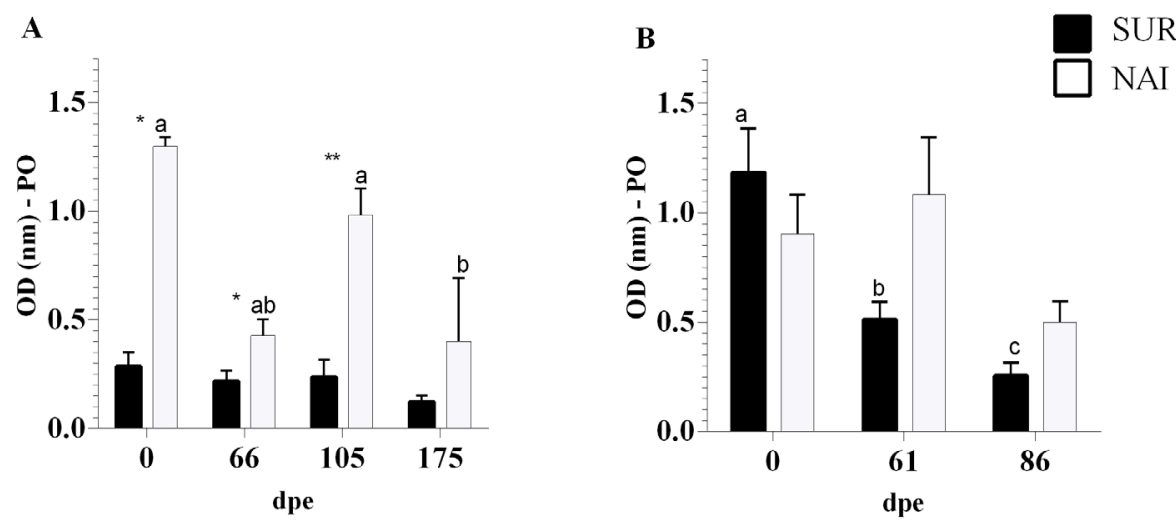

Figure 4. Total serum peroxidases (mean + SEM) of naïve (NAI) and surviving (SUR) gilthead sea bream after exposure to Enteromyxum leei in T1 (A) and T2 (B). Different letters indicate statistically significant differences within each group along samplings. Asterisks indicate statistically significant differences $\left(^{*} p<0.05\right.$; ${ }^{* *} p<$ 0.001 ) between experimental groups. dpe = days post exposure.

\subsubsection{PCR Array: T2}

The expression of 21 immune-related genes was analysed in HK, AI and PI upon infection with E. leei in NAI and SUR fish from T2. Markers of immune response expected to be affected by E. leei infection, such as cytokines, complement, lectins, growth factors, stress markers, antiproteases, cytotoxic enzymes, antigen presentation and mucins were included in this study. The PCR-array also included some markers of adaptive immune response, such as immunoglobulins and a pan

T cell maker. The individual expression of 21 analysed genes relative to $\beta$-actin expression is shown in Supplementary Table 2, and the ratio SUR/NAI of their mean expression in Figure 5.

E. leei re-exposure induced a significantly higher expression of soluble IgM, soluble $I g T$ and membrane $I g T$ in AI of SUR fish when compared to NAI animals. However, at the HK and PI of SUR, IgT was less expressed. SUR fish also showed higher expression of $i l 10$ and lower of $i l 1 \beta$, at the AI and a higher expression of the 
cytotoxic enzyme (gzma) in the AI and PI. Both, complement related genes, $\mathrm{c} 3$ and $f c l$, were higher in HK and PI of SUR fish, and zap70 (marker of T lymphocytes) was higher in HK. Antigen presentation related genes showed no significant differences between groups. The stress marker $h s p 90 \alpha$ was lower in the PI of SUR. The expression of the two included antiproteases had opposite patterns, appearing lcp1 down-regulated and $\alpha 2 m$ up-regulated in SUR animals. The expression of imuc was lower at the AI of SUR fish (Figure 5).

\begin{tabular}{|c|c|c|c|c|}
\hline \multirow{6}{*}{$\begin{array}{c}s \operatorname{Ig} M \\
\operatorname{sig} T \\
m \operatorname{Ig} T \\
m \operatorname{Ig} M \\
\operatorname{Ig} D\end{array}$} & HK & PI & AI & \multirow{6}{*}{ Immunoglobulins } \\
\hline & 0.02 & -0.25 & 1.04 & \\
\hline & -1.92 & -2.97 & 0.88 & \\
\hline & -0.68 & 0.1 & 0.66 & \\
\hline & 0.26 & -0.48 & -0.28 & \\
\hline & -0.01 & -0.68 & -0.56 & \\
\hline zap70 & 0.72 & 0.17 & -0.01 & Pan T cell marker \\
\hline gzma & -0.94 & 0.62 & 1.62 & Cytotoxic enzyme \\
\hline \multirow{2}{*}{$\begin{array}{c}i l 17 a / f \\
i l 1 b\end{array}$} & -1.77 & -0.26 & -0.08 & \multirow[t]{5}{*}{ Cytokines } \\
\hline & -0.35 & -0.16 & -1.18 & \\
\hline il6 & 0.31 & -0.84 & 0.53 & \\
\hline$i l 10$ & -0.22 & 0.29 & 0.71 & \\
\hline ifng & 0.03 & -0.33 & 0.38 & \\
\hline \multirow{2}{*}{$\begin{array}{c}\text { mhcIIb } \\
2 m\end{array}$} & -0.2 & 0.27 & 0.16 & \multirow[t]{2}{*}{ Antigen presentation } \\
\hline & 0.15 & 0.26 & 0.2 & \\
\hline$c 3$ & 1.95 & 0.97 & -0.21 & Complement \\
\hline$f c l$ & 2.05 & 1.13 & -1.12 & \multirow[t]{2}{*}{ Lectins } \\
\hline$m r c 1$ & -0.15 & -0.03 & -0.11 & \\
\hline igf I & -0.61 & 0.29 & -0.76 & Growth factor \\
\hline hsp90a & 0.51 & -2.02 & -0.42 & Stress marker \\
\hline lcp I & -5.35 & -1.84 & -2.18 & \multirow[t]{2}{*}{ Antiproteases } \\
\hline $2 m$ & 0.85 & 1.41 & 0.09 & \\
\hline ітис & & 0.13 & -2.71 & Mucin \\
\hline
\end{tabular}

Figure 5. Heatmap depicting the differential expression of 22-immune related genes in trial 2, categorized by their functional categories, in head kidney (HK), posterior (PI) and anterior (AI) intestine, at 86 days postexposure to Enteromyxum leei (final sampling point). The log2 fold change (Log2FC) of the ratio between the mean relative expression of the selected surviving (SUR, $n=8$ ) and naïve (NAI, $n=8$ ) gilthead sea bream is shown for each gene. The colour scale was only applied to the significantly differentially expressed genes (ANOVA, $p<0.05$ ). Bold numbers in red indicate significantly higher expressed genes in SUR animals. Bold numbers in green indicate significantly lower expressed genes in SUR animals. For clarity, non-differentially expressed genes appear in white.

\subsubsection{Cluster analysis}

To have an overview of all the results, K-means clustering was performed gathering all available data of T2 samples (Figure 6A). All individual data used in this analysis can be found in Supplementary Table 2. Due to the high variability and the heterogeneous nature of the different data sets, dimension reduction was 
not very efficient, with the first two principal components (PC) explaining only $28.9 \%$ of the total variability (PC1 17.42\% and PC2 11.7\%). However, cluster analysis clearly separated SUR from NAI fish. One NAI fish (NAI_2) clustered separated from the other two groups, creating a third cluster. Interestingly, this particular individual was the one showing the highest level of infection in both, the nonlethal sampling at $61 \mathrm{dpe}$ and in the histological scoring of the PI at $86 \mathrm{dpe}$. The variables that had more weight driving the separation of the clusters were the expression of il10 in AI and the presence of specific antibodies at 0 dpe in SUR sera (Figure 6B). The high expression of ifny sIgM and mIgM in PI; sIg T in HK; and the high intensity of infection, drove NAI_2 to cluster separately. This overall data analysis demonstrated the differential profile of NAI and SUR fish upon parasite infection and highlighted immunoglobulin expression, both at systemic and local levels, as important markers of the response of the fish to the disease.
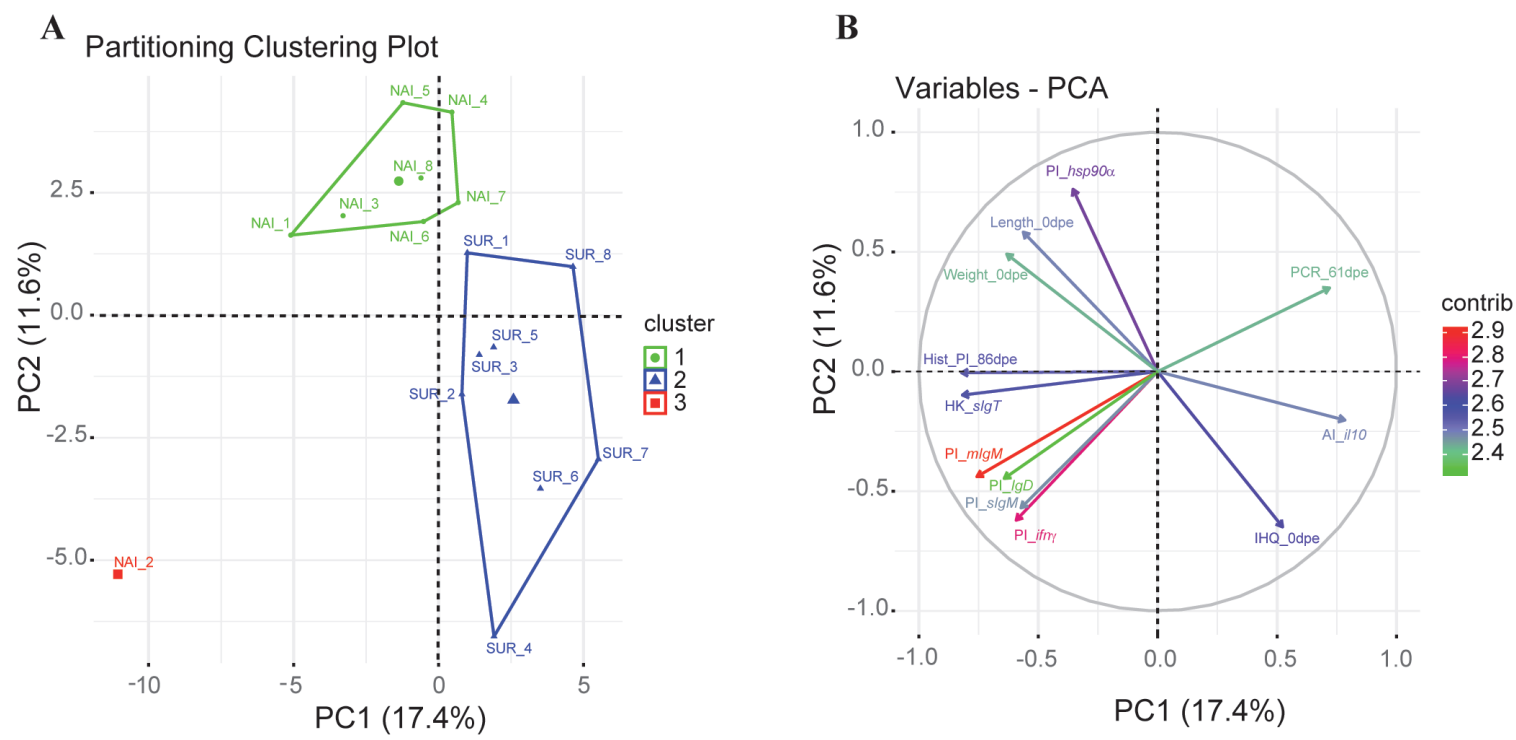

Figure 6. K-means cluster analysis using all variables available in all the sampling points. Surviving (SUR, $n$ $=8$ ) and naïve (NAI, $\mathrm{n}=8$ ) gilthead sea bream to the parasite Enteromyxum lee, whose gene expression was analysed in T2, were used to construct the plots. (A) Cluster plot showing the first two principal components of the k-means analysis with $k=3$. Cluster 1 (green) is entirely constituted by NAI fish, whereas all SUR fish group in cluster 2. Cluster 3 is constituted by a single individual from the NAI group that failed to group in any of the other two clusters. (B) Contribution plot for the 12 variables with more weight in the clustering. The colour scale represents the percentage of contribution for each variable.

\subsection{DISCUSSION}

We have demonstrated that gilthead sea bream that survived a previous infection with the myxozoan parasite E. leei are resistant to enteromyxosis upon rechallenge in two different trials, with different infective pressure. Re-exposed fish (SUR) exhibited higher levels of circulating IgM (total and specific against $E$. leei) and differential immune gene expression, when compared to naïve fish (NAI) 
exposed for the first time to the parasite. At the beginning of both trials, a higher percentage of SUR fish possessed specific anti-E. leei IgM, and these antibodies immunoreacted with stronger intensity against the parasite, which apparently helped them to cope with the parasite during the re-exposure. Furthermore, SUR fish had a higher expression of Igs in AI, higher local cytotoxic activity, and higher local and systemic activation of molecules related to the lectin pathway of complement. The higher expression of the regulatory cytokine il10 and the lower expression of the acute pro-inflammatory cytokine ill $\beta$ in AI, together with the histopathological observations, point towards an anti-inflammatory or resolution phenotype in the intestines of SUR fish.

Parasite transmission and establishment in recipient fish was slower in T1 than in T2, evidenced by the longer duration of the experiment (175 vs 86 days), and the lower prevalence of infection in T1. This difference was probably due to differences in the infective pressure on recipient fish, mainly due to the different water temperature. $\mathrm{T} 1$ started in winter when water was kept at $18^{\circ} \mathrm{C}$, whereas T2 started in summer, with an initial natural water temperature of $22.8^{\circ} \mathrm{C}$. Also, mean water temperature was lower in T1, being $19.6^{\circ} \mathrm{C}$ vs $24.3^{\circ} \mathrm{C}$ in T2 (Table 1). As previously shown, water temperature is critical for E. leei infections (Yanagida et al., 2006).

Regardless of these differences, in both trials, total circulating IgM increased over time in both experimental groups. The high level of total IgM of SUR fish in T1 before challenge ( 0 dpe) might be related to the greater age and size of this fish, but the higher levels of specific IgM of SUR fish in both trials (65\% in T1, 83.3\% in T2) point to a primed basal status after a first infection. In fact, global cluster analysis highlighted the importance of the initial high anti-E. leei specific IgM in SUR fish for their differential response when compared to NAI. In addition, immunoreactivity of the anti-E. leei specific IgM in all SUR sera was significantly stronger than in NAI sera, pointing to a greater affinity of these Igs for the parasite's antigens, at least initially, in both trials. The higher percentage of fish with specific anti-E. leei IgM and the higher affinity of these antibodies likely contributed to limit parasite spreading in SUR fish.

An early immune response after re-exposure is indicative of an acquired immune response (anamnestic response), in which a specific antigen activates its counterspecific B cell into differentiation and clonal expansion for early specific Ig production (Burnet, 1976). In the current study, anti-E. leei specific IgM in the SUR group remained high up to 16 months after these fish were first infected by the parasite, though we do not know exactly when parasite clearance occurred. Longterm protection against $E$. leei by B cells could be feasible, as such long-term B 
cell responses have been suggested for some teleost species. Specific antibodies against the pathogenic flagellates Amyloodinium ocellatum, Cryptobia salmositica, Trypanoplasma borreli and Trypanosoma carassii are found after recovery from disease outbreaks and experimental exposure and immunization trials in several teleost species (Woo \& Ardelli, 2014). Rainbow trout re-exposed after 1 year to $T$. bryosalmonae responded with significantly increased circulating $\operatorname{IgM}^{+} \mathrm{B}$ cells and up-regulated secretory IgM expression in the posterior kidney, compared to unexposed and naïve-exposed fish already at 10 dpe (Bailey et al., 2017). Similarly, channel catfish re-challenged 9 weeks after first infection with the ciliate parasite Ichthyophthirius multifiliis had higher specific antibody titres from 5 to 22 weeks after re-exposure (Findly et al., 2013). No data on the starting IgM/antibody status of the re-exposed fish at 0 dpe is available for the latter examples, but those fish maintained specific antibody secreting cells and detectable specific antibody titres in serum for approximately 1 year. Goldfish that recovered from T. carassii infection produced protective specific IgM with high in vitro lytic activity even before rechallenge (Katzenback et al., 2013). Concerning IgM affinity, 10-fold increases were detected in rainbow trout after stimulation with diverse immunogens (Costa et al., 2012; Ye et al., 2010, 2011). In resistant turbot to E. scophthalmi, low levels of specific IgM were detected long after re-exposure (three years later) (Sitjà-Bobadilla et al., 2007a, 2007b). In the current study, gilthead sea bream showed long-lasting and protective anti-E. leei seroprevalence, which would imply the existence of persistent antigen-specific antibody-secreting plasma cells besides memory B cells.

In SUR fish, the secondary exposure to the parasite apparently triggered the clonal selection and expansion of B cells expressing protective IgM with specificity for $E$. leei antigens. Thus, in both trials most of the SUR fish remained uninfected and the few SUR fish diagnosed as positive for E. leei at intermediate time points, scored negative at the end of the experiment, evidencing their acquired protection. By contrast, NAI fish had a faster systemic IgM response, which however, did not confer initial protection against the parasite, due to the lack of specific anti-E. leei IgM in the sera of NAI fish until advanced time points, when the infection was already established. In regard to myxozoan infections, in rainbow trout re-exposed to $T$. bryosalmonae, the cellular adaptive response (increase in $\operatorname{IgM}^{+}$circulating $B$ cells) resulted in lower prevalence and intensity of infection (Bailey et al., 2017). In Atlantic salmon re-exposed to $K$. thyrsites the cell-mediated immune response by means of macrophages/dendritic cells, cytotoxic T cells, and B cells, resulted in lower parasite prevalence and infection intensity (Braden et al., 2018). Those leukocyte populations probably also have a pivotal role in the adaptive immune response of the current SUR fish, but further studies will be needed to decipher their implication. 
Concerning NAI fish, total serum IgM increased initially faster than in SUR fish, and NAI presented significantly higher levels of total serum IgM already at 66 dpe (T1) and 86 dpe (T2), compared to 0 dpe. Focusing on naïve gilthead sea bream, significantly higher IgM was previously reported at protein level in recipient fish sera (Piazzon et al., 2016a) and at transcriptional level in the PI (Estensoro et al., 2012a) after 133 days of effluent exposure to the parasite. One of these studies also detected up-regulation of soluble and membrane IgM only at the PI 64 days after anal intubation with the parasite, which provokes a faster progression of the infection (Piazzon et al., 2016a). With both experimental transmission methods a concomitant significant increase of $\operatorname{IgM}^{+}$B cells occurred in the PI and HK (Estensoro et al., 2012a, 2013b). Thus, inflammation during enteromyxosis engaged local and systemic IgM response in gilthead sea bream, supporting the current higher early levels of circulating IgM in NAI fish. Interestingly, during the inflammatory response elicited in Chinook salmon by $C$. shasta, a susceptible fish strain developed a premature response including early recruitment of $\mathrm{Ig}^{+}$cells to the intestine, unable to arrest parasite proliferation, while resistant salmon recruited Ig+ cells to the site of infection later (Bjork et al., 2014). Such a premature or hyperactive Ig response in susceptible fish resembles the early response in the present NAI gilthead sea bream.

Most SUR fish in both trials (69.7\% in T1; 83.1\% in T2) produced specific anti-E. leei IgM and were not infected upon re-exposure, probably because they were preexposed to the immunogen. By contrast, NAI fish with specific IgM were mostly infected. At 61 dpe, a specific/acquired IgM response seems to be already engaged during the intense exposure to the immunogen (T2), which only happened from 105 dpe onwards under the lower infective pressure of T1. However, specific anti-E. leei IgM was also present in non-infected NAI fish (12.5\% in T1; 19.2\% in T2), and even some NAI sera had E. leei-specific IgM immunoreactivity at 0 dpe in T2. Yet, the increase in NAI fish of IgM (total and E. leei-specific) over the course of the infections became evident, correlating with parasite load (T2 > T1). However, the Ig-response in NAI fish was unable to prevent parasite establishment, at least during the period of the trials. Timing and magnitude of the specific immune response against the parasite in NAI fish was probably responsible for its initial failure in parasite clearing during a first exposure, since selection and boost of the $B$ cell clones expressing the protective Igs would occur later. Though detection of specific anti-E. leei IgM has not been reported before, previous studies also found increased local and systemic IgM and IgT, as well as $\operatorname{IgM}^{+}$B cells/plasma cells during enteromyxosis in naïve gilthead sea bream (Estensoro et al., 2012a, 2013a; Piazzon et al., 2016a). These Ig-responses by the host were now shown to shift quite late during parasite invasion from non-specific to specific. 
A high proportion of the non-specific, naturally occurring antibodies is constituted by IgM antibodies and is the basis of combinatorial/acquired immunity early since vertebrate evolution (Marchalonis et al., 2006). Our data suggest the presence and boost of natural IgM with specificity for certain antigens present in E. leei, at least for the 0 dpe immunoreactive IgM found in NAI fish (T2). However, the inability of NAI fish in both trials to generate substantial initial protection even after triggering an Ig-response, could be related to the lower affinity for the parasite of these antibodies. Correlation between natural antibody titres and ability to generate protective and specific primary and secondary antibody responses has been detected for some salmonids and cyprinids (Sinyakov et al., 2002, Stromsheim et al., 1994). Whether such correlations influence the humoral immune response of naïve gilthead sea bream was beyond the scope of the present study, but would deserve detailed investigation. Yet, vaccination trials performed on gilthead sea bream against virus or bacteria have given contradictory results in regard to acquired protection associated to IgM titres (Joosten et al., 1995; Magariños et al., 1994; Valero et al., 2018).

The emergence of specific anti-E. leei IgM with significant immunoreactivity in NAI fish sera only happened after 175 dpe under the low infective pressure of T1, and earlier, at $61 \mathrm{dpe}$, with the higher infective pressure of T2. In both trials, sera of NAI fish apparently immunoreacted with the same parasite structures as SUR sera, namely $\mathrm{P}$ and $\mathrm{S}$ cells, and towards the end of the trials also consistently with spore valves and spore accompanying cells. Thus, $\mathrm{P}$ and $\mathrm{S}$ proliferative stages of E. leei, first to colonize the host tissues early during infection, were the most immunogenic parasite structures. Sporogonic stages, which chronologically develop later in the fish host, were less immunogenic, especially in NAI fish.

While the systemic IgM response seems to play a major part during the development of the acquired immune response against $E$. leei, serum IgT seemed to have a lesser role in this play. Serum IgT in T2 showed a decreasing trend over time, especially in NAI fish, which might reflect depletion after its consumption. In T1, IgT depletion seemed to occur at 105 dpe and recovered later at 175 dpe in both experimental groups. However, serum IgT might only reflect a transition state during $\operatorname{IgT}^{+} \mathrm{B}$ cell recruitment into its main action site, the mucosal compartment where infection is taking place. IgT has been described as an Ig isotype with an important mucosal role similar to the mammalian IgA (Zhang et al., 2010) and plays an important function combating other myxozoans, such as C. shasta in the intestine (Zhang et al., 2010), and T. bryosalmonae in the kidney (Abos et al., 2018). It is tempting to suggest that the transient depletion of serum IgT at 105 dpe in T1 and the decreasing trend in T2 could reflect recruitment of circulating IgT ${ }^{+} \mathrm{B}$ cells towards the local site of infection for SUR and NAI fish, but the study of IgT dynamics in gilthead sea bream during infection would deserve a thorough study. At transcriptional level, 
lower sIgT expression in $\mathrm{HK}$ together with a higher sIgT expression in $\mathrm{AI}$ in SUR, might indicate more intense recruitment of $\mathrm{IgT}^{+} \mathrm{B}$ cells/activated plasma cells into SUR fish intestines, than in NAI intestines. In PI, no increase of sIgT in SUR vs NAI was found, which can be explained by the high expression found in NAI during the first and more intense contact with the parasite at the target site of infection, according to a previous study (Piazzon et al., 2016a). Besides, a local accumulation of IgT+ $\mathrm{B}$ cells at the AI from the previous exposure to E. leei might have occurred. Likewise, aggregates of $\mathrm{IgT}^{+}$cells were found in rainbow trout skin after 3 months of exposure with I. multifiliis (Xu et al., 2013), and in rainbow trout intestine an accumulation of $\operatorname{IgT}$ and $\operatorname{IgT}^{+} \mathrm{B}$ cells were found in the lamina propria three months after C. shasta infection (Zhang et al., 2010). Unfortunately, the available anti-gilthead sea bream IgT antibody does not work in immunohistochemistry, so we were not able to study the levels of specific IgT in NAI and SUR fish.

Among the studied cytokines, only il1 $\beta$ and il10 showed differential expression in AI of SUR animals when compared to NAI. The higher expression of il10 and the lower expression of il1 $\beta$ in SUR animals could indicate a shift to an antiinflammatory profile characteristic of inflammation resolution. The pleiotropic regulatory cytokine IL10 is considered one of the most important antiinflammatory cytokines responsible for limiting and terminating inflammation, in order to prevent damage and help to the formation of long-lived memory cells against future threats. This cytokine has been extensively studied in mammals and fish with no apparent major functional differences (Mosser et al., 2008; Piazzon et al., 2016b). One of its main activities is the inhibition of the expression of proinflammatory cytokines by phagocytes and T lymphocytes, among which, il1 $\beta$ is one of the main affected (Piazzon et al., 2015). In fact, an anti-inflammatory profile 64 days after anal intubation with the parasite has been described in gilthead sea bream intestines with significant up-regulation of il10 (Pérez-Cordón et al., 2014). IL10 also increases the cytotoxic activity of mammalian NK cells (Carson et al., 1995) and stimulates B cell proliferation, maturation and antibody secretion both in mammals and fish (Piazzon et al., 2015). The up-regulation of il10 during long-lasting parasitic infections of carp with $T$. borreli and $T$. carassii actually coincided with the appearance of higher concentrations of specific antibodies against the parasites and the concomitant down-regulation of pro-inflammatory genes (Piazzon et al., 2016b, 2017). In the current study, the higher expression of il10 in AI of SUR fish is also parallel to lower expression of il1 $\beta$, higher expression of immunoglobulins (particularly the soluble forms) and a higher expression of the cytotoxic enzyme gzma. Thus, these results point to a key role of IL10 in the resolution of E. leei infection and the accurate production of a protective memory pool. 
In the current study, we did not detect significant differences in zap70 expression in intestines of SUR and NAI fish. However, SUR fish show higher expression of this T cell marker in HK, probably pointing to a replenishment of T cells in this organ in those animals where the infection was successfully avoided or beaten. However, the significantly higher zap70 SUR/NAI ratio could have also been induced by the previously reported HK depletion of $\mathrm{T}$ cells in naïve fish during intestinal recruitment or by $\mathrm{T}$ cell proliferation induced by the secondary exposure. Zap70 is a commonly used pan T cell marker, in both fish and mammals (Nakanishi et al., 2015; Piazzon et al., 2015). Previous studies revealed its up-regulation in intestines of E. leei infected gilthead sea bream, parallel to a down-regulation in head kidney, due to $\mathrm{T}$ cell migration to the target tissue where they became activated (Piazzon et al., 2018).

In our study, the higher expression of gzma in SUR animals could indicate a higher activation or presence of cytotoxic cells during a secondary exposure helping to avoid parasite establishment. Gzma is one of the cytolytic effector molecules released by cytotoxic cells such as cytotoxic T lymphocytes (CTL) and non-specific cytotoxic cells (NCC) (Evans et al., 1992). Both CTLs and NCCs express many receptors, transcription factors and effector molecules in common (Rau et al., 2002). It is difficult to determine which cell population is involved in the current study, but previous studies seem to indicate that both NCCs (Cuesta et al., 2006b) and CTLs (Piazzon et al., 2018) are involved in E. leei clearance and fish survival. Cytotoxic activity, mainly related to CD8 ${ }^{+}$CTLs, was also linked to successful resolution of infection and protection upon re-exposure in Atlantic salmon infected with the myxozoan parasite $K$. thyrsites (Braden et al., 2018).

Concerning innate immune factors, total serum PO, involved in the oxidative response against pathogens, showed different kinetics in each trial, but all ended in PO depletion. SUR fish in T1 had significantly lower serum PO than NAI and remained stable, whereas in T2 SUR fish had remarkably higher levels than in T1, and showed a faster decrease than NAI. The differences found between SUR and NAI in T1 might be related to the different age or genetic background of these fish, one of the reasons for which T2 was conducted with animals from the same stock and age. The involvement of serum PO in the immune response against $E$. leei has previously been reported only in the context of primary responses in naïve fish (Estensoro et al., 2012b, 2014; Muñoz et al., 2007). Fish serum peroxidases, enclosed in the granules of phagocytic cells, participate in the respiratory burst cascade (Meseguer et al., 1994) and are capable of local and systemic regulation and intervention upon infections (Marcos-López et al., 2017; Steinhagen \& Hespe, 1997), dietary intervention (Cerezuela et al., 2016; Hossain et al., 2018; Salinas et al., 2008) and exposure to waterborne toxics (Guardiola et al., 2013; Hossain et al., 2018). Peroxidase bearing granulocytes in gilthead sea bream are neutrophils and 
acidophils (Havixbeck \& Barreda, 2015). The significant contribution of these cells to the resolution phase of inflammatory responses in teleosts (Havixbeck et al., 2016) and specifically in gilthead sea bream (Gómez-Abellán et al., 2015), has been pointed out, and their involvement in the immune response found in SUR fish might be related.

Other innate immune effectors were differentially expressed in SUR fish during the secondary immune response to the parasite. This was the case of $\alpha 2 \mathrm{~m}$, whose expression was higher in SUR animals upon re-exposure to E. leei. This pan-protease inhibitor, involved in the clearance of virtually any host or foreign proteinase via endocytosis (Borth, 1992), was also up-regulated at gene and protein expression levels in other myxozoan infections in different fish species (Muñoz et al., 2007; Sitjà-Bobadilla et al., 2006, 2008b; Sitjà-Bobadilla \& Palenzuela, 2012). In all these cases, this up-regulation was measured during the peak of parasitic infections in naïve fish and the assumed role in these particular scenarios was the clearance of parasite proteinases to counteract tissue invasion. The biological importance of $\alpha 2 \mathrm{M}$ during parasitic infections has been demonstrated from invertebrates to mammals, and its additional role in the maintenance of tissue homeostasis during the resolution of the inflammatory response has been described (De Souza et al., 2008). LCP1 is another protease inhibitor that belongs to the group of Stefins (members of the cystatin superfamily of cysteine proteinase inhibitors) (Turk et al., 2019). The expression of $l c p 1$ in gilthead sea bream was also up-regulated in previous E. leei infections and dietary intervention studies (Calduch-Giner et al., 2012; Davey et al., 2011).

Molecules related to the complement system were also modulated in SUR fish. The genes $c 3$ and $f c l$ had a higher expression in SUR fish during the secondary response to the parasite at local and systemic levels. In agreement with this, serum complement activity by the alternative pathway was also decreased in gilthead sea bream during the primary acute response to E. leei (Cuesta et al., 2006c; Estensoro et al., 2012b) and the expression of complement components was down-regulated in PI and HK of E. leei-infected gilthead sea bream (Davey et al., 2011), which was interpreted as a parasitosis-associated immunodepression. Regulation of the expression of $f c l$ in naïve gilthead sea bream intestines was also found in response to enteromyxosis (down-regulation) (Calduch-Giner et al., 2012) and to dietary intervention (up-regulation) (Pérez-Sánchez et al., 2015). The current re-exposed SUR fish showed no signs of such immunodepression by the parasite, and the expression of complement genes appeared to be re-established or even improved, compared to NAI fish. Complement, specifically C3 and its receptors, play an important role in antigen uptake, internalization, presentation, and generation of an antibody response in all vertebrates, thereby interconnecting innate and acquired immune responses (Sunyer et al., 2003). F-type lectins, such as $f c l$, are 
pattern recognition receptors found in the serum of several fish species, including gilthead sea bream, and play an active role in PAMP recognition, opsonisation, phagocytosis, and complement activation (Álvarez-Pellitero, 2011).

A lower expression of $i-m u c$ was found in the AI of SUR fish compared to NAI. Mucin expression in the gastrointestinal tract of gilthead sea bream has tissuespecific distribution. The intestinal mucin (i-muc) is constitutively highly expressed at the PI and was down-regulated in this intestinal segment due to primary $E$. leei infection or to dietary intervention (Pérez-Sánchez et al., 2013). The modified mucin expression could imply changes in intestinal susceptibility to further biological or chemical offenders, as mucins are part of the mucosal surface of the gastrointestinal tract, that modulate many biological processes like cell adhesion, molecular trafficking and receptor activation, and are key players in host-pathogen interactions (Álvarez-Pellitero, 2011).

The expression of $h s p 90 \alpha$ was lower in the PI of SUR fish than in NAI. Molecular chaperones, including HSPs, are life-essential peptides that stabilize unfolded proteins and their expression is highly inducible under cellular stress in higher vertebrates (Stetler et al., 2010) and fish (Deane \& Woo, 2011). In previous studies, several HSPs were consistently up-regulated in primary E. leei-infected gilthead sea bream intestines (Calduch-Giner et al., 2012). The current results further highlight the different phenotypes of the two experimental groups. Namely, NAI fish develop an intense inflammatory response during their first exposure to the parasite, induced by the intestinal infection, and engage a late production of circulating specific antibodies and activation of the parasite-combatting machinery at the target site. SUR fish, by contrast, are characterised by the reestablishment of homeostasis and stress/inflammation resolution.

In conclusion, gilthead sea bream re-exposed to E. leei mount an early and effective adaptive humoral immune response, involving higher circulating IgM, which is more specific against the parasite, than in gilthead sea bream exposed to the parasite for the first time. Fish resistant to the parasite with high titres of specific IgM (SUR) do not exhibit the usual enteritis-associated signs, which naïve fish develop during enteromyxosis (pro-inflammatory gene expression profile, hypertrophy of intestinal submucosa), but instead have a phenotype distinctive of inflammation resolution. SUR Ig-response was supported by other involved immune mechanisms like cell cytotoxicity and complement. The current results shed some light on the limited knowledge of adaptive immune responses against myxozoan parasites in sparids. Future research efforts will have to be made in order elucidate which cell effectors are involved in the acquired resistance of gilthead sea bream to E. leei. 


\section{ACKNOWLEDGEMENTS \& FUNDING}

Primer sequences and access to the gilthead sea bream transcriptomic database were kindly provided by Prof. J. Pérez-Sánchez of the IATS- Nutrigenomics group. The authors thank J. Montfort and L. Rodríguez for histological processing and I. Vicente for fish maintenance and technical assistance during samplings.

This study was supported by EU H2020 program and by the Spanish Ministry of Economy and Competitiveness through ParaFishControl (634429) and AGL-201348560-R research projects, respectively. This publication reflects the views only of the authors, and the European Commission cannot be held responsible for any use which may be made of the information contained therein. MCP was contracted under CSIC PIE project no. 201740E013 and IE was recipient of APOSTD/2016/037 grant by the "Generalitat Valenciana". 


\section{Bibliography}


Abos B., Estensoro I., Perdiguero P., Faber M., Hu Y. F., Rosales P. D., Granja A. G., Secombes C. J., Holland J. W., Tafalla C. (2018) Dysregulation of B cell activity during proliferative kidney disease in rainbow trout. Front Immunol. 9:1203.

Álvarez-Pellitero P. (2011) Mucosal intestinal immunity and response to parasite infections in ectothermic vertebrates, in: Álvarez-Pellitero P. (Ed.) Nova Science Publishers, Inc. New York, USA. pp. 1-108.

Álvarez-Pellitero P. (2008) Fish immunity and parasite infections: From innate immunity to immunoprophylactic prospects. Vet Immunol Immunopathol. 126:171-198.

Athanassopoulou F., Prapas T., Rodger H. (1999) Diseases of Puntazzo puntazzo Cuvier in marine aquaculture systems in Greece. J Fish Dis. 22:215-218.

Bailey C., Segner H., Wahli T. (2017) What goes around comes around: An investigation of resistance to proliferative kidney disease in rainbow trout Oncorhynchus mykiss (Walbaum) following experimental re-exposure. J Fish Dis. 40:1599-1612.

Bartholomew J. L. (1998) Host resistance to infection by the myxosporean parasite Ceratomyxa shasta: A review. J Aquat Anim Health. 10:112-120.

Bjork S. J., Zhang Y. A., Hurst C. N., Alonso-Naveiro M. E., Alexander J. D., Sunyer J. O., Bartholomew J. L. (2014) Defenses of susceptible and resistant Chinook salmon (Onchorhynchus tshawytscha) against the myxozoan parasite Ceratomyxa shasta. Fish Shellfish Immunol. 37:87-95.

Borth W. (1992) Alpha 2-macroglobulin, a multifunctional binding protein with targeting characteristics. FASEB J. 6:3345-3353.

Braden L. M., Rasmussen K. J., Purcell S. L., Ellis L., Mahony A., Cho S., Whyte S. K., Jones S. R. M, Fast M. D. (2018) Acquired protective immunity in Atlantic salmon Salmo salar against the myxozoan Kudoa thyrsites involves induction of MHII beta (+) CD83 (+) antigen-presenting cells. Infect Immun. 86:e00556-17.

Burnet F. M. (1976) A modification of Jerne's theory of antibody production using the concept of clonal selection. CA Cancer J Clin. 26:119-121.

Calduch-Giner J. A., Sitjà-Bobadilla A., Davey G. C., Cairns M. T., Kaushik S., Pérez-Sánchez J. (2012) Dietary vegetable oils do not alter the intestine transcriptome of gilthead sea bream (Sparus aurata), but modulate the transcriptomic response to infection with Enteromyxum leei. BMC Genomics. 13:470.

Canning E. U., Okamura B. (2004) Biodiversity and evolution of the myxozoa. Adv Parasitol. 56:43-131.

Carson W. E., Lindemann M. J., Baiocchi R., Linett M., Tan J. C., Chou C. C., Narula S., Caligiuri M. A. (1995) The functional characterization of interleukin-10 receptor expression on human natural killer cells. Blood. 85:35773585.

Cerezuela R., Guardiola F. A., Cuesta A., Esteban M. A. (2016) Enrichment of gilthead seabream (Sparus aurata L.) diet with palm fruit extracts and probiotics: Effects on skin mucosal immunity. Fish Shellfish Immunol. 49:100109.

Costa G., Danz H., Kataria P., Bromage E. (2012) A holistic view of the dynamisms of teleost IgM: A case study of Streptococcus iniae vaccinated rainbow trout (Oncorhynchus mykiss). Dev Comp Immunol. 36:298-305.

Cuadrado M., Marques A., Diamant A., Sitjà-Bobadilla A., Palenzuela O., Álvarez-Pellitero P., Padrós F., Crespo S. (2008) Ultrastructure of Enteromyxum leei (Diamant, Lom, \& Dyková, 1994) (Myxozoa), an enteric parasite infecting gilthead sea bream (Sparus aurata) and sharpsnout sea bream (Diplodus puntazzo). J Eukaryot Microbiol. 55:178-184.

Cuadrado M. (2010) Enteromixosi produïda per Enteromyxum leei (Diamant, Lom i Dyková, 1994) en espàrids d'interès comercial del Mediterrani, Departament de Biologia Animal, de Biologia Vegetal i d’Ecologia, Facultad de Cienciès. Ph. D. thesis, Universitat Autònoma de Barcelona, Barcelona, Spain. pp. 180.

Cuesta A., Esteban M. A., Meseguer J. (2006c) Cloning, distribution and up-regulation of the teleost fish MHC class II alpha suggests a role for granulocytes as antigen-presenting cells. Mol Immunol. 43:1275-1285. 
Cuesta A., Muñoz P., Rodríguez A., Salinas I., Sitjà-Bobadilla A., Álvarez-Pellitero P., Esteban M. A., Meseguer J. (2006a) Gilthead seabream (Sparus aurata L.) innate defence against the parasite Enteromyxum leei (Myxozoa). Parasitology. 132:95-104.

Cuesta A., Salinas I., Rodríguez A., Muñoz P., Sitjà-Bobadilla A., Álvarez-Pellitero P., Meseguer J., Esteban M. A. (2006b) Cell-mediated cytotoxicity is the main innate immune mechanism involved in the cellular defence of gilthead seabream (Teleostei: Sparidae) against Enteromyxum leei (Myxozoa). Parasite Immunol. 28:657-665.

Davey G. C., Calduch-Giner J. A., Houeix B., Talbot A., Sitjà-Bobadilla A., Prunet P., Pérez-Sánchez J., Cairns M. T. (2011) Molecular profiling of the gilthead sea bream (Sparus aurata L.) response to chronic exposure to the myxosporean parasite Enteromyxum leei. Mol Immunol. 48:2102-2112.

De Souza E. M., Meuser-Batista M., Batista D. G., Duarte B. B., Araujo-Jorge T. C., Soeiro M. N. C. (2008) Trypanosoma cruzi: Alpha-2-macroglobulin regulates host cell apoptosis induced by the parasite infection in vitro. Exp Parasitol. 118:331-337.

Deane E. E., Woo N. Y. S. (2011) Advances and perspectives on the regulation and expression of piscine heat shock proteins. Rev Fish Biol Fisher. 21:153-185.

Diamant A. (1992) A new pathogenic histozoic Myxidium (Myxosporea) in cultured gilthead sea bream Sparus aurata L. Bull Eur Assoc Fish Pathol. 12:64-66.

Diamant A. (1995) Myxidium leei (Myxosporea) infections in sharpsnout sea bream Diplodus puntazzo (Cetti) and common sea bream Pagrus pagrus (L.) (Sparidae). 4th International Symposium of Fish Parasitology, Munich. Book of Abstracts, 8.

Estensoro I., Álvarez-Pellitero P., Sitjà-Bobadilla A. (2013a) Antigenic characterization of Enteromyxum leei (Myxozoa: Myxosporea). Dis Aquat Org. 106:149-162.

Estensoro I., Calduch-Giner J. A., Kaushik S., Pérez-Sánchez J., Sitjà-Bobadilla A. (2012a) Modulation of the IgM gene expression and the IgM immunoreactive cell distribution by the nutritional background in gilthead sea bream (Sparus aurata) challenged with Enteromyxum leei (Myxozoa). Fish Shellfish Immunol. 33:401-410.

Estensoro I., Jung-Schroers V., Álvarez-Pellitero P., Steinhagen D., Sitjà-Bobadilla A. (2013b) Effects of Enteromyxum leei (Myxozoa) infection on gilthead sea bream (Sparus aurata) (Teleostei) intestinal mucus: Glycoprotein profile and bacterial adhesion. Parasitol Res. 112:567-576.

Estensoro I., Mulero I., Redondo M. J., Álvarez-Pellitero P., Mulero V., Sitjà-Bobadilla A. (2014) Modulation of leukocytic populations of gilthead sea bream (Sparus aurata) by the intestinal parasite Enteromyxum leei (Myxozoa: Myxosporea). Parasitology.141:425-440.

Estensoro I., Redondo M. J., Salesa B., Kaushik S., Pérez-Sánchez J., Sitjà-Bobadilla A. (2012b) Effect of nutrition and Enteromyxum leei infection on gilthead sea bream Sparus aurata intestinal carbohydrate distribution. Dis Aquat Org. 100:29-42.

Eszterbauer E., Sipos D., Forro B., Bartosova P., Holzer A. S. (2013) Molecular characterization of Sphaerospora molnari (Myxozoa), the agent of gill sphaerosporosis in common carp Cyprinus carpio carpio. Dis Aquat Org. 104:59-67.

Evans D. L., Jaso-Friedmann L. (1992) Nonspecific cytotoxic cells as effectors of immunity in fish. Annu Rev Fish Dis. 2:109-121.

FAO. FAO yearbook. Fishery and Aquaculture Statistics 2016. Rome (2018). pp.104.

Ferguson H. W., Ball H. J. (1979) Epidemiological aspects of proliferative kidney disease amongst rainbow trout Salmo gairdneri Richardson in Northern Ireland. J Fish Dis. 2:219-225.

Findly R. C., Zhao X., Noe J., Camus A. C., Dickerson H. W. (2013) B cell memory following infection and challenge of channel catfish with Ichthyophthirius multifiliis. Dev Comp Immunol. 39:302-311.

Fleurance R., Sauvegrain C., Marques A., Le Breton A., Guereaud C., Cherel Y., Wyers M. (2008) Histopathological changes caused by Enteromyxum leei infection in farmed sea bream Sparus aurata. Dis Aquat Org. 79:219-228.

Golomazou E., Athanassopoulou F., Karagouni E., Tsagozis P., Tsantilas H., Vagianou S. (2006) Experimental transmission of Enteromyxum leei Diamant, Lom and Dyková, 1994 in sharpsnout sea bream, Diplodus puntazzo 
C. and the effect on some innate immune parameters. Aquaculture. 260:44-53.

Gómez D., Bartholomew J. L., Sunyer J. O. (2014) Biology and mucosal immunity to myxozoans. Dev Comp Immunol. 43:243-256.

Gómez-Abellán V., Montero J., López-Muñoz A., Figueras A., Arizcun M., Mulero V., Sepulcre M. P. (2015) Professional phagocytic granulocyte-derived PGD2 regulates the resolution of inflammation in fish. Dev Comp Immunol. 52:182-191.

Grabner D. S., El-Matbouli M. (2010) Tetracapsuloides bryosalmonae (Myxozoa: Malacosporea) portal of entry into the fish host. Dis Aquat Org. 90:197-206.

Guardiola E. A., Cuesta A., Meseguer J., Martínez S., Martínez-Sánchez M. J., Pérez-Sirvent C., Esteban M. A. (2013) Accumulation, histopathology and immunotoxicological effects of waterborne cadmium on gilthead seabream (Sparus aurata). Fish Shellfish Immunol. 35:792-800.

Havixbeck J. J., Barreda D. R. (2015) Neutrophil development, migration, and function in teleost fish. Biology. 4:715-734.

Havixbeck J. J., Rieger A. M., Wong M. E., Hodgkinson J. W., Barreda D. R. (2016) Neutrophil contributions to the induction and regulation of the acute inflammatory response in teleost fish. J Leukoc Biol. 99:241-252.

Holzer A. S., Sommerville C., Wootten R. (2006) Molecular studies on the seasonal occurrence and development of five myxozoans in farmed Salmo trutta L. Parasitology. 132:193-205.

Hossain M. S., Koshio S., Ishikawa M., Yokoyama S., Sony N. M., Dossou S., Wang W. (2018) Influence of dietary inosine and vitamin C supplementation on growth, blood chemistry, oxidative stress, innate and adaptive immune responses of red sea bream, Pagrus major juvenile. Fish Shellfish Immunol. 82:92-100.

Jones S. R. M., Cho S., Nguyen J., Mahony A. (2016) Acquired resistance to Kudoa thyrsites in Atlantic salmon Salmo salar following recovery from a primary infection with the parasite. Aquaculture. 451:457-462.

Joosten P. H. M., Avilestrigueros M., Sorgeloos P., Rombout J. (1995) Oral vaccination of juvenile carp (Cyprinus carpio) and gilthead seabream (Sparus aurata) with bioencapsulated Vibrio anguillarum bacterin. Fish Shellfish Immunol. 5:289-299.

Kassambara A., Mundt F. (2017) Factoextra: Extract and Visualize the Results of Multivariate Data Analyses. http://www.sthda.com/english/rpkgs/factoextra (accessed August 2018).

Katzenback B. A., Plouffe D. A., Belosevic M. (2013) Goldfish (Carassius auratus L.) possess natural antibodies with trypanocidal activity towards Trypanosoma carassii in vitro. Fish Shellfish Immunol. 34:1025-1032.

Le Breton A., Marques A. (1995) Occurrence of an histozoic Myxidium infection in two marine cultured species: Puntazzo puntazzo C. and Pagrus major. Bull Eur Assoc Fish Pathol. 15:210-212.

Livak K. J., Schmittgen T. D. (2001) Analysis of relative gene expression data using real-time quantitative PCR and the $2^{-\Delta \Delta \mathrm{CT}}$ method. Methods. 25:402-408.

Magariños B., Romalde J. L., Santos Y., Casal J. F., Barja J. L., Toranzo A. E. (1994) Vaccination trials on gilthead seabream (Sparus aurata) against Pasteurella piscicida. Aquaculture. 120:201-208.

Marchalonis J. J., Adelman M. K., Schluter S. F., Ramsland P. A. (2006) The antibody repertoire in evolution: Chance, selection, and continuity. Dev Comp Immunol. 30:223-247.

Marcos-López M., Ruiz C. E., Rodger H. D., O’Connor I., MacCarthy E., Esteban M. A. (2017) Local and systemic humoral immune response in farmed Atlantic salmon (Salmo salar L.) under a natural amoebic gill disease outbreak. Fish Shellfish Immunol. 66:207-216.

Meseguer J., Esteban M. A., López Ruiz A., Bielek E. (1994) Ultrastructure of nonspecific cytotoxic cells in teleosts. I. Effector-target cell binding in a marine and a freshwater species (Seabream: Sparus aurata L., and Carp: Cyprinus carpio L.). Anat Rec. 239:468-474.

Mladineo I. (2003) Myxosporidean infections in Adriatic cage-reared fish. Bull Eur Assoc Fish Pathol. 23:113-122. 
Mosser D. M., Zhang X. (2008) Interleukin-10: New perspectives on an old cytokine. Immunol Rev. 226:205-218.

Muñoz P., Cuesta A., Athanassopoulou F., Golomazou H., Crespo S., Padrós F., Sitjà-Bobadillad A., Albiñana G., Esteban M. A., Álvarez-Pellitero P., Meseguer J. (2007) Sharpsnout sea bream (Diplodus puntazzo) humoral immune response against the parasite Enteromyxum leei (Myxozoa). Fish Shellfish Immunol. 23:636-645.

Nakanishi T., Shibasaki Y., Matsuura Y. (2015) T Cells in Fish. Biology. 4:640-663.

Okamura B., Gruhl A., Bartholomew J. L. (2015) An introduction to myxozoan evolution, ecology and development, in: Okamura B., Gruhl A., and Bartholomew J.L. (Eds.) Myxozoan Evolution, Ecology and Development. Springer International, Switzerland. pp. 1-20.

Palenzuela O., Bartholomew J. L. (2002) Molecular tools for the diagnosis of Ceratomyxa shasta (Myxozoa), in: Cunningham C.O. (Ed.) Molecular Diagnosis of Salmonid Diseases. Kluwer Academic Publishers, Netherlands. pp. 285-298.

Palenzuela O., Sitjà-Bobadilla A., Álvarez-Pellitero P. (1996) Isolation and partial characterization of serum immunoglobulins from sea bass (Dicentrarchus labrax L) and gilthead sea bream (Sparus aurata L). Fish Shellfish Immunol. 6:81-94.

Parra D., Reyes-López F. E., Tort L. (2015) Mucosal immunity and B cells in teleosts: Effect of vaccination and stress. Front Immunol. 6:81-94.

Pérez-Cordón G., Estensoro I., Benedito-Palos L., Calduch-Giner J. A., Sitjà-Bobadilla A., Pérez-Sánchez J. (2014) Interleukin gene expression is strongly modulated at the local level in a fish-parasite model. Fish Shellfish Immunol. 37:201-208.

Pérez-Sánchez J., Estensoro I., Redondo M. J., Calduch-Giner J. A., Kaushik S., Sitjà-Bobadilla A. (2013) Mucins as diagnostic and prognostic biomarkers in a fish-parasite model: Transcriptional and functional analysis. PLoS One. 8:e65457.

Pérez-Sánchez J., Benedito-Palos L., Estensoro I., Petropoulos Y., Calduch-Giner J. A., Browdy C. L., Sitjà-Bobadilla A. (2015) Effects of dietary NEXT ENHANCE (R)150 on growth performance and expression of immune and intestinal integrity related genes in gilthead sea bream (Sparus aurata L.). Fish Shellfish Immunol. 44:117-128.

Piazzon M. C., Savelkoul H. F. J., Pietretti D., Wiegertjes G. F., Forlenza M. (2015) Carp Il10 has anti-inflammatory activities on phagocytes, promotes proliferation of memory $\mathrm{T}$ cells, and regulates $\mathrm{B}$ cell differentiation and antibody secretion. J Immunol. 194:187-199.

Piazzon M. C., Galindo-Villegas J., Pereiro P., Estensoro I., Calduch-Giner J. A., Gómez-Casado E., Novoa B., Mulero V., Sitjà-Bobadilla A., Pérez-Sánchez J. (2016a) Differential modulation of IgT and IgM upon parasitic, bacterial, viral, and dietary challenges in a perciform fish. Front Immunol. 7:637.

Piazzon M. C., Lutfalla G., Forlenza M. (2016b) IL10, a tale of an evolutionarily conserved cytokine across vertebrates. Crit Rev Immunol. 36:99-129.

Piazzon M. C., Wentzel A. S., Wiegertjes G. F., Forlenza M. (2017) Carp Il10a and Il10b exert identical biological activities in vitro, but are differentially regulated in vivo. Dev Comp Immunol. 67:350-360.

Piazzon M. C., Estensoro I., Calduch-Giner J. A., del Pozo R., Picard-Sánchez A., Pérez-Sánchez J., Sitjà-Bobadilla A. (2018) Hints on T cell responses in a fish-parasite model: Enteromyxum leei induces differential expression of T cell signature molecules depending on the organ and the infection status. Parasites Vectors. 11:443.

Rau L., Gantress J., Bell A., Stewart R., Horton T., Cohen N., Horton J., Robert J. (2002) Identification and characterization of Xenopus CD8 (+) T cells expressing an NK cell-associated molecule. Eur J Immunol. 32:15741583.

R-Core-Team. (2007) R: A language and environment for statistical computing. R Foundation for Statistical Computing, Vienna, Austria. https://www.R-project.org/ (accessed August 2018).

Redondo M. J., Álvarez-Pellitero P. (2010) Carbohydrate patterns in the digestive tract of Sparus aurata L. and Psetta maxima (L.) (Teleostei) parasitized by Enteromyxum leei and E. scophthalmi (Myxozoa). Parasitol Int. 59:445-453. 
Rombout J., Yang G. W., Kiron V. (2014) Adaptive immune responses at mucosal surfaces of teleost fish. Fish Shellfish Immunol. 40:634-643.

Salinas I., Abelli L., Bertoni F., Picchietti S., Roque A., Furones D., Cuesta A., Meseguer J., Esteban M. A. (2008) Monospecies and multispecies probiotic formulations produce different systemic and local immunostimulatory effects in the gilthead seabream (Sparus aurata L.). Fish Shellfish Immunol. 25:114-123.

Sarker S., Kallert D. M., Hedrick R. P., El-Matbouli M. (2015) Whirling disease revisited: Pathogenesis, parasite biology and disease intervention. Dis Aquat Org. 114:155-175.

Shinn A. P., Pratoomyot J., Bron J. E., Paladini G., Brooker E. E., Brooker A. J. (2015) Economic costs of protistan and metazoan parasites to global mariculture. Parasitology. 142:196-270.

Sinyakov M. S., Dror M., Zhevelev H. M., Margel S., Avtalion R. R. (2002) Natural antibodies and their significance in active immunization and protection against a defined pathogen in fish. Vaccine. 20:3668-3674.

Sitjà-Bobadilla A., Calduch-Giner J., Saera-Vila A., Palenzuela O., Álvarez-Pellitero P., Pérez-Sánchez J. (2008b) Chronic exposure to the parasite Enteromyxum leei (Myxozoa: Myxosporea) modulates the immune response and the expression of growth, redox and immune relevant genes in gilthead sea bream, Sparus aurata L. Fish Shellfish Immunol. 24:610-619.

Sitjà-Bobadilla A., Diamant A., Palenzuela O., Álvarez-Pellitero P. (2007a) Effect of host factors and experimental conditions on the horizontal transmission of Enteromyxum leei (Myxozoa) to gilthead sea bream, Sparus aurata L., and European sea bass, Dicentrarchus labrax (L.). J Fish Dis. 30:243-250.

Sitjà-Bobadilla A., Estensoro I., Pérez-Sánchez J. (2016) Immunity to gastrointestinal microparasites of fish. Dev Comp Immunol. 64:187-201.

Sitjà-Bobadilla A. (2008a) Living off a fish: A trade-off between parasites and the immune system. Fish Shellfish Immunol. 25:358-372.

Sitjà-Bobadilla A., Palenzuela O. (2012) Enteromyxum species. in: Woo P.T.K., Buchmann K. (Eds.) Fish Parasites: Pathology and Protection. CAB International, Oxfordshire, UK. pp. 163-176.

Sitjà-Bobadilla A., Palenzuela O., Riaza A., Macias M. A., Álvarez-Pellitero P. (2007b) Protective acquired immunity to Enteromyxum scophthalmi (myxozoa) is related to specific antibodies in Psetta maxima (L.) (Teleostei). Scan J Immunol. 66:26-34.

Sitjà-Bobadilla A., Peña-Llopis S., Gómez-Requeni P., Medale F., Kaushik S., Pérez-Sánchez J. (2005) Effect of fish meal replacement by plant protein sources on non-specific defence mechanisms and oxidative stress in gilthead sea bream (Sparus aurata). Aquaculture. 249:387-400.

Sitjà-Bobadilla A., Redondo M. J., Bermúdez R., Palenzuela O., Ferreiro I., Riaza A., Quiroga I., Nieto J. M., ÁlvarezPellitero P. (2006) Innate and adaptive immune responses of turbot, Scophthalmus maximus (L.), following experimental infection with Enteromyxum scophthalmi (Myxosporea: Myxozoa). Fish Shellfish Immunol. 21:485500 .

Sitjà-Bobadilla A., Schmidt-Posthaus H., Wahli T., Holland J. W., Secombes C. J. (2015) Fish Immune Responses to Myxozoa, in: Okamura B., Gruhl A., Bartholomew J. L. (Eds.) Myxozoan Evolution, Ecology and Development. Springer International Publishing, Switzerland. pp. 253-280.

Steinhagen D., Hespe K. (1997) Carp coccidiosis: Activity of phagocytic cells from common carp infected with Goussia carpelli. Dis Aquat Org. 31:155-159.

Stetler R. A., Gan Y., Zhang W. T., Liou A. K., Gao Y. Q., Cao G. D., Chen J. (2010) Heat shock proteins: Cellular and molecular mechanisms in the central nervous system. Prog Neurobiol. 92:184-211.

Stromsheim A., Eide D. M., Fjalestad K. T., Larsen H. J. S., Roed K. H. (1994) Genetic variation in the humoral immune response in Atlantic salmon (Salmo salar) against Aeromonas salmonicida A-layer. Vet Immunol Immunopathol. 41:341-352.

Sunyer J. O., Boshra H., Lorenzo G., Parra D., Freedman B., Bosch N. (2003) Evolution of complement as an effector system in innate and adaptive immunity. Immunol Res. 27:549-564. 
Turk V., Turk D., Dolenc I., Stoka V. (2019) Characteristics, structure, and biological role of Stefins (type-1 cystatins) of human, other mammals, and parasite origin. Acta Chim Slov. 66:5-17.

Valero Y., Mokrani D., Chaves-Pozo E., Arizcun M., Oumouna M., Meseguer J., Esteban M. A., Cuesta A. (2018) Vaccination with UV-inactivated nodavirus partly protects European sea bass against infection, while inducing few changes in immunity. Dev Comp Immunol. 86:171-179.

Woo P. T. K., Ardelli B. F. (2014) Immunity against selected piscine flagellates. Dev Comp Immunol. 43:268-279.

Xu Z., Parra D., Gómez D., Salinas I., Zhang Y. A., Jorgensen L. V., Heinecke R. D., Buchmann K., LaPatra S., Sunyer J. O. (2013) Teleost skin, an ancient mucosal surface that elicits gut-like immune responses. Proc Natl Acad Sci U S A. 110:13097-13102.

Yanagida T., Sameshima M., Nasu H., Yokoyama H., Ogawa K. (2006) Temperature effects on the development of Enteromyxum spp. (Myxozoa) in experimentally infected tiger puffer, Takifugu rubripes (Temminck \& Schlegel). J Fish Dis. 29:561-567.

Yanagida T., Palenzuela O., Hirae T., Tanaka S., Yokoyama H., Ogawa K. (2008) Myxosporean emaciation disease of cultured red sea bream Pagrus major and spotted knifejaw Oplegnathus punctatus. Fish Pathol. 43:45-48.

Ye J. M., Bromage E. S., Kaattari S. L. (2010) The strength of B cell interaction with antigen determines the degree of IgM polymerization. J Immunol. 184:844-850.

Ye J. M., Kaattari I. M., Kaattari S. L. (2011) The differential dynamics of antibody subpopulation expression during affinity maturation in a teleost. Fish Shellfish Immunol. 30:372-377.

Zhang Y. A., Salinas I., Li J., Parra D., Bjork S., Xu Z., LaPatra S. E., Bartholomew J. L., Sunyer J. O. (2010) IgT, a primitive immunoglobulin class specialized in mucosal immunity. Nat Immunol. 11:827-882. 
CHAPTER 1 


\section{SUPPLEMENTARY MATERIAL}

Supplementary Table 1: Primers used in the study. All primers have an annealing temperature of $60^{\circ} \mathrm{C}$.

\begin{tabular}{|c|c|c|c|c|}
\hline Gene name & Symbol & $\begin{array}{l}\text { Accession } \\
\text { Number }\end{array}$ & & Sequence $\left(5^{\prime}-3^{\prime}\right)$ \\
\hline \multirow{2}{*}{$\beta$ actin } & \multirow{2}{*}{$a c t \beta$} & \multirow{2}{*}{ X89920 } & $\mathrm{F}$ & TCCTGCGGAATCCATGAGA \\
\hline & & & $\mathrm{R}$ & GACGTCGCACTTCATGATGCT \\
\hline \multirow{2}{*}{$\begin{array}{l}\text { Zeta-chain-associated pro- } \\
\text { tein kinase } 70\end{array}$} & \multirow{2}{*}{ zap70 } & \multirow{2}{*}{ MF175239 } & $\mathrm{F}$ & TGGTGAAGGAGGAGATGATGAGG \\
\hline & & & $\mathrm{R}$ & GCGAACGATGTAGCGGTTGT \\
\hline \multirow{2}{*}{ Interferon gamma } & \multirow{2}{*}{$i f n v$} & \multirow{2}{*}{ MF175242 } & $\mathrm{F}$ & CTGATTCTCATGGTGGCTCTGT \\
\hline & & & $\mathrm{R}$ & CGCAGGAGGCTCTGGATG \\
\hline \multirow{2}{*}{ Interleukin 6} & \multirow{2}{*}{ il6 } & \multirow{2}{*}{ EU244588 } & $\mathrm{F}$ & TCTTGAAGGTGGTGCTGGAAGTG \\
\hline & & & $\mathrm{R}$ & AAGGACAATCTGCTGGAAGTGAGG \\
\hline \multirow{2}{*}{ Interleukin 10} & \multirow{2}{*}{ il10 } & \multirow{2}{*}{ JX976621 } & $\mathrm{F}$ & AACATCCTGGGCTTCTATCTG \\
\hline & & & $\mathrm{R}$ & GTGTCCTCCGTCTCATCTG \\
\hline \multirow{2}{*}{ Interleukin $1 \beta$} & \multirow{2}{*}{ ill $\beta$} & \multirow{2}{*}{ A/419178 } & $\mathrm{F}$ & GCGACCTACCTGCCACCTACACC \\
\hline & & & $\mathrm{R}$ & TCGTCCACCGCCTCCAGATGC \\
\hline \multirow{2}{*}{ Interleukin $17 \mathrm{a} / \mathrm{f}$} & \multirow{2}{*}{ il17a/f } & \multirow{2}{*}{ MF175237 } & $\mathrm{F}$ & СCTCTGATGGTGCGGTGATAG \\
\hline & & & $\mathrm{R}$ & CCTGATGGGTTTGCTGGGAAC \\
\hline \multirow{2}{*}{ Granzyme a } & \multirow{2}{*}{ gzma } & \multirow{2}{*}{ MF175243 } & $\mathrm{F}$ & GCCCTGATGTCTGCCAATGTGA \\
\hline & & & $\mathrm{R}$ & GCCCTCCTGAGTCCCCCTG \\
\hline & & & $\mathrm{F}$ & GCTATGGAGGCGGAGGAAGATAACA \\
\hline $\begin{array}{l}\text { Immunogioulum } \\
\text { brane) }\end{array}$ & $m I g M$ & KX599199 & $\mathrm{R}$ & $\begin{array}{l}\text { GCAGAGTGATGAGGAAGAGAAG- } \\
\text { GATGAA }\end{array}$ \\
\hline Immunoglobulin T (mem- & $m L T$ & YY500201 & $\mathrm{F}$ & AGACGATGCCAGTGAAGAGGATGAGT \\
\hline brane) & mati & 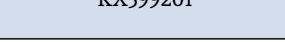 & $\mathrm{R}$ & CGAAGGAGGAGGCTGTGGACCA \\
\hline Immunoglobulin M (se- & $\operatorname{sIg} M$ & JQ811851 & $\mathrm{F}$ & $\begin{array}{l}\text { ACCTCAGCGTCCTTCAGTGTTTAT- } \\
\text { GATGCC }\end{array}$ \\
\hline & & & $\mathrm{R}$ & CAGCGTCGTCGTCAACAAGCCAAGC \\
\hline Immunoglobulin T (se- & $S I a T$ & KX599200 & $\mathrm{F}$ & GCTGTCAAGGTGGCCCCAAAAG \\
\hline creted) & sigl 1 & КА & $\mathrm{R}$ & CAACATTCATGCGAGTTACCCTTGGC \\
\hline Major Histocompatibility & mblth & MF070882 & $\mathrm{F}$ & CCTCTGGTGACGGACTGG \\
\hline Complex II $\beta$ & minuiv & 101010000 & $\mathrm{R}$ & CGATGGCGATCTTGTTTCTCTCA \\
\hline OP Mimoloulin & $2 m$ & MFo70991 & $\mathrm{F}$ & GGCACTTCCATCTGACCAAGA \\
\hline$\beta 2$ Microgiobuinn & $\beta 2 m$ & MIF $/ 9881$ & $\mathrm{R}$ & GCTGAACCGCTCTCCACG \\
\hline Protein C3 comnlement & $c 3$ & HM543456 & $\mathrm{F}$ & GCTTACGCTCTTCTTGCTCTGGTGAA \\
\hline & & & $\mathrm{R}$ & CATCTGACAACTGGTCTGGCATCGT \\
\hline Fucoloctin & & & $\mathrm{F}$ & CCATACTGCTGAACAGACCAACC \\
\hline Fucolectin & $f c l$ & KF857331 & $\mathrm{R}$ & TGATGGAGGTGACGATGTAGGA \\
\hline Macrophage mannose re- & $m r c 1$ & KF857326 250 & $\mathrm{~F}$ & CTTCCGACCGTACCTGTACCTACTCA \\
\hline ceptor 1 & miret & 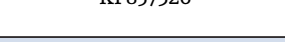 & $\mathrm{R}$ & CGATTCCAGCCTTCCGCACACTTA \\
\hline Insulin -like orowrth foctor-I & iaft & AY996779 & $\mathrm{F}$ & TGTCTAGCGCTCTTTCCTTTCA \\
\hline 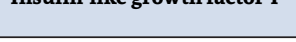 & 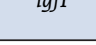 & ATPקO/I & $\mathrm{R}$ & AGAGGGTGTGGCTACAGGAGATAC \\
\hline & & & $\mathrm{F}$ & CTCACAGTTCATCGGCTACCCTATCA \\
\hline Heat Shock Protein 90 $\alpha$ & hsp90a & KM522802 & $\mathrm{R}$ & $\begin{array}{l}\text { AACTTCCTCTTCCTTCTCTCCCTCAT- } \\
\text { CAAG }\end{array}$ \\
\hline Leukocyte cysteine proteina- & lcn & SPAUU CDS NUC $062396+1^{*}$ & $\mathrm{~F}$ & TCGTGGCTGGAACAAACTACCTC \\
\hline se inhibitor 1 & MpI & 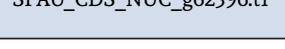 & $\mathrm{R}$ & GCTTGGAAGACCGACAGATGAATG \\
\hline Mocrobulin & $2 m$ & $4 V_{250020}$ & $\mathrm{~F}$ & TCCTGGGTGACATTCTGGGT \\
\hline प्र & nam & R1530020 & $\mathrm{R}$ & CCGTATGGCATCCTCAGCAG \\
\hline Intectinglmucin & j-mus & J027712 & $\mathrm{F}$ & GTGTGACCTCTTCCGTTA \\
\hline minesunar mucin & 1-muc & $102 / 1 / 12$ & $\mathrm{R}$ & GCAATGACAGCAATGACA \\
\hline
\end{tabular}

*Sequence obtained from the gilthead sea bream genomic database http://www.nutrigroup-iats.org/seabreamdb 
Supplementary table 2. Data for the Principal Components Analysis (PCA).

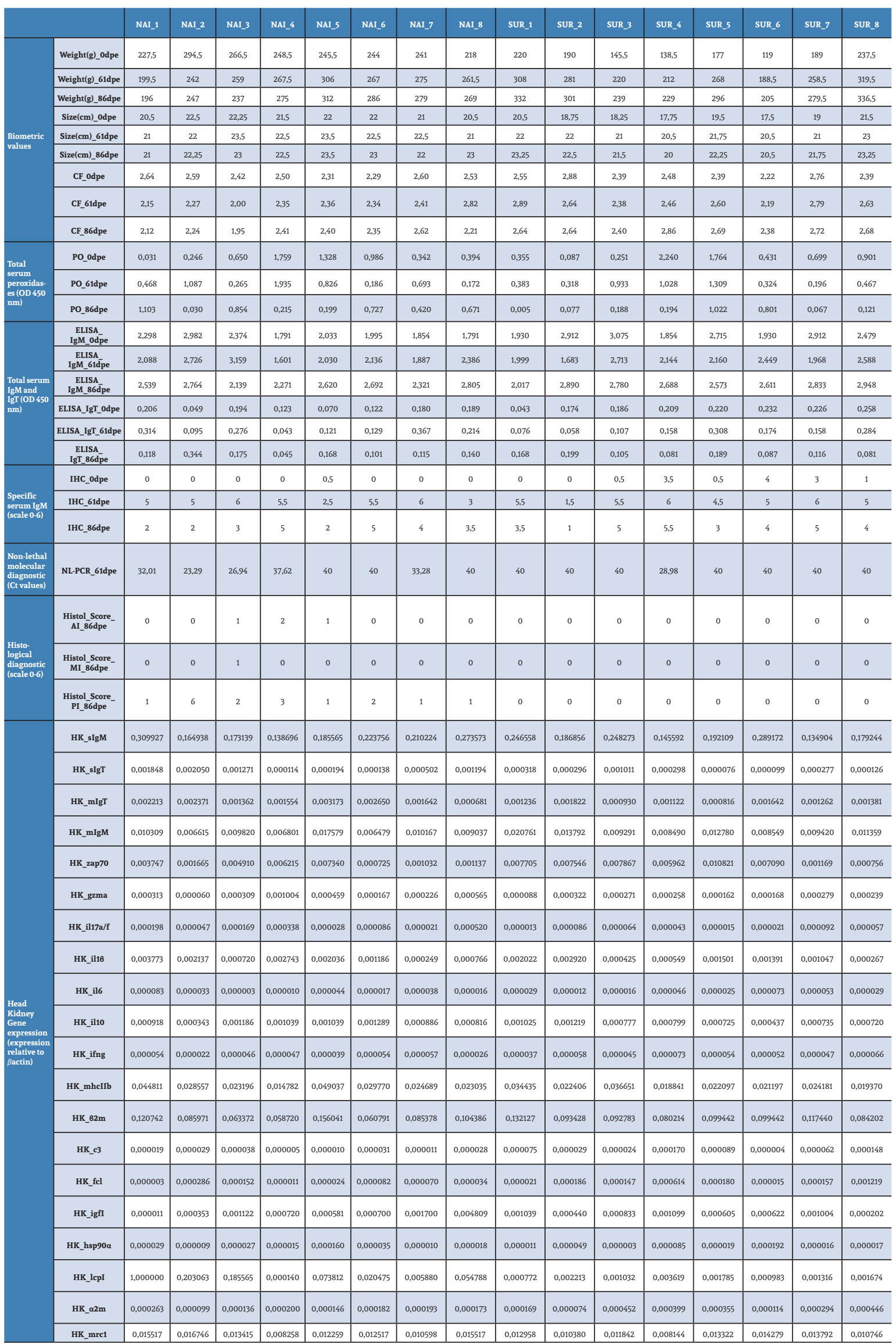




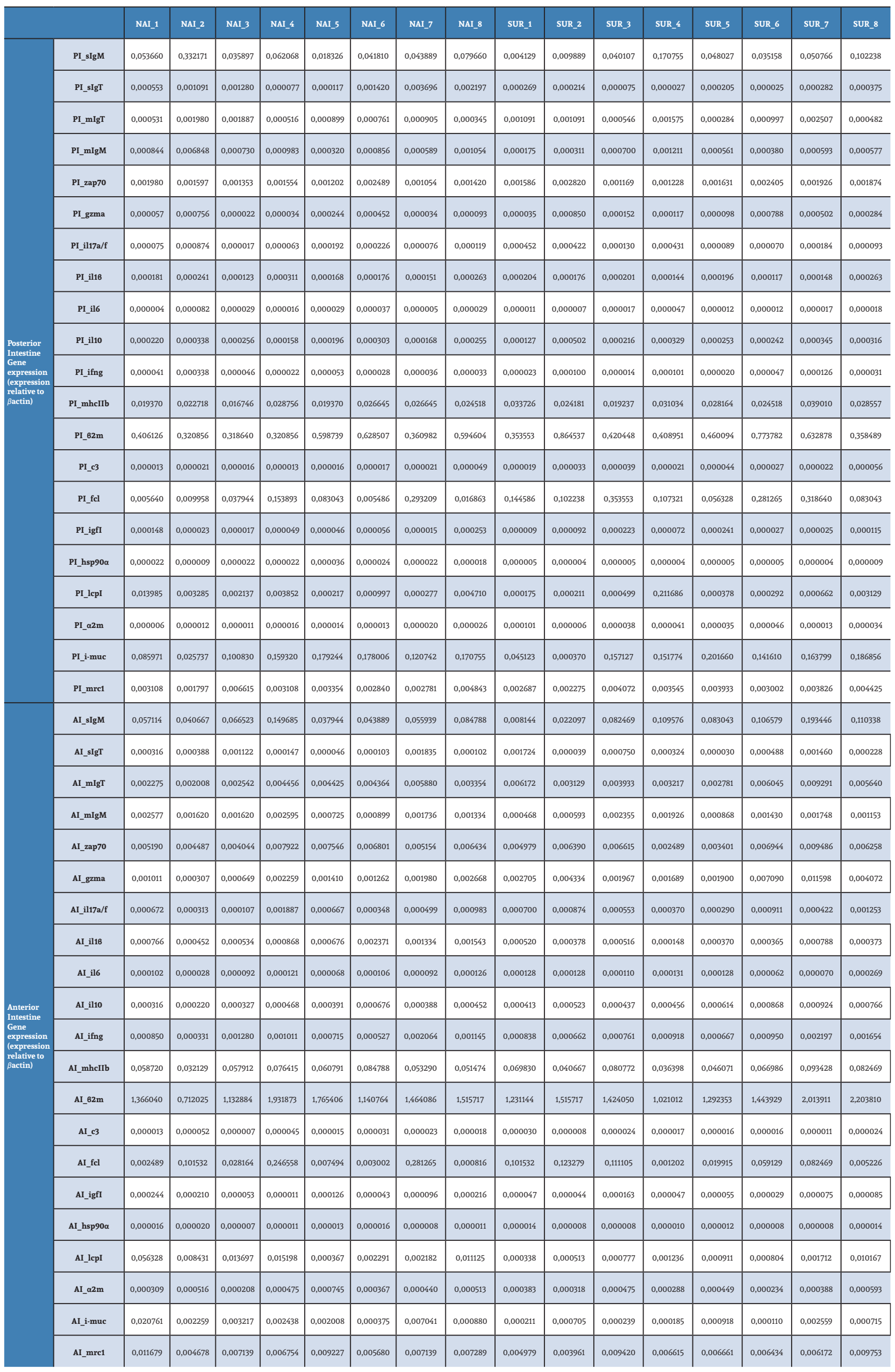


CHAPTER 1 


$$
116
$$




\section{Chapter 2}

\section{Water temperature, time of exposure and population density are key parameters in Enteromyxum leei fish- to-fish experimental transmission}

Amparo Picard-Sánchez; Itziar Estensoro; Raquel Del Pozo; Oswaldo Palenzuela; M. Carla Piazzon; Ariadna Sitjà-Bobadilla

INSTITUTO DE ACUICULTURA TORRE DE LA SAL CONSEJO SUPERIOR DE INVESTIGACIONES CIENTÍFICAS (IATS-CSIC), Torre de la Sal s/n 12595 Castellón Spain

(J Fish Dis. 43(4):491-502, 2020) 
Control of enteric parasitic diseases of farmed gilthead sea bream 


\subsection{ABSTRACT}

Enteromyxum leei is a myxozoan histozoic parasite that infects the intestine of several teleost fish species. In gilthead sea bream (Sparus aurata), it provokes a chronic disease, entailing anorexia, delayed growth, reduced marketability and mortality. Direct fish-to-fish transmission, relevant in aquaculture conditions, has been demonstrated for E. leei via effluent, cohabitation, oral and anal routes. However, the minimum time of exposure for infection has not been established, nor the possible effect on the fish immune response. Two effluent trials were performed at different temperatures (high: average of $25.6^{\circ} \mathrm{C}$, and low: constant at $\left.18^{\circ} \mathrm{C}\right)$, different times of exposure to the effluent $(1,3,5$, and 7 weeks), and different population densities. The results showed that one week was enough to infect $100 \%$ of fish at high temperature, and $58.3 \%$ at low temperature. High temperature increased the prevalence of infection in posterior intestine, but also induced a higher production of specific antibodies, limiting the progression of the infection along the intestine. Longer time of exposure to the parasite and higher fish densities facilitated E. leei infection. These results show that effective diagnosis, lowering animal density and removal of infected fish are key aspects to manage this disease in aquaculture facilities.

\section{Keywords}

Host-parasite interaction, growth delay, time of exposure, temperature, antibody. 


\subsection{INTRODUCTION}

Myxozoa are multicellular and spore-forming endoparasites that infect mainly marine and freshwater fish. Commonly, their life cycle includes two hosts; an invertebrate definitive host and a vertebrate intermediate host (Yokoyama, 2003). Definitive hosts (annelids) have only been described for a small number of myxozoan species (Fontes et al., 2015), such as Tubifex tubifex for Myxobolus cerebralis (Markiw \& Wolf, 1983) or Manayunkia speciose for Ceratonova shasta, both parasites of salmonids (Bartholomew et al., 1997). The study of myxozoans has been hampered mainly by the unavailability of in vitro cultures, and just few of them can be experimentally maintained in vivo (Abd-Elfattah et al., 2014; Eszterbauer et al., 2015; Korytář et al., 2019), including Enteromyxum leei.

E. leei, infects gilthead sea bream (Sparus aurata) among other sparids (Golomazou et al., 2006; Yanagida et al., 2008) and up to more than 60 different species, and its definitive host remains unknown. This parasite invades the intestinal epithelium, provoking chronic intestinal inflammation, causing poor food conversion rates, cachexia and eventually death (Sitjà-Bobadilla \& Palenzuela, 2012). E. leei induces a slow-progressing disease in gilthead sea bream that starts in the posterior intestine, spreading to the anterior and finally to the middle segment of the intestine (Sitjà-Bobadilla \& Palenzuela, 2012). Experimental transmission of E. leei has been described for gilthead sea bream by effluent and cohabitation (Diamant, 1997; Diamant \& Wajsbrot, 1997; Sitjà-Bobadilla et al., 2007), and anal or oral intubation of intestinal scrapings from infected fish (Diamant \& Wajsbrot, 1997; Estensoro et al., 2010). Effluent transmission involves two sources of parasite, the stages in the water from the donor tank, and the stages released from the newly infected recipient fish that become cohabitant donors. Anal intubation is a fast and homogenous transmission method, since the inoculated amount of parasites is similar in each set of experimental fish, and parasites are inoculated directly to the target tissue, the posterior intestine (Estensoro et al., 2010). However, this method could be too aggressive to test some in vivo interventions that could have a subtle effect slowing down the propagation of the parasite, such as some nutraceuticals, vaccines or passive immunization trials. Mimicking the most common route of infection in farmed fish, experimental transmission was also achieved for other fish-Enteromyxum spp. models through cohabitation/effluent of sharpsnout sea bream (Diplodus puntazzo) (Muñoz et al., 2007), tiger puffer (Takifugu rubripes) (Yasuda et al., 2002), and turbot (Scophthalmus maximus) (Redondo et al., 2002), or feeding infected gut tissue to Japanese flounder (Paralichthys olivaceus) (Yasuda et al., 2005). 
Several in vivo studies with myxozoan shave demonstrated that temperature, fish density, time of exposure and parasitic load are key parameters for the onset and development of infection (Fontes et al., 2015). Temperature is an important factor in the progression of myxozoan infections. Increased temperatures have been correlated with higher prevalence and severity of infection (de Buron et al., 2017; Udey et al., 1975). However, extreme temperatures can also supress myxozoan proliferation, either at low temperatures (Estensoro et al., 2010; Palikova et al., 2017; Yanagida et al., 2006), or high temperatures (China et al., 2014).

Parasite load can be measured in degree days, which are correlated with the time that the fish have been exposed to infective stages of the parasite and the temperature during this period (Braden et al., 2018; Jones \& Long, 2019; Thompson et al., 2010). These infective stages can be either spores from the definitive invertebrate host (Feist et al., 2001; Markiw, 1989), or proliferative stages from already infected fishes (de Buron et al., 2017; Estensoro et al., 2010). In some cases, myxozoan infections have been described to occur after very short times of exposure, ranging from minutes to days, like M. cerebralis (Markiw, 1989), Tetracapsuloides bryosalmonae (Feist et al., 2001), or Kudoa inornate (de Buron et al., 2017). However, no short term exposure trials have been conducted with E. leei yet.

In vivo experimental infection models present more contributing variables than in vitro systems, as they depend on many biotic and abiotic factors. The lack of information of how these factors interact in a given fish-parasite model challenges the standardization of experimental infections in vivo. The contribution of the different factors needs be studied in order to achieve controlled infections, and to avoid severe infections induced by extreme doses or conditions. In addition, this information will be very useful for the management of fish farms with recurrent E. leei infections.

Therefore, the aim of the present work was to determine a minimum time that gilthead sea bream needs to be exposed to E. leei-contaminated water to get infected, and show the differences in terms of prevalence and intensity of infection caused by the variables fish density and temperature. This information will help to minimize the time of exposure, resources and animal use underpinning the three R's principles of refinement, reduction and replacement (Flecknell, 2002). 


\subsection{MATERIALS AND METHODS}

\subsubsection{Fish and experimental infections}

Clinically healthy gilthead sea bream juveniles from a commercial fish farm were kept at the facilities of IATS-CSIC (Castellón, Spain) in $5 \mu \mathrm{m}$-filtered and UV irradiated sea water (salinity $37.5 \mathrm{~g} / \mathrm{L}$ ) at temperatures $\geq 18^{\circ} \mathrm{C}$, with natural photoperiod at our latitude $\left(40^{\circ} 5^{\prime} \mathrm{N} ; 0^{\circ} 10^{\prime} \mathrm{E}\right)$. The absence of $E$. leei in the stock was confirmed by qPCR according to the protocol described by Picard-Sánchez et al. (2019). Fish were fed ad libitum a commercial diet (BioMar, Palencia, Spain). Animals were kept according to the Guidelines of the European Union Council (Directive 2010/63/EU), the Spanish RD 53/2013, and the CSIC National Committee on Bioethics under approval number 2018/VSC/PEA/0240. Trial 1 (T1) started in July 2018 and lasted 92 days (average water temperature: $25.6^{\circ} \mathrm{C}$, range $22.1^{\circ} \mathrm{C}-27.5^{\circ} \mathrm{C}$ ). Trial 2 (T2) started in March 2019 and lasted 92 days (constant water temperature: $\left.18 \pm 0.5^{\circ} \mathrm{C}\right)$.

The challenges were performed by effluent exposure as previously described (Sitjà-Bobadilla et al., 2007). A schematic representation of the experimental setup can be found in Figure 1. Briefly, the trials consisted of two recipient (R) $500 \mathrm{~L}$ tanks, named R1 and R2, with 50 (T1) or 48 (T2) naïve fish each, receiving the water from a donor (D) tank holding E. leei-infected gilthead sea bream. $\mathrm{R}$ fish in both trials belonged to the same stock (initial mean body weight: $68.7 \mathrm{~g} \pm$ SD 21.9 for T1 and $102.1 \mathrm{~g} \pm$ SD 22.2 for T2). In both trials, D fish consisted of a group of 50 infected fish, positive for E. leei by qPCR (average Ct values of 24.59 SD 2.58, and 25.10 SD 3.62 for T1 and T2, respectively). The experimental setup was similar in both trials: A constant number of fish was kept in tanks holding group R1 during the entire experiment. In contrast, from tanks holding group R2, 10 (T1) or 12 (T2) fish were removed at different weeks post-exposure (wpe): 1, 3, 5, and 7 wpe in T1, and 1,3, and 5 wpe in T2. The removed groups of each trial were kept in separate $170 \mathrm{~L}$ tanks receiving parasite-free water, and were named: R2-1, R2-3, R2-5, and R2-7. The parasite load was quantified in degree-days (DD), calculated as the sum of the recorded daily temperature (measured at the same time of the day) during the exposure to the E. leei effluent, as previously used in other myxozoan studies (Braden et al., 2018; Jones \& Long, 2019). The renewal of the water in the D tank, was kept to a minimum to ensure exposure to the parasite, but without affecting water quality. In all tanks (including effluent recipient tanks), the water flow was adjusted to reach three renovations per day. In tanks R1 and R2, the effluent was not interrupted until the final sampling. 


\section{Separated from EFFLUENT}
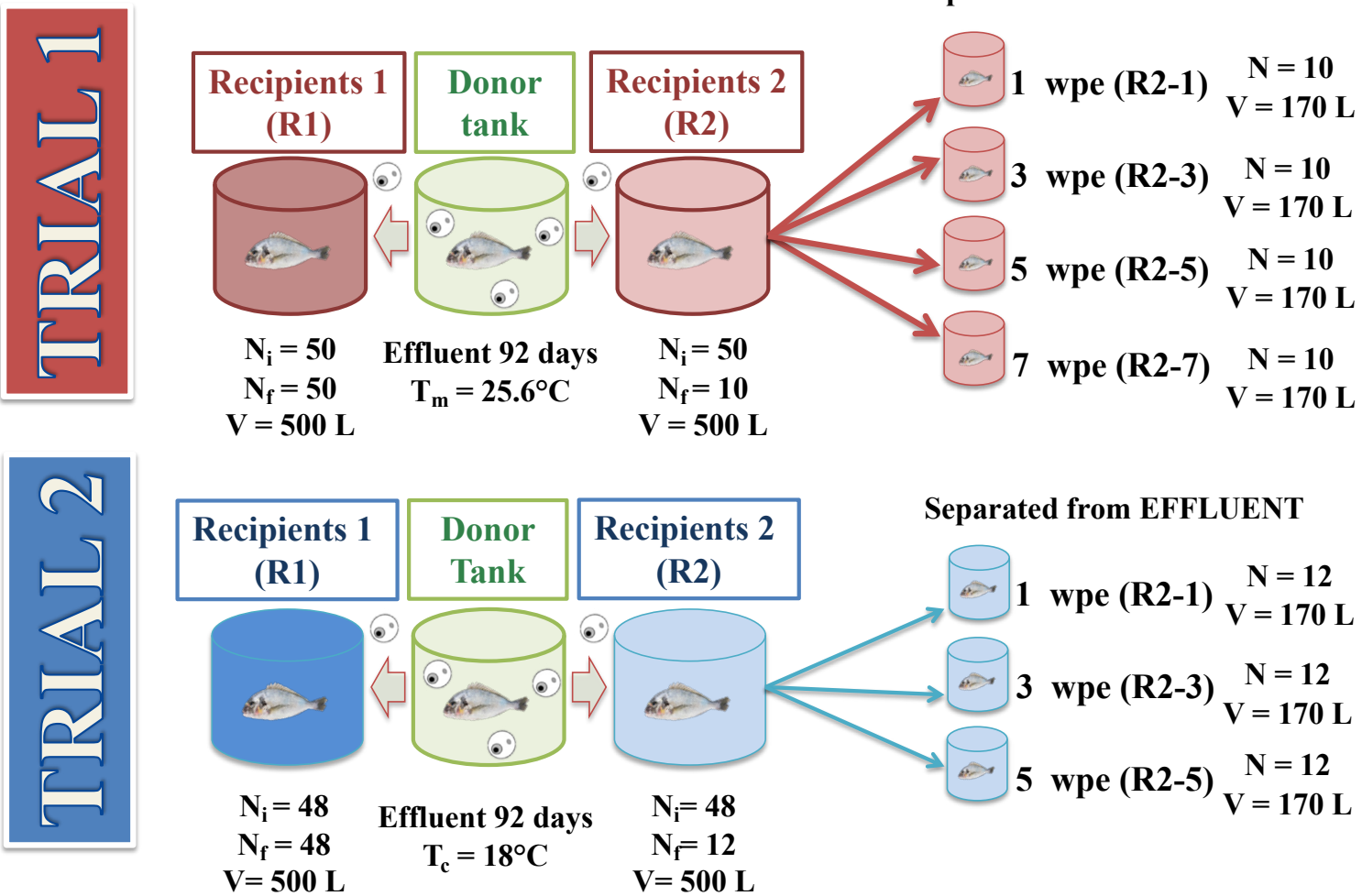

1 wpe (R2-1) $\begin{gathered}\mathrm{N}=12 \\ \mathrm{~V}=170 \mathrm{~L}\end{gathered}$

3 wpe (R2-3) $\begin{gathered}\mathrm{N}=12 \\ \mathrm{~V}=170 \mathrm{~L}\end{gathered}$

5 wpe (R2-5) $\begin{gathered}\mathrm{N}=12 \\ \mathrm{~V}=170 \mathrm{~L}\end{gathered}$

Figure 1. Schematic representation of the Enteromyxum leei infection trials in gilthead sea bream. Ni and Nf stand for initial and final number of fish, respectively. $V$ is the volume of each tank. Tm is the mean temperature for trial 1, whereas Tc is the constant temperature held in trial 2. wpe: weeks post-exposure.

\subsubsection{Samplings and parasite diagnosis}

In each trial, parasite infection was evaluated by molecular diagnosis and histology in two samplings, a non-lethal intermediate sampling at 9 wpe, and the final lethal sampling at 13 wpe. In the non-lethal samplings (9 wpe), only molecular diagnosis was performed, and at the final samplings (13 wpe), the diagnosis was performed by both methods. Fish were starved for two days before samplings, and biometric parameters were measured. The non-lethal sampling consisted of a probe of the rectal mucosa with a cotton swab and a diagnostic qPCR carried out with specific primers for E. leei 18S rRNA gene, as previously described (Piazzon et al., 2017). At the final sampling (13 wpe), fish were killed by overexposure to anaesthetic (MS222, $0.1 \mathrm{~g} / \mathrm{L}$; Sigma), and blood and intestinal tissue samples were obtained. Blood samples $(1 \mathrm{ml})$ were taken from the caudal vessels by puncture with heparinized sterile needles. After overnight clotting at $4^{\circ} \mathrm{C}$ and centrifugation at $3,000 \times \mathrm{g}$ for 30 $\mathrm{min}$, sera were recovered and maintained at $-80^{\circ} \mathrm{C}$ until further use. Tissue samples were processed for molecular and histological diagnostics, as previously described (Picard-Sánchez et al., 2019). For histology, small portions (3-4 mm) of anterior (AI), middle (MI) and posterior (PI) intestine from all fish were fixed in 10\% buffered 
formalin for standard histological procedures. DNA from the remaining intestine was extracted using the High Pure PCR Template Preparation Kit (Roche Diagnostic $\mathrm{GmbH}$, Mannheim, Germany) following the manufacturer's instructions. Infection intensity was semiquantitatively evaluated on Giemsa stained histological sections using a scale from 1 (lowest) to 6 (highest), as previously described (Estensoro et al., 2010). A fish was considered positive for the infection, when the parasite was found at least in one intestinal segment.

\subsubsection{Detection of parasite-specific IgM in serum}

Specific IgM against E. leei in serum was measured by immunohistochemistry (IHC), as previously described (Picard-Sánchez et al., 2019). Briefly, paraffin embedded sections of an E. leei-infected gilthead sea bream intestine obtained from a previous infection were used as an antigen sample, and the sera from the current study as a primary antibody. Each serum sample was tested in duplicate. Negative immunoreactive controls were carried out using serum of fish not exposed to the parasite. Negative controls were carried out omitting the fish serum, the primary and secondary antibodies or the avidin-biotin-complex. No signal was detected in any of these controls. Intensity of immunoreactivity of each fish serum against the parasite was evaluated by microscopic examination of the immunolabelled tissue sections according to a semiquantitative scale ranging from 0 to 6 as described in Picard-Sánchez et al. (2019).

\subsubsection{Data analysis and statistics}

Differences in biometrical parameters, parasite infection values, and specific circulating antibodies (IgM), among groups were evaluated within each sampling ( 9 wpe and 13 wpe), and each trial (T1 and T2). Continuous variables were analysed by one-way analyses of variance (ANOVA-I) followed by Student-Newman-Keuls test. Data which failed the normality or equal variance test were analysed with Kruskal-Wallis ANOVA-I on ranks followed by Dunn's method. Two-way ANOVA was used to compare levels of specific antibodies between trials. Chi-squared test was used to evaluate differences in proportions (prevalence). Statistical significance was assumed in all tests when $p<0.05$. All the data were analysed with GraphPad Prism 8 and SigmaPlot 14.0. Hierarchical clustering (hclust) and correlations were performed using R statistical software (v3.5.2). For these analyses, the mean values of all the parameters measured were included (Supplementary Table 1). For the correlation analyses, the corrplot package was used and the cor.test function was applied to compute significant correlation coefficients with a confidence level of 0.95. Visualizations were constructed using the factoextra (v.1.0.5) and ggplot2 (3.2.0) $\mathrm{R}$ packages. 


\subsection{RESULTS}

\subsubsection{Abiotic factors}

R1 and R2 were continuously exposed to the effluent in both trials, but each trial with a different temperature regime, which was translated into higher degree days (DD) in $\mathrm{T} 1$ (natural summer temperatures) than in $\mathrm{T} 2$ (constant $18^{\circ} \mathrm{C}$ ). DD in $\mathrm{T} 2$ at the final sampling (13 wpe) were almost equal to those of $\mathrm{T} 1$ at the intermediate sampling (9 wpe) (1638 vs 1680 DD) (Table 1). However, subgroups resulting after R2 removals at the different time points received different DD (205.9, 585.9, 942.6, 1317 in T1; and 126, 378, 630 in T2) according to the time of exposure (1, 3, 5 or 7 (only in T1) weeks, respectively) (Table 1). The number of fish in R1 groups was kept constant ( $\mathrm{n}=$ 50 for T1; $\mathrm{n}=48$ for T2), whereas R2 groups ended up with 10 (T1) or 12 (T2) fish. Thus, their population density was also different and affected the course of the infection (see below) (Table 1).

Table 1. Biometric data from trials 1 and 2 at 9 and 13 weeks post-exposure (wpe) to Enteromyxum leei. R1 was the tank from where no fish were removed during the experiment, whereas R2 represents the tank from which subgroups of fish were removed at 1 (R2-1), 3 (R2-3), 5 (R2-5) and 7 (R2-7, only in T1) wpe. CF: Condition factor. DD: Degree days. Density: Fish body mass per water volume of each tank. Data are presented as mean \pm SEM of $n=10$ (T1) or $n=12$ (T2) individuals. Comparisons were made for each sampling point among individuals belonging to the same trial (one-way ANOVA + SNK test). Different letters indicate statistically significant differences within each group $(p<0.05)$.

\begin{tabular}{|c|c|c|c|c|c|c|c|c|c|c|c|}
\hline & & \multicolumn{5}{|c|}{9 wpe } & \multicolumn{5}{|c|}{13 wpe } \\
\hline Trial & Group & Weight (g) & Size $(\mathrm{cm})$ & CF & DD & $\begin{array}{c}\text { Den- } \\
\text { sity } \\
(\mathrm{kg} / \mathrm{L})\end{array}$ & Weight (g) & Size $(\mathrm{cm})$ & CF & DD & $\begin{array}{c}\text { Density } \\
(\mathrm{kg} / \mathrm{L})\end{array}$ \\
\hline \multirow{6}{*}{$\begin{array}{c}\mathrm{T} 1 \\
\left(25.6^{\circ} \mathrm{C}\right)\end{array}$} & T1R1 & $114.7 \pm 9.0$ & $16.7 \pm 0.4$ & $2.42 \pm 0.10$ & 1680.5 & 0.0115 & $112.3 \pm 10.9$ & $16.2 \pm 0.4$ & $2.58 \pm 0.10$ & 2348.3 & 0.1120 \\
\hline & T1R2 & $98.0 \pm 8.4$ & $15.9 \pm 0.4$ & $2.41 \pm 0.03$ & 1680.5 & 0.0019 & $119.5 \pm 10.7$ & $16.7 \pm 0.5$ & $2.54 \pm 0.05$ & 2348.3 & 0.0024 \\
\hline & T1R2-1 & $116.8 \pm 7.9$ & $16.8 \pm 0.4$ & $2.41 \pm 0.05$ & 205.9 & 0.0058 & $141.0 \pm 13.2$ & $17.8 \pm 0.6$ & $2.44 \pm 0.03$ & 205.9 & 0.0071 \\
\hline & T1R2-3 & $106.5 \pm 7.0$ & $16.1 \pm 0.4$ & $2.51 \pm 0.04$ & 585.9 & 0.0053 & $130.3 \pm 8.5$ & $17.2 \pm 0.4$ & $2.53 \pm 0.10$ & 585.9 & 0.0065 \\
\hline & T1R2-5 & $104.0 \pm 9.5$ & $16.1 \pm 0.5$ & $2.41 \pm 0.04$ & 942.6 & 0.0052 & $120.6 \pm 12.5$ & $16.9 \pm 0.5$ & $2.42 \pm 0.10$ & 942.6 & 0.0060 \\
\hline & T1R2-7 & $96.9 \pm 7.3$ & $15.9 \pm 0.4$ & $2.38 \pm 0.04$ & 1317.0 & 0.0048 & $109.9 \pm 12.4$ & $16.3 \pm 0.5$ & $2.47 \pm 0.10$ & 1317.0 & 0.0055 \\
\hline \multirow{5}{*}{$\begin{array}{c}\mathrm{T} 2 \\
\left(18^{\circ} \mathrm{C}\right)\end{array}$} & T2R1 & $117.8 \pm 3.7^{\mathrm{a}}$ & $17.2 \pm 0.2$ & $\begin{array}{c}2.28 \\
\pm 0.02^{\mathrm{a}} \\
\end{array}$ & 1134.0 & 0.0113 & $127.7 \pm 4.0^{\mathrm{a}}$ & $17.8 \pm 0.2$ & $2.27 \pm 0.04^{\mathrm{a}}$ & 1638.0 & 0.0123 \\
\hline & T2R2 & $141.5 \pm 7.4^{b}$ & $18.0 \pm 0.4$ & $2.45 \pm 0.05^{b}$ & 1134.0 & 0.0034 & $161.9 \pm 11.0^{b}$ & $18.6 \pm 0.4$ & $2.49 \pm 0.05^{b}$ & 1638.0 & 0.0039 \\
\hline & T2R2-1 & $131.5 \pm 7.2^{\mathrm{ab}}$ & $17.3 \pm 0.2$ & $2.55 \pm 0.04^{b}$ & 126.0 & 0.0079 & $153.3 \pm 6.7^{\mathrm{ab}}$ & $18.2 \pm 0.2$ & $2.55 \pm 0.04^{\mathrm{b}}$ & 126.0 & 0.0092 \\
\hline & T2R2-3 & $136.3 \pm 7.3^{\mathrm{ab}}$ & $17.6 \pm 0.3$ & $\begin{array}{r}2.48 \\
\pm 0.05^{\mathrm{b}} \\
\end{array}$ & 378.0 & 0.0082 & $152.0 \pm 7.8^{\mathrm{ab}}$ & $18.4 \pm 0.3$ & $2.43 \pm 0.05^{\mathrm{ab}}$ & 378.0 & 0.0091 \\
\hline & T2R2-5 & $141.1 \pm 6.1^{b}$ & $17.6 \pm 0.3$ & $2.56 \pm 0.05^{b}$ & 630.0 & 0.0078 & $161.8 \pm 7.7^{b}$ & $18.6 \pm 0.3$ & $2.51 \pm 0.04^{b}$ & 630.0 & 0.0089 \\
\hline
\end{tabular}




\subsubsection{Growth parameters}

In T1, there were no statistically significant differences in weight, size and condition factor (CF: (100x body weight)/fork length ${ }^{3}$ ) among groups in either of the two sampling points. In T2, at both sampling points, the weight of R1 (the group that remained with a constant number of fish) was significantly lower than R2 and R2-5 groups. CF of R1 was statistically lower than all the other groups (R2, R2-1, R2-3 and R2-5) at 9 wpe. Those differences remained at 13 wpe except for R2-3. No differences were detected in size in either of the samplings (Table 1).

\subsubsection{Parasite diagnosis}

Molecular diagnosis showed high prevalence of E. leei infection in T1, particularly at the final sampling point, when all the groups reached at least $80 \%$ of prevalence of infection (Table 2). There were no differences in prevalence or in intensity of infection among groups in either of the sampling points. In T2, however, significant differences were observed in prevalence of infection at the intermediate sampling, showing R2-1 (only exposed for 1 week) the lowest value. This trend was maintained at the final sampling, but the statistical significance was lost. However, at the final sampling, R1 group (the group with higher density and continuously exposed to the parasite-contaminated effluent), showed a significantly higher intensity of infection than R2-1 group (fish exposed only for one week) (Table 2). When comparing both trials, a slower progression of the infection was observed in T2, with lower prevalence of infection than in T1 in all the groups except T2R1, particularly at the first sampling point. The intensity of infection in T2R1 was strikingly higher than that of T1R1 $(>10$ $\mathrm{Ct}$ values), even though they showed the same prevalence of infection.

The histological diagnosis performed at the final sampling added valuable information on the progression of the infection along the intestine. In T1, no differences in prevalence, intensity and progression of the infection were detected among groups (Table 2). Of note, none of the fish exposed for only 1 or 3 weeks, acquired the infection at the middle intestine, which is the last intestinal segment invaded by the parasite (Figure 2A, C; Table 2). In T2, the contingency test revealed a significant relationship between the prevalence of infection and the time of exposure in all the intestinal segments (Table 2). In addition, the progression of the infection also differed from that in T1, as the percentage of fish with all the intestinal segments infected was higher in T2, especially in R1 and R2-5 (Figure 2C, D). Furthermore, a clear significant increase of the prevalence of infection with the time of exposure was noticed in both, when analysing the percentage of fish with more than one, and more than two infected intestinal segments (Figure 2B, D). Again, fish exposed only for one week showed the lowest prevalence and progression of the infection, whereas the highest were found in R1 group (Table 2 and Figure 2B, D). 
Table 2. Enteromyxum leei infection. Molecular diagnosis was performed by qPCR at 9 (non-lethal) and 13 weeks post-exposure (wpe). Histological diagnosis was performed by examination of anterior (AI), middle (MI) and posterior intestine (PI), at the final sampling (13 wpe). R1 was the tank from where no fish were removed during the experiment, whereas R2 represents the tank from which subgroups of fish were removed at 1 (R2-1), 3 (R2-3), 5 (R2-5) and 7 (R2-7, only in T1) wpe. Values for prevalence of infection are presented as percentage of infected fish from sampled fish. Values for intensity of infection are presented as the mean \pm SEM. Comparisons were made for each sampling point among individuals of the same trial. Asterisks indicate a statistically significant correlation within a sampling point (Chi-squared test, $p<0.05$ ). Different letters indicate statistically significant differences within each group (one-way ANOVA on ranks + Dunn's test $p<0.05$ ).

\begin{tabular}{|c|c|c|c|c|c|c|c|c|c|c|c|}
\hline \multirow[t]{3}{*}{ Trial } & \multirow[t]{3}{*}{ Group } & \multicolumn{4}{|c|}{ Molecular diagnosis (qPCR) } & \multicolumn{6}{|c|}{ Histology (13 wpe) } \\
\hline & & \multicolumn{2}{|c|}{ Prevalence (\%) } & \multicolumn{2}{|c|}{ Intensity (Ct) } & \multicolumn{3}{|c|}{ Prevalence (\%) } & \multicolumn{3}{|c|}{ Intensity (0-6) } \\
\hline & & 9 wpe & 13 wpe & 9 wpe & 13 wpe & $\mathrm{AI}$ & MI & PI & $\mathrm{AI}$ & MI & PI \\
\hline \multirow{6}{*}{$\begin{array}{c}\mathrm{T} 1 \\
\left(25.6^{\circ} \mathrm{C}\right)\end{array}$} & T1R1 & 70 & 90 & $28.1 \pm 1.8$ & $32.9 \pm 1.6$ & 30 & 20 & 50 & $3.3 \pm 1.2$ & $1.0 \pm 0.0$ & $4.0 \pm 1.2$ \\
\hline & T1R2 & 50 & 90 & $28.0 \pm 1.9$ & $31.0 \pm 2.4$ & 33 & 11 & 67 & $3.7 \pm 1.2$ & $6.0 \pm 0.0$ & $4.0 \pm 1.2$ \\
\hline & T1R2-1 & 50 & 100 & $26.6 \pm 0.6$ & $27.7 \pm 1.5$ & 30 & 0 & 70 & $2.3 \pm 0.3$ & $0.0 \pm 0.0$ & $5.1 \pm 0.6$ \\
\hline & T1R2-3 & 30 & 80 & $31.9 \pm 2.8$ & $28.4 \pm 1.5$ & 10 & 0 & 30 & $5.0 \pm 0.0$ & $0.0 \pm 0.0$ & $4.0 \pm 1.5$ \\
\hline & T1R2-5 & 70 & 90 & $26.9 \pm 1.2$ & $30.0 \pm 1.9$ & 40 & 10 & 60 & $3.0 \pm 1.2$ & $1.0 \pm 0.0$ & $3.7 \pm 1.1$ \\
\hline & T1R2-7 & 80 & 100 & $27.2 \pm 1.3$ & $29.5 \pm 1.6$ & 40 & 20 & 60 & $4.8 \pm 1.3$ & $5.5 \pm 0.5$ & $4.3 \pm 1.1$ \\
\hline \multirow{5}{*}{$\begin{array}{c}\mathrm{T} 2 \\
\left(18^{\circ} \mathrm{C}\right)\end{array}$} & T2R1 & $72^{*}$ & 100 & $27.7 \pm 0.8$ & $20.5 \pm 0.7^{a}$ & $100^{*}$ & $67^{*}$ & $100^{*}$ & $4.8 \pm 0.6$ & $5.3 \pm 0.4$ & $5.8 \pm 0.1$ \\
\hline & T2R2 & $17^{*}$ & 83 & $24.8 \pm 0.7$ & $27.2 \pm 2.4^{\mathrm{ab}}$ & $25^{*}$ & $0^{*}$ & $100^{*}$ & $2.3 \pm 1.3$ & $0.0 \pm 0.0$ & $3.0 \pm 0.6$ \\
\hline & T2R2-1 & $8^{*}$ & 58 & $24.1 \pm 0.0$ & $31.9 \pm 2.7^{b}$ & $8^{*}$ & $0^{*}$ & $58^{*}$ & $2.0 \pm 0.0$ & $0.0 \pm 0.0$ & $3.1 \pm 0.8$ \\
\hline & T2R2-3 & $33^{*}$ & 75 & $24.2 \pm 0.8$ & $25.8 \pm 2.4^{\mathrm{ab}}$ & $33^{*}$ & $17^{*}$ & $75^{*}$ & $3.5 \pm 1.2$ & $4.0 \pm 2.0$ & $4.0 \pm 0.7$ \\
\hline & T2R2-5 & $25^{*}$ & 64 & $29.1 \pm 1.7$ & $26.5 \pm 3.6^{\mathrm{ab}}$ & $36^{*}$ & $27^{*}$ & $45^{*}$ & $2.8 \pm 0.8$ & $3.3 \pm 1.2$ & $3.8 \pm 1.0$ \\
\hline
\end{tabular}


A

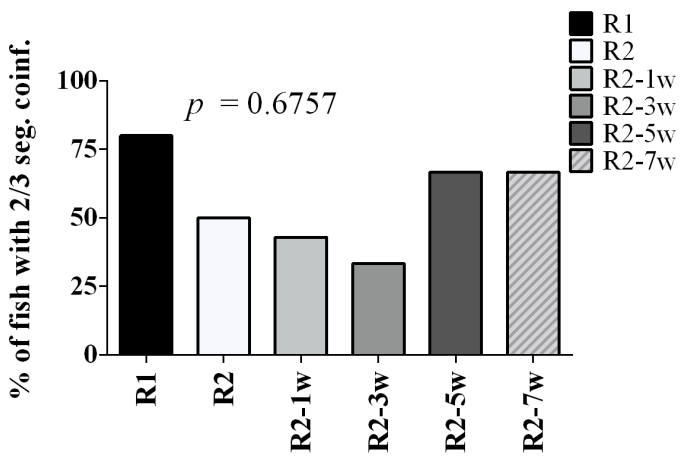

C

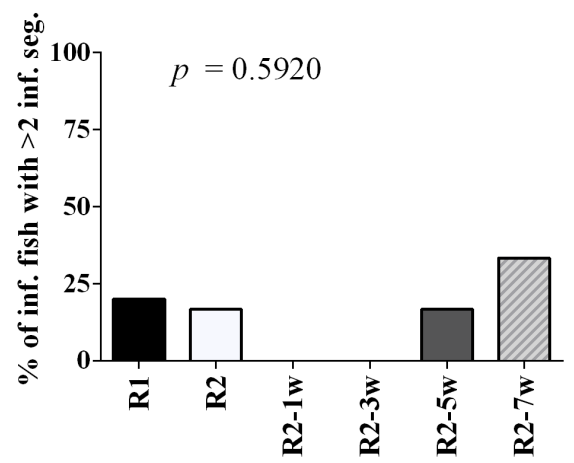

B

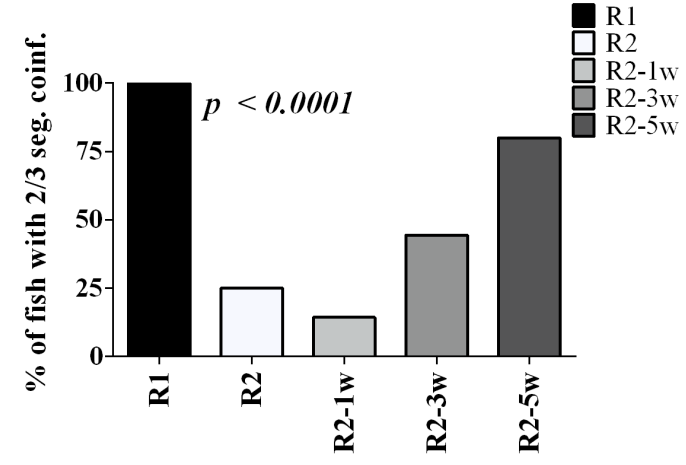

D

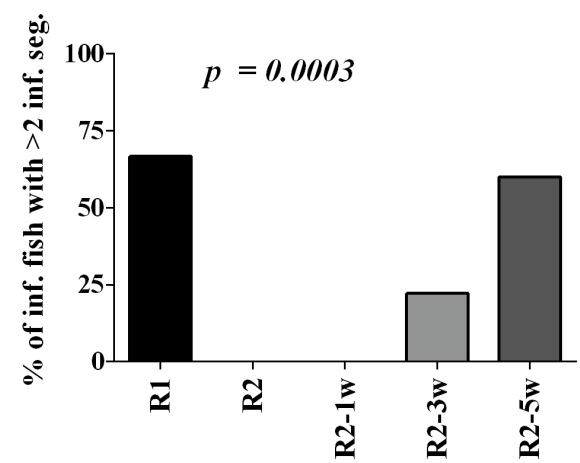

Figure 2. Intensity of Enteromyxum leei infection related to time of exposure at low temperatures. The intensity of infection was evaluated by histology as the percentage of fish with more than one intestinal segment parasitized in trial 1 (T1) with mean temperature of $25.6^{\circ} \mathrm{C}$ (A) and T2 with constant temperature of $18^{\circ} \mathrm{C}(\mathrm{B})$; or three intestinal segments parasitized in T1 (C), and T2 (D). R1 was the tank from where no fish were removed during the experiments, whereas $\mathrm{R} 2$ represents the tank from which subgroups of fish were removed at 1 (R2-1), 3 (R2-3), 5 (R2-5) and 7 (R2-7) weeks post-exposure. P-values result from a Chi-squared test to compare proportions and were considered significant when $p<0.05$ (bold). 
A

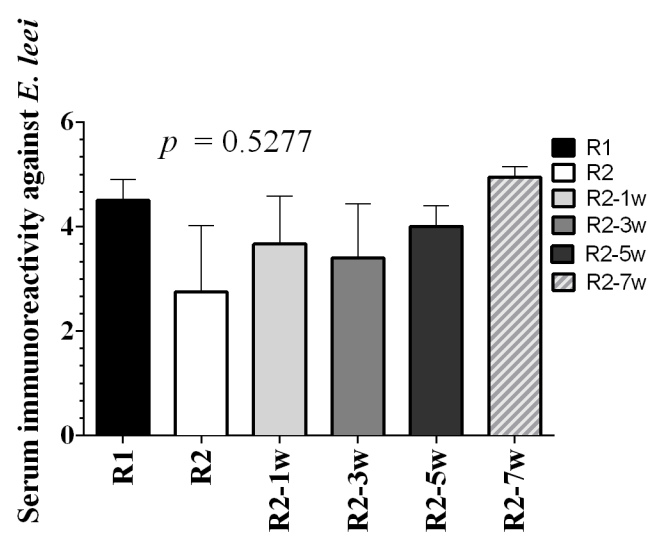

C

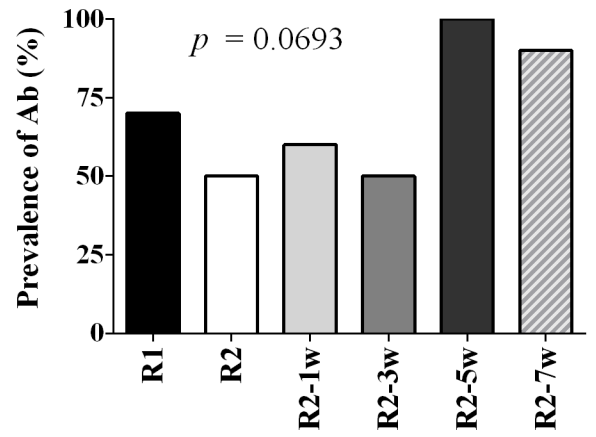

B

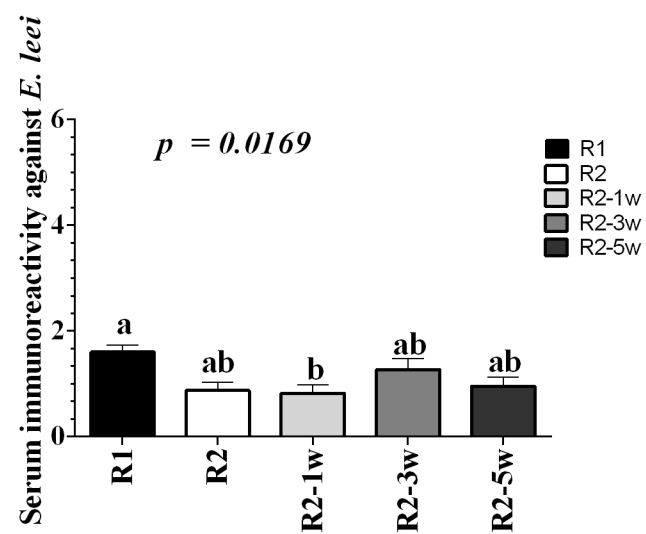

D

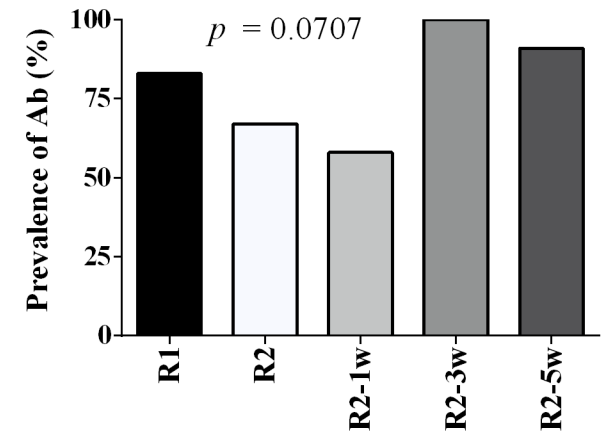

Figure 3. Production of specific antibodies related to temperature. Mean intensity of serum IgM immunoreactivity against Enteromyxum leei, measured by immunohistochemistry, for each group of gilthead sea bream from trials T1 ((A), mean temperature $\left.25.6^{\circ} \mathrm{C}\right)$ and $\mathrm{T} 2\left((\mathrm{~B})\right.$, constant temperature $\left.18^{\circ} \mathrm{C}\right)$. One-way ANOVA was used to determine statistical differences $(p<0.05)$ represented by different lower case letters. Overall, in T1 there was a higher intensity immunoreactivity than in T2 (two-way ANOVA $p<0.0001$ ). Percentage of fish with parasite-specific IgM in T1 (C) and T2 (D). P-values result from a Chi-squared test to compare proportions. R1 was the tank from where no fish were removed during the experiments, whereas R2 represents the tank from which subgroups of fish were removed at 1 (R2-1), 3 (R2-3), 5 (R2-5) and 7 (R2-7, only in T1) weeks post-exposure.

\subsubsection{Parasite-specific antibodies in serum}

The intensity of response of parasite-specific IgM in serum at the final sampling point, measured by IHC, was significantly higher in T1 than in T2 (two-way ANOVA $p<0.0001$ ). Within T1, no differences were found in antibody levels among groups (Figure 3A), whereas in T2, the group exposed for 1 week (R2-1) showed significantly lower antibody levels than R1 (constant number of fish during the experiment) (Figure 3B). No differences were detected when comparing the percentage of fish with specific antibodies among groups within each trial (Figure 3C, D). 


\subsubsection{Global analysis}

The cluster analysis of all the results obtained during the study showed a clear separation of groups by trial, as well as by their time of exposure (Figure 4). Within T1 (high water temperature), groups exposed during shorter times (1 and 3 wpe: R2-1 and R2-3) were more similar, and 5 and 7 wpe (R2-5 and R2-7) clustered closer to the continuously exposed groups (R1 and R2). At lower temperature (T2), R2-3 group was more similar to R2-5 group, and R1 group clustered closer to the high temperature groups than to the other T2 groups, due to its high prevalence of infection.

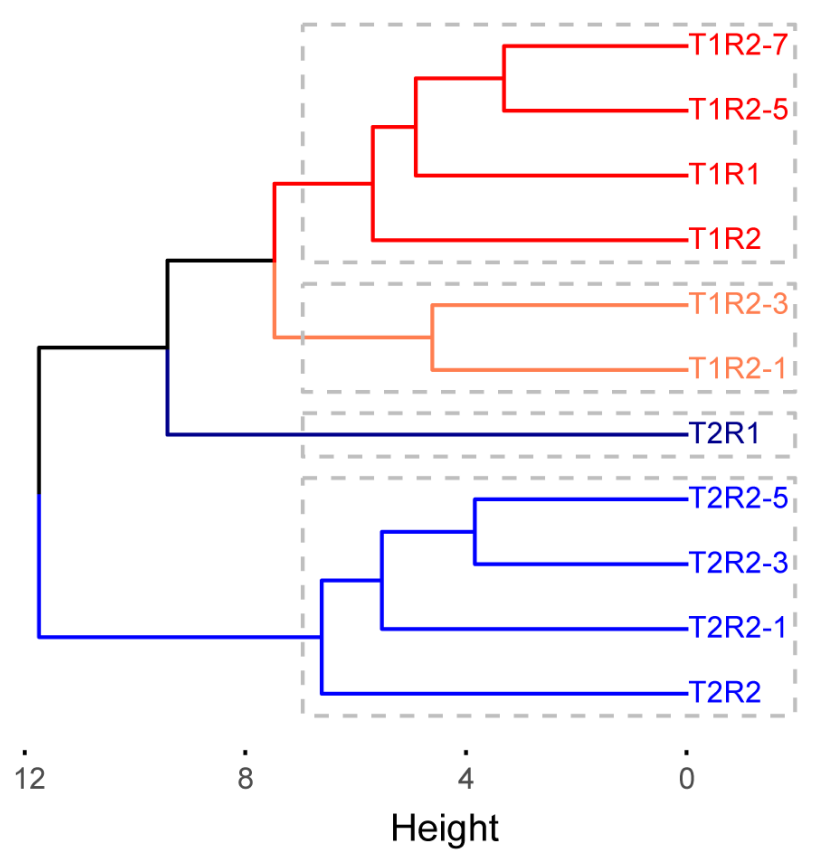

Figure 4. Temperature and time of exposure are key variables in the overall clustering of groups in Enteromyxum leei experimental infections in gilthead sea bream. Hierarchical cluster analysis performed using all the variables measured in $\mathrm{T} 1$ (mean temperature $25.6^{\circ} \mathrm{C}$ ) and $\mathrm{T} 2$ (constant temperature $18^{\circ} \mathrm{C}$ ). $\mathrm{R} 1 \mathrm{was}$ the tank from where no fish were removed during the experiments, whereas R2 represents the tank from which subgroups of fish were removed at 1 (R2-1), 3 (R2-3), 5 (R2-5) and 7 (R2-7, only in T1) weeks post-exposure.

\subsubsection{Infection status, abiotic, biotic and immune factors are correlated}

Correlations among all the different variables in the study, merging the results from both trials, showed interesting links (Figure 5). The time of exposure and DD at the intermediate sampling were negatively correlated with the condition factor, whereas DD at the final sampling showed a negative correlation with the final weight and size of the fish. The final population density in the tanks showed 
a negative correlation with the specific growth rate and a positive correlation with the percentage of fish with all the intestinal segments parasitized. Most of the biometric parameters showed negative correlations with infection diagnostic variables, which also drove a negative correlation with the presence of parasitespecific antibodies in serum. On average, the percentage of fish with specific antibodies was positively correlated with the percentage of animals with more than one intestinal segment parasitized.

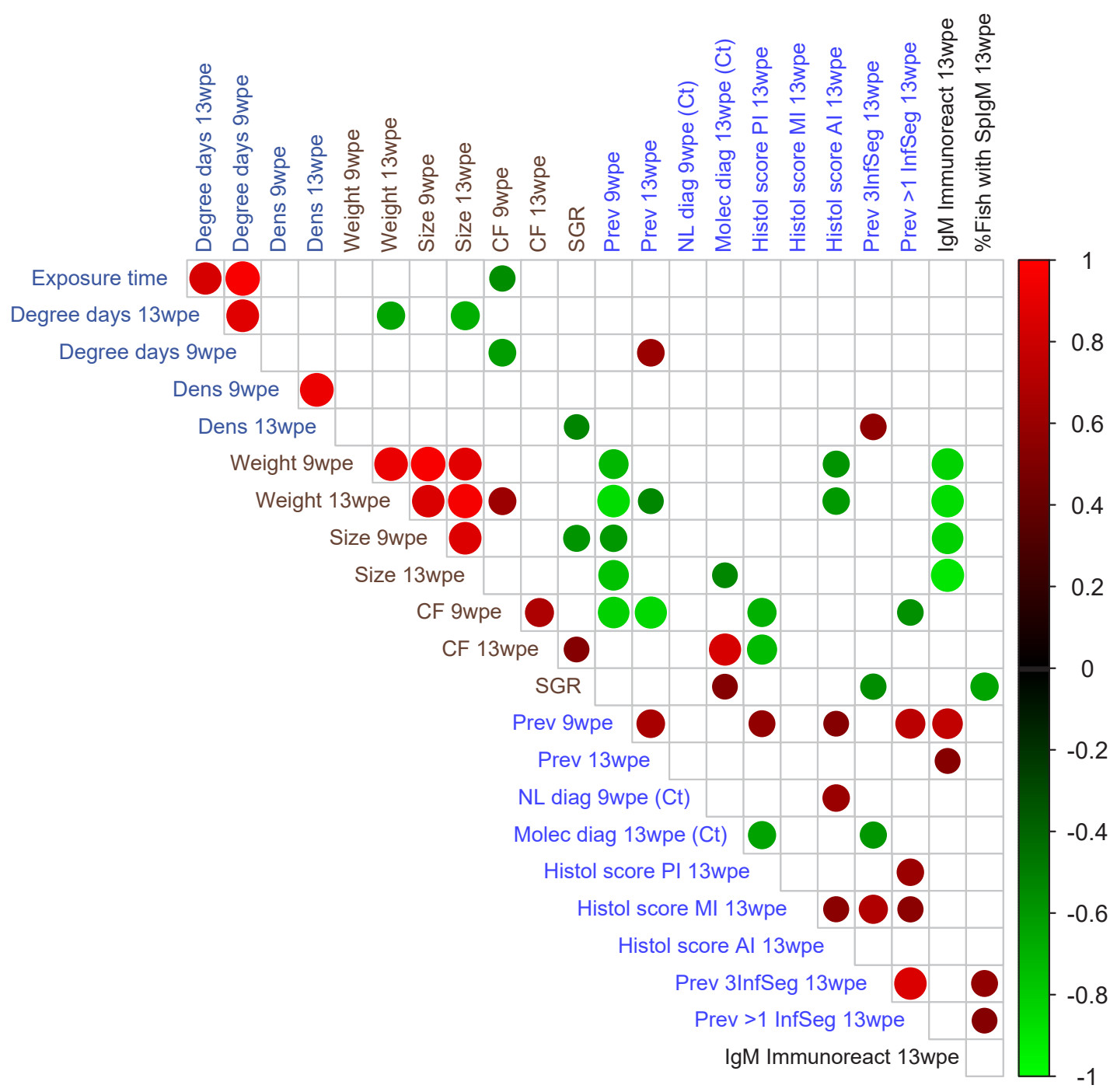

Figure 5. Correlogram highlighting the most correlated variables in the Enteromyxum leei infecting gilthead sea bream's study The color and the size of the circles represent the correlation coefficients among variables. Only statistically significant correlations are shown (Pearson's product moment correlation coefficient, $p$ $<$ 0.05). Abiotic, biotic, diagnostic and immune variables are represented in blue, brown, violet and black, respectively. Dens: density in kg of fish per liter; CF: condition factor; SGR: specific growth rate; Prev: prevalence of infection; NL diag: non-lethal molecular diagnosis measured in Ct values; Molec diag: lethal molecular diagnosis measured in Ct values; Histol score PI, MI, AI: histological scoring for posterior, middle and anterior intestine, respectively; Prev 3InfSeg: prevalence of fish with the 3 intestinal segments parasitized; Prev >1InfSeg: prevalence of fish with more than one intestinal segment parasitized; IgM Immunoreact: immunolabeling intensity measuring the amount of parasite-specific IgM in serum; \%Fish with SpIgM: percentage of fish with parasite-specific IgM in serum; wpe: weeks post-exposure. 


\subsection{DISCUSSION}

Host and parasites live in a constant struggle, and evolve together over time, both trying to win each battle. In the current host-parasite model, the speed of parasite transmission and progression, the final prevalence of infection, and the host immune status are influenced by three key aspects: water temperature, time of exposure (parasite load) and fish density (fish body mass per water volume in a tank). This study showed once more how water temperature directly influenced parasite proliferation and the immune response of gilthead sea bream. In T1, the higher temperature induced two main effects: a faster infection speed (particularly observed in groups exposed for short times) and a higher production of specific antibodies, acting as an opposing force, yielding a lower progression of the infection along the intestinal tract in T1 than in T2. Myxozoan outbreaks tend to occur from spring to autumn, when temperature starts to be warmer $\left(15^{\circ} \mathrm{C}\right.$ to $\left.20^{\circ} \mathrm{C}\right)$ (Fontes et al., 2015). Indeed, there is evidence that at cold temperatures, for the Mediterranean Sea lower than $15^{\circ} \mathrm{C}$, E. leei development and disease are suppressed (Estensoro et al., 2010; Yanagida et al., 2006). Similar effects of faster spreading due to higher temperature have already been described for other myxozoans. C. shasta in spring/summer induced higher mortalities and decreased mean days to death in chinook (Oncorhynchus tshawytscha) and coho (Oncorhynchus kisutch) salmon in the Klamath River (Ray et al., 2012). Myxobolus holzerae caused severe gill disease in Indian major carp (Labeo rohita) in spring (Gupta \& Kaur, 2017). More severe infections due to warmer water have also been described for T. bryosalmonae infecting Fredericella sultana (bryozoan host) (Tops et al., 2006), and rainbow trout (fish host) (Clifton-Hadley et al., 1984). However, there is also an upper limit, and E. leei showed to be inhibited at temperatures higher than $30^{\circ} \mathrm{C}$ (China et al., 2014).

In fish, as ectotherms, temperature influences greatly the type, speed, and intensity of the immune response (Abram et al., 2017; Le Morvan et al., 1998). Gilthead sea bream is a sparid fish mostly farmed in the Mediterranean Sea, with optimal growing temperatures between $18^{\circ} \mathrm{C}$ and $26^{\circ} \mathrm{C}$ (Colloca \& Cerasi, 2009). Thus, at $18^{\circ} \mathrm{C}$ (T2) the immune response of gilthead sea bream is not expected to be compromised, but was probably functioning at a slower pace than at $25.6^{\circ} \mathrm{C}$ (T1). This would explain the higher intensity of the humoral immune response in $\mathrm{T} 1$ fish (Figure 3). At the same time, the faster proliferation of the parasite (induced by the higher temperature) would account for a quicker invasion of the intestine and interaction with immune cells, and therefore, for inducing an earlier immune reaction. Parasite dose (antigen dose), together with location and extent of antigen presentation, are of key importance for the outcome of the immune response (Zinkernagel et al., 1997). Thus, in T1, the parasite could have been proliferating faster and fish may have developed a more intense immune response. In T1, the incipient differences (at the posterior intestine) in prevalence of infection among 
groups found at 9 wpe disappeared at 13 wpe, as all experimental groups showed very high levels (by qPCR: 80-100\%). Thus, differences among groups due to the time of exposure and population density disappeared, probably due to the fast spreading of E. leei at high temperatures. A similar effect was also found in other experiments with short exposures or low parasite loads, such as in rainbow trout exposed for $10 \mathrm{~min}$ to $M$. cerebralis actinospores released by experimentallyinfected tubificids showing a 100\% prevalence after 4 - 5 months (Markiw, 1989), or the $100 \%$ of prevalence detected in rainbow trout when exposed to five C. shasta spores (Bjork \& Bartholomew, 2009). By contrast, in T2, the lower temperature allowed detection of differences in prevalence of infection among groups due to the time of exposure and fish density by qPCR at 9 wpe, and also by histology at 13 wpe. Interestingly, despite the higher parasite prevalence at the posterior intestine in T1, there was a slower progression of the infection along the intestinal tract than in T2, which could be due to the higher levels of specific antibodies observed at high temperatures. Previous studies have described the important role of IgM in E. leei- gilthead sea bream infections, with an overexpression of IgM in posterior intestine and head kidney in infected gilthead sea bream (Piazzon et al., 2016). Another study showed that gilthead sea bream that survived an infection with $E$. leei showed high levels of parasite-specific IgM in serum, even several months after eliminating the parasite (Picard-Sánchez et al., 2019). Thus, the higher specific IgM present in serum in T1 (Figure 3), could have slowed the spreading of the parasite down, explaining why, even though $\mathrm{T} 1$ fish had higher prevalence of infection, the progression and intensity of the infection was higher in infected fish from T2. The different prevalence of infection between the different diagnostic methods (histology and qPCR) may be caused by the E. leei patchy distribution when intensity of infection was low or medium, as previously described in Estensoro et al. (2010), and the size of the tissue samples that were taken to do the molecular test (qPCR). Indeed, this occurred on in T2-R2 group, in which one fish was scored with 1+ in histology and negative by qPCR.

In this study we have shown that the shortest time of exposure tested (one week) is enough to infect all the experimental fish after 13 wpe with high water temperature $(100 \%, \mathrm{~T} 1)$, whereas it only yields half this value at lower temperature $(58.3 \%, \mathrm{~T} 2)$. Similar to this, K. inornate was also able to be transmitted after 7 days of exposure in spotted sea trout (Cynoscion nebulosus) (de Buron et al., 2017). Moreover, a parasite from the same genus, E. scophthalmi, afecting turbot was detected in intestine by cohabitation at $48 \mathrm{dpe}$, and about 8 days when it was infected per os (Redondo et al., 2002). Thus, myxozoan infections could be happening within minutes to hours of exposure. For instance, in rainbow trout (Oncorhynchus mykiss), C. shasta can be transmitted after 3 hours of exposure (Ray \& Bartholomew, 2013), T. bryosalmonae after $90 \mathrm{~min}$ (Feist et al., 2001), or M. cerebralis in only $10 \mathrm{~min}$ (Markiw, 1989). Further studies will define whether a shorter time window is feasible for E. leei infection. 
As a general trend, intestinal infection spread was lower with shorter exposure times. Both trials showed the same time-dependent progression of the infection along the intestine, and the middle segment was less parasitized at the shortest times of exposure. However, when analyzing the infection levels in all intestinal segments, there was no time effect at high temperature (T1) in terms of prevalence of infection, whereas at low temperature (T2), the effect of time was clear. Time of exposure was also negatively correlated with growth performance, according to the emaciative effect induced by E. leei infections on gilthead sea bream and olive flounder (Shin et al., 2018; Sitjà-Bobadilla \& Palenzuela, 2012). Consequently, T1R21 fish reached the highest weight, and T2R2-1 fish, the best condition factor at the end of each trial.

Presently, there are no treatments or vaccines available against myxozoan infections (Yokoyama et al., 2012), and control strategies are mostly preventive and are related to fish living conditions, such as good management techniques, reducing stock densities or improving water quality (Fontes et al., 2015). In this work, infection due to cohabitation within recipient tanks seems crucial for the speed of parasite establishment and spreading. R1 tanks had five- and four-times higher fish density and fish number than R2 tanks in T1 and T2, respectively. Moreover, R1 tanks, regardless of the temperature, had the same prevalence of infection at 9 wpe (70\%), and reached the highest infection values for all the variables studied at 13 wpe. This was particularly highlighted by the progression of the infection along the intestinal tract, since prevalence of infection at the middle intestine (the last segment being infected) was higher in R1 groups than in R2, and furthermore, in T2 this was also applicable to the anterior intestine. The main factor that could explain this phenomenon is the different probability of finding an infected fish comparing R1 and R2. In other words, in the tanks where fish were periodically removed (R2), the likelihood of parasite and host encounter decreased with the lowering animal density and, at the same time, the random removal of infected fish lowered the probability of infections by cohabitation within the tank. This work evidenced two sources of parasite in an effluent transmission model. The first source is the water from the donor tank (effluent transmission), and the second source, as a consequence of the first, are the infected cohabitant fish. Cohabitation effects can be stronger than the effluent transmission, since there is direct contact between hosts, although the exact time after infection when the parasite starts to be shed cannot be calculated. In experimental transmissions of E. leei from tiger puffer to red sea bream (Pagrus major), higher prevalence of infection was achieved by cohabitation (42\%) than by effluent exposure (25\%) (Yanagida et al., 2008). Similarly, the spreading of the infection by E. scophthalmi, was faster by cohabitation than by effluent transmission, once the infection was established (Redondo et al., 2004). Although it is not possible to quantitatively differentiate the effects of effluent from those of cohabitation, both infection 
methods must be acting at the same time because at 9 wpe, all the R2 subgroups, exposed to the effluent less time than R2 tanks, but with higher density, reached the same prevalence of infection or even higher (except T1R2-3 and T2R2-1) than R2 tanks.

In conclusion, we have shown the relevance of time of exposure, temperature, and fish density on the prevalence, intensity and progression of infection in an effluent transmission model with the parasite E. leei in gilthead sea bream. We have also shown, for the first time, that one week of exposure to a parasite-contaminated effluent is enough to effectively transmit this disease (from $18^{\circ} \mathrm{C}$ to $25.6^{\circ} \mathrm{C}$ ). In general, higher temperatures yielded higher prevalence of infection. Nevertheless, high temperatures also boosted the antibody response leading to lower intensity of infection. In any case, with long times of exposure and high fish density, temperature (at the tested ranges) is not the determining factor, as evidenced by the same prevalence of infection in R1 groups in both trials. Consequently, at moderate water temperature, other factors, such as time of exposure and fish density arose as relevant. For myxozoan infections, the main control measure is prevention, thus an effective diagnosis that allows the early removal of moribund or infected fish could dramatically change the scenario in a fish farm. Since E. leei infection in gilthead sea bream can be easily transmitted fish-to-fish without any intermediate, other abiotic variables such as water flow or sediment that would compromise the establishment of the parasite in the system (Arndt et al., 2002; Fontes et al., 2015; Hallet \& Bartholomew, 2008) could be new interesting topics to study in the future.

\section{ACKNOWLEDGEMENTS \& FUNDING}

The authors thank J. Monfort and L. Rodríguez for histological processing. This work has been carried out with financial support from the European Commission, Horizon 2020 Framework Programme H2020, Societal Challenges under grant agreement 634429 (ParaFishControl). This publication reflects only the authors' view, and the European Union cannot be held responsible for any use that may be made of the information contained therein. IE was contracted under APOSTD/2016/037 grant by the "Generalitat Valenciana," and MCP, under Consejo Superior de Investigaciones Científicas CSIC PIE project no. 201740 E013. 


\section{Bibliography}


Abd-Elfattah A., Fontes I., Kumar G., Soliman H., Hartikainen H., Okamura B., El-Matbouli M. (2014) Vertical transmission of Tetracapsuloides bryosalmonae (Myxozoa), the causative agent of salmonid proliferative kidney disease. Parasitology. 141:482-490.

Abram Q. H., Dixon B., Katzenback B. A. (2017) Impacts of low temperature on the teleost immune system. Biology. 6:39.

Arndt R. E., Wagner E. J., Cannon Q., Smith, M. (2002) Triactinomyxon production as related to rearing substrate and diel light cycle, in Bartholomew J. L., Wilson J. C. (Eds.) Whirling Disease: Reviews and Current Topics. American Fisheries Society Symposium 29, Maryland, USA. pp. 87-91.

Bartholomew J. L., Whipple M. J., Stevens D. G., Fryer J. L. (1997) The life cycle of Ceratomyxa shasta, a myxosporean parasite of salmonids, requires a freshwater polychaete as an alternate host. J Parasitol. 83:859-868.

Bjork S. J., Bartholomew J. L. (2009) Effects of Ceratomyxa shasta dose on a susceptible strain of rainbow trout and comparatively resistant Chinook and coho salmon. Dis Aquat Organ. 86:29-37.

Braden L. M., Rasmussen K. J., Purcell S. L., Ellis L., Mahony A., Cho S., Whyte S. K., Jones S. R. M., Fast M. D. (2018) Acquired protective immunity in Atlantic salmon Salmo salar against the myxozoan Kudoa thyrsites involves induction of MHII beta(+) CD83(+) antigen-presenting cells. Infect Immun. 7:363-377.

China M., Nakamura H., Hamakawa K., Tamaki E., Yokoyama H., Masuoka S., Ogawa K. (2014) Efficacy of high water temperature treatment of myxosporean emaciation disease caused by Enteromyxum leei (Myxozoa). Fish Pathol. 49:137-140.

Clifton-Hadley R. S., Bucke D., Richards R. H. (1984) Proliferative kidney disease of salmonid fish: A review. J Fish Dis. 7:14.

Colloca F., Cerasi S. (2019, November 13) Sparus aurata [Internet report]. Cultured aquatic species fact sheets (FAO, 2009). Retrieved from http://www.fao.org/tempref/FI/DOCUMENT/aquaculture/CulturedSpecies/file/ en/en giltheadseabr.htm

de Buron I., Hill-Spanik K. M., Haselden L., Atkinson S. D., Hallett S. L., Arnott S. A. (2017) Infection dynamics of Kudoa inornata (Cnidaria: Myxosporea) in spotted seatrout Cynoscion nebulosus (Teleostei: Sciaenidae). Dis Aquat Organ. 127:29-40.

Diamant A. (1997) Fish-to-fish transmission of a marine myxosporean. Dis Aquat Organ. 30:99-105.

Diamant A., Wajsbrot N. (1997) Experimental transmission of Myxidium leei in gilthead sea bream Sparus aurata. B Eur Assoc Fish Pat. 17:99-103.

Estensoro I., Redondo M. J., Álvarez-Pellitero P., Sitjà-Bobadilla A. (2010) Novel horizontal transmission route for Enteromyxum leei (Myxozoa) by anal intubation of gilthead sea bream Sparus aurata. Dis Aquat Organ. 92:51-58.

Eszterbauer E., Atkinson S., Diamant A., Morris D., El-Matbouli M., Hartikainen H. (2015) Myxozoan life cycles: practical approaches and insights, in: Okamura B., Gruhl A., Bartholomew J. (Eds.) Myxozoan Evolution, Ecology and Development. Springer International Publishing, Switzerland. pp. 175-198.

Feist S. W., Longshaw M., Canning E. U., Okamura B. (2001) Induction of proliferative kidney disease (PKD) in rainbow trout Oncorhynchus mykiss via the bryozoan Fredericella sultana infected with Tetracapsula bryosalmonae. Dis Aquat Organ. 45:61-68.

Flecknell P. (2002) Replacement, reduction and refinement. ALTEX. 19:73-78.

Fontes I., Hallett S., Mo T. (2015) Comparative epidemiology of myxozoan diseases, in: Okamura B., Gruhl A., Bartholomew J. (Eds.) Myxozoan Evolution, Ecology and Development. Springer International Publishing, Switzerland.pp. 317-341.

Golomazou E., Athanassopoulou F., Karagouni E., Tsagozis P., Tsantilas H., Vagianou S. (2006) Experimental transmission of Enteromyxum leei Diamant, Lom and Dyková, 1994 in sharpsnout sea bream, Diplodus puntazzo C. and the effect on some innate immune parameters. Aquaculture. 260:44-53.

Gupta A., Kaur H. (2017) A new pathogen, Myxobolus holzerae (Myxosporea: Myxozoa) causing severe gill disease 
in an Indian major carp Labeo rohita in a cold water wetland, Punjab (India). Microb Pathogenesis. 111:244-251.

Hallett S., Bartholomew J. L. (2008) Effects of water flow on the infection dynamics of Myxobolus cerebralis. Parasitology. 135:371-384.

Jones S., Long A. (2019) Host size influences prevalence and severity of Kudoa thyrsites (Cnidaria: Myxosporea) infection in Atlantic salmon Salmo salar. Dis Aquat Organ. 133:99-105.

Korytář T., Wiegertjes G. F., Zusková E., Tomanová A. L., Lisnerová M., Patra S., Sieranski V., Šíma R., Born-Torrijos A., Wentzel A. S., Blasco-Monleon S., Yanes-Roca C., Policar T., Holzer A. S. (2019) The kinetics of cellular and humoral immune responses of common carp to presporogonic development of the myxozoan Sphaerospora molnari. Parasite Vector. 12:208-208.

Le Morvan C., Troutaud D., Deschaux P. (1998) Differential effects of temperature on specific and nonspecific immune defences in fish. J Exp Biol. 201:165-168.

Markiw M. E., Wolf K. (1983) Myxosoma cerebralis (Myxozoa: Myxosporea) etiologic agent of salmonid whirling disease requires tubificid worm (Annelida: Oligochaeta) in its life cycle. J Protozool. 30:561-564.

Markiw M. E. (1989) Portals of entry for salmonid whirling disease in rainbow trout. Dis Aquat Organ. 6:7-10.

Muñoz P., Cuesta A., Athanassopoulou F., Golomazou H., Crespo S., Padrós F., Sitjà-Bobadilla A., Albiñana G., Esteban M. A., Álvarez-Pellitero P., Meseguer J. (2007) Sharpsnout sea bream (Diplodus puntazzo) humoral immune response against the parasite Enteromyxum leei (Myxozoa). Fish Shellfish Immunol. 23:636-645.

Palikova M., Papezikova I., Markova Z., Navratil S., Mares J., Mares L., Vojtek L., Hyrsl P., Jelinkova E., SchmidtPosthaus H. (2017) Proliferative kidney disease in rainbow trout (Oncorhynchus mykiss) under intensive breeding conditions: Pathogenesis and haematological and immune parameters. Vet Parasitol. 238:5-16.

Piazzon M. C., Galindo-Villegas J., Pereiro P., Estensoro I., Calduch-Giner J. A., Gómez-Casado E., Novoa B., Mulero V., Sitjà-Bobadilla A., Pérez-Sánchez J. (2016) Differential modulation of IgT and IgM upon parasitic, bacterial, viral, and dietary challenges in a perciform fish. Front Immunol. 7:637.

Piazzon M. C., Calduch-Giner J. A., Fouz B., Estensoro I., Simó-Mirabet P., Puyalto M., Karalazos V., Palenzuela O., Sitjà-Bobadilla A., Pérez-Sánchez J. (2017) Under control: how a dietary additive can restore the gut microbiome and proteomic profile, and improve disease resilience in a marine teleostean fish fed vegetable diets. Microbiome. 5:164.

Picard-Sánchez A., Estensoro I., Del Pozo R., Piazzon M.C., Palenzuela O., Sitjà-Bobadilla A. (2019) Acquired protective immune response in a fish-myxozoan model encompasses specific antibodies and inflammation resolution. Fish Shellfish Immunol. 90:349-362.

Ray R. A., Holt R. A., Bartholomew J. L. (2012) Relationship between temperature and Ceratomyxa shasta induced mortality in Klamath River salmonids. J Parasitol. 98:520-526.

Ray R. A., Bartholomew J. L. (2013) Estimation of transmission dynamics of the Ceratomyxa shasta actinospore to the salmonid host. Parasitology. 140:907-916.

Redondo M. J., Palenzuela O., Riaza A., Macías A., Álvarez-Pellitero P. (2002) Experimental transmission of Enteromyxum scophthalmi (Myxozoa), an enteric parasite of turbot Scophthalmus maximus. J Parasitol. 88:482-488.

Redondo M. J., Palenzuela O., Álvarez-Pellitero P. (2004) Studies on transmission and life cycle of Enteromyxum scophthalmi (Myxozoa), an enteric parasite of turbot Scophthalmus maximus. Folia Parasitol. 51:188-198.

Shin S. P., Sohn H. C., Jin C. N., Kang B. J., Lee J. (2018) Molecular diagnostics for verifying an etiological agent of emaciation disease in cultured olive flounder Paralichthys olivaceus in Korea. Aquaculture. 493:18-25.

Sitjà-Bobadilla A., Diamant A., Palenzuela O., Álvarez-Pellitero P. (2007) Effect of host factors and experimental conditions on the horizontal transmission of Enteromyxum leei (Myxozoa) to gilthead sea bream, Sparus aurata L., and European sea bass, Dicentrarchus labrax (L.). J Fish Dis. 30:243-250.

Sitjà-Bobadilla A., Palenzuela O. (2012) Enteromyxum Species, in: Woo P. T. K., Buchmann K. (Eds.) Fish Parasites: Pathology and Protection. CAB International, Oxfordshire, UK. pp. 163-176. 
Thompson J. B., Snekvik K. R., Vincent E. R. (2010) The Effects of Myxobolus cerebralis on apache and gila trout in laboratory exposures. J Aquat Anim Health. 22:87-91.

Tops S., Lockwood W., Okamura B. (2006) Temperature-driven proliferation of Tetracapsuloides bryosalmonae in bryozoan hosts portends salmonid declines. Dis Aquat Organ. 70:227-236.

Udey L. R., Fryer J. L., Pilcher K. S. (1975) Relation of water temperature to ceratomyxosis in rainbow trout (Salmo gairdneri) and coho salmon (Oncorhynchus kisutch). J Fish Res Board Can. 32:1545-1551.

Yanagida T., Sameshima M., Nasu H., Yokoyama H., Ogawa K. (2006) Temperature effects on the development of Enteromyxum spp. (Myxozoa) in experimentally infected tiger puffer, Takifugu rubripes (Temminck \& Schlegel). J Fish Dis. 29:561-567.

Yanagida T., Palenzuela O., Hirae T., Tanaka S., Yokoyama H., Ogawa K. (2008) Myxosporean emaciation disease of cultured red sea bream Pagrus major and spotted knifejaw Oplegnathus punctatus. Fish Pathol. 43:45-48.

Yasuda H., Ooyama T., Iwata K., Tun T., Yokoyama H., Ogawa K. (2002) Fish-to-fish transmission of Myxidium spp. (Myxozoa) in cultured tiger puffer suffering from emaciation disease. Fish Pathol. 37:29-33.

Yasuda H., Ooyama T., Nakamura A., Iwata K., Palenzuela O., Yokoyama H. (2005) Occurrence of the myxosporean emaciation disease caused by Enteromyxum leei in cultured Japanese flounder Paralichthys olivaceus. Fish Pathol. 40:175-180.

Yokoyama H. (2003) A Review: Gaps in our knowledge on Myxozoan parasites of fishes. Fish Pathol. 38:125-136.

Yokoyama H., Grabner D., Shirakashi S. (2012) Transmission biology of the Myxozoa, in: Carvalho E. D., Silva G., Silva R. J. (Eds.) Health and Environment in Aquaculture. IntechOpen, London, UK. pp. 1-42.

Zinkernagel R. M., Ehl S., Aichele P., Oehen S., Kündig T., Hengartner H. (1997) Antigen localization regulates immune responses in a dose and time dependent fashion: A geographical view of immune reactivity. Immunol Rev.156:199-209. 


\section{SUPPLEMENTARY MATERIAL}

Supplementary table 1. Detailed information of the two effluent challenges performed in the study.

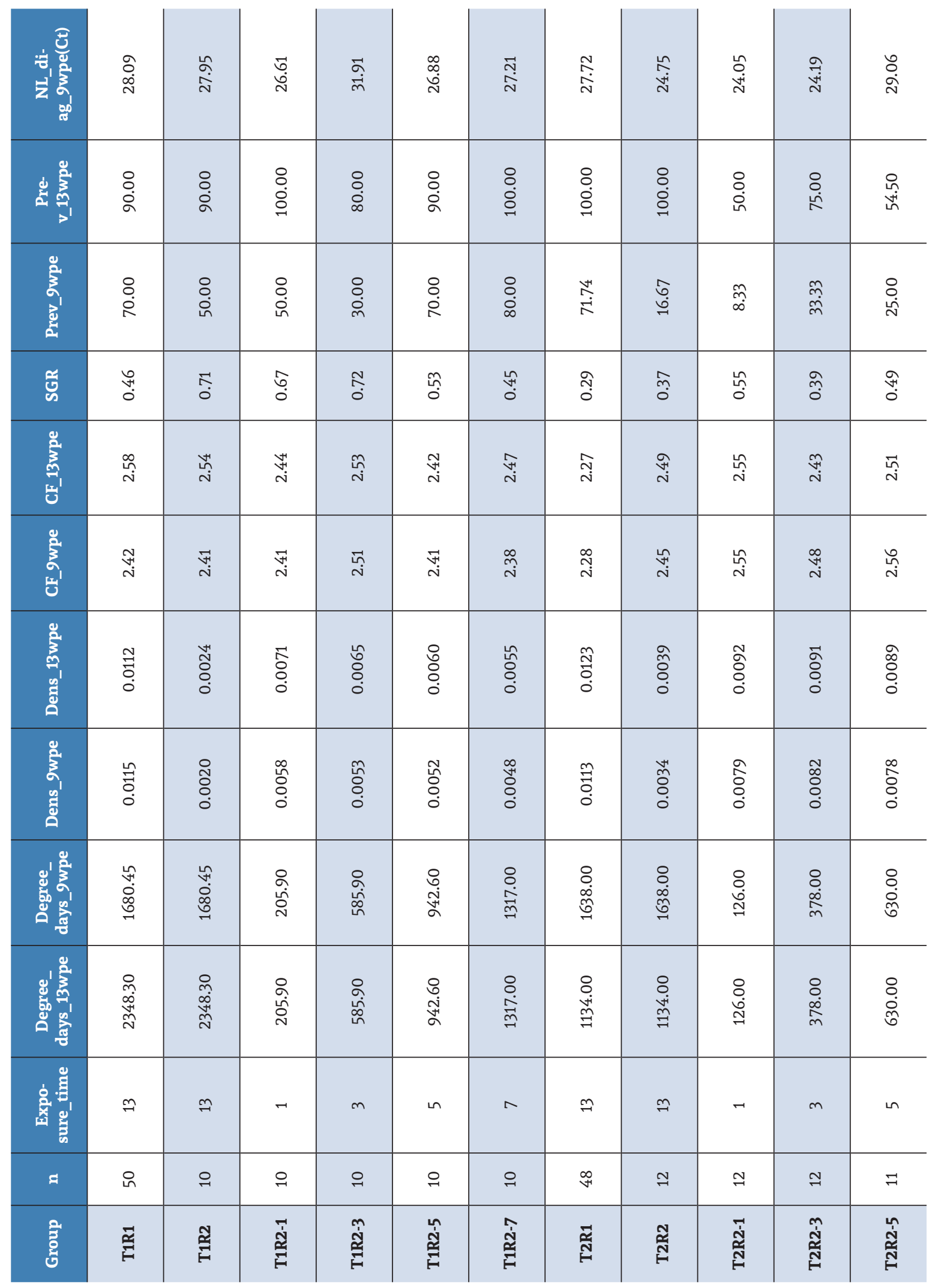




\begin{tabular}{|c|c|c|c|c|c|c|c|c|c|c|c|}
\hline 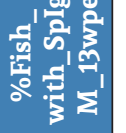 & $\begin{array}{l}\stackrel{\circ}{\circ} \\
\stackrel{2}{ }\end{array}$ & $\begin{array}{l}8 \\
\text { in } \\
\text { in }\end{array}$ & $\begin{array}{l}8 \\
8\end{array}$ & $\begin{array}{l}8 \\
\text { in }\end{array}$ & $\begin{array}{l}8 \\
\dot{0}\end{array}$ & $\begin{array}{l}8 \\
\dot{0}\end{array}$ & $\underset{\tilde{\infty}}{\tilde{\infty}}$ & $\begin{array}{l}\hat{\sigma} \\
\text { فे }\end{array}$ & 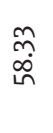 & $\begin{array}{l}8 \\
: \\
\circ\end{array}$ & ڤ̊̊ \\
\hline 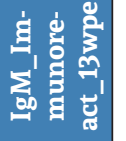 & & 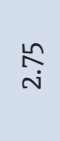 & $\stackrel{\hat{O}}{\mathrm{~m}}$ & $\underset{n}{\stackrel{P}{n}}$ & $\underset{\dot{m}}{\stackrel{\Omega}{m}}$ & 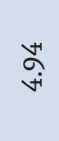 & : & $\begin{array}{l}\infty \\
\infty \\
0 \\
0\end{array}$ & $\underset{\substack{\infty \\
0}}{0}$ & $\stackrel{\widehat{\Im}}{\widehat{T}}$ & ڤn \\
\hline 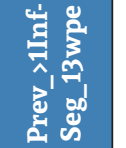 & $\begin{array}{l}\stackrel{8}{0} \\
\dot{\infty}\end{array}$ & $\begin{array}{l}8 \\
0 \\
\text { in }\end{array}$ & 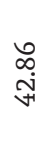 & $\stackrel{m}{m}$ & $\begin{array}{l}\hat{\mathrm{S}} \\
\text { فे }\end{array}$ & $\begin{array}{l}\hat{S} \\
\text { فे }\end{array}$ & $\begin{array}{l}8 \\
: \\
0\end{array}$ & 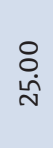 & $\begin{array}{l}\stackrel{\infty}{\sim} \\
\underset{\sim}{*}\end{array}$ & 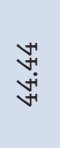 & $\begin{array}{l}\stackrel{0}{0} \\
\dot{\infty}\end{array}$ \\
\hline 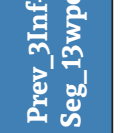 & : & $\begin{array}{l}\hat{S} \\
\text { ف․ }\end{array}$ & $\stackrel{\circ}{\circ}$ & $\stackrel{\circ}{\circ}$ & $\begin{array}{l}\hat{\sigma} \\
\text { فे }\end{array}$ & $\underset{m}{m}$ & $\begin{array}{l}\hat{0} \\
\text { bे }\end{array}$ & $\stackrel{\circ}{\circ}$ & $\stackrel{\circ}{\circ}$ & $\begin{array}{l}\underset{N}{N} \\
\text { Nat }\end{array}$ & $\begin{array}{l}8 \\
8\end{array}$ \\
\hline 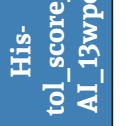 & 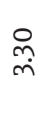 & 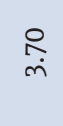 & $\underset{\tilde{N}}{\tilde{j}}$ & $\underset{i}{8}$ & $\underset{\sim}{\infty}$ & $\underset{\forall i}{\stackrel{n}{r}}$ & $\underset{\substack{\infty \\
+i}}{ }$ & $\stackrel{\tilde{n}}{\hat{N}}$ & $\underset{\text { i }}{\stackrel{\text { : }}{ }}$ & $\stackrel{\text { Mn }}{\text { Mn }}$ & 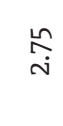 \\
\hline 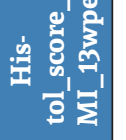 & 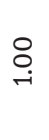 & ه্. & $\stackrel{8}{\circ}$ & $\stackrel{8}{\circ}$ & 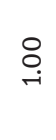 & 号 & $\stackrel{\stackrel{\sim}{N}}{\sim}$ & $\stackrel{0}{0}$ & $\stackrel{\circ}{\circ}$ & 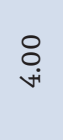 & $\underset{\tilde{m}}{m}$ \\
\hline 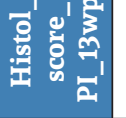 & 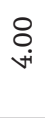 & 号 & 茫 & 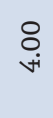 & $\stackrel{?}{r}$ & 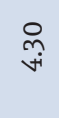 & $\begin{array}{l}\tilde{\infty} \\
\dot{n}\end{array}$ & $\underset{n}{\stackrel{m}{n}}$ & $\stackrel{\mathscr{n}}{\ddot{n}}$ & 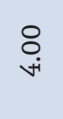 & 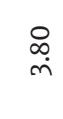 \\
\hline 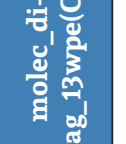 & 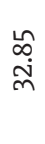 & $\begin{array}{l}\tilde{O} \\
\vec{m}\end{array}$ & 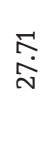 & $\begin{array}{l}\text { ָे } \\
\stackrel{\infty}{\infty}\end{array}$ & $\begin{array}{l}\tilde{o} \\
\dot{0} \\
\dot{m}\end{array}$ & $\begin{array}{l}\overrightarrow{i n} \\
\stackrel{i}{\hat{N}}\end{array}$ & $\begin{array}{l}\overrightarrow{\tilde{n}} \\
\text { กิ }\end{array}$ & $\stackrel{\infty}{\stackrel{\infty}{\sim}}$ & $\begin{array}{l}\stackrel{\stackrel{\omega}{0}}{\stackrel{m}{m}}\end{array}$ & $\begin{array}{l}\text { D } \\
\stackrel{\leftrightarrow}{N}\end{array}$ & 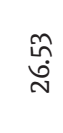 \\
\hline 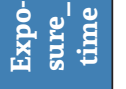 & 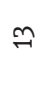 & 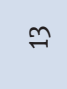 & - & $m$ & in & $n$ & $\eta$ & $\eta$ & - & $n$ & in \\
\hline$\approx$ & in & 으 & 음 & 으 & 으 & 으 & $\stackrel{\infty}{+}$ & $\approx$ & $\approx$ & $\stackrel{\sim}{\sim}$ & $F$ \\
\hline है & $\stackrel{g}{\stackrel{H}{F}}$ & $\underset{\mathfrak{z}}{\mathfrak{z}}$ & گ્ & 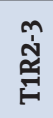 & 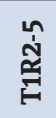 & 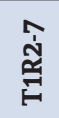 & $\overline{\stackrel{\widetilde{N}}{N}}$ & $\underset{\mathbb{N}}{\stackrel{\sim}{*}}$ & $\begin{array}{l}\overrightarrow{\tilde{\Xi}} \\
\stackrel{\tilde{N}}{*}\end{array}$ & 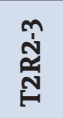 & 莡 \\
\hline
\end{tabular}

Exposure time: in weeks post-exposure (wpe); Dens: Density in Kg/L; CF: Condition factor; SGR: Specific growth rate for the period between intermediate and final sampling; Prev: Prevalence of infection (\% of infected fish); NL diag: non-lethal molecular diagnostic in Ct values

molec_diag: lethal molecular diagnostic in Ct values; Histol_score: mean histological score (range 0 - 6) of infected fish in anterior (AI), middle (MI) and posterior (PI) intestine; Prev_3InfSeg: percentage of fish with the 3 intestinal segments parasitized; Prev_>1InfSeg: percentage of fish with more than one intestinal segment parasitized; IgM_Immunoreact: IgM immunoreactivity. Mean intensity (range 0 - 6) for the presence of parasite specific antibodies (IgM) among fish with specific antibodies; \%Fish_with_SpIgM: percentage of fish with parasite specific antibodies (IgM). 
142 


\section{Chapter 3}

Passive immunization delays disease outcome in gilthead sea bream infected with Enteromyxum leei (Myxozoa), despite the moderate changes in IgM and IgT repertoire

Amparo Picard-Sánchez1; Itziar Estensoro¹; Pedro Perdiguero²; Raquel Del Pozo; Carolina Tafalla²; M. Carla Piazzonn'; Ariadna Sitjà-Bobadilla1 ${ }^{1}$

${ }^{1}$ Fish Pathology Group, Institute of Aquaculture Torre de la Sal (IATS-CSIC), Castellón, Spain;

${ }^{2}$ Centro de Investigación en

Sanidad Animal (INIA), Madrid, Spain

(Front Immunol. 11:581361, 2020) 
Control of enteric parasitic diseases of farmed gilthead sea bream 


\subsection{ABSTRACT}

Passive immunization constitutes an emerging field of interest in aquaculture, particularly with the restrictions for antibiotic use. Enteromyxum leei is a myxozoan intestinal parasite that invades the paracellular space of the intestinal epithelium, producing a slow-progressing disease, leading to anorexia, cachexia and mortalities. We have previously demonstrated that gilthead sea bream (Sparus aurata) that survive E. leei infection become resistant upon re-exposure, and this resistance is directly related to the presence of high levels of specific IgM in serum. Thus, the current work was aimed to determine if passive immunization could help to prevent enteromyxosis in gilthead sea bream and to study in detail the nature of these protective antibodies. Serum from a pool of resistant (SUR) or naïve (NAI) animals was intracoelomically injected $24 \mathrm{~h}$ prior to the E. leei-effluent challenge and at 9 days post-challenge (dpc). Effluent challenge lasted for 23 days, and then the injected groups were allocated in separate tanks with clean water. A nonlethal parasite diagnosis was performed at $56 \mathrm{dpc}$. At the final sampling (100 dpc), blood, serum and tissues were collected for histology, molecular diagnosis and the detection of circulating antibodies. In parallel, we performed an immunoglobulin repertoire analysis of the fish generating SUR and NAI sera. The results showed that, fish injected with parasite-specific antibodies became infected with the parasite, but showed lower disease signs and intensity of infection than the other groups, indicating a later establishment of the parasite. Repertoire analysis revealed that $E$. leei induced a polyclonal expansion of diverse IgM and IgT subsets that could be in part an evasion strategy of the parasite. Nonetheless, gilthead sea bream was able to produce sufficient levels of parasite-specific antibodies to avoid re-infection of surviving animals and confer certain degree of protection upon passive transfer of antibodies. These results highlight the crucial role of specific antibody responses against $E$. leei and set the basis for the development of effective treatment or prophylactic methods for aquaculture.

\section{Keywords}

Sparus aurata, passive immunity, antibodies, intestinal parasite, immune response, immunoglobulin repertoire. 


\subsection{INTRODUCTION}

Pathogens are an important cause of economic losses in aquaculture, and the partial effectiveness of the available treatments increases the chances of drugresistant pathogens in fish and in the aquatic environment (Miller \& Harbottle, 2018). The therapeutic use of specific antibodies is an attractive alternative to provide immunity against pathogens. Opposite to chemicals and antibiotics, which have a broad-spectrum of action, antibodies constitute a very specific defence mechanism. Antibody mediated immunity can be active or passive. Active immunity depends on the production of specific antibodies (spAbs) after direct contact with the pathogen or antigen (vaccination or random encounter), it takes days/weeks to develop and results in the formation of immunological memory that can last for months or years. In passive immunity, spAbs obtained from a previously infected or immunized donor, are introduced in a naïve individual to confer resistance or to combat a specific pathogen. Passive immunity is faster, short-lived and does not involve memory (Baxter, 2007).

Passive immunization can be allogeneic or xenogeneic, if the origin of the transferred Abs is the same or different than the recipient species, respectively. This technique has been applied successfully in human medicine (Both et al., 2012). It has also been tested in fish-parasite models showing promising results. Allogeneic therapies have partially protected carp (Cyprinus carpio) against Trypanoplasma borreli (Wiegertjes et al., 1995), or tomato clownfish (Amphiprion frenatus) against Amyloodinium ocellatum (Cobb et al., 1998). However, passive immunization failed to protect in other fish-parasites models like rainbow trout (Oncorhynchus mykiss) against Gyrodactylus derjavini infection (Lindenstrom \& Buchmann, 2000). Of note, the first two experiments required repeated doses of serum to induce protection, whereas in the latter, only one dose was administered. Xenogeneic therapies have also been applied successfully. Mouse monoclonal antibodies against surface proteins of Ichthyophthirius multifiliis protected channel catfish (Ictalurus punctatus) against infection (Clark et al., 1996). Clearly, a key aspect for the success of the procedure is a deep knowledge about the host-parasite model, especially the time for parasite spreading in the host and the time that transferred antibodies remain in the circulation of the recipient animal (Rajan et al., 2017).

Teleost fish have three different immunoglobulin (Ig) isotypes: IgM, IgT/Z and IgD (Salinas et al., 2011). The basic structure of fish Igs is the same as that of mammals. The heavy chain is constituted of an isotype-specific constant domain (CH) and a variable domain $(\mathrm{VH})$ which, together with the variable domain of the light chain (VL), are responsible for the great diversity of antigen binding sites. Each V domain has three hyper variable regions termed complementarity-determining regions (CDR), which constitute the majority of the antigen binding sites of the 
Ig molecule. Different combinations of CDR in VL and $\mathrm{VH}$ are responsible for the amazing diversity in binding sites among the millions of antibodies in an individual (Mashoof \& Criscitiello, 2016). In fish, IgM is the highest expressed Ig in all organs and it is essential for immune protection against different pathogens upon different routes of infection (Makesh et al., 2015; Ryo et al., 2010; Tadiso et al., 2011; Tian et al., 2009; Zimmerman et al., 2011). IgM is highly abundant in fish serum with concentrations between 800 and 9,000 $\mu \mathrm{g} / \mathrm{ml}$ (Ye et al., 2013). The teleost specific isotype IgT is considered the most important Ig in mucosal surfaces, but is also found in serum at much lower concentrations than IgM, so its role in systemic responses should not be discarded (Castro et al., 2013, 2014; Hansen et al., 2005; Zhang et al., 2010). The role of IgD is still not well defined in mammals or fish, however, recent studies performed in fish have established that it is also secreted (Ramirez-Gomez et al., 2012) and might have a relevant role in some mucosal surfaces such as gills (Castro et al., 2014) or intestine (Perdiguero et al., 2019). Like mammals, fish can develop immunological memory. A secondary exposure to an antigen will induce faster and greater responses than primary response, with larger numbers of antigen-specific B cells originated from the expansion of the pool of memory B cells. Detailed repertoire analyses have helped to define fish Ig responses upon infections of different aetiology (Abos et al., 2018; Castro et al., 2013).

Enteromyxum leei is a myxozoan intestinal endoparasite, that can be transmitted from fish-to-fish and causes a slow progressing catarrhal enteritis in gilthead sea bream (Sparus aurata) (Diamant et al., 1994; Sitjà-Bobadilla \& Palenzuela, 2012). The parasite lives and divides in the paracellular space between enterocytes causing chronic infections with intestinal inflammation leading to dysfunctional absorption and anorexia, reflected in weight loss and decreased specific growth rate (SGR), condition factor (CF), and fat deposits in liver (Sitjà-Bobadilla \& Palenzuela, 2012). Currently, this parasite cannot be cultured in vitro and there are no preventive or curative measures against this disease. However, there is plenty of background knowledge on the host response against the parasite (Estensoro et al., 2012, 2014; Piazzon et al., 2018; Picard-Sánchez et al., 2019; Ronza et al., 2020; Sitjà-Bobadilla et al., 2019; Sitjà-Bobadilla \& Palenzuela, 2012). We have recently demonstrated that gilthead sea bream is able to develop acquired immunity against E. leei. Fish that survived an infection did not get re-infected upon re-exposure, even 16 months after the initial exposure, and this resistance was correlated with high levels of specific antibodies (IgM) in serum (Picard-Sánchez et al., 2019). Therefore, the aim of the present study was to demonstrate the protective role of specific antibodies against enteromyxosis in gilthead sea bream by passive immunization of naïve animals. We also aimed to characterize the type of Ig response produced by this parasite, analysing and comparing the Ig repertoire in naïve and resistant animals re-exposed to the parasite. The results obtained in this study provide novel 
information to understand the role of antibodies during the response of gilthead sea bream to enteromyxosis, and will lead us a step further towards developing successful vaccines and/or treatments against this economically important disease in aquaculture.

\subsection{MATERIALS AND METHODS}

\subsubsection{Fish stock and maintenance}

Specific-pathogen-free (SPF) and clinically healthy gilthead sea bream juveniles from a commercial fish farm, were kept in $5 \mu \mathrm{m}$-filtered and UV irradiated sea water (salinity $37.5 \mathrm{~g} / \mathrm{l}$ ) between $18^{\circ} \mathrm{C}$ and $21.8^{\circ} \mathrm{C}$, with the natural photoperiod at latitude $40^{\circ} 5^{\prime} \mathrm{N} ; 0^{\circ} 10^{\prime} \mathrm{E}$. The SPF status was confirmed by qPCR according to the protocol previously described (Picard-Sánchez et al., 2019). Fish were fed ad libitum once a day a commercial diet (BioMar, Palencia, Spain). All experimental protocols involving fish were approved by the Ethics and Animal Welfare Committee of IATS, CSIC and Generalitat Valenciana. They were carried out in a registered installation facility in accordance with the principles published in the European animal directive (2010/63/EU) and Spanish laws (Royal Decree RD53/2013) for the protection of animals used in scientific experiments. All efforts were made to minimize the suffering of animals.

\subsubsection{Fish serum and tissues samples}

Fish sera used for the passive immunization trial were obtained from a previous experimental infection (Picard-Sánchez et al., 2019). Briefly, gilthead sea bream that had survived and cleared an infection with E. leei were re-exposed to the parasite 9 months after the beginning of the first infection by exposure to parasite-infected water effluent. These fish showed to be resistant to re-infection (SUR) and tested negative for the presence of the parasite 61 and 86 days after the second exposure. Sera from the four fish that showed the highest levels of parasite-specific IgM (immunoreactivity $=6$, see below) were selected and pooled. SUR serum and tissue samples were obtained 86 days after the second exposure to the parasite. In parallel, sera from four naïve (NAI) fish from the same batch were tested to be negative for parasite-specific IgM and pooled to be used as a control. Before injection, the complement was heat-inactivated $\left(42^{\circ} \mathrm{C} 30\right.$ $\mathrm{min})$. From the same eight animals, RNA from the anterior intestine was extracted as previously described (Picard-Sánchez et al., 2019). The anterior intestine was chosen because it is the tissue where immunoglobulin gene expression was significantly increased upon re-exposure to the parasite in SUR animals (Picard-Sánchez et al., 2019). 


\subsubsection{Passive immunization trial}

Fifty naïve gilthead sea bream (25.5 g) were individually tagged with passive integrated transponders (PIT-tags) and kept together in the same tank during the first part of the trial involving serum injections and effluent challenge. One day before and nine days after the challenge, 20 fish per group were injected intracoelomically (i.c.) with $10 \mu \mathrm{l} / \mathrm{g}$ of NAI or SUR serum. The remaining 10 fish were injected with $10 \mu \mathrm{l} / \mathrm{g}$ of sterile PBS. In addition, 10 naïve fish from the same stock were kept separately, constituting the non-challenged control group. A preliminary trial was conducted to determine the duration of injected antibodies in the recipient fish blood circulation. For that purpose: $10 \mu \mathrm{l} / \mathrm{g}$ of rabbit serum (DAKO) were i.c. injected and rabbit Igs were detected by dot blot in serum as soon as 1 hour post-injection and remained in circulation at least 9 days (Supplementary Figure 1).

One day ( $24 \mathrm{~h}$ ) after the first injection, fish were challenged with E. leei by exposure to infected water effluent, mimicking one of the natural routes of infection in farmed fish (Diamant \& Wajsbrot, 1997). Briefly, the tank holding 50 fish, already injected with PBS, NAI or SUR serum, received water effluent from a donor tank holding 33 heavily E. leei-infected gilthead sea bream, as previously described (Sitjà-Bobadilla et al., 2007a). At 23 days post-challenge (dpc), fish were weighed and measured, and the different injected groups were moved in groups of 10 to individual tanks receiving clean water, ending the effluent challenge. Serum-injected fish ( $n=20$ for each type of serum) were moved to two replicate tanks $(n=10)$ for each group. The 23-day exposure was selected as the minimum time needed for all fish to be challenged with the parasite without exerting a too high infection pressure that will mask the results at the end of the trial (Picard-Sánchez et al., 2020). At 56 dpc, fish were non-lethally sampled to evaluate the progression of the infection and the final lethal sampling was performed at $100 \mathrm{dpc}$. A schematic representation of the trial and samplings can be found in Figure 1.

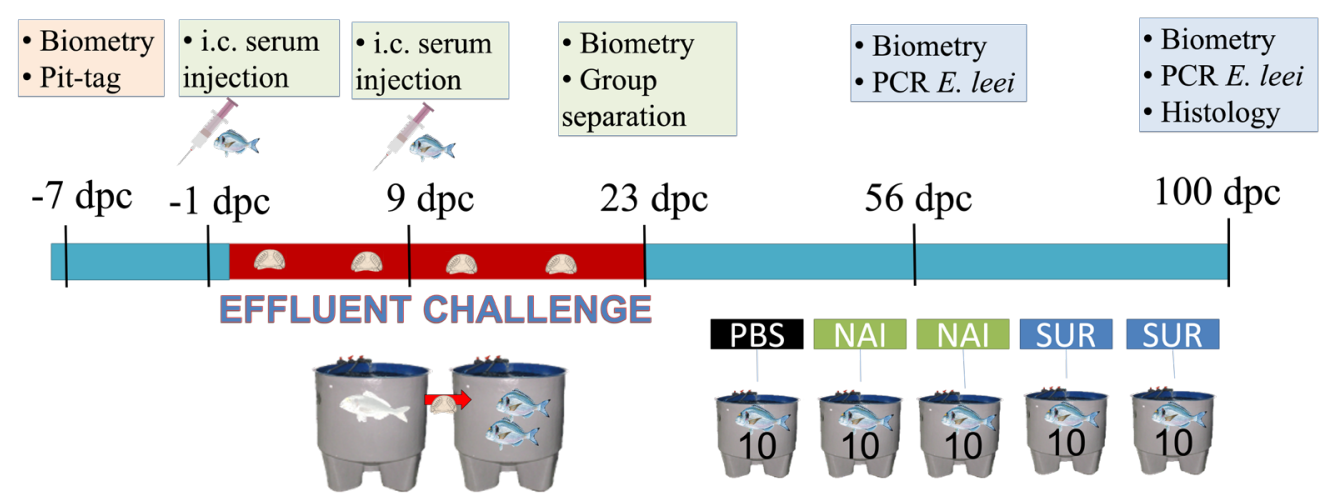

Figure 1. Schematic representation of the passive immunization of gilthead sea bream with Enteromyxum leei. Seven days before the challenge by effluent exposure, fish were tagged, weighted, measured and allocated together in the same tank. One day before the challenge and nine days post-challenge (dpc) fish were injected with the different sera or PBS. At 23 dpc, the effluent challenge was terminated and fish were separated in three different tanks (10 fish/ tank, SUR, NAI and PBS injected groups). At $56 \mathrm{dpc}$, a non-lethal diagnosis of the parasite by PCR was performed, and at $100 \mathrm{dpc}$ all fish were sacrificed and samples for histology and diagnosis were collected. i.c.: intracoelomic. 
Before all samplings (7 days before challenge, 23, 56 and $100 \mathrm{dpc}$ ), fish were starved for two days and biometric parameters measured. Additionally, at the second sampling (56 dpc), fish were also sampled for parasite diagnosis by non-lethal rectal probing and qPCR with specific primers for the parasite $18 \mathrm{~S}$ rRNA gene, as previously described (Picard-Sánchez et al., 2019). Finally, in the last sampling (100 dpc), fish were killed by overexposure to anaesthetic (MS-222, $0.1 \mathrm{~g} / \mathrm{l}$; Sigma), and blood and tissue samples for molecular and histological procedures were taken. Blood samples $(1 \mathrm{ml})$ were drawn from the caudal vessels by puncture with heparinized sterile needles and serum was obtained after overnight clotting at $4^{\circ} \mathrm{C}$ and centrifugation at $3,000 \times \mathrm{g}$ for $30 \mathrm{~min}$, and maintained at $-80^{\circ} \mathrm{C}$ until further use. Intestine (anterior-immediately after the pyloric caeca-, middle and posteriorimmediately before the anal ampoule), head kidney, spleen and liver samples from all fish were taken in $10 \%$ buffered formalin for standard histological procedures. Condition factor $\left(\mathrm{CF}=[100 \times\right.$ body weight $] /$ fork length $\left.{ }^{3}\right)$ and specific growth rate $(\mathrm{SGR}=[\ln ($ final weight $)-\ln ($ initial weight $) \times 100] /$ days $)$ were calculated for each animal individually. Infection intensity was semiquantitatively evaluated on Giemsa stained histological sections of anterior (AI), middle (MI) and posterior intestine (PI) using a scale from 1 (lowest) to 6 (highest) (Piazzon et al., 2018). The remaining intestinal tissue was processed for molecular diagnostic (qPCR), as previously described (Picard-Sánchez et al., 2019). In addition, PAS-staining was carried out on liver sections. One fish of the NAI group that died between the scheduled sampling points was checked post-mortem for the presence of the parasite and was no longer included in the results.

\subsubsection{Circulating antibody detection}

Total IgM and IgT were measured by ELISA as previously described (Piazzon et al., 2016). Specific IgM against E. leei in serum samples was immunohistochemically detected using paraffin embedded sections of $E$. leei-infected gilthead sea bream intestines obtained from previous and independent infection trials, following an immunohistochemical sandwich ELISA protocol, as described previously (PicardSánchez et al., 2019). Intensity of immunoreactivity of each fish serum against the parasite was evaluated by microscopic examination of the immunolabelled tissue sections according to a semiquantitative scale ranging from 0 to 6 (scaling: $0=$ no immunoreactivity against the parasite; 1 = very slight reactivity; $2=$ slight reactivity; 3 = medium reactivity; $4=$ medium-intense reactivity; $5=$ intense reactivity; 6 = very intense reactivity). 


\subsubsection{Immunohistochemistry}

The detection of $\mathrm{T}$ cells $\left(\mathrm{Zap} 70^{+}\right)$in the intestine of experimental individuals was performed by immunohistochemistry (IHC), as previously described (Piazzon et al., 2018). In the former study, we have reported that intestinal $T$ cells increase in numbers upon E. leei infection and these cells are one of the key mechanisms to clear the parasite. Briefly, paraffin sections ( $4 \mu \mathrm{m}$ thick) were deparaffinised, hydrated and the endogenous peroxidase activity was blocked by incubation in hydrogen peroxide ( $0.3 \%$ (v/v) for $30 \mathrm{~min}$ ). An antigen retrieval step was performed by boiling the samples in citrate buffer $\mathrm{pH} 6$ for $20 \mathrm{~min}$. Incubations were performed in a humid chamber at room temperature and all washing procedures consisted of successive 5 min immersions in TTBS (20 mM Tris-HCl, $0.5 \mathrm{M} \mathrm{NaCl}, 0.05 \%$ Tween 20, $\mathrm{pH} 7.2$ ) and TBS (20 mM Tris-HCl, $0.5 \mathrm{M} \mathrm{NaCl}, \mathrm{pH}$ 7.2). Slides were washed, blocked for $30 \mathrm{~min}$ with 1.5\% normal goat serum (VECTOR Laboratories). After washing, samples were then incubated with a monoclonal rabbit anti-Zap70 antibody (99F2 Cell Signaling Technologies) diluted 1:50 in TBS1\% BSA for $1 \mathrm{~h}$ and washed again. Slides were incubated with a biotinylated goat anti-rabbit antibody (VECTOR Labs.) diluted 1:200 in TBS 1.5\% normal goat serum for $1 \mathrm{~h}$, washed and the avidin-biotin-peroxidase complex (ABC) (VECTOR Labs.) was applied for $1 \mathrm{~h}$ before washing slides again. Bound peroxidase was developed by adding 3,3'-diaminobenzidine tetrahydrochloride chromogen (Sigma) for $2 \mathrm{~min}$ and the reaction was stopped with deionised water. Tissue sections were counterstained with Gill's haematoxylin, dehydrated and mounted with di-N-butyl phthalate in xylene. Incubation of tissue sections with $\mathrm{ABC}$ alone served as control to discard the presence of endogenous biotin-binding proteins. Negative controls omitting the primary antibodies, the secondary antibody and the $\mathrm{ABC}$ were carried out and were negative.

\subsubsection{Immunoglobulin repertoire amplification and sequencing}

To perform repertoire analysis of gilthead sea bream immunoglobulins, genomic regions potentially encoding IGHV genes were identified along gilthead sea bream draft genome (Pérez-Sánchez et al., 2019), searching for conserved domains using the online tool https://www.ncbi.nlm.nih.gov/Structure/cdd/wrpsb.cgi from NCBI. Transcriptional activity of identified regions were further confirmed by blasting against a gilthead sea bream transcriptome from a previous study (Piazzon et al., 2019). Nucleotide sequences were aligned using ClustalW (https://www.genome.jp/tools-bin/ clustalw) in order to identify conserved regions among genes to design primers which may amplify all potential genes. A total of 7 forward primers, recognizing the FR3 region, were designed and used in PCR amplifications in combination with reverse primers designed in IgM or IgT constant region ( $\mathrm{C} \mu 2$ and $\mathrm{C} T 1$, accession numbers KX599199 and KX599201, respectively) (Supplementary Table 1). 
To study the IgM and IgT repertoire in the fish used as serum donors for passive immunization, cDNA from anterior intestine of SUR and NAI donor fish were used as template in PCR amplifications for each primer combination (F+R). Mix of reagents for PCR reaction was: $1 \mu \mathrm{l}$ of cDNA as a template, $0.2 \mu \mathrm{M}$ of each forward and reverse primer combination, and $2.5 \mathrm{U} / \mu \mathrm{l}$ DNA polymerase (Accuprime Taq polymerase High Fidelity, Invitrogen) in $1 \times$ AccuPrime $^{\mathrm{TM}}$ PCR Buffer I, containing $2 \mathrm{mM} \mathrm{MgCl}_{2}$ and a mix of $0.2 \mathrm{mM}$ of each dNTP (Invitrogen). The thermal cycling regime was as follows: $94^{\circ} \mathrm{C}$ for $2 \mathrm{~min}$, followed by 40 cycles $\left(94^{\circ} \mathrm{C}\right.$ for $45 \mathrm{~s}, 55^{\circ} \mathrm{C}$ for $1 \mathrm{~min}$, and $72^{\circ} \mathrm{C}$ for $1 \mathrm{~min}$ ) and the final extension at $72^{\circ} \mathrm{C}$ for $10 \mathrm{~min}$. Negative controls without cDNA were also included.

For the visualization of PCR products, a $10 \mu \mathrm{l}$ aliquot from each PCR product was mixed with $2 \mu \mathrm{l}$ of loading buffer and loaded into a $1 \%$ agarose with ethidium bromide staining. At the same time, samples for sequencing were composed by 2 $\mu \mathrm{l}$ from each reaction belonging to the same individual pooled together. Samples were quality checked using an Agilent 2100 Bioanalyzer (Agilent Technologies) and sequenced by Life Sequencing (Valencia, Spain). One library per individual was constructed with the TruSeq DNA PCR-Free Library Prep Kit (Illumina, San Diego, CA, USA) according to the manufacturer's protocol. Libraries were pooled together, and paired-end sequencing was performed on an Illumina MiSeq with a MiSeq Reagent Kit v3 ( $\times 300$ cycles) cartridge (Illumina, San Diego, CA, USA).

\subsubsection{Sequence analysis}

Raw sequencing data were demultiplexed and sequencing adapters and barcodes were removed from the sequences using the MiSeq Analysis pipeline. The first 20 nucleotides from the reverse primers were used as a barcode for the identification of 3' ends corresponding to each constant Ig gene. Reads that matched a primer sequence with a maximum of three mismatches allowing an overlap of two nucleotides (--mismatches 3 --partial 2) were classified into the corresponding IgM or IgT isotype using the FASTQ/A Barcode splitter tool (http://hannonlab.cshl.edu/ fastx_toolkit/). The opposite paired end reads, corresponding to the 5' end of PCR products, were extracted with the FASTQ interlacer tool implemented in Galaxy (Blankenberg et al., 2010). The paired forward and reverse reads were merged using PEAR software (Zhang et al., 2014) with a minimum overlap size of 10 nucleotides. Finally, a quality filter was applied keeping sequences with a phred base quality 20 in at least the $90 \%$ of sequence.

In the current study, in absence of a V- D- J germline for our species, sequences for each isotype from the eight individuals were annotated by comparative genomics according the germline of zebrafish (Danio rerio), used as model species, which is 
available at International Immunogenetics information system databases (Lefranc et al., 2009). Thus, gilthead sea bream repertoire was annotated according the best match identified for each gene (V, D or J) from zebrafish using the IMGT/HighVQUEST tool (Alamyar et al., 2012). IMGT/HighV-QUEST results were parsed using convert tool from VDJtools software (Shugay et al., 2015). Non-functional clonotypes were filtered out using FilterNonFunctional tool from VDItools software. Retained functional clonotypes were further analysed using the repExplore, repClonality, repDiversity, geneUsage and getKmers tools from the $\mathrm{R}$ package immunarch (v0.5.5) (ImmunoMind Team, 2019). Prior to analysis, data were normalized by subsampling. This analysis allowed a first preliminary glimpse on the diversity of the clonotypes and the type of response that is being elicited by the parasite by comparison of two sampling groups (NAI vs. SUR).

\subsubsection{Statistical analysis}

Differences among groups were evaluated with one-way ANOVA followed by Tukey test. Data which failed the normality or equal variance test were analysed with Kruskal-Wallis ANOVA-I on ranks followed by Dunn's method. Differences between two groups were determined by Student's $t$ test or Mann-Whitney test when normality conditions were not met. A Chi-squared test was run to determine differences in the presence/absence of liver fat and glycogen deposits. In all cases differences were considered significant at $p<0.05$. Statistics and visualizations were performed with the R package immunarch (v0.5.5) (ImmunoMind) and GraphPad Prism (v6.01).

\subsection{RESULTS}

\subsubsection{Effects of passive immunization on clinical signs and infection parameters}

The typical clinical signs of enteromyxosis include weight loss and decreased condition factor (CF) and specific growth rate (SGR) (Sitjà-Bobadilla \& Palenzuela, 2012). The current results show that while CF of some challenged fish was not affected until the final sampling at $100 \mathrm{dpc}$, SGR was already affected at the intermediate sampling (56 dpc) in the PBS-injected group (Figure 2A-D). Fish injected with PBS or NAI serum always showed lower CF and SGR than non-challenged fish. Interestingly, fish injected with SUR serum did not show significant differences with the non-challenged controls and always displayed intermediate values.

No significant differences were found in the prevalence of infection among the different challenged groups in any of the sampling points. However, the prevalence of infection in fish injected with parasite-specific antibodies (SUR serum) was always the lowest (Figure 
2E). Histological diagnosis allowed assessing the percentage of fish with a progressed infection, that is, fish that have more than one intestinal segment parasitized. Progression of infection also showed lower values in fish injected with SUR serum (Figure 2E). Interestingly, all infected passively immunized fish (SUR serum) showed low intensity of infection (Ct values > 27), whereas, roughly half of the individuals from the other two groups had high intensity of infection (Ct values <27). The intensity of infection of SURinjected fish was significantly lower than that of the NAI serum group (Figure 2F, higher $\mathrm{Ct}$ values correspond to lower intensity of infection).

A

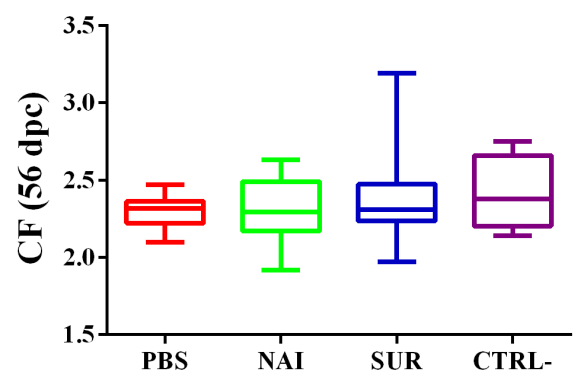

C

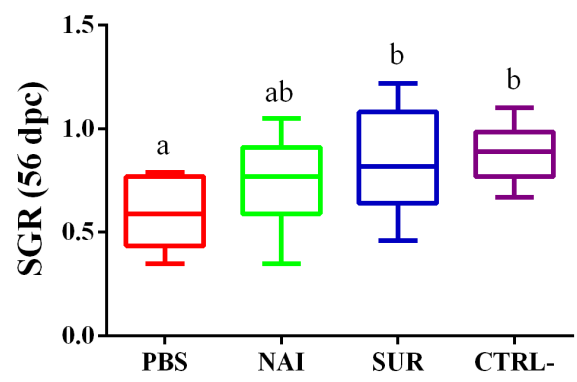

$\mathbf{E}$

\begin{tabular}{|l|l|l|l|}
\hline & PBS & NAI & SUR \\
\hline Prevalence $(56 \mathrm{dpc})$ & 20 & $\mathbf{3 0}$ & $\mathbf{1 5}$ \\
\hline Prevalence $(100 \mathrm{dpc})$ & $\mathbf{7 0}$ & $\mathbf{6 8 . 4}$ & $\mathbf{5 5}$ \\
\hline$\%$ fish $>1$ infected segment $(100 \mathrm{dpc})$ & $\mathbf{3 0}$ & $\mathbf{1 5 . 8}$ & $\mathbf{1 0}$ \\
\hline
\end{tabular}

B

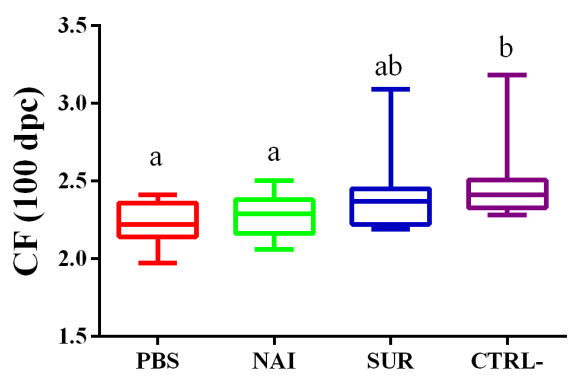

D

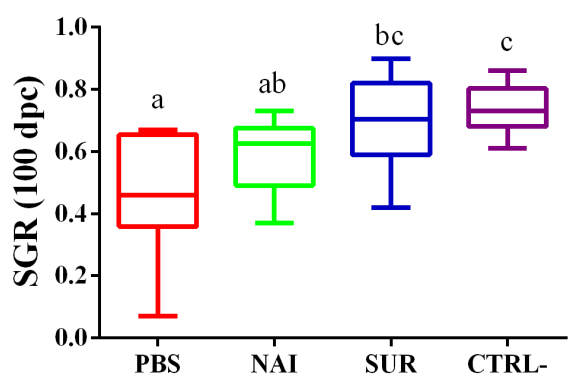

$\mathbf{F}$

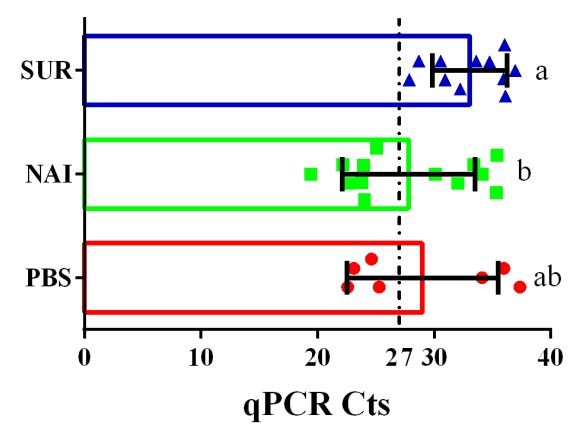

Figure 2. Disease signs of Enteromyxum leei in gilthead sea bream and parasite diagnosis. Condition factor (CF, A, B) and specific growth rate (SGR, C, D) were calculated for the intermediate (A, C) and final samplings (B, D). Prevalence of infection is represented as the percentage of infected fish at the intermediate and final samplings (56 and 100 days post-challenge, $\mathrm{dpc}$ ). The percentage of fish with more than one intestinal segment parasitized (\% fish > 1 infected segment) was calculated at the final sampling (E). Intensity of infection is shown as Ct values (mean $\pm \mathrm{SD}$ ) obtained from a parasite specific qPCR of the intestine at $100 \mathrm{dpc}(\mathrm{F})$. Low Ct values indicate high infection intensity. PBS is the group injected with PBS, whereas NAI represent the fish injected with serum without specific antibodies and SUR the fish injected with parasite-specific antibodies. The negative control (CTRL-) was the group not challenged with the parasite. Different letters indicate significant differences among groups $(p<0.05)$. 


\subsubsection{Effects of passive immunization on histopathology}

All parasite-challenged fish showed the typical intestinal reaction against E. leei, although some differences could be observed among groups. Overall, 70\%, 73.7\% and $85 \%$ of the PBS, NAI or SUR fish, respectively, had abundant lymphocyte-like cells at the base of the intestinal epithelium, particularly at the anterior segment (Figure 3A). IHC revealed that most of these cells were Zap70', identifying, at least part of this increased cell population, as T cells (Figure 3C, D). All challenged groups showed a noteworthy infiltration of eosinophilic granular cells in the epithelial layer (Figure 3B). Interestingly, the prototypical hyperplasia of the submucosa upon E. leei infection was observed in fewer animals injected with parasite-specific antibodies (35\% in SUR vs. 59\% in NAI) (Figure 3E, F). The most striking difference was found in the liver. The liver of heavily infected fish, due to the anorexia and the nutrient absorption impairment induced by the parasite, had clearly less accumulation of fat and glycogen deposits. This was the case for most PBS (80\%) and NAI (42\%) challenged fish, whereas all SUR challenged fish, except one (5\%), had normal liver histological features with abundant fat and glycogen deposits (Figure 3G, H, I, J). This difference was statistically significant (Chi-squared test, $p=0.02)$. 

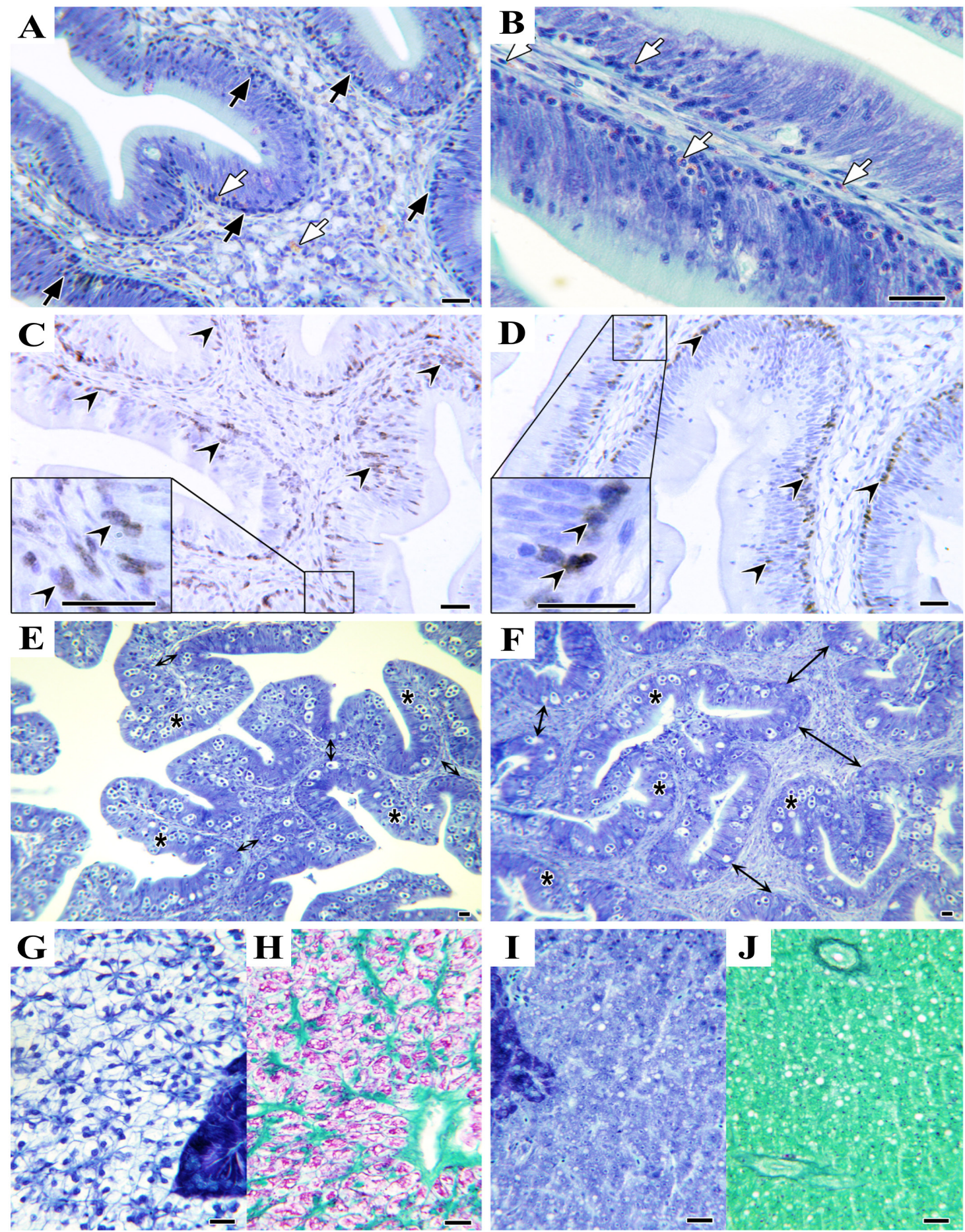

Figure 3. Histopathology. Microphotographs of gilthead sea bream tissue sections stained with Giemsa (A, B, E, F, G, I), PAS (H, J) or immunolabelled with anti-Zap70 (C, D). Anterior intestinal sections of SUR-sera injected fish at 100 days post challenge (A, B). Note the abundance of lymphocyte-like cells at the epithelial base and infiltrating the enterocyte layer (black arrows) and the abundant eosinophilic granular cells (white arrows). Zap70 ${ }^{+} \mathrm{T}$ cells at the anterior intestine of SUR-injected (C) and NAI-injected fish (D) (black arrowheads). Posterior intestine of SUR-injected (E) and NAI-injected fish (F) showing increased hyperplasia of the submucosa at the latter (double-headed arrows). Infected epithelia with Enteromyxum leei stages are indicated by asterisks. Comparative liver sections of SUR-injected (G, H) and NAI-injected fish (I, J). Note the abnormal absence of fat (colorless) and glycogen (purple) deposits in the hepatocytes shown in I and J. Scale bars $=20$ $\mu \mathrm{m}$. 


\subsubsection{Effects of passive immunization on circulating antibodies}

Total serum IgM, IgT and parasite specific IgM of the different groups were measured at $100 \mathrm{dpc}$. Total circulating IgM was significantly higher in the group injected with serum with parasite-specific antibodies than that of all the other groups, which did not show differences among them (Figure 4A). Circulating IgT was higher in the PBS injected group than in the control non-challenged group. The serum injected groups showed intermediate values (Figure 4B). No parasitespecific IgM was found in the non-challenged group, while all the other groups showed no differences among each other (Figure 4C).

A
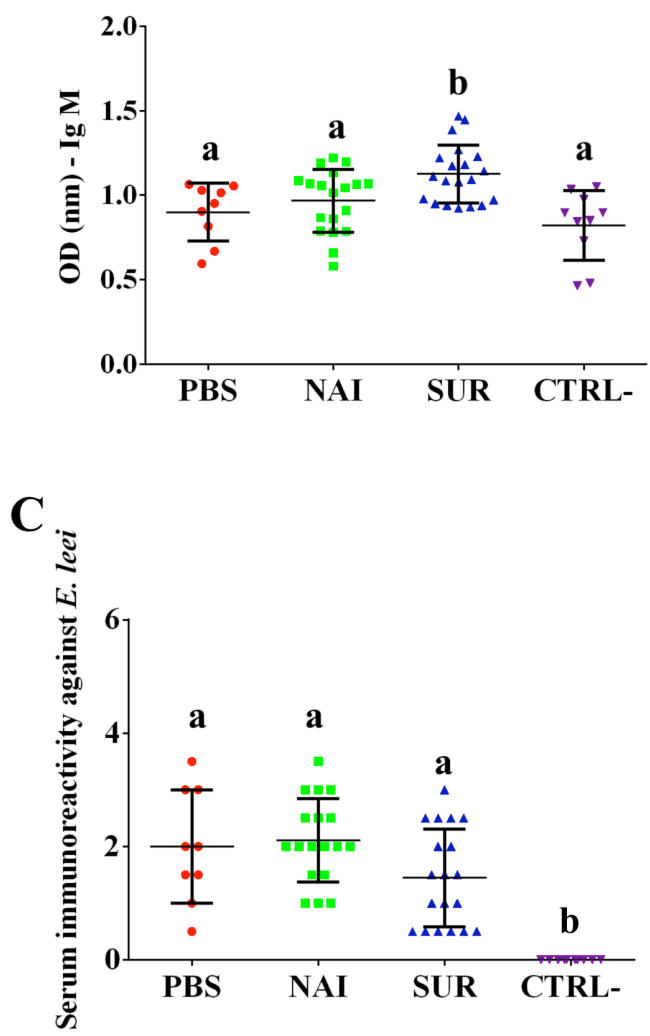

B

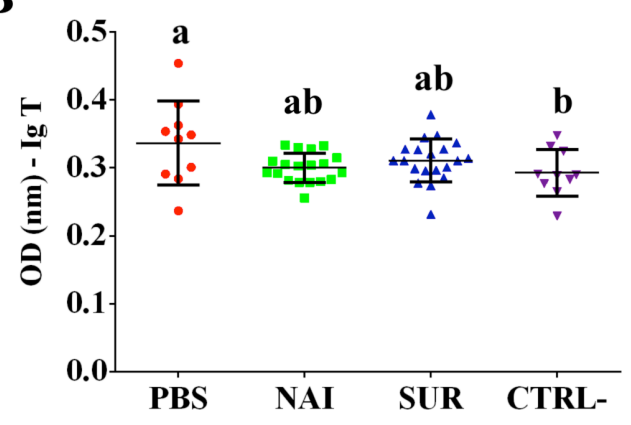

Figure 4. Circulating antibodies of gilthead sea bream in Enteromyxum leei infection. Total IgM (A), IgT (B) and parasite-specific IgM (C) in fish injected with PBS, or with serum without (NAI) or with (SUR) parasite-specific antibodies. The negative control (CTRL-) were fish not challenged with the parasite. Different letters indicate significant differences among groups $(p<0.05)$. 


\subsubsection{Immunoglobulin repertoire analysis}

The next step we took was an attempt to characterize the type of Ig response elicited by the parasite. Thus, we studied the IgM and IgT repertoire in the gilthead sea bream that acted as SUR and NAI serum donors for the passive immunization trial. By in silico analysis using immunoglobulin conserved domains, up to 46 regions showing homology with $\mathrm{V}$ genes were identified along the gilthead sea bream genome (Supplementary Data 1). Following this identification, 7 forward primers were designed in $\mathrm{V}$ regions which in combination with reverse primers located in IgM or IgT constant regions allowed for the first time the amplification of a global gilthead sea bream repertoire (Supplementary Figure 2). Using Illumina MiSeq (2 $\times 300$ ), an average of 2.2 million paired end reads per sample were obtained and assembled. Using the isotype specific primers as a barcode, $72.4 \%$ and $15.9 \%$ of the sequences were catalogued as IgM and IgT, respectively. Due to the absence of gilthead sea bream reference sequences for VDI genes, IMGT/HighV-QUEST analysis was performed using zebrafish as a reference. This analysis resulted in the identification of productive sequences as well as their CDR3, and served to assign VDJ genes and unique clonotypes according to homology to zebrafish, which allowed the comparison between experimental groups. 
A

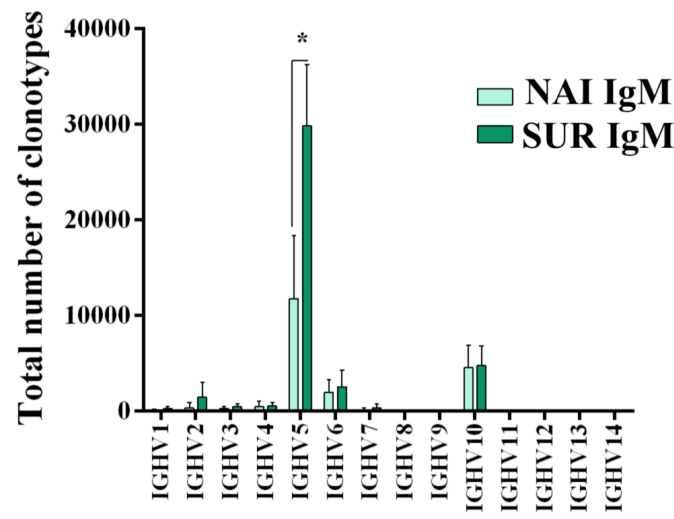

C

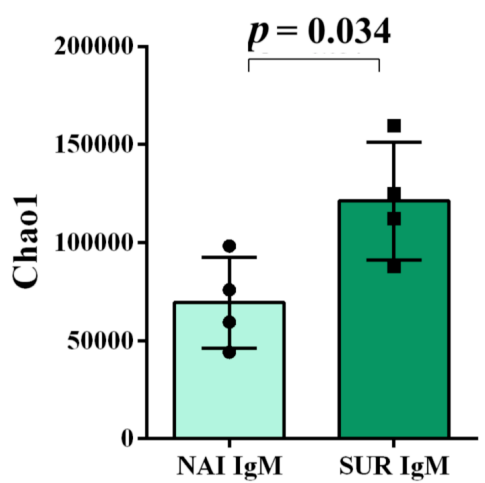

$\mathbf{E}$

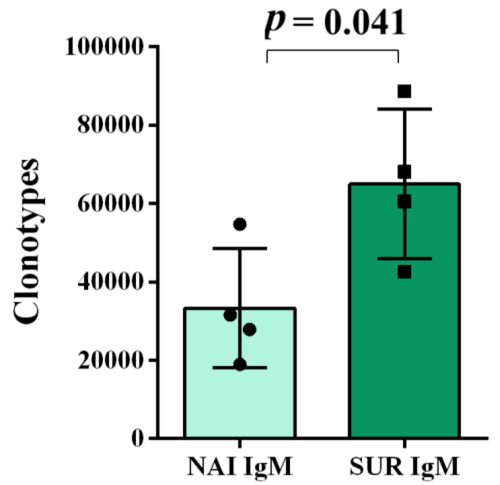

B

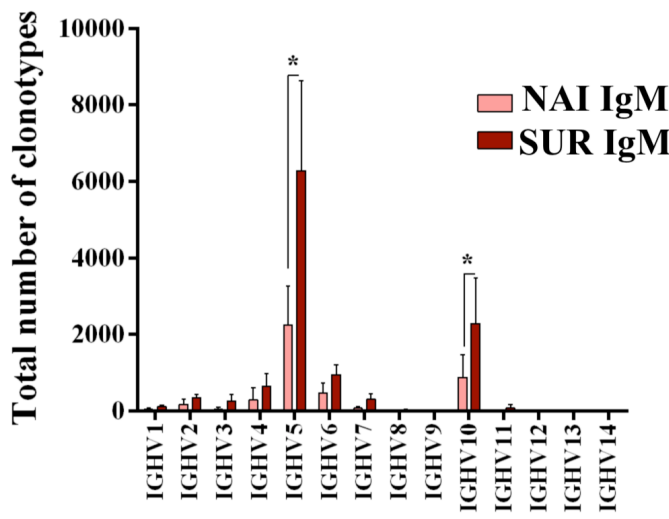

D

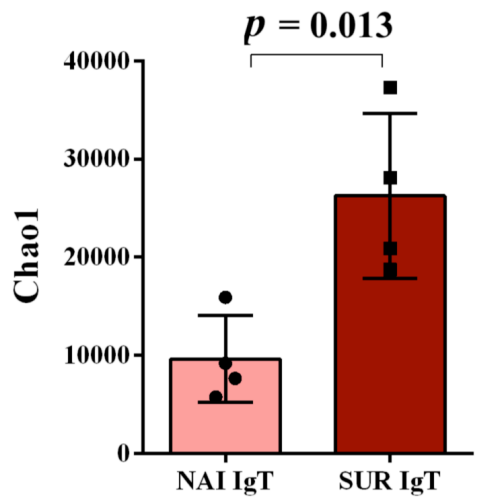

$\mathbf{F}$

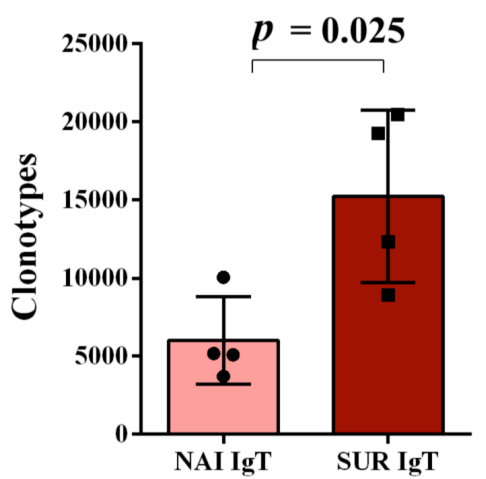

Figure 5. Clonotype diversity and V family usage. NAI fish did not have parasite-specific IgM in serum, whereas SUR fish had survived an infection with Enteromyxum leei and had high levels of circulating parasite specific IgM. The differential usage of VH-gene families for IgM (A) and IgT (B) was calculated with the assignment against zebrafish sequences. The diversity of the clonotypes sequenced for IgM (C) and IgT (D) was also evaluated using the Chao1 diversity index. Number of unique IgM (E) and IgT (F) clonotypes detected in the anterior intestine of the fish that acted as serum donors in the passive immunization trial. Bars represent the average number (mean $\pm \mathrm{SD}$ ) on unique sequences for $\mathrm{n}=4$ fish. Asterisks represent statistical differences between NAI and SUR groups at $p<0.05$. 
After analysis, $93.2 \%$ of the IgM sequences and $84.7 \%$ of the IgT sequences were classified as productive (Supplementary Table 2). Analysis with immunarch revealed that the number of unique clonotypes was significantly higher for both isotypes in immunized (SUR) fish than in naïve (NAI) individuals (Figure 5E, F). The clonotype diversity (estimated with the Chao1 index) was also always significantly higher in SUR animals than in NAI fish (Figure 5C, D). Sequences classified as similar to IGHV 5 and IGHV10 zebrafish subgroups were the most expressed in both isotypes. IGHV10 like sequences were significantly overexpressed in IgT, whereas IGHV5 like sequences were overrepresented in both isotypes in SUR fish (Figure $5 \mathrm{~A}, \mathrm{~B})$.
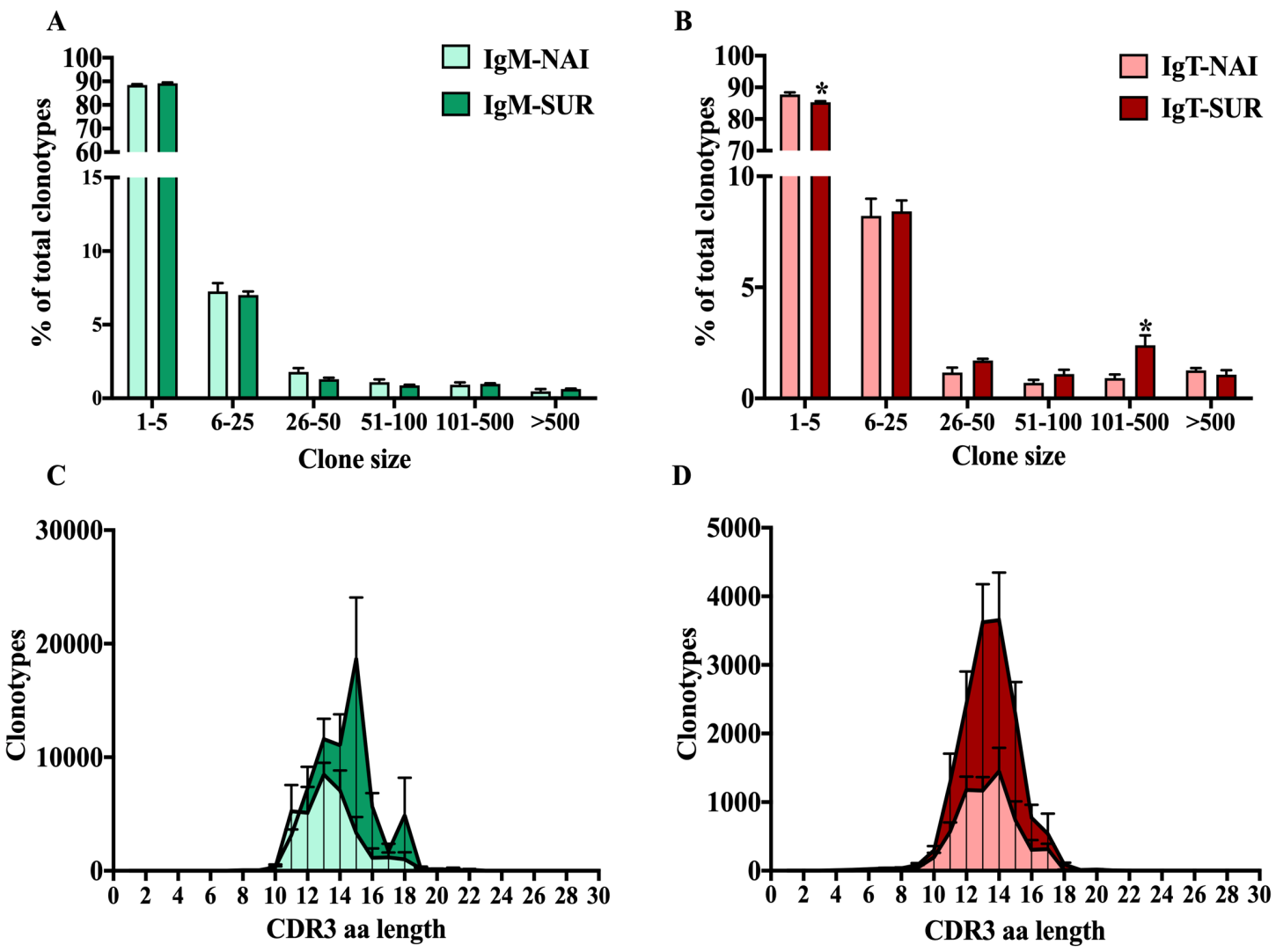

Figure 6. Clonal size distribution of $\operatorname{IgM}(\mathrm{A})$ and $\operatorname{IgT}(\mathrm{B})$ clonotypes in naïve (NAI, $\mathrm{n}=4$ ) fish and fish that acquired resistance to Enteromyxum leei (SUR, $\mathrm{n}=4$ ). Bars show the average percentage (mean $+\mathrm{SD})$ of clonotypes observed $\mathrm{n}$ times in the datasets. Asterisks represent statistical differences between NAI and SUR groups at $p<0.05$. CDR3 length distributions for all detected $\operatorname{IgM}(\mathrm{C})$ and $\operatorname{IgT}(\mathrm{D})$ clonotypes. The graphs represent the average number of clonotypes of a given amino acid (aa) length (+ SD) for SUR and NAI fish. Kolmogorov-Smirnoff tests reported that none of the curves followed a bell-shaped Gaussian distribution $(p>0.05)$. 
Around $90 \%$ (IgM) and $85 \%$ (IgT) of the different clonotypes were found one to five times, indicating a broad diversity of Ig repertoire in gilthead sea bream intestines. Interestingly, the percentage of IgT clonotypes found one to five times decreased in SUR animals, whereas IgT clonotypes, which were represented more than 100 times, increased in SUR fish. These results demonstrate a higher frequency of expanded IgT clonotypes in SUR fish, indicating a clear response. No significant changes were found for IgM (Figure 6A, B). When analysing the CDR3 amino acids length of the different clonotypes, a shift to longer CDR3 lengths was observed for IgM, but no clear differences appeared in IgT distribution (Figure 6C, D). None of the CDR3 length histograms fitted the expected Gaussian bell distribution normally expected for naïve animals (Kolmogorov-Smirnov normality test $p>0.05$ ). Analysis of the five most frequent $k$-mers $(k=5)$ from the CDR3 sequences revealed that the $\mathrm{k}$-mer YFDYW is very frequent in both, IgM and IgT sequences, with a frequency increase in SUR individuals. The other detected k-mers were not common for both isotypes (Figure 7).
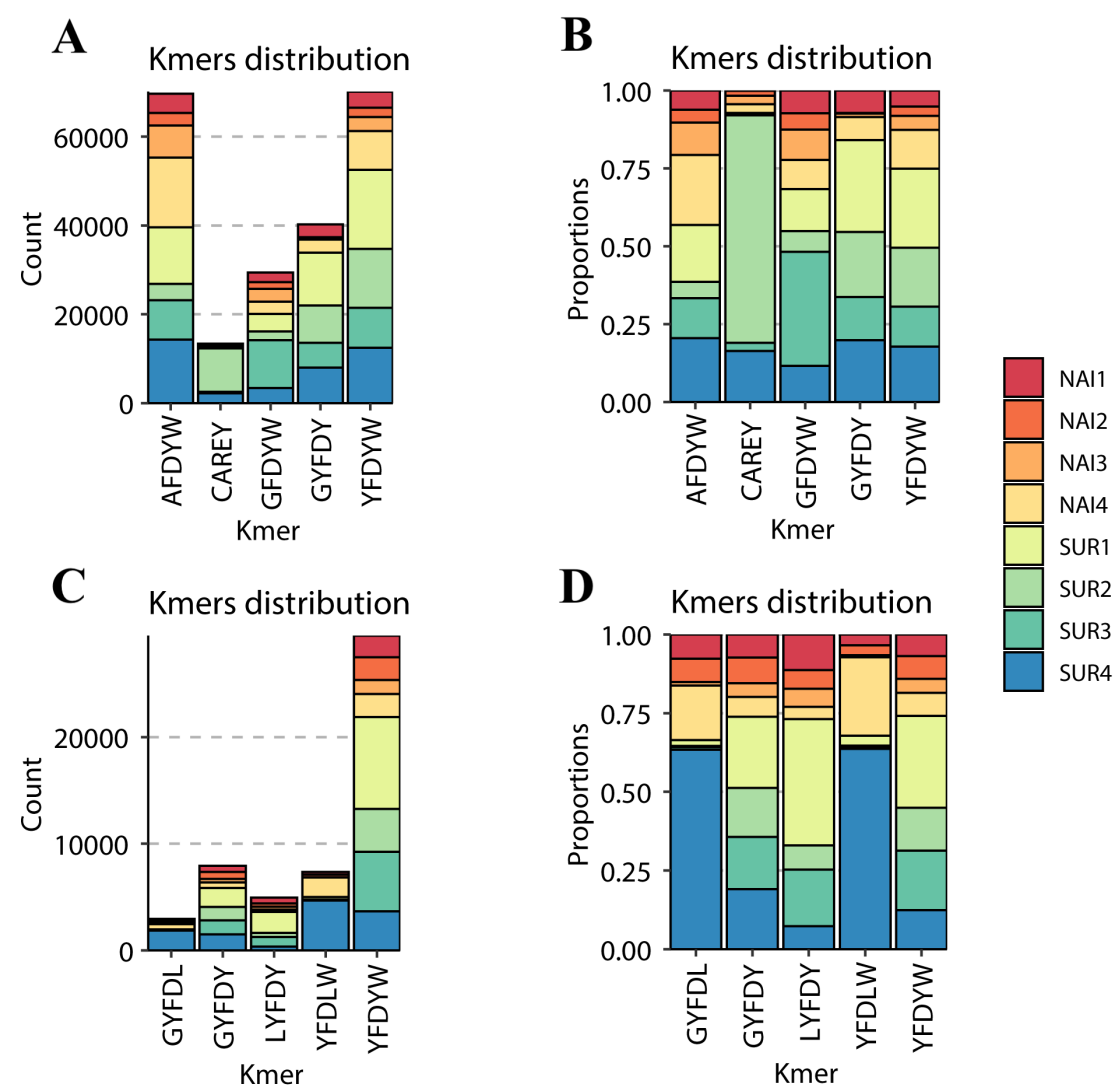

Figure 7. Graphical representation of the most abundant amino acid 5-mers in the CDR3 sequences of IgM (A, B) and IgT $(C, D)$. For each of the naïve $(\mathrm{NAI}, \mathrm{n}=4)$ and parasite resistant $(\mathrm{SUR}, \mathrm{n}=4)$ fish. The total count $(\mathrm{A}$, C) and the relative proportion in the eight samples (B, D) of each of the most abundant 5-mers are represented. 


\subsection{DISCUSSION}

In mammals, passive immunization represents a prophylactic strategy when vaccination is not possible, such as in immunosuppressed or very young individuals. Also, in the case of certain cancers or emerging human diseases, when vaccines or treatments have not yet been developed (Alzoughool \& Alanagreh, 2020; Page et al., 2020). In fish, passive transfer of specific antibodies by injection has been successful against some infectious diseases, including parasites (Clark et al., 1996; Cobb et al., 1998; Wiegertjes et al., 1995). Opposite to other animal production sectors, aquaculture animals live in the aquatic environment, which hinders individual treatment approaches. Thus, passive immunization through injection is not the most feasible strategy for fish. However, research is nowadays being conducted on encapsulated antibodies to be delivered in-feed (Chettri et al., 2019), as it was previously described for pigs (Hedegaard et al., 2016). In any case, experimental injection trials, such as the one presented in this manuscript, allow to test whether spAbs could be effective for treating a particular infection and can serve as a base to develop future control strategies such as vaccination or in-feed approaches (Rajan et al., 2017).

In passive immunization trials two main considerations are important: the time of the injected antibodies to reach the bloodstream, and the half-life of these antibodies in circulation (Rajan et al., 2017), which will indicate the time-frame of protection. In salmonids, i.c. injected allogeneic IgM against vibriosis could be detected in serum 10 min post-injection and the uptake was complete after $8 \mathrm{~h}$. These antibodies remained protective for up to 60 days (Harrell et al., 1976; Voss \& Fryer et al., 1979). In carp, the half-life of allogeneic IgM was much shorter, 22.5 days (Overath et al., 1999). It is clear that the half-life of serum antibodies varies depending on the species, but teleost Igs are assumed to remain in circulation from 12 to 16 days still retaining the antigen binding efficiency (Salinas et al., 2011). In the current study, we performed a preliminary test that revealed that i.c. injected rabbit IgG could be detected in gilthead sea bream serum from $1 \mathrm{~h}$ to 9 days post-injection in high concentrations. However, IgG besides being xenogeneic, which could elicit a host response against the injected molecules, is also a monomer, so faster absorption times could be expected. In any case, these results, together with literature data, allowed us to plan the injection timings. Fish were challenged with the parasite 24 $\mathrm{h}$ after serum injection, which is a safe window to ensure complete uptake of the antibodies. A second injection was performed 9 days post-challenge to ensure that injected antibodies remained in circulation during the whole challenge period (23 days). 
The current passive immunization trial did not show significant protection of gilthead sea bream against $E$. leei. However, the results indicate that injection with parasite-specific antibodies delayed the initial propagation of the parasite in naïve gilthead sea bream. The group that received serum with parasite-specific antibodies (SUR) showed minor signs of infection, particularly in terms of specific growth rate (SGR) and intensity of infection than fish injected with serum without specific antibodies or PBS. E. leei invades and proliferates in the intestinal epithelium, causing anorexia, impaired nutrient absorption and weight loss, leading to emaciation (Sitjà-Bobadilla \& Palenzuela, 2012). Decreased CF and SGR have been linked to E. leei infection in several studies (Estensoro et al., 2011; Piazzon et al., 2017; Sitjà-Bobadilla \& Palenzuela, 2012). This effect was evident in the PBS and NAI-injected groups, showing a higher prevalence of infection. SUR-injected fish also were infected, reaching $55 \%$ of prevalence of infection $100 \mathrm{dpc}$. However, these animals showed less disease signs than the other two challenged groups, in coincidence with lower prevalence and progression of the infection. E. leei starts invading the posterior part of the intestine, slowly progressing to the anterior and finally to the middle segment of the intestine (Estensoro et al., 2010; Sitjà-Bobadilla \& Palenzuela, 2012). Hence, the number of intestinal segments parasitized serves as a measure of the progression of the infection and provides a hint of the time a fish has been parasitized. In fact, the number of intestinal segments parasitized was significantly correlated (negatively) with disease signs such as CF (Picard-Sánchez et al., 2020). In the same study, intensity of infection, measured as Ct values of the parasite $18 \mathrm{~S}$ rRNA, was significantly correlated with CF, SGR and extension of the infection. Lower Ct values indicate more copies of parasite $18 \mathrm{~S}$ rRNA and coincided with stronger disease signs and more intestinal segments parasitized (Picard-Sánchez et al., 2020). The current results are in agreement with this previous observation.

E. leei induces a massive hyperplasia of the intestinal lamina propria-submucosa due to recruitment and proliferation of heterogeneous leukocytes (Sitjà-Bobadilla et al., 2015). IgM $\mathrm{M}^{+}$cells massively proliferate in the submucosa and within the epithelium (Estensoro et al., 2012), whereas Zap70 $\mathrm{T}$ cells aggregate mainly at the base of the epithelium (Piazzon et al., 2018). This inflammatory response, together with enterocyte apoptosis and necrosis, hamper intestinal barrier integrity producing nutrient malabsorption and osmotic intestinal failure (Sitjà-Bobadilla et al., 2019). As expected, these signs were also observed in the current experiment, where challenged fish showed an inflammatory response in the submucosa with abundant Zap70 ${ }^{+} \mathrm{T}$ cells at the base of the epithelium and infiltrated in it. Nutrient absorption impairment was also reflected in the reduction of lipid and glycogen deposits in the liver, which were probably used as an energy source to compensate the low energy intake. Again, fish injected with parasite-specific antibodies, even though they were infected, showed lower signs when compared to the other groups, probably denoting a later onset of the disease. 
Antibodies have already been described as main actors in gilthead sea bream immune response against E. leei (Picard-Sánchez et al., 2019), and in other fishmyxozoan models (Furuta et al., 2005; Hedrick et al., 1999; Saulnier \& de Kinkelin, 1996; Sitjà-Bobadilla et al., 2004, 2007b). The presence of high levels of circulating parasite-specific IgM in GSB that survived an infection with E. leei has been linked to their resistance to re-infection (Picard-Sánchez et al., 2019). E. leei induces IgM and IgT gene expression both at local (intestine) and systemic levels (head kidney), with a much potent local effect. This increased gene expression has been correlated with increased serum levels of parasite-specific IgM (Picard-Sánchez et al., 2019; Sitjà-Bobadilla et al., 2019). Regretfully, no information is available on levels of parasite-specific IgT or whether these specific antibodies can be found in circulation, as IgT has been described as mainly a mucosal Ig (Zhang et al., 2010). $B$ cell responses against $E$. leei have been detected from 40 days post-challenge onwards (Estensoro et al., 2012, 2014; Piazzon et al., 2016; Picard-Sánchez et al., 2019), and this response is temperature dependent (Abram et al., 2017; PicardSánchez et al., 2020). Delayed B cell responses against myxozoan parasites have already been described, with specific antibodies being detectable only after 6-8 weeks (Sitjà-Bobadilla, 2008). In the current challenge, we do not observe major differences on circulating IgM and IgT among injected groups. Fish injected with specific-antibodies showed an increase in total IgM but this increase is not reflected as a parasite-specific response, therefore, this difference remains to be explained. As expected, all groups challenged with the parasite showed an increase in parasite-specific IgM in serum after 100 days. The overall low antibody response detected in the current experiment could be attributed to the low temperature as previously described (Picard-Sánchez et al., 2020).

The current results suggest that the injected antibodies may be acting at the initial steps of parasite invasion probably by blocking the parasite host-specific receptors (opsonisation) and/or promoting phagocyte activity (Kalenik et al., 2014; Leiro et al., 1996). However, probably due to the long-term nature of the infection, the injected antibodies were not enough against the parasite pressure. Similar results have been found in other fish slow-progressing parasites models. Passively immunized rainbow trout showed a lower, although not significant, abundance of the monogenean Gyrodactylus derjavini one month after infection (Lindenstrom et al., 2000). Also in rainbow trout, passive immunization against the microsporidian parasite Loma salmonae was not enough to protect the fish against infection, but delayed its arrival at the heart by one week (Sánchez-Martínez et al., 2008). In our experiment, fish were challenged with parasite containing effluent water for 23 days and then each group was separated to tanks with clean water to avoid excessive parasite pressure. Nonetheless, cohabitation is also an effective infection route for E. leei (Picard-Sánchez et al., 2020). Thus, even with one animal getting infected during the challenge phase, the disease can still be transmitted to the 
cohabitants at later time points, when passively transferred antibodies are no longer viable. Future experiments using repeated injections of serum throughout the whole period, injecting higher amounts of immune serum, and/or separating the fish individually after the challenge phase, will help to determine the exact degree of protection that can be acquired by passive immunization against $E$. leei.

The current results support the hypothesis from previous studies that a specific antibody response is key against enteromyxosis in gilthead sea bream (PicardSánchez et al., 2019). Thus, we further analysed the antibody response being elicited in the animals that acted as serum donors for the passive immunization trial. These animals had high levels of circulating parasite-specific IgM and were resistant to re-infection. The repertoire analysis was performed on the anterior intestine, as previous studies revealed that in this particular organ IgM and IgT transcript expression increased upon re-exposure to the parasite in resistant fish (Picard-Sánchez et al., 2019). The CDR3 of the VH domain was targeted because this region is the key determinant of specificity in antigen recognition in antibodies and the $\mathrm{T}$ cell receptor, whereas CDR1 and CDR2 sequences are much more crossreactive (Xu \& Davis, 2000).

A strong and specific response against a pathogen would induce a decrease in the clonotype diversity in favour of the expansion of a specific pathogen-specific subset. This phenomenon has been described in fish in some viral infections (Castro et al., 2013). Parasites, however, are much more complex organisms, in particular metazoans with different life stages like myxozoans. Parasites can harbour vast amounts of antigenic peptides and some even demonstrated specific strategies to avoid the host's antibody responses. For instance, some parasites are known to induce hypergammaglobulinemia, resulting in a polyclonal expansion with significantly increased antibody titres but a limited proportion of parasitespecific antibodies. This has been reported for human and fish protozoan parasites, such as Trypanosoma cruzi (Bermejo et al., 2011) or Trypanoplasma borreli (Saeij et al., 2003), but also in some myxozoan infections caused by Sphaerospora molnari (Korytář et al., 2019) or Tetracapsuloides bryosalmonae (Abos et al., 2018). The current results, showing a significant increase in clonotype diversity for both IgM and IgT, together with previous findings on this host-parasite model (Estensoro et al., 2012; Piazzon et al., 2016), seem to indicate a similar strategy for E. leei. Close to $90 \%$ of IgT and IgM clonotypes were found 1-5 times, indicating a high degree of repertoire diversity in gilthead sea bream anterior intestines. This high clonotype diversity, with very few clonotypes expressed more than 50 times, has been described in naïve rainbow trout spleen and, upon viral (Castro et al., 2013) or parasitic (Abos et al., 2018) infection, having certain clonotypes a high frequency, and indicating a clear response against the pathogens. The results of the current study deal with the Ig repertoire of intestinal B cells, thus the pattern 
is expected to be different from that found in spleen. Intestine is a major mucosal tissue that is in close contact with the environment and harbours a very diverse community of symbiont microorganisms, the microbiota. Hence, intestinal cells are constantly exposed to a myriad of antigens. This probably explains the different patterns found in naïve animals in our study with more abundant high frequency clonotypes and non-Gaussian CDR3 length distributions. The CDR3 length distribution analysis is an estimate of the overall diversity and deviations from a bell-shaped Gaussian distribution are indicative of clonal expansions (Miqueu et al., 2007). The different distribution of IgM CDR3 lengths, and the significantly more abundant IgT clonotypes with frequencies of 101-500 in SUR animals indicate that $E$. leei is inducing a clear response that involves both isotypes but probably through different mechanisms. A complete characterization of a gilthead sea bream specific reference germline throughout the definition of the gilthead sea bream IgH locus following the identification of all segments encoding V, D and I genes will allow further deep analyses of this response at gene level. Thus, the definition of a gilthead sea bream specific germline will allow a better dissection of clonotypes specifically selected during the response to myxozoans as well as will allow to further explore somatic hypermutation patterns in selected clonotypes.

To conclude, E. leei induces a differential IgM and IgT response in gilthead sea bream characterized by a polyclonal expansion of diverse Ig subsets. This could be part of an immune-evasion strategy elicited by the parasite aiming to dilute parasite-specific antibodies by increasing the proportion of irrelevant antibodies, as has been described in similar host-parasite models (Abos et al., 2018; Korytář et al., 2018). However, increased levels of parasite-specific antibodies (IgM) have been detected in the serum of gilthead sea bream when challenged with the parasite, and the presence of high levels of these antibodies has been related with acquired resistance. In addition, the current results show that passive transfer of parasitespecific antibodies can delay the establishment of the infection and the appearance of disease signs. Taken together, these findings indicate that, regardless of the probable immune-evasion strategy of the parasite, antibodies are key molecules against enteromyxosis in gilthead sea bream. Future studies should be conducted to further evaluate the role of specific IgT, a specialized mucosal immunoglobulin, in this model. Also, more in depth studies on the protective antibody response will be key to develop effective treatments and prophylactic methods against E. leei. 


\section{ACKNOWLEDGMENTS \& FUNDING}

The authors thank P. Boudinot (INRAE) for his help in designing and interpreting the immunoglobulin repertoire study and results, J. Pérez-Sánchez (IATS-CSIC) for providing access to the gilthead sea bream genome sequences to perform the repertoire analysis, and J. Monfort and L. Rodríguez (IATS-CSIC) for histological processing.

This work was funded by EU H2020 program through ParaFishControl Project (634429) and by the European Research Council (ERC Consolidator Grant 2016 725061 TEMUBLYM). This publication reflects only the authors' view and the European Union cannot be held responsible for any use that may be made of the information contained herein. MP was funded by a Ramón y Cajal Postdoctoral Research Fellowship (RYC2018-024049-I/AEI/10.13039/501100011033 \& ESF), IE under APOSTD/2016/037 grant by the "Generalitat Valenciana"and RP was contracted under the PTA-Program from the Spanish Ministry of Science, Innovation and Universities (PTA2018-015315-I). We acknowledge support of the publication fee by the CSIC Open Access Publication Support Initiative through its Unit of Information Resources forResearch (URICI).

\section{DATA AVAILABILITY STATEMENT}

The datasets generated for the study of gilthead sea bream IgM and IgT repertoire can be found in the Sequence Read Archive (SRA) of NCBI under the Bioproject accession number PRJNA644800 (BioSample accession numbers: SAMN15479954 - SAMN15479961). 
Bibliography 
Abos B., Estensoro I., Perdiguero P., Faber M., Hu Y. F., Rosales P. D., Granja A. G., Secombes C. J., Holland J. W., Tafalla C. (2018) Dysregulation of B cell activity during proliferative kidney disease in rainbow trout. Front Immunol. 9:1203.

Abram Q. H., Dixon B., Katzenback B. A. (2017) Impacts of low temperature on the teleost Immune System. Biology. 6:39.

Alamyar E., Duroux P., Lefranc M.P., Giudicelli V.(2012) IMGT® Tools for the nucleotide analysis of immunoglobulin (IG) and T cell receptor (TR) V-(D)-J repertoires, polymorphisms, and IG mutations: IMGT/V-QUEST and IMGT/ HighV-QUEST for NGS. Methods Mol Biol. 882:569-604.

Alzoughool F., Alanagreh L. (2020) Coronavirus drugs: Using plasma from recovered patients as a treatment for COVID-19. Int J Risk Saf Med. 31:47-51.

Baxter D. (2007) Active and passive immunity, vaccine types, excipients and licensing. Occup Med. 57:552-56.

Bermejo D. A., Amezcua-Vesely M. C., Khan M., Acosta-Rodríguez E. V., Montes C. L., Merino M. C., Toellner K. M., Mohr E., Taylor D., Cunningham A. F., Gruppi A. (2011) Trypanosoma cruzi infection induces a massive extrafollicular and follicular splenic B-cell response which is a high source of non-parasite-specific antibodies. Immunology. 132:123-133.

Blankenberg D., Gordon A., Von Kuster G., Coraor N., Taylor J., Nekrutenko A., Team G. (2010) Manipulation of FASTQ data with Galaxy. Bioinformatics. 26:1783-1785.

Both L., Banyard A. C., van Dolleweerd C., Horton D. L., Ma J. K. C, Fooks A. R. (2012) Passive immunity in the prevention of rabies. Lancet Infect Dis. 12:397-407.

Castro R., Jouneau L., Pham H. P., Bouchez O., Giudicelli V., Lefranc M. P., Quillet E., Benmansour A., Cazals F., Six A., Fillatreau S., Sunyer O., Boudinot P. (2013) Teleost fish mount complex clonal IgM and IgT responses in spleen upon systemic viral infection. PLoS Pathog. 9:e1003098.

Castro R., Abós B., Pignatelli J., Von Gersdorff-Jørgensen L., Granja A. G., Buchmann K., Tafalla C. (2014) Early immune responses in rainbow trout liver upon viral hemorrhagic septicemia virus (VHSV) infection. PLoS One. 9:1-13.

Chettri J. K., Al-Jubury A., Hansen M. B., Lihme A., Dalsgaard I., Buchmann K., Heegaard P. M. H. (2019) Protective effect of infeed specific IgM towards Yersinia ruckeri in rainbow trout. Fish Shellfish Immunol. 93:934-939.

Clark T. G., Lin T. L., Dickerson H. W. (1996) Surface antigen cross-linking triggers forced exit of a protozoan parasite from its host. Proc Natl Acad Sci U S A. 93:6825-6829.

Cobb C. S., Levy M. G., Noga E. J. (1998) Acquired immunity to amyloodiniosis is associated with an antibody response. Dis Aquat Organ. 34:125-133.

Diamant A., Lom J., Dyková I. (1994) Myxidium leei n. sp., a pathogenic myxosporean of cultured sea bream Sparus aurata. Dis Aquat Organ. 20:137-141.

Diamant A., Wajsbrot N. (1997) Experimental transmission of Myxidium leei in gilthead sea bream Sparus aurata. Bull Eur Assoc Fish Pathol. 17:99-103.

Estensoro I., Benedito-Palos L., Palenzuela O., Kaushik S., Sitjà-Bobadilla A., Pérez-Sánchez J. (2011) The nutritional background of the host alters the disease course in a fish-myxosporean system. Vet Parasitol. 175:141-150.

Estensoro I., Calduch-Giner J. A., Kaushik S., Pérez-Sánchez J., Sitjà-Bobadilla A. (2012) Modulation of the IgM gene expression and the IgM immunoreactive cell distribution by the nutritional background in gilthead sea bream (Sparus aurata) challenged with Enteromyxum leei (Myxozoa). Fish Shellfish Immunol. 33:401-410.

Estensoro I., Mulero I., Redondo M. J., Álvarez-Pellitero P., Mulero V., Sitjà-Bobadilla A. (2014) Modulation of leukocytic populations of gilthead sea bream (Sparus aurata) by the intestinal parasite Enteromyxum leei (Myxozoa: Myxosporea). Parasitology. 141:425-440.

Estensoro I., Redondo M. J., Álvarez-Pellitero P., Sitjà-Bobadilla A. (2010) Novel horizontal transmission route for Enteromyxum leei (Myxozoa) by anal intubation of gilthead sea bream Sparus aurata. Dis Aquat Organ 92:51-58. 
Furuta T., Ogawa K., Wakabayashi H. (2005) Humoral immune response of carp Cyprinus carpio to Myxobolus artus (Myxozoa: Myxobolidae) infection. J Fish Biol. 43:150-441.

Hansen J. D., Landis E. D., Phillips R. B. (2005) Discovery of a unique Ig heavy-chain isotype (IgT) in rainbow trout: Implications for a distinctive B cell developmental pathway in teleost fish. Proc Natl Acad Sci U S A.102:6919-6924.

Harrell L. W., Etlinger H. M., Hodgins H. O. (1976) Humoral factors important in resistance of salmonid fish to bacterial disease. II. Anti-Vibrio anguillarum activity in mucus and observations on complement. Aquaculture. 7:363-370.

Hedegaard C. J., Strube M. L., Hansen M. B., Lindved B. K., Lihme A., Boye M., Heegaard P. M. H. (2016) Natural pig plasma immunoglobulins have anti-bacterial effects: Potential for use as feed supplement for treatment of intestinal infections in pigs. PLoS One. 11:e0147373.

Hedrick R., El-Matbouli M., Adkison M., MacConnell E. (1999) Whirling disease: Re-emergence among wild trout. Immunol Rev. 166:365-376.

ImmunoMind Team. (2019) Immunarch: An R Package for Painless Bioinformatics Analysis of T-Cell and B-Cell Immune Repertoires. Zenodo.

Groberg W. J., Voss E., Fryer J. L. (1979) Metabolism of coho salmon Ig: Intraperitoneal absorption properties of coho salmon tetrameric Ig. Fish Pathol.13:189-196.

Kalenik B., Sawicka R., Góra-Sochacka A., Sirko A. (2014) Influenza prevention and treatment by passive immunization. Acta Biochim Pol. 61:573-587.

Korytář T., Wiegertjes G. F., Zusková E., Tomanová M. A. L., Patra S., Sieranski V., Šíma R., Born-Torrijos A., Wentzel A. S., Blasco-Monleon S., Yanes-Roca C., Policar T., Holzer A. S. (2019) The kinetics of cellular and humoral immune responses of common carp to presporogonic development of the myxozoan Sphaerospora molnari. Parasit Vectors. 12:208.

Lefranc M. P., Giudicelli V., Ginestoux C., Jabado-Michaloud J., Folch G., Bellahcene F., Wu Y., Gemrot E., Brochet X., Lane J., Regnier L., Ehrenmann F., Lefranc G., Duroux P. (2009) IMGT, the international ImMunoGeneTics information system. Nucleic Acids Res. 37:D1006-D1012.

Leiro J., Ortega M., Estévez J., Ubeira F. M., Sanmartín M. L. (1996) The role of opsonization by antibody and complement in in vitro phagocytosis of microsporidian parasites by turbot spleen cells. Vet Immunol Immunopathol. 51:201-210.

Lindenstrom T., Buchmann K. (2000) Acquired resistance in rainbow trout against Gyrodactylus derjavini. J Helminthol. 74:155-160.

Makesh M., Sudheesh P. S., Cain K. D. (2015) Systemic and mucosal immune response of rainbow trout to immunization with an attenuated Flavobacterium psychrophilum vaccine strain by different routes. Fish Shellfish Immunol. 44:156-163.

Mashoof S., Criscitiello F. M. (2016) Fish immunoglobulins. Biology. 5:45.

Miller R. A., Harbottle H. (2018) Antimicrobial drug resistance in fish pathogens. Microbiol Spectr. 6.

Miqueu P., Guillet M., Degauque N., Dore J. C., Soulillou J. P., Brouard S. (2007) Statistical analysis of CDR3 length distributions for the assessment of T and B cell repertoire biases. Mol Immunol. 44:1057-1064.

Overath P., Haag J., Mameza M. G., Lischke A. (1999) Freshwater fish trypanosomes: Definition of two types, host control by antibodies and lack of antigenic variation. Parasitology. 119:591-601.

Page A., Fusil F., Cosset F. L. (2020) Towards physiologically and tightly regulated vectored antibody therapies. Cancers. 12:962.

Perdiguero P., Martín-Martín A., Benedicenti O., Díaz-Rosales P., Morel E., Muñoz-Atienza E., García-Flores M., Simón R., Soleto I., Cerutti A., Tafalla C. (2019) Teleost IgD+ IgM- B cells mount clonally expanded and mildly mutated intestinal IgD responses in the absence of lymphoid follicles. Cell Rep. 29:4223-4235.e5.

Pérez-Sánchez J., Naya-Català F., Soriano B., Piazzon M., Hafez H., Gabaldón T., Llorens C., Sitjà-Bobadilla A., 
Calduch-Giner J. (2019) Genome sequencing and transcriptome analysis reveal recent species-specific gene duplications in the plastic gilthead sea bream (Sparus aurata). Front Mar Sci. 6:760.

Piazzon M. C., Calduch-Giner J. A., Fouz B., Estensoro I., Simó-Mirabet P., Puyalto M., Karalazos V., Palenzuela O., Sitjà-Bobadilla A., Pérez-Sánchez J. (2017) Under control: How a dietary additive can restore the gut microbiome and proteomic profile, and improve disease resilience in a marine teleostean fish fed vegetable diets. Microbiome. 5:164.

Piazzon M. C., Estensoro I., Calduch-Giner J. A., del Pozo R., Picard-Sánchez A., Pérez-Sánchez J., Sitjà-Bobadilla A. (2018) Hints on T cell responses in a fish-parasite model: Enteromyxum leei induces differential expression of T cell signature molecules depending on the organ and the infection status. Parasit Vectors. 11:443.

Piazzon M. C., Galindo-Villegas J., Pereiro P., Estensoro I., Calduch-Giner J. A., Gómez-Casado E., Novoa B., Mulero V., Sitjà-Bobadilla A., Pérez-Sánchez J. (2016) Differential modulation of IgT and IgM upon parasitic, bacterial, viral, and dietary challenges in a perciform fish. Front Immunol. 7:637.

Piazzon M. C., Mladineo I., Naya-Català F., Dirks R. P., Jong-Raadsen S., Vrbatovic A., Hrabar J., Pérez-Sánchez J., Sitjà-Bobadilla A. (2019) Acting locally - affecting globally: RNA sequencing of gilthead sea bream with a mild Sparicotyle chrysophrii infection reveals effects on apoptosis, immune and hypoxia related genes. BMC Genomics. 20:200.

Picard-Sánchez A., Estensoro I., del Pozo R., Piazzon M. C., Palenzuela O., Sitjà-Bobadilla A. (2019) Acquired protective immune response in a fish-myxozoan model encompasses specific antibodies and inflammation resolution. Fish Shellfish Immunol. 90:349-362.

Picard-Sánchez A., Estensoro I., del Pozo R., Palenzuela O., Piazzon M. C., Sitjà-Bobadilla A. (2020) Water temperature, time of exposure and population density are key parameters in Enteromyxum leei fish-to-fish experimental transmission. J Fish Dis. 43:491-502.

Ramirez-Gomez F., Greene W., Rego K., Hansen J. D., Costa G., Kataria P., Bromage E. S. (2012) Discovery and characterization of secretory IgD in rainbow trout: Secretory IgD is produced through a novel splicing mechanism. J Immunol. 188:1341-1349.

Rajan B., Løkka G., Koppang E. O., Austbø L. (2017) Passive immunization of farmed fish. J Immunol. 198:41954202.

Ronza P., Estensoro I., Bermúdez R., Losada A. P., Pérez-Cordón G., Pardo B. G., Sitjà-Bobadilla A., Quiroga M. I. (2020) Effects of Enteromyxum spp. (Myxozoa) infection in the regulation of intestinal E-cadherin: Turbot against gilthead sea bream. J Fish Dis. 43:337-346.

Ryo S., Wijdeven R. H. M., Tyagi A., Hermsen T., Kono T., Karunasagar I., Rombout J. H. W. M., Sakai M., Kemenade B. M. L. V. van, Savan R. (2010) Common carp have two subclasses of bonyfish specific antibody IgZ showing differential expression in response to infection. Dev Comp Immunol. 34:1183-1190.

Saeij J. P., Vries B. J. D., Wiegertjes G. F. (2003) The immune response of carp to Trypanoplasma borreli: Kinetics of immune gene expression and polyclonal lymphocyte activation. Dev Comp Immunol. 27:859-874.

Salinas I., Zhang Y. A., Sunyer J. O. (2011) Mucosal immunoglobulins and B cells of teleost fish. Dev Comp Immunol. 35:1346-1365.

Sánchez-Martínez J., Speare D., Markham R. (2008) Altered tissue distribution of Loma salmonae: Effects of natural and acquired resistance. J Fish Dis. 24:33-40.

Saulnier D., de Kinkelin P. (1996) Antigenic and biochemical study of PKX, the myxosporean causative agent of proliferative kidney disease of salmonid fish. Dis Aquat Organ. 27:103-114.

Shugay M., Bagaev D. V., Turchaninova M. A., Bolotin D. A., Britanova O. V., Putintseva E. V., Pogorelyy M. V., Nazarov V. I., Zvyagin I. V., Kirgizova V. I., Kirgizov K. I., Skorobogatova E. V., Chudakov D. M. (2015) VD- Jtools: Unifying post-analysis of T cell receptor repertoires. PLoS Comput Biol. 11:e1004503.

Sitjà-Bobadilla A. (2008) Fish immune response to Myxozoan parasites. Parasite 15:420-425.

Sitjà-Bobadilla A., Diamant A., Palenzuela O., Álvarez-Pellitero P. (2007a) Effect of host factors and experimental 
conditions on the horizontal transmission of Enteromyxum leei (Myxozoa) to gilthead sea bream, Sparus aurata L., and European sea bass, Dicentrarchus labrax (L.). J Fish Dis. 30:243-250.

Sitjà-Bobadilla A., Gil-Solsona R., Estensoro I., Piazzon M. C., Martos-Sitcha J. A., Picard-Sánchez A., Fuentes J., Sancho J. V., Calduch-Giner J. A., Hernández F., Pérez-Sánchez J. (2019) Disruption of gut integrity and permeability contributes to enteritis in a fish-parasite model: A story told from serum metabolomics. Parasite Vector. 12:486.

Sitjà-Bobadilla A., Palenzuela O. (2012) Enteromyxum species, in: Woo P. T. K., Buchmann K. (Eds.) Fish Parasites: Pathology and Protection. CAB International, Oxfordshire, UK. pp. 163-176.

Sitjà-Bobadilla A., Palenzuela O., Riaza A., Macias M.A., Álvarez-Pellitero P. (2007b) Protective acquired immunity to Enteromyxum scophthalmi (myxozoa) is related to specific antibodies in Psetta maxima (L.) (Teleostei). Scand J Immunol. 66:26-34.

Sitjà-Bobadilla A., Redondo M. J., Macias M. A., Ferreiro I., Riaza A., Álvarez-Pellitero P. (2004) Development of immunohistochemistry and enzyme-linked immunosorbent assays for the detection of circulating antibodies against Enteromyxum scophthalmi (Myxozoa) in turbot (Scophthalmus maximus L.). Fish Shellfish Immunol. 17:335345.

Sitjà-Bobadilla A., Schmidt-Posthaus H., Wahli T., Holland J. W., Secombes C. J. (2015) Fish immune responses to Myxozoa, in: Okamura B., Gruhl A., Bartholomew J. L. (Eds.) Myxozoan Evolution, Ecology and Development. Springer International Publishing, Switzerland. pp. 253-280.

Tadiso T. M., Krasnov A., Skugor S., Afanasyev S., Hordvik I., Nilsen F. (2011) Gene expression analyses of immune responses in Atlantic salmon during early stages of infection by salmon louse (Lepeophtheirus salmonis) revealed biphasic responses coinciding with the copepod-chalimus transition. BMC Genomics. 12:141.

Tian J. Y., Sun B. J., Luo Y. P., Zhang Y. A., Nie P. (2009) Distribution of IgM, IgD and IgZ in mandarin fish, Siniperca chuatsi lymphoid tissues and their transcriptional changes after Flavobacterium columnare stimulation. Aquaculture. 288:14-21.

Wiegertjes G. F., Groeneveld A., van Muiswinkel W. B. (1995) Genetic variation in susceptibility to Trypanoplasma borreli infection in common carp (Cyprinus carpio L.). Vet Immunol Immunopathol. 47:153-161.

Xu J. L., Davis M. M. (2000) Diversity in the CDR3 region of $\mathrm{V}(\mathrm{H})$ is sufficient for most antibody specificities. Immunity. 13:37-45.

Ye J., Kaattari I. M., Ma C., Kaattari S. (2013) The teleost humoral immune response. Fish Shellfish Immunol. 35:1719-1728.

Zhang J., Kobert K., Flouri T., Stamatakis A. (2014) PEAR: A fast and accurate Illumina Paired-End reAd mergeR. Bioinformatics. 30:614-620.

Zhang Y. A., Salinas I., Li J., Parra D., Bjork S., Xu Z., LaPatra S. E., Bartholomew J., Sunyer J. O. (2010) IgT, a primitive immunoglobulin class specialized in mucosal immunity. Nat Immunol. 11:827-835.

Zimmerman A. M., Moustafa F. M., Romanowski K. E., Steiner L. A. (2011) Zebrafish immunoglobulin IgD: Unusual exon usage and quantitative expression profiles with IgM and IgZ/T heavy chain isotypes. Mol Immunol. 48:2220-2223. 
CHAPTER 3 


\section{SUPPLEMENTARY MATERIAL}

Supplementary Table 1. Primers used for repertoire analysis in gilthead sea bream.

\begin{tabular}{l|l|l}
\hline Primer name & Sequence & VH family* \\
\hline IgHV1-1-FW & TCAGACAGGCTCCTGGAAAAG & ighv6-1, ighv6-2, ighv10-1 \\
\hline IgHV1-2-FW & AAGGAAAAGGACTGGAGTGG & ighv3-1, ighv11-2 \\
\hline IgHV4-FW & AGGGAAAGCTCTGGAGTGGAT & ighv2-2 \\
\hline IgHV8-FW & CTGGATCAGACAACCTGCAG & ighv4-1, ighv4-2, ighv4-5 \\
\hline IgHV6-FW & TGGATCAGACAGCCTGCAG & ighv5-7 \\
\hline IgHV12-1-FW & TGAAGGAAAACCAATGGACTGGAT & ighv5-1, ighv5-5 \\
\hline IgHCt1-RV & AACCAAAGGAAACAGAGTCGG & Isotype (domain) \\
\hline Primer name & Sequence & IgM (C 42$)$ \\
\hline IgHCm2-2-RV & GAACGTAACGGCTGGTGGATT & \\
\hline & & \\
\hline
\end{tabular}

*Provisional names based on domain prediction and similarity with zebrafish VH genes. 
Supplementary Table 2. Summary of sequence analysis for the gilthead sea bream repertoire study. The total sequence column represents the sequences catalogued using the isotype specific primers as barcodes. These correspond to the input datasets for IMGT/HighV-QUEST analysis and were further analysed using VDItools software.

\begin{tabular}{|c|c|c|c|c|c|}
\hline Isotype & Sample & Total Sequences ${ }^{1}$ & Productive $^{2}$ & $\%$ & Unique Productive $^{3}$ \\
\hline \multirow[t]{7}{*}{ IgM } & NAI1 & 1212502 & 1111726 & 91.69 & 27893 \\
\hline & NAI2 & 1085478 & 946860 & 87.23 & 18975 \\
\hline & NAI3 & 1364383 & 1239361 & 90.84 & 31576 \\
\hline & NAI4 & 1198061 & 1102736 & 92.04 & 54676 \\
\hline & SUR1 & 1945213 & 1860441 & 95.64 & 88564 \\
\hline & SUR2 & 1282689 & 1245484 & 97.10 & 42655 \\
\hline & SUR4 & 1279122 & 1225746 & 95.83 & 68045 \\
\hline \multirow[t]{8}{*}{ IgT } & NAI1 & 306390 & 256978 & 83.87 & 5088 \\
\hline & NAI2 & 425306 & 322885 & 75.92 & 5182 \\
\hline & NAI3 & 222954 & 140843 & 63.17 & 3710 \\
\hline & NAI4 & 261887 & 223047 & 85.17 & 10054 \\
\hline & SUR1 & 695011 & 662240 & 95.28 & 19238 \\
\hline & SUR2 & 203544 & 189540 & 93.12 & 8905 \\
\hline & SUR3 & 334300 & 310810 & 92.97 & 12328 \\
\hline & SUR4 & 387898 & 341613 & 88.07 & 20453 \\
\hline
\end{tabular}

\footnotetext{
${ }^{1}$ Total sequences used as input for IMGT-HighVQuest after quality filtering. ${ }^{2}$ Total productive sequences according to IMGT-HighVQuest. ${ }^{3}$ Functional clonotypes according to parse from VDJtools.
} 
Supplementary Figure 1. Rabbit IgG detection in gilthead sea bream serum after intracoelomic (i.c.) injection. Gilthead sea bream $(n=3)$ were i.c. injected with $10 \mu \mathrm{l} / \mathrm{g}$ of rabbit serum and $50 \mu \mathrm{l}$ of blood were extracted after $0,35 \mathrm{~min}, 1,2,5 \mathrm{~h}, 1,5,7$ and 9 days post-injection to obtain serum. For the dot-blot, $2 \mu \mathrm{l}$ of each serum were transferred to a nitrocellulose membrane and the membranes were blocked for $1 \mathrm{~h}$ with $20 \mathrm{mM}$ Tris 0.5 $\mathrm{M} \mathrm{NaCl} \mathrm{pH} 7.4$ (TBS) 5\% (w/v) non-fat dry milk. Then, membranes were incubated with a 1:20,000 dilution of goat anti-rabbit-HRP (Sigma) in TBS $1 \%$ (w/v) non-fat dry milk for $1 \mathrm{~h}$, washed with TBS, and visualized by chemiluminescence detection with ClarityTM Western ECL substrate (Bio-Rad) in an Amersham Imager 600 (GE Healthcare, Little Chalfont, UK). Two $\mu$ l of undiluted rabbit serum were used as a positive control. The figure depicts representative images of the dot-blot results for each time point.

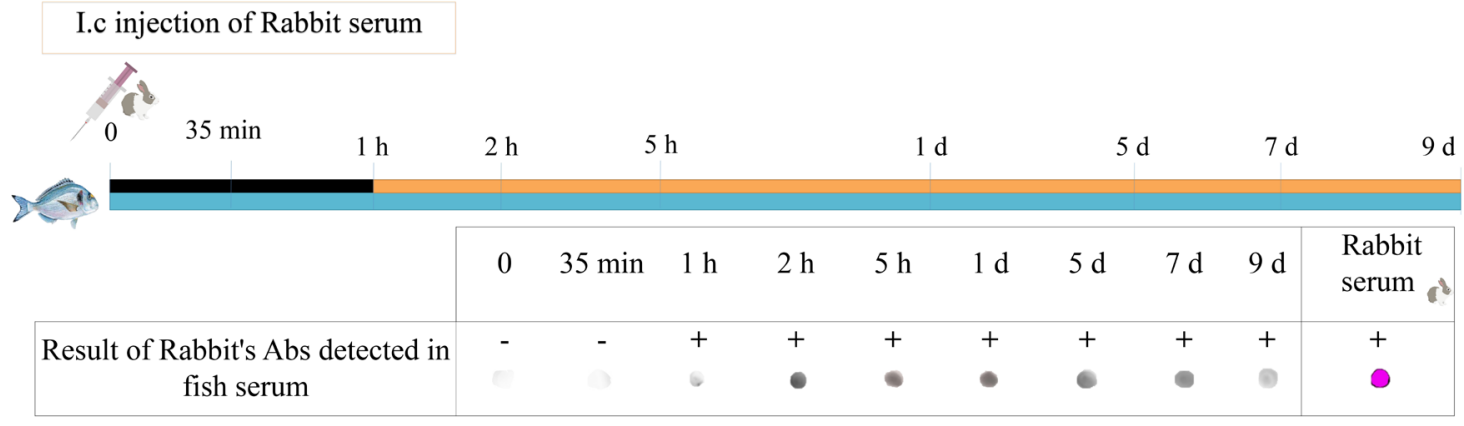

Supplementary Figure 2. PCR amplification of the different combinations of forward and reverse primers in the gilthead sea bream repertoire analysis. Seven forward primers were designed to amplify the $46 \mathrm{VH}$ sequences predicted from the genome. Reverse primers were specific for IgM or IgT. One PCR reaction for each of the combinations was performed on cDNA from anterior intestine of four naïve fish (NAI) and four fish that survived an Enteromyxum leei infection and became resistant to reinfection (SUR).

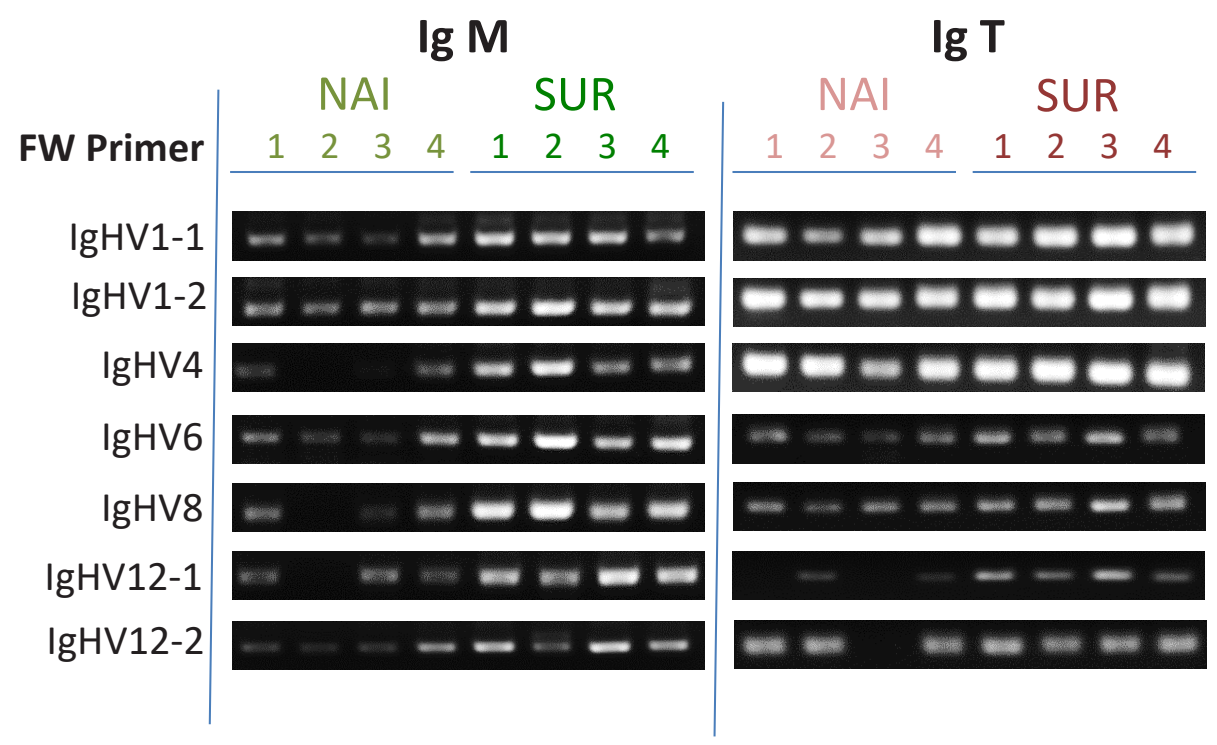


Supplementary Data 1. IGHV candidate sequences identified from the gilthead sea bream genome. The nomenclature of each gene is provisional and was performed by identifying the most similar IGHV gene in zebrafish.

>ighv2-2like.1

GAATGTCATTTAAATCACGCTTGTTGTCTGTGGAGGTTTTTGTGCAGCTGCTCCACTGTCTTCAGTCACTGTGTCTCTCGAGCACAGAAGTAAACAGCAGAATCTTCTGCTGTCAGGCTCCTGATCTCGAGGTACTGAGTGCTGCTGGACACGTCTTCAGTCATGAGGAAACCACTTTGAAAGGAGCTGGCATAGATTGCAGAGTTTTTTCCAGTATCCATCCTCCCAATCCACTCCAGAGCTTTCCCTGGCTTCTGTCGTATCCAGTGAATATTGCGGCTCGTCATGCTATAACCAGATATGATACATGACATCTTCACTGTCTCTCCAGGTGTTTTCACCTCAGAGGGAGACTGGTCCAGTTTG

>ighv2-2like.2 TACAACACGTCGACACCCACATTTTCGTGTCAATACATTTTTTTTAATCGTTGTAGCCCTAGTCTCTACGAGCCCAGAAGTAAACAGCAGAATCTTCTGCTGTCAGGCTCCTGATCTCGAGGTACTGAGTGCCGCTGGGCACGTCTTCAGTCATGAGGAAACCACTTTGAAAGGAGCTGGCATAGATTGCAGAGTTTTTTCCAGTATCCATCCTCCCAATCCACTCCAGAGCTTTCCCTGGCTTCTGTCGTATCCAGTTAATAGCGTAGCTCGTCATGCTATAACCAGATATGATACATGACATCTTCACTGTCTCTCCGGGTGTTTTCACCTCAGAGGGAGACTGGTCCAGTTTG

>ighv2-2like.3 GATGAAGCCCACTGGGGAGGTTTTTGTGCAGCTGCTCCACTGTCTTCAGTCACTGTGTCTCTACGAGCACAGAAGTAAACAGCAGAATCTTCTGCTGTCAGGCTCCTGATCTCGAGGTACTGAGTGCTGCTGGACACGTCTTCAGTCATGAGGAAACCACTTTGAAAGGAGCTGGCATAGCTAGCAGAGTTTGAACCTGCGTTCATCCTCCCAATCCACTCCAGAGCTTTCCCTGGCTTTTGTCGTATCCAGTGAATAAAGTAGTCTGTCATGTCAAACCCAGATATGATACATGACATCTTCGCTGTCTCTCCGGGTGTTTTCACCTCAGAGGGAGACTGGTCCAGTTTG

>ighv2-2like.4 GAAGGTCACATGTTTGTTGTCTGTAGAGGTTTTTGTGCAGCTGCTCCACTGTCTTCAGTCACTGTGTCTCTGCGAGCACAGAAGTAAACAGCAGAATCTTGTGCTGTCAGGCTCCTGATCTCGAGGTACTGAGTGCTGCTGGACACATCTTCAGTCATGAGGGAACCACTTTGAAAGGAGCTGGCATAGCTAGCAGAGTTTGAACCTGTGCTCATCCACCCAATCCACTCCAGAGCTTCCCCTGGTTTCTGTCGTATCCAGACCATATTAGCACTCTTCATGCTATAACCAGATATGATACATGACATCTTCACTGTCTCTCCAGGTCTTTTCACCTCAGAGGGAGACTGGTCAAGTTTG

>ighv2-2like.5 GAAGATCACATGTTTGTTGTCTGTGGAGGTTTTTGTGCAGCTGCTCCACTGTCTTCAGTCACTGTGTCTCTCGAGCACAGAAGTAAACAGCAGAATCTTCTGCTGTCAGGCTCCTGATCTCGAGGTACTGAGTGCTGCTGGACACGTCTTCAGTCATGAGGAAACCACTTTGAAAGGAGCTGGCATAGATAGCAGAGTTTCAACCTGTGTTCATCCACCCAATCCACTCCAGAGCTTTCCCTGGCTTCTGTCGTATCCAGACCATATTGTAGCTCATCATGCTATAACCAGATATGACACATGACATCTTCACTGTCTCTCCAGGTGTTTTCACGTCAGAGGGAGACTGGTCCAGTTTG

>ighv2-2like.6 GAAGATCACATGTTTGTTGTCTGTGGAGGTTTTTGTGCAGCTGCTCCACTGTCTTTAGTCACTGTGTCTCTCGAGCACAGAAGTAAACAGCAGAATCTTCTGCTGTCAGGCTCCTGATCTCGAGGTACTGAGTGCTGCTGGACACGTCTTCAGTCATGAGGAAACCACTTTGAAAGGAGCTGGCATAGATAGCAGAGTTTGAACCTGCGTTCATCCTCCCAATCCACTCCAGAGCTTTCCCTGGATTCTGTTGTATCCAGTAAATATTGTAGCTCGTCATTCTATGACCAGATATGATACATGACATCTTCACTGTCTCTCCAGTAGGGCTGGGCGATTATGCTAAAAATAATAATCAAGATTA

>ighv2-2like.7 GAAGATCACATGTTTGTTGTCTGGGGAGGTTTTTGTGCAGCTGCTCCACTGTCTTCAGTCACTGTGTCTCTCGAGCACAGAAGTAAACAGCAGAATCTTCTGCTGTCAGGCTCCTGATCTCGAGGTACTGAGTGCTGCTGGACACGTCTTCAGTCATGAGGAAACCACTTTGAAAGGAGCTGGCATAGCTAGCAGAGTTGTAACCTGTGTTCATCCACCCTATCCACTCCAGAGCTTTCCCTGGCTTCTGTCGTATCCAGTGAATATTGTAGTCTGTCATGTCAAACCCAGATATGATACATGACATCTTCACTGTCTCTCCAGGTGTTTTCACCTCAGAGGGAGACTGGTCCAGTTTG

>ighv2-2like.8 GAAGATCACATGTTTGTTGTCTGGGGAGGTTTTTGTGCAGCTGCTCCACTGTCTTCAGTCACTGTGTCTCTCGAGCACAGAAGTAAACAGCAGAATCTTCTGCTGTCAGGCTCCTGATCTCGAGGTACTGAGTGCTGCTGGACACGTCTTCAGTCATGAGGAAACCACTTTGAAAGGAGCTGGCATAGCTAGCAGAGTTGTAACCTGTGTTCATCCACCCTATCCACTCCAGAGCTTTCCCTGGCTTCTGTCGTATCCAGTGAATATTGTAGTCTGTCATGTCAAACCCAGATATGATACATGACATCTTCACTGTCTCTCCAGGTGTTTTCACCTCAGAGGGAGACTGGTCCAGTTGATCTC

>ighv3-2like.1 GAAAGTAAAGTTTTGACTTGTTTTGAAATGTTGAGTTTTTGTACAGCGTTGCTCCTTCCTGTGTCACTGTGTCTCTCGAGCACAATAATAAACAGCAGAATCTTCAGTCTTCAGACTGTTCATCTGCAGATACACCTGCTGTCTGCTGTTGTCTCTGGAGATGGTAAACCGGCCTTTGACTGTTTCAGAGTAGTAAGTGCTGCCACCACTAGGATAGATCTCAGCAAGCCACTCCAGTCCTTTTCCAGGAGCCTGTCTGATCCAGTGCATAGCATAGTCACTGAATGTGAATCCAGAGGCTGTACAGGTCAATCTGTGAGATTCTCCAGGCCTTTTAACCACTGGTTCAGATTCTGTCAGAGTCTG

>ighv3-2like.2 AACTGTTATTATTTTTCAGGCTCTTTCAGCCCAGTAAAGATGAGTTCTGTAGGTTTTTGTACAGCTGCTCAACAATTCCAGTCACTGTGGCTCTCGAGCACAATAATAAACAGCAGAATCTTCAGTCTTCAGACTGTTCATCTGCAGATACACCTGCTGTCTGCTGTTGTCTCTGGAGATGGTAAACCGGCCTTTGACTGACTCAGAGTAGTAGATGTAGCTACTGCCATCACTACTGATATAAGCAACCCACTCCAGTCCTTTTCCAGGAGCCTGTCTGATCCAGTTCATAGGA- 
GAGCTGCTGAATGTGAATCCAGAGGCTGTACAGGTCAATCTGTGAGATTCTCCAGGCCTTTTAACCACTGGTTCAGATTCTGTCAGAGTCTG

>ighv3-2like.3 CAGGTGCAAAACTGAAAGTTTTTGGCGGCCCTCTAGGTGGCGCTTGCGGCCCAAGCTTGGGCCGCGGCCCTATGGTTAAGAATCACTGGTCTAAATCAAGTGAAAATACGCAGAAGAAGACACTACAAGTTGTTTTTACATGTTGAGTTTTTGTTAAGGGTTGCTCCTTCCTGTGTTGCTGTGGCTGTCGAGCACAATAATAAACAGCAGAATCTTTAGTCTTCAGACTTCAGACTTCCTTTTCCAGGAGCCTGTCTGATCCAGTTCATCTCGTAGCTGCTGAATGTGAATCCAGAGGCTGTACAGGTCAATCTGTGAGATTCTCCAGGCCTTTTAACCACTGGTTCAGATTCTGTCAGAGTCTG

$>$ ighv3-2like.4 CCCAGTAAAGATGAATTCTGTAGGTTTCTGTACAGCTGCTCAACCAACTCCAGTCACTGTGGCTGTCGAGCACAATAATAAACAGCAGAATCTTCAGTCTTCAGACTGTTCATCTGCAGATACACCTGCTGTCTGCTGTTGTCTCTGGAGATGGTAAACCGGCCTTTCACTGACTCAGAGTAGTAGATGTAACTACTGCCACTGCTGATATACGCAACCCACTCCAGTCCTTTTCCAGCAGCCTGTCTGATCCAAGCAGTATTGATACTGCCACCAAACCCTGAATATGTGCAGGTCAAACTGTGGGATTCTCCAGGTCTTTTAACCGCAGGTTCAGACTCAGTTAGTGTTTG

>ighv3-2like.5 CCCAGTAAAGATGAATTCTGTAGGTTTCTGTACAGCTGCTCAACCAACTCCAGTCACTGTGGCTGTCGAGCACAATAATAAACAGCAGAATCTTCAGTCTTCAGACTGTTCATCTGCAGATACACCTGCTGTCTGCTGTTGTCTCTGGAGATGGTAAACCGGCCTTTCACTGACTCAGAGTAGTAGATGTAACTACTGCCACTGCTGATATACGCAACCCACTCCAGTCCTTTTCCAGCAGCCTGTCTGATCCAAGCAGTATTGATACTGCCACCAAACCCTGAATATGTGCAGGTCAAACTGTGGGATTCTCCAGGTCTTTTAACCGCAGGTTCAGACTCAGTTAGTGTTTG

>ighv3-2like.6 ATGCTTCATGTTTTGGCTCCTTCAGCCCAGTAAAGATGAGTTCTGTAGGTTTTTGTACAGCTGCTCAACAACTCCAGTCACTGTGGCTTTCGAGCACAATAATAAACAGCAGAATCTTCAGTCTTCAGACTGTTCATCTGCAGATACACCTGCTGTCTGCTGTTGTCTCTGGAGATGGTAAACCGGCCTTTGACTGACTCAGAGTAGTATTGTTTGCTACCACTAGGTTGACTGACTAAAGCAACCCACTCCAGTCCTTTTCCAGGAGCCTGTCTGATCCAGTGCATCTCATAGTCACTGAATGTGAATCCAGAGGCTGTACAGGTCAATCTGTGAGATTCTCCAGGCCTTTTAACCACTGGTTCAGATTCTGTCAGAGTCTG

>ighv3-2like.7 ATGCTTCATGTTTTGGCTCCTTCAGCCCAGTAAAGATGAGTTCTGTAGGTTTTTGTACAGCTGCTCAACAACCCAGTCACTGTGGCTTTCGAGCACAATAATAAACAGCAGAATCTTCAGTCTTCAGACTGTTCATCTGCAGATACACCTGCTGTCTGCTGTTGTCTCTGGAGATGGTAAACCGGCCTTTGACTGACTCAGAGTAGTATTGTTTGCTACCACTAGGTTGACTGACTAAAGCAACCCACTCCAGTCCTTTTCCAGGAGCCTGTCTGATCCAGTGCATCTCATAGTCACTGAATGTGAATCCAGAGGCTGTACAGGTCAATCTGTGAGATTCTCCAGGCCTTTTAACCACTGGTTCAGATTCTGTCAGAGT

>ighv4-1like.1 GTAGGTCTTTGGAAACAAATGTTCTGTGGAGTTTTTGTAAAGCTTCTCTGCTTCCTTTAACCAGTGTGTGTGTTTGGCACAGTAATACACAGCAGAGTCCTCTGGCTTTAAGTTGGACAGTCTCAGATACACCATGCTGTTGCTATCTTCTCTACTGATTTCTGCACGTCCTCGCACACTGCTGGCATAAGTGTTACTACTTGCATCAGTGAAGCCTTCCCCGATCCATTCCTAGTCCTTTTCCTGCAGGTTGTCTGATCCAGCTCATAGTGCAGCAGCTGAATGTGAAGCCAGATCCCATGCAGGACAGACTGAGAGTCTCCCCAGGCTTTTTCACTACTGAACTGGAAGGAATGGACTCCA

>ighv4-2like.1 GTAGGTCTTTGGAAACAAATGTTCTGTGGAGTTTTTGTAAAGCTTCTCTGCTTCCTTTAACCAGTGTGTGTGTTTGGCACAGTAATACACAGCAGAGTCCTCTGGCTTTAAGTTGGACAGTCTCAGATACACCATGCTGTTGCTATCTTCTCTACTGATTTCTGCACGTCCTCGCACACTGCTGGCATAAGTGTTACTACTGGAGCTGGAGTAGCCATTCCCGATCCATTCCAGTCCTTTTCCTGCAGGTTGTCTGATCCAGCTCATAGTGCAGCAGCTGAATGTGAAGCCAGATCCCCTGCAGGACAGACTGAGAGTCTCCCCAGGATTTTTCACTACTGAACTGGAAGGAATTGACTCCATACTCTG

>ighv4-2like.2 GTAGGTCTTTGGAAACAAATGTTCTGTGGAGTTTTTGGAAAGCTTCTCTGCTTCCTTTAACCAGTGTGTGTGTTTGGCACAGTAATACACAGCAGAGTCCTCTGGCTTTAAGTTGGACAGTCTCAGATACACCATGCTGTTGCTATCATCTCTACTGATTTCTGCACGTCCTCGCACACTGCTGGCATAAGTGTTACTACTGGAGCTGGAGAAGCCAACCCCGATCCATTCCAGTCCTTTTCCTGCAGGTTGTCTGATCCAGCTCATAGTGCAGCAGCTGAATGTGAAGCCAGATCCCATGCAGGACAGACTGAGAGTCTCCCCAGGCTTTTTCGCTACTGAACTGGAAGGAATGGACTCCA

>ighv4-2like.3 GTAGGTCTTTGGAAACAAATGTTCTGTGGAGTTTTTGTAAAGCTTCTCTGCTTCCTTTAACCAGTGTGTGTGTTTGGCACAGTAATACACAGCAGAGTCCTCTGGCTTTAAGTTGGACAGTCTCAGATACACCATGCTGTTGCTGTCATCTCTACTGATTTCTGCACGTCCTCGCACACTGCTGGCATATGTGTTTTTACTGGAGGTGGAGTAGCCAACCCCGATCCATTCCAGCCATTTTACTGCAGGTTGTCTGATCCAGTGCATACTGCAGCAGCTGAATGTGAAGCCAGATCCCCTGCAGGACAGACTGAGAGTCTCCCCAGGCTTTTTCACTACTGAACTGGAAGGAATGGACTCC

>ighv4-5like.1 GTAGGTCTTTGGAAACAAATGTTCTGTGGAGTTTTTGTAAAGCTTCTCTGCTTCCTTTAACCAGTGTGTGTGTTTGGCACAGTAATACACAGCAGAGTCCTCTGGCTTTAAGTTGGACAGTCTCAGATACACCATGCTGTTGC- 
TATCTTCTCTACTGATTTCTGCACGTCCTCGCACACTGCTGGCATAAGTGTTACTACTTGCATCAGTGAAGCCTTCCCCGATCCATTCCTAGTCCTTTTCCTGCAGGTTGTCTGATCCAGCTCATAGTGCAGCAGCTGAATGTGAAGCCAGATTAATGTCAGGGTTTTCCCTGCCATTATACGGCTTAGGCGTGGCGCCCAAGCGTTTTGCCTCCCGCCTAAGCAGG

>ighv5-1like.1 GTTGAGTCACATGGTCTCTGGGTATTTGTGCAGGTCTGTTGGTGGTTTGTATCACTGTGGGCTGACGTAGACAGTAATAAACAGCTGTGTCCTCAGGCTGCAGATTCTGTCCTGTTAGAGTCACTGTTCTAGCAGAAGTGTCTCTGCTGTAGCTGAACTTGTTCTTCAGAGCATTATTTTGATAAAGGCCACCTCCACCCCATATGGAAAATCCAGTCCATTGGTTTTCCTTCACACTTGTCTTCAATGTGTACACTGAATTAATTTCATTACTTGACTTTATCATGTACTTAAATTAAATGTACTGTAATTTGTTTAAGAAAATGGATCACCCTTTATGAAGCCCAAGTATTTAAGTTGAAATTGAATTAA

>ighv5-3like.1 AATGCATTACTTTGTACAAGTGTTCAGGCACTGAGGGGTTTTTGTTCAGGTCTACTGATGGTTTGTGTTATTGTGGCTCTCTGGCACAGTAATACACAGCAGTGTCTTCAGACTGCACATTATGTCCATTTAGAGTCACTGTGTTGCTGGAAAGGTCTGTTGACTGTTATTATATCTGTAGAGTGAAAACTTGCCTGGAAATCACCTCTGCTTTACACATGATATTTTCATTTCATTACACACTCAACTGTAACATGCTCCTCCTGTGCTGACACACTGACACTGACTTCATTCACCTGAAATGAGAGTCAAGAAGAAGAAACTTAGTACAACTTGGCTGAGTCTGCAACTGCAAAGGATATATGAAGGATATACACCGATCAG

>ighv5-3like.2 AATGCATTACTTTGTACAAGTGTTCAGGCACTGAGGGGTTTTTGTTCAGGTCTACTGATGGTTTGTGTTATTGTGGCTCTCTGGCACAGTAATACACAGCAGTGTCTTCAGACTGCACATTATGTCCATTTAGAGTCACTGTGTTGCTGGAAAGGTCTGTTGACTGTTATTATATCTGTAGAGTGAAAACTTGCCTGGAAATCACCTCTGCTTTACACATGATATTTTCATTTCATTACACACTCAACTGTAACATGCTCCTCCTGTGCTGACACACTGACACTGACTTCATTCACCTGAAATGAGAGTCAAGAAGAAGAAACTTAGTACAACTTGGCTGAGTCTGCAACTGCAAAGGATATATGAAGGATATACACCGATCAG

>ighv5-5like.1 TACAATCTTGAAATTCAAGTTCAGATCCACATATATTGCAACACCACCACCCCCTTTGCTCTGTCTGTTTTAACACAGTAATAAACAGCTGTGTCCTCAGGCTGCAGATTCTGTCCTGTCAGAGTCACTGTTCTAGCAGAAGTGTCTCTGCTGTAGCTGAACTTGTTCTTCAGAGCAATATTTTGACAAAGGGTACCTCCACCCCACTGATGGGAAATCCAGTCCATTGGTTTTCCTTCACACTGTCTGATCCAACCTGTTGCATAGCTGTCATCAGTCAAATAATAACCAGAGACCTGACAGGTGATGGTCAAAGACTGTCCAGGCTGCACAACCTTTGAGTCTGGCTGGATGAGATCAA

>ighv5-5like.2 AACTTTTGTGGTTGAGTCACATGGTCTCTGGGTATTTGTGCAGGTCTGTTGGTGGTTTGTATCACTGTGGGCCGACGTACACAGTAATAAACAGCTGTGTCCTCAGGCTGCAGATTCTGTCCTGTTAGAGTCACTGTTCTAGAAGAAGTGTCTCTGCTGTAGCTGAACTTGTTCTTCAGAGCATTATTTTGATAAAAGTTGCCTCCACCCCACTGATAAGAGATCCAGTCCATTGGTTTTCCTTCACACTGTCTGATCCAACCTATTGCATAGCTGCTGTCAGTCAAAGAATAACCAGAGACCTGACAGGTGATGGTCAAAGACTGTCCAGGCTGCACAACCTTTGAGTCTGGCTGGATGAGATCAA

$>$ ighv5-7like.1

GACAAGTGAATGTTTCCAGTGGAGGTAAATAGAGGAAGTAGTTTTTGTATGACTCTCCTGTTATTGTCTCTCACTGTGGGTCTCTGGCACAGTAATACACAGCAGTGTCTTCAGACTGCACATTCTGTCCATTTAGAGTCAATGTTTTACTGGAAGAGTCTAAATCGATACTGAATTTGTTCTTTAGGGAATCTTTGTAGTATGTACTGTATCCAACACGTGCACTCCCAATCCACTCCAGTCCTTTCCCTGCAGGCTGTCTGATCCAGTGTGTGCGATAGCTGCTAACAGAATAAGAGACCTGACAGGTGATGGTCAGACGTTGACCTGGCTGCACAGTCACAGAGGCTGGCTGTATCAACTGTT

>ighv5-7like.2 TACTGAGACAACTGAATGTTTCCAGTGGTGGTAAATAGAGGAAGTACTTTTTGTAAGACTCTCCTGTTATTGTCTCACACTGTGTCTCTTCTGGCACAGTAATACACAGCAGTGTCTTCAGACTGCACATTCTGTCCATTTAGAGTCACTGTTTTACTGGAAGAGTCTAAATCGATACTGAATTTGTTCTTGAGGGAATCTTTTACTTGTGTGTCATCACCCATCCACTCCAGTCCTTTCCCTGCAGGCTGTCTGATCCAAGCTGTAGCATAGATGCTAACAGAATAAGAGACCTGACAGGTGATGGTCAGACGTTGACCTGGCTGCACAGTCACAGAGGCTGGCTTGTCAACTGTTCA

>ighv5-7like.3 GGTGGTAAATAGAGGAAGTAGTTTTTGTATGACTCTCTTATTATTGTCTCTCACTGTGGGTCGTCTGGCACAGTAATACACTGCAGTGTCTTCAGACTGCACATTCTGTCCATTTAGTGTCACTGTGTTGCTGGAAGAGTCTAAATTGACACTGAACTTGTTCTTTAGTGAATCTTTGACGTCAGTGTCATCACTCATCCACTCCAGTCCTTTCCCTGCAGGCTGTCTGATCCAAGCTGTGAAGTCGCTGCTAACAGAATAAGAGACCTGACAGGTGATGGTTAGACGTTGACCTGGCTGCACAGTCACAGAGGCTGGCTGTGTCAACTGT

>ighv5-7like.4 GAATGTTTCCAGTGGTGGTAAATAGAGGAAGTAGTTTTTGTATGACTCTCCTGTTATTGTCTCTCACTGTGGCTCTCTGGCACAGTAATACACAACAGTGTCTTCAGACTGCACATTCTGTCCATTCAGAGTCACTGTGTTGCTGGAAGAGTCTAAGTTGATACTGAACTTGCTCTTTAGTGAATCTTTGAAGTATGAGCCTCCAGTATTTTTCATCCCAATCCACTCCAGTCCTTTCCCTGCAGGCTGTCTGATCCAAGCTGTGTGGTAGCCAAGAAAATAAGAGACCTGACAGGTGATGGTCAGACGTTGACCTGGCTGCACAGTCACAGAGGCTGGCTGTGTCAACTGTTCA

>ighv5-7like.5 TCATGTTACAAGTGTTCAGGCACTGAGGGGTTTTTGTTCAGGTCTACTGATGGTTTGTGTTATTGTGGCTCTCTGGCGCAGTAATACACAGCAGTGTCTTCAGACTGCACATTCTGTCCATTTAGAGTCACTGTGTTGCTGGAAGAGTCTAAATCAATACTGAACTTGTTCTTTAGTGAATCTTTGTAGTACGAGGCTCTAGTGAATTTGCTTCCAATCCACTC- 
CAGTCCTTTCCCTGCAGGCTGTCTGATCCAAGCTGTCCAGTAGCTGCTAACAGAATAAGAGACCTGACAGGTGAGTCAGACGTTGACCTGGCTGCACAGTCACAGAGGCTGGCTGTGTCAACTGTTCA

>ighv5-7like.6 GGTGGTAAATAGAGGAAGTAGTTTTTGTATGACTCTCCTATTATTCTCTCTCACTGTGGTTCGTCTGGCACAGTAATTCACAGCAGTGTCTTCAGACTGCACATTCTGTCCATTTAGAGTCACTGTGTTACTGGAAGAGTCTACATTGACACTGAACTTGTTCTTAAGTGCATCTTTGACGTTAGTGTCATCACTCATCCACTCCAGTCCTTTCCCTGCAGGCTGTCTGATCCAAGTTGTGTAGTAGTCACTAACAGAATAAGAGACCTGACAGGCAGTGGTGTGCACAGGTAGACACTAGGTGGTGCTAAAGCACCTGCCCTTTGCCCTCTGGACCAAGCAAAAGCCCTTTTGAAAGTTTT

>ighv6-1like.1

GTGACTTTGTGCAGCACAACTCAGTTAGAAGAGGAAGTAGTTTTTGTATGACTCTCCTGTTATTGTCTCTCACTGTGTCTCTCTGGCACAGTAATACACTGCTGTGTCCTCAGTCATCTGTAGGTAGACTTTACTGCTGGAGTCATCTCTGGAGATGGTGAATCTACCCTTGACTGACTCGGAGTAATAGATAGGAGTACTATCTGTGTCTATAAAAGCAATCCACTTTTCCAGAAGCCTGTCTGATCCAGTTCCAGACTGAGCCTTCAAAGTCAAATCCAGATGTTGTGCAGGTGAGTCTGTGGGACTCTCCGGGTCTTTTAACTGCTGGTTCAGACTCTGTTATGGTCC

>ighv6-2like.

CATATTACATTTTCCACCAGTGTAGTAAACAGATGAAGTAGTTTTTGTATGACTCTCCTGTTATTGTCTCTCACTGTGTCTCTCTGGCACAGTAATACACTGCTGTGTCCTCAGTCTTCAGACTGTTCATCTGTAGGTAGACTTTACTGCTGGAGTCATCTCTGGAGATGGTGAATCTTCCCTTGACTGACTGGGTAATATAGATGCTAGTGCTGCCTGTGTGTATGAAAGCGATCCACTCCAGTCCTTTTCCAGGAGCCCCAGAGTAGAATTTCCTGCCATTATCATATTCAACCCAGGCAATCCACTCCAGTCCTTTTCCAGGAGCCTGTCTGACCCAGTTCATATCATAGCTGCTGAATGTGAATCCAGAGGTTGTACAGGTCAATCTGTGAGATTCTCCAGGCCTTTTAACCACTGGTTCAGATTCTTTCAGAGTCTG

>ighv10-1like.1 GGGCTCCCTCAACTCAGTAAAGATGAGTACTGTAGGTTTTTGTACAGCTGCTCAACAACTCCAGTCACTGTGTCTCTCGAGCACAATAATAAACAGCAGAATCTTCAGTCTTCAGACTGTTCATCTGCAGATACACCTGCTGTCTGCTGTTGTCTCTGGAGATGGTAAACCGGCCTTTGACTGACTCAGAGTAGTATTGGGTGCTACCACTGCTATAAATCCAGGCAACCCACTCCAGTCCTTTTCCAGGAGCCTGTCTGATCCAGTTCATATTGTAGCTGCTGAATGTGAATCCAGAGGCTGTACAGGTCAATCTGTGAGATTCTCCAGGCCTTTTAACCACTGGTTCAGATTCTGTCAAAGTCTG

>ighv10-1like.2 GTCAGACAGCAAAGATGAGTACTGTAGGTTTTTGTACAGCTGCTCAACCAACTCCAGTCACTGTGGCTCTCGAGCACAATAATAAACAGCAGAATCTTCAGTCTTCAGACTGTTATCTGCAGATACACCTGCTGTCTGCTGTTGTCTCTGGAGATGGTAAACCGGCCTTTGACTGACTCAGAGTAGTAGATGCTGTTACTGTCATATCTGATAGCAGCAACCCACTCCAGTCCTTTTCCAGGAGCCTGTCTGACCCAGTTCATCCAGTAGTCACTGAATGTGAATCCAGAGGCTGTACAGGTCAATCTCTGAGATTCTCCAGGCCTTTTAACCACTGGTTCAGATTCGGTCAGAGTCTG

>ighv10-1like.3 AATACTTCATACTTGGCTCCATCAGTCCAGTAAAGATGAGTACTGTAGGTTTTTGTACAGCTGCTCAACAACTCCAGTCACTGTGAGTCTCGAGCACAATAATAAACAGAATCTTCAGTCTTCAGACTGTTCATCTGCAGATACACCTGCTGTCTGCTGTTGTCTCTGGAGATGGTAAACCGGCCTTTGACTGACTCAGAGTAGTGGATGTTGCTACTGTCATAAATAGCAGCAACCCACTCCAGTCCTTTTCCAGGAGCCTGTCTGATCCAGTGCATCCAATAGCTACTAATTGACAGTCCAGAGGCTGTACAGGTCAATCTGTGAGATTCTCCAGGCCTTTTAACCACTGGTTCAGATTCTGTCAGAGTCTG

>ighv10-1like.4 CCCAGTAAAGATGAGTTCTGTAGGTTTTTGTACAGCTGCTCAACCAACTCCAGTCACTGTGGCTGTCGAGCACAATAATAAACAGCAGAATCTTCAGTCTTCAGACTGTTCATCTGCAGATACACCTGCTGTCTGCTGTTGTCTCTGGAGATGGTAAACCGGCCTTTGACTGACTCAGAGTAGTAGATGCTGTTACTGTCATATCTGATATACGCAATCCACTCCAGTCCTTTTCCAGGAGCCTGTCTGATCCAGTGCATCCAGTAGCTGCTGAGTGTGAATCCAGAGGCTGTACAGGTCAATCTGTGAGATTCTCCAGGCCTTTTAACCACTGGTTCAGATTCTGTCAGAGTCTG

>ighv10-1like.5 TCTATCAGCCCAGTAAAATTTAGCGCTGTAGGTTTTTGTGCAGCTGCTCAACCAACTGCGTTGCTGTGTGGCTGTGGAGCACAATAATAAACAGCAGAATCTTCAGTCTTCAGACTGTTCATCTGCAGATACACCTGTTGTCTGCTGTTGTCCCTGGAGATGGTAAACCAGCCTTTGACTGACTCAGAGTAGTACTGGGTGCTACCACTTCCACTGTAAATCCAGGCAACCCATTCCAGTCCTTTTCCGGGAGCCTGTCTGATCCAGCTCATCCAGTTGCTGCTGAAGGTGAATCCAGAGGCTGTACAGGTCAATCTATGAGATTCTCCAGGCCTTTTAACCACTGGTTCAGATTCTGTCAGAGTCTG

>ighv10-1like.6 GATCTTCAGCCCAGTAAAATTTTAGCGCTGTAGTTTTTGTGCAGCTGCTCAACAACTGCGTTGCTGTGTGGCTGTGGAGCACAATAATAAACAGCAGAATCTTCAGTCTTCAGACTGTTCATCTGCAGATACACCTGTTGTCTGCTGTTGTCCCTGGAGATGGTAACCAGCCTTTGACTGACTCAGAGTAGTACTGGGTGCTACCACTTCCACTGTAAATCCAGGCAACCCATTCCAGTCCTTTTCCGGGAGCCTGTCTGATCCAGCTCATCCAGTTGCTGCTGAAGGTGAATCCAGAGGCTGTACAGGTCAATCTATGAGATTCTCCAGGCCTTTTAACCACTGGTTCAGATTCTGTCAGAGTCTG

>ighv10-1like.7 CTTTTCCAGCCCAGTAACGTTTAGTTCTGTAGGTTTTTGTACAGCTGCTCAACAACTCCAGTCACTGTGGCTCTCGAGCACAATAATAACCAGCAGAAACTTCAGTCTTCAGACTGTTCTTCTGCAGGTACACCTGCTGTCGGCTGTTGTCTCTGGAGATGGTAAACCGGCCTGTGACTGACTCAGAGTAGGAAGTGCCGCCACTAGCAGTATAGATCTCAG- 
CACGGCATTCCAGTCCTTTTCCAGGAGCCTGTCTCATCCAGTGCAAGTATTAGCTGCTGAATGTGAATCCAGAGGCTGTACAAGTCAAACTGTGAGATTCTCCAGGCCTATTAACCACTGGTTCAGATTCTGTCAGAGTCTG

>ighv10-1like.8 TCTTTCAGTCCAGTAAAGATGAGTTCTGCAGGTTTTTGTACAGCTGCTCAACAACTCAAGTCACTGTGTCTCTCGAGCACAATAATAAACAGCAGAATCTTCAGTCTTCAGACTGTTCATCTGCAGATACACCTGCTGTCTGCTGTTGTCTCTGGAGATGGTAAACCGGCCTTTGACTGACTCAGAGTAGTAGATGCTACCACTGCTATCACTGATAGTAGAAACCCACTCCAGTCCTTTTCCAGCAGCCTGTCTGATCCAAGCGTTTCCAGTAATTGCCTCCAAACCCTGAATATGTGCAGGTCAGTCTGTGGGATTCTTCAGGCCTTTTCACTGCTGATTCAGACTCAGTCAGTGTTTG

>ighv10-1like.9 GCTTCTCATATAGAGATCAGTTGTGTTCAGTTTTTGTACAGCTCTGTAGTCTGCTGTGTCACTGTGTCTCTCGAGCACAATAATAAACTGCAGAGTCTTCAGTCTTCAGACTGTTCATCTGCAGATACACCTGCTGTCTGCTGTTGTCTCTGGAATGGTAAACCGGCCTTTGACTGACTCAGAGTAGTATTTTCCTGTCATTATCATTTTCAACCCAGGCAATCCATTCCAGTCTTTTTCCAGGAGCCTGTCTGATCCAGTTCATCCCGTAGTCACTGATTGAATCCAGAGGCTGTACAGGTCAATCTGTGAGATTCTCCAGGCCTTTTAACCACTGGTTCAGATTTGTCAGAGTCTG

>ighv10-1like.10

AAAATACGTCATACTTTGGCTCTTTCAGTCCAGTAAAGATGAGTATTGTAGGTTTTTGTACAGCTGCTCAACCAACTCCAGTCACCGTGTCTCTCGAGAACAATAATAAACAGCAGAATCTTCAGTCTTCAGACTGTTCATCTGCAGATATGACTGCTGTCTGCTGTTGTCTCTGGAGATGGTAAACCGGCCTCTGACTGACTAGTAGTATTTGCTGCTGTCATCAGTGTAAGTCAAGGCGATCCACTCCAGTCCTTTTCCTTTCGCAGGAAGGATGAGGAAGGAAGGCGGAAGAAAGCAACACACTACAATCTTCCCCACCGGTCCAGAACACTTCAAGAGCTCACCTCAGGACAGAAAGTGTGGATCACCGCAGATAAAGCTCCTGGGACTGTTCT

>ighv10-1like.11 GAAAGTAAAGTTTTGACTTATTTTGACTTGTTGAGTTTTTGTATAGCGTTGCTCGTTCCTGTGTCACTGTGAGTCTCAAGCACAATAATAAACAGCAGAATCTTCAGTCTTCAGACTGTTCATCTGCAGATACACCTGCTGTCTGCCATTGTCTCTGGAGATGGTAAACCGGCCTTTGACTGACTCAGAGTAGTAGATGTAGCTACTACCATCACTGCTGATAGTAGAGACCCACTCCAGTCCTTTTCCAGCAGCCTGTCTGATCCAAGCGTTCCAGTAATTGCTACTGAACCCTGAATATGTGCAGGTCAGTCTGTGGGATTCTCCAGGCCTTTTAACTGCTGGTTCAGACTCAGTCAGTGTTTG

>ighv11-2like.1 AACTGTAAGTATTTTTCAGGCTCTTTCAGCCCAGTAAAGATGAGTTCTGTAGGTTTTTCTACAGCTGCTCAACAACTCCAGTCACTGTGGCTCTCGAGCACAATAATAAACAGCAGAATCTTCAGTCTTCAGACTGTTCATCTGCAGATACACCTGCTGTCTGCTGTTGTCTCTGGACATGGTGAAGCGATTCTGGACTGATGTGGAATAAAGTTTAGTGCTTCCACTTGGAGCAGAAATGTGAGAAACCCACTCCAGTCCTTTTCCTTCAGCTTGTCTGATCCAGCTGATATCAGCATCACCATCTGATATTCCTGCATATGTACAGGTCAGTCTGTGGGATTCTCCATGCTGCTTCACCACTGGTTCAGACTCGGTCAGAGTCTG

>ighv11-2like.2 TACTTCAACTCAGTAAAGATGAGTTCTGTAGGTTTTTGTACAGCTGCTCAACAACTCCAGTCACTGTGACTCTCGAGCACAATAATAACAGCAGAATCTTCAGTCTTCAGACTGTTCATCTGCAGATACACCTGCTGTCTGCTGTTGTCTCTGGACATGGTGAAGCGATTCTGGACTGATGTGGAATAAAGTTTAGTGCTTCCACTTGGAGCAGAAATGTGAGAAACCCACTCCAGTCCTTGTCCTTCAGCTTGTCTTCCAGCTGATATCAGCATCACCATCTGATATTCCTGCATATGTACAGGTCAGTCTGTGGGACTCTCCATGCTGCTTCACCACTGGTTCAGACTCAGTCAGAGTCTG 
182 


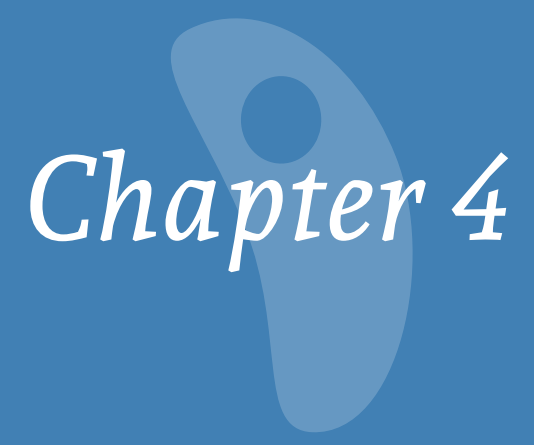

\title{
Unveiling Enteromyxum leei (Myxozoa) prophylactic and diagnostic peptides from RNAseq data
}

\author{
Amparo Picard-Sánchez; M. Carla Piazzon; \\ Ariadna Sitjà-Bobadilla; Oswaldo Palenzuela \\ INSTITUTO DE ACUICULTURA TORRE DE LA SAL \\ CONSEJO SUPERIOR DE INVESTIGACIONES CIENTÍFICAS (IATS-CSIC), \\ Torre de la Sal s/n 12595 Castellón Spain
}

(UNPUBLISHED) 
Control of enteric parasitic diseases of farmed gilthead sea bream 


\subsection{ABSTRACT}

Enteromyxum spp. are obligate parasites closely related to cnidarians. They are responsible for serious emaciative diseases in cultured marine fish worldwide. These parasites are known to develop in fish intestines, dwelling in the paracellular space among the host's enterocytes. So far, there are no in vitro culture or isolation protocols, hampering the research on treatments or vaccines against these infections. Due to the difficulties to study this parasite model, we developed a pipeline to achieve a de novo parasite transcriptome assembly from heavily infected intestinal samples containing a mix of host and parasite cells. Using a specifically developed probability scoring algorithm, the transcripts were compared with a custom database of cnidarians, myxozoans and fish, in order to separate host from parasite transcripts. This pipeline yielded a parasite transcriptome consisting of 14,325 transcripts that were subsequently used in two different approaches to find diagnostic and therapeutic parasite proteins. On the one hand, an in silico data mining of the parasite transcriptome resulted in the selection of three proteins with diagnostic potential that were used for monoclonal antibodies production. On the other hand, Western blot using parasite antigens and gilthead sea bream serum containing parasite specific antibodies was used to pinpoint and sequence parasite antigenic proteins, that were subsequently identified in the newly generated parasite transcriptome. This approach resulted in the identification of twelve vaccine candidates against enteromyxosis. The results of this work will have future applications in the production of diagnostic tests and effective vaccines to be used in aquaculture.

\section{Keywords}

Antibodies, Enteromyxum leei, parasite transcriptome, Sparus aurata, vaccine, diagnostic, peptides. 


\subsection{INTRODUCTION}

Aquaculture is increasing year-by-year reaching a production of 82 million tons (excluding aquatic plants), with a value of over 250 billion euros in 2018 (FAO, 2018). In fish farms facilities, globalization of the trade and the need to increase productivity facilitate the emergence of infectious diseases that cause important economic losses (Anderson \& May, 1979). Especially, parasite infections cause significant production losses per year (Shinn et al., 2015), posing an important problem for fish farming.

The Myxozoa clade comprises more than 2180 species spread worldwide, most of which are fish endoparasites (Lom \& Dyková, 2006). This group of parasites is responsible for important economic losses in both freshwater and marine fish production (Canning \& Okamura, 2004; Kent et al., 2001; Yokoyama, 2003) and, to date, there are not effective control measures against these infections such as vaccines or chemotherapeutics. The complete life cycle of most myxozoan species still remains unknown. However, based on a few known cycles, it is assumed that the general cycle alternates between an invertebrate and a vertebrate host, developing different types of spores and vegetative developmental stages and suffering profound morphophysiological transformations (see introduction section 2.4).

Enteromyxum leei is a histozoic myxozoan that dwells between the gut epithelial cells causing different degrees of anorexia, delayed growth with weight loss, cachexia (Diamant et al., 1994), reduced marketability and mortality (Golomazou et al., 2006; Palenzuela, 2006; Rigos \& Katharios, 2010). This myxozoan has emerged as a serious risk to cultured gilthead sea bream, Sparus aurata, among others, due to its ease in fish-to-fish transmission and its high pathogenic potential. Their typical cellwithin-cell division produces proliferative stages that are capable of releasing new cells, which can invade other areas of the host tissue (Sitjà-Bobadilla \& Palenzuela, 2012). Nowadays, E. leei constitutes a threat for many other cultured sparids, such as sharpsnout sea bream, Diplodus puntazzo (Athanassopoulou et al., 1999), common sea bream, Pagrus pagrus (Diamant, 1995), and red sea bream, Pagrus major (le Breton \& Marques, 1995). The molecular characterization of these parasites is hampered by the difficulties for its purification from host tissues. This histozoic metazoan parasite has similar cellular density to host enterocytes, a similar plasmatic membrane composition and a wide range of cell sizes along its development in the fish. Furthermore, it is known that this parasite develops pseudopods that tightly attach to surrounding enterocytes (Cuadrado et al., 2008). Thus, their separation by centrifugation, by specific lysis of host membranes, or even by flow cytometry using monoclonal antibodies, has been unsuccessful (author's unpublished data). The failure to achieve long-term in vitro cultures of Enteromyxum spp. (Redondo et al., 2003) limits the precision and calibre of research studies, which is common with 
parasites (Ahmed, 2014). Nonetheless, in vivo methods for parasite maintenance have been established for E. leei (Estensoro et al., 2010), which at least provides a continuous source of parasites for molecular assays (Estensoro et al., 2013; PérezSánchez et al., 2013; Piazzon et al., 2018).

Genomic studies in other myxosporean models face similar difficulties to separate parasites from host cells before sequencing. To some extent, this issue can be averted by separating the sequences afterwards in silico using BLAST against available databases of related organisms (Foox et al., 2015). However, quality reference data on myxozoans and related organisms is quite scarce and some available datasets are possibly contaminated with host sequences (Ahmed, 2014). In addition, at a genetic level, myxozoans are characterized by a very fast-clock evolution pace, leading to little similarity in protein-coding genes compared to their cnidarian homologs or to other organisms that are well-represented in gene databases (Chang et al., 2015, Yahalomi et al., 2017). In the current study, a new transcript screening pipeline which scored the probability for each transcript of being parasite or host, was implemented. The information obtained from this pipeline was used to pinpoint and study potential diagnostic and therapeutic targets against enteromyxosis in gilthead sea bream. From the classified parasite transcripts, candidate diagnostic peptides were selected by their predicted membrane-bound external location and high level of expression during the development in the fish. Therapeutic candidates were selected by their immunogenic properties on their gilthead sea bream host. The candidates identified in this work will serve as a basis for future studies towards the management of enteromyxosis in aquaculture facilities.

\subsection{MATERIALS AND METHODS}

\subsubsection{Parasite material}

E. leei-infected gilthead sea bream were kept in $5 \mu \mathrm{m}$-filtered and UV irradiated sea water (salinity $37.5 \mathrm{~g} / \mathrm{L}$ ) at $20^{\circ} \mathrm{C}$, with natural photoperiod at our latitude $\left(40^{\circ} 5^{\prime} \mathrm{N} ; 0^{\circ} 10^{\prime} \mathrm{E}\right)$. Infected animals were selected from the stocks maintained in the laboratory and infected by effluent exposure or anal intubation, as previously described (Estensoro et al., 2010). Infective status of the fish was assessed from intestine mucosae samples taken non-lethally using cotton swabs (Fox et al., 2000), which were tested by qPCR as previously described (Picard-Sanchez et al., 2019). The fish with the lowest cycle threshold (Ct) values were sacrificed by overexposure to anaesthesia (MS-222, $0.1 \mathrm{~g} / \mathrm{L}$; Sigma) and dissected. Intestinal mucosae scrapings from the posterior intestine were collected and then processed for RNA or protein isolation. 
All efforts were made to minimize suffering of the fish used for the experiments in accordance with national (Royal Decree RD53/2013, for the protection of animals used in scientific experiments) and the current European Union legislation (Directive 2010/63/EU) and the CSIC National Committee on Bioethics under approval number 2018/VSC/PEA/0240..

\subsubsection{Parasite de novo transcriptome}

\section{RNA isolation}

The samples for RNA extraction were processed as explained previously (PicardSánchez et al., 2019). Briefly, the intestinal scrapings were collected from infected fish and deposited in $15 \mathrm{ml}$ centrifuge tubes containing Hanks' balanced salt solution (HBSS) supplemented with an antibiotic/antimycotic mixture $(1 \times \mathrm{PSA}=100 \mathrm{U} / \mathrm{ml}$ penicillin, $100 \mu \mathrm{g} / \mathrm{ml}$ streptomycin, and $0.25 \mu \mathrm{g} / \mathrm{ml}$ amphotericin B). Infection was confirmed using a microscope at $1200 \times$ magnification. Samples richer in parasite stages were centrifuged $10 \mathrm{~min}$ at $400 \times \mathrm{g}$ and the pellet was washed twice in fresh HBSS containing $2 \times$ PSA. Immediately after, RNA was isolated using the PureLink RNA mini Kit (Ambion), following the manufacturer's instructions. Concentration and quality of RNA samples was assessed using a BioAnalyzer 2100 (Agilent). Prior to NGS sequencing, RNA samples were further screened for quality and quantity and the tissue ratio (parasite/host), in order to select the sample that had highest RNA concentration/quality and lowest quantity of host material. For that purpose, parallel tissue samples from each fish were taken for DNA extraction with silicabased column kits (Roche Diagnostics). DNA yield and quality was assessed with a NanoDrop 2000c (Thermo Scientific, Wilmington, DE, USA) and an estimate of host/parasite ratio was obtained by specific qPCR tests targeting the SSU rDNA from the parasite and the host. Two individual reactions were performed with each sample containing $100 \mathrm{ng}$ of total input DNA in a reaction volume of $20 \mu \mathrm{l}$ with PyroTaq EvaGreen qPCR Mix Plus (Cultek Molecular Bioline) and 0.45 $\mu \mathrm{M}$ of specific primers (E. leei 18S primers Fw: CTATTTGCTGCTGCCATT, Rv: CCACTTATT TCGGGATTGAT, and S. aurata 18S primers: Fw: GCATTTATCAGACCCAAAAC, Rv: ATGGTAGGCCACAGAAAGT). The PCR reaction conditions consisted of an initial step at $95^{\circ} \mathrm{C}$ for $3 \mathrm{~min}$, followed by 40 cycles of denaturation for $15 \mathrm{~s}$ at $95^{\circ} \mathrm{C}$ and annealing/extension for $60 \mathrm{~s}$ at $60^{\circ} \mathrm{C}$.

\section{RNA sequencing and transcriptome assembly}

Samples from E. leei-infected gilthead sea bream contained a mix of RNA material of the two species: S. aurata and E. leei. The best samples with the highest parasite/host ratio were used for the construction of a cDNA library using the TruSeq Stranded mRNA Sample Prep kit (Illumina, San Diego, CA), following the manufacturer's instructions, and subsequently sequenced in a HiSeq2500 sequencing platform 
(Illumina, San Diego, CA). Paired-end reads were quality filtered (quality $>30$ and $<10 \%$ of Ns in the sequence) and assembled with Trinity (Grabherr et al., 2011). The resulting assembled sequences were then processed through the bioinformatics pipeline described below. The library preparation and sequencing were outsourced to a commercial service (Macrogen Inc., Korea) and the assemblies, sorting and bioinformatics pipeline were carried out in collaboration with the Instituto Universitario de Conservación y Mejora de la Agrodiversidad Valenciana (COMAV).

\section{Transcript classification: Bioinformatic pipeline}

For de novo transcript classification, an algorithm to identify myxozoan transcripts was developed. A schematic view of this new pipeline is summarised in Figure 1. Briefly, two local databases were built, using available information of genomes/ transcriptomes from GenBank, of Cnidaria/Myxozoa and Fish databases available at the moment (Supplementary Table 1). With the exception of Ceratonova shasta (Myxozoa), which was kindly shared by Drs. Jerri Bartholomew and Stephen Atkinson (Department of Microbiology, Oregon State University, USA), all the datasets were retrieved from NCBI and in several cases, for the Myxozoan/ Cnidarian species, the raw NGS data were processed and assembled de novo.

The assembled transcripts were run through an algorithm based on nucleotide BLAST (blastn), GC percentage content, and codon use, scoring the mixed species transcripts with a value as "Fish" or "Cnidaria/Myxozoa". The blastn was performed using an E value < 1 e-20 towards the two local databases described above, and keeping only the highest score. In order to improve the prediction and to assign a probability value, the pipeline was tutored with smaller, curated datasets chosen from either taxon to register the correct and incorrect classification rates. The pipeline resulted in two probabilities associated for each transcript: the probability to belong to the Fish data set (host transcript), and the probability to belong to the Cnidaria/Myxozoa data set (parasite transcript). A cut-off of $99 \%$ of probability ( $p$ ) to belong to a given group was established, and three groups of transcripts were set: sequences that had a $p>99 \%$ of being Fish; sequences that had $p>99 \%$ of being Cnidaria/Myxozoa; and the Grey Zone, sequences with not enough evidence to be classified in Fish nor Cnidaria/Myxozoa transcriptome $(p<99 \%$ of being either Fish or Cnidaria/Myxozoa). 
De novo assembled sequences

Mixed sample: Sparus aurata and Enteromyxum leei transcripts 155192 transcripts

NEW PIPELINE

- Blastn (Cnidaria/Myxozoa \& Fish databases)

- CG percentage content

- Codon use

ASSIGNMENT FOR EACH TRANSCRIPT

Probability to belong to Fish database

Probability to belong to Cnidaria/Myxozoa database

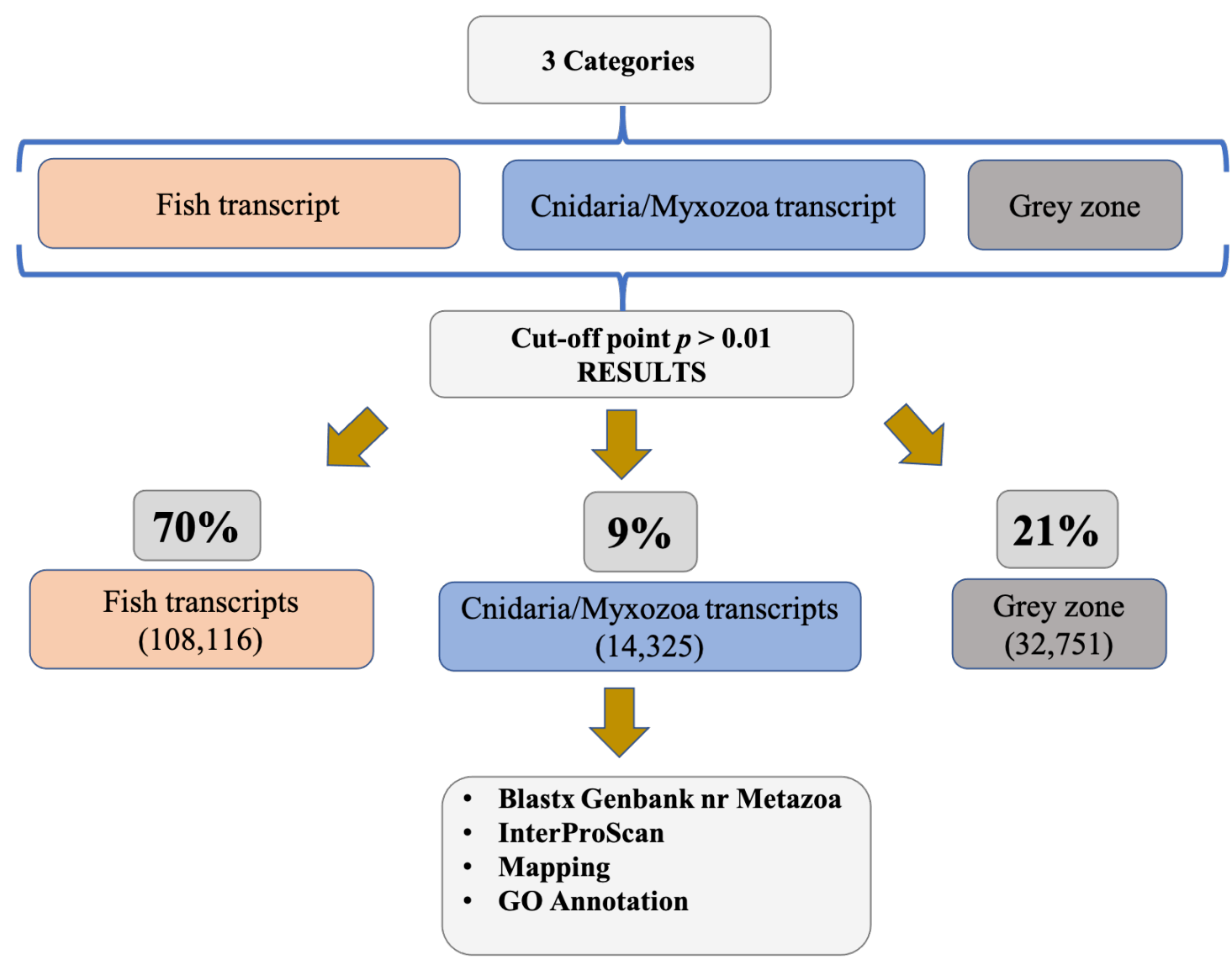

Figure 1. Schematic view of the new pipeline to classify a mixed RNA sample. Our initial sample consisted in RNA from Enteromyxum leei-infected intestine of gilthead sea bream (Sparus aurata). An in silico classification based on probabilities performing blastn, CG\% and codon use, resulted in three categories: Fish transcripts $(p>$ 0.99) Cnidaria/Myxozoa transcripts $(p>0.99$ ), and Grey zone (with $p<0.99$ to be classified as either category). Only Cnidaria/Myxozoa transcripts were further analyzed with Blast2GO (Blastx Genbank; InterProScan; Mapping; GO Annotation). 
During the classification efforts described above, a similar pipeline to classify myxozoan transcripts from host-contaminated datasets was published by Foox et al. (2015), which resulted in a highly curated list of transcripts for the myxozoan Myxobolus pendula. This dataset was then used to recover transcripts producing high blast scores against it, and therefore possibly misclassified as 'Fish' and 'Grey Zone', which were transferred to the E. leei transcriptome dataset. The retrieved sequences were double-checked by BLAST against the recently published $S$. aurata genome (Pérez-Sánchez et al., 2019). This last step served to ensure that no fish sequences were misclassified in the parasite or grey zone groups.

\subsubsection{Search for transcripts with diagnostic potential}

\section{Criteria and software}

Transcripts classified as E. leei were run through Blast2GO (Conesa et al., 2005) for further characterization and annotation. The dataset was analysed for protein domains using InterPro ID (Mitchell et al., 2019), and transcripts containing a signal peptide were selected. The transcripts were translated to proteins and further analysed by online prediction tools: SignalP-5.0 Server (Nielsen et al., 2019), SMART (Letunic \& Bork, 2018), and WoLF PSORT (Protein Subcellular Localization Prediction) (Horton et al., 2007). The transcripts were shortlisted according to these results and to the relative abundance in the original transcriptome assembly. As a result, seven transcripts which were among the $12.28 \%$ most expressed (cut-off $>5.7$ FPKM, 3.48 TPM, and 1024 expected counts), contained a signal-P sequence, were predicted to be externally located (in intermembrane domains or secreted), held known functional protein domains, and shared domains with other myxozoan species, were selected. As these transcripts were de novo assembled, the presence of known functional protein domains was a key step to ensure that a transcript is real and not an artefact of the assembly. Parasite transcripts holding conserved domains with host transcripts were excluded in order to avoid cross-reactivity of the antibodies and ensure specificity.

\subsubsection{Recombinant proteins, mice immunizations and monoclonal antibodies production}

This part of the study was performed in collaboration with INGENASA (Eurofins Technologies, Madrid), as an industrial partner in the project ParaFishControl. Three transcripts fulfilling the above explained criteria and with the highest expression levels were chosen (TG-1, TG-5 and TG-6) to synthesize selected antigenic portions as recombinant peptides, in order to produce specific mice monoclonal antibodies for immunochromatographic quick diagnostic tests. 
Prior to recombinant production, these peptides were re-checked to discard misclassification or sequencing errors by cloning their encoding mRNA from $E$. leei infected intestinal samples. Briefly, specific primers were designed to amplify the entire ORF of the proteins (Supplementary Table 2) and PCR was conducted in cDNA libraries from infected and control intestines. Control intestines did not yield any amplification product. PCR products from the entire ORF were cloned in competent E. coli using the TOPO TA vector (TOPO TA Cloning kit, Invitrogen), and re-sequenced.

Two mice immunization attempts were performed (Figure 2). In the first attempt, three different conjugated synthetic peptides from TG-1 and TG-5 were produced in E. coli. The synthetic peptides corresponded to regions of the proteins predicted to be exposed when the protein is natively folded, thus presenting antigenic potential. A 29 amino acid (aa)-long peptide form TG-1 was conjugated with ovoalbumin (OVA) as a carrier, and two different 22 aa-long peptides from TG-5 were conjugated with the carrier keyhole Limpet hemocyanin (KLH). In the second attempt, five different peptides were produced in E. coli and Baculovirus systems. A 29 aa-long peptide from TG-1 was expressed one time with a SUMO-tag (to boost expression) or in a tandem repeat (to increase the immunogenic potential); a 44 aa-long peptide from TG-5 was expressed alone or with the SUMO-tag; and a 26 aa-long peptide from TG-6 was expressed alone. All recombinant proteins were tagged with a histidine tag $(6 \times$ His-tag) to allow purification.

These recombinant peptides were injected in 4 different BALB/c mice each. Immunizations were performed by 3 intraperitoneal injections of recombinant peptide $(15-50 \mu \mathrm{g})$ with Freund's adjuvant, in a total volume of $150 \mu \mathrm{l}$ in 2 weeks intervals (Figure 2). Seven days prior to the last immunization, serum form each mouse was checked by ELISA, Western blot and immunohistochemistry (IHC). Conditions of ELISA and Western blot were adaptations from previously described protocols by Sastre et al. (2011). The polyclonal mice serum was tested against the peptide used as immunogen and against the peptide coupled to a different carrier, to consider the specific antibody response against the peptide versus the carrier. IHC, was performed on parasite infected intestinal tissue, following the protocol described in Picard-Sánchez et al. 2019, adapted for mouse antibody detection (Anti-Mouse IgG whole molecule-avidin biotin complex, Vectastain ELITE ABC Kit). Since no purified parasite was available, every test was carried out in parallel with an uninfected gilthead sea bream intestinal tissue as a control. Mice with the highest Ig titres against E. leei were chosen for hybridoma generation and monoclonal antibodies (Mabs) collection. Mabs were checked following the same protocols used for mice sera. 


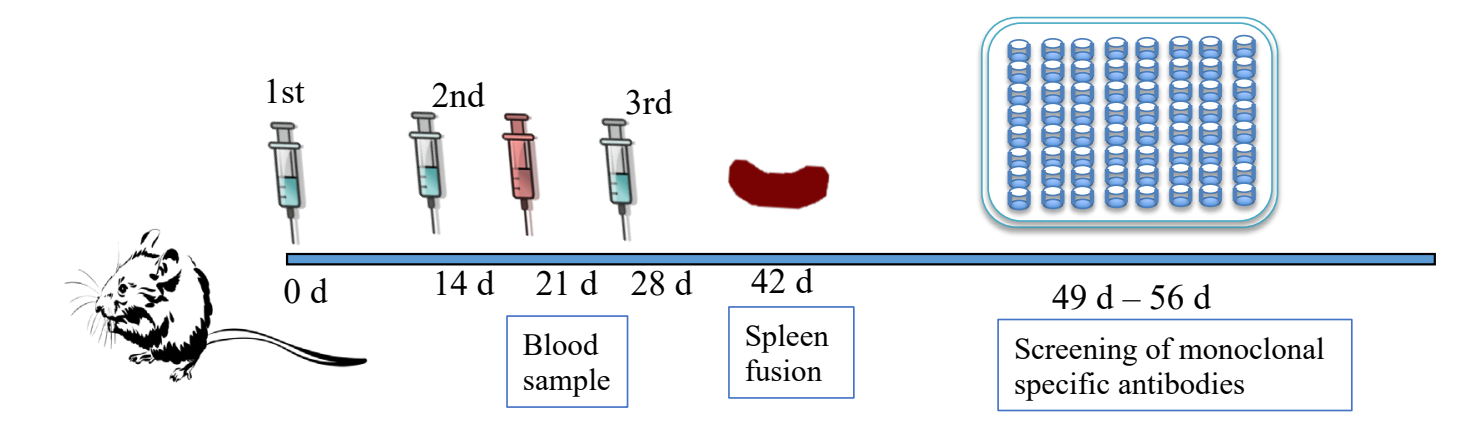

\begin{tabular}{|c|c|c|c|c|}
\hline Attempt & Target & Length of target peptide & Conjugated peptide & Recombinant protein \\
\hline \multirow{3}{*}{1} & TG-1 & 29 aа & OVA-TG-1 & - \\
\hline & TG-5 & 22 aa (pept1) & KLH-TG-5A & - \\
\hline & TG-5 & 22 aa (pept2) & KLH-TG-5B & - \\
\hline \multirow{5}{*}{2} & TG-1 & $\begin{array}{c}\text { His-SUMO(100aa)- } \\
29 a a\end{array}$ & - & His-SUMO-TG-1 \\
\hline & TG-1 & His-29aa-29aа & - & His-TG1-1repeat \\
\hline & TG-5 & $\begin{array}{c}\text { His-SUMO(100aa)- } \\
44 a \mathrm{a}\end{array}$ & - & His-SUMO-TG5 \\
\hline & TG-5 & His-44aa & - & His-TG5 (secreted) \\
\hline & TG-6 & His-26aa & - & His-TG6 (secreted) \\
\hline
\end{tabular}

Figure 2. Schematic view of immunization assays from Enteromyxum leei synthetic peptides in mice.

\subsubsection{Search for vaccine candidates}

\section{Protein samples and Western blot}

Parasite-enriched samples were obtained from intestinal scrapings of heavily infected fish. The scrapings were mixed with 1:1 (v/v) with RIPA buffer $(50 \mathrm{mM}$ Tris-HCl pH 7.5, $1 \%$ nonyl phenoxypolyethoxylethanol (NP-40), $0.5 \%$ sodium deoxycholate, $0.1 \%$ SDS, $150 \mathrm{mM} \mathrm{NaCl}, 5 \mathrm{mM}$ EDTA and $10 \mu \mathrm{l} / \mathrm{ml}$ protease inhibitor cocktail (Sigma)), and lysed in Lysing Matrix D tubes (MP Biomedicals) using a FastPrep-24 homogenizer (MP Biomedicals) with 2 cycles of $30 \mathrm{~s}$ at $6 \mathrm{~m} / \mathrm{s}$. The samples were then centrifuged at $10,000 \times \mathrm{g}$ at $4^{\circ} \mathrm{C}$ for $5 \mathrm{~min}$, and the supernatant was kept at $-80^{\circ} \mathrm{C}$ until its use. The same procedure was followed with intestinal scrapings of healthy fish to be used as negative controls.

Parasite and negative control protein samples $(20 \mu \mathrm{g})$ were denatured at $95^{\circ} \mathrm{C}$ during 5 min in $4 \times$ Laemmli sample buffer containing $\beta$-mercaptoethanol and resolved on $8 \%$ and $10 \%$ SDS-PAGE gels, in triplicate. A portion of each gel, containing one replicate of each sample, was stained with Coomassie blue and stored until band 
selection and sequencing. The other two portions with the other replicates were transferred to nitrocellulose membranes (BioRad) using a Trans-Blot SD Transfer Cell (BioRad), at $15 \mathrm{~V}$ for $30 \mathrm{~min}$. The membranes were used to perform westernblot analyses with gilthead sea bream serum with and without $E$. leei specific antibodies (Picard-Sánchez et al., 2019). Briefly, a blocking incubation step was carried out with $5 \%$ skimmed milk in Tris buffered saline $(20 \mathrm{mM}$ Tris- $\mathrm{HCl}, 0.5 \mathrm{M}$ $\mathrm{NaCl}, \mathrm{pH} 7.2, \mathrm{TBS}$ ) for $1 \mathrm{~h}$, and then membranes were incubated with fish serum known to contain parasite specific antibodies (diluted 1:25 in TBS containing 1\% skimmed milk) for $1 \mathrm{~h}$. After washing, membranes were incubated with a custommade rabbit polyclonal antibody $(\mathrm{Ab})$ against gilthead sea bream IgM (1:80,000 in TBS with 1\% skimmed milk) (Palenzuela et al., 1996) for 1 hour, washed again and incubated with a peroxidase-conjugated goat anti-rabbit IgG (Anti-Rabbit IgG whole molecule-Peroxidase antibody, Sigma) diluted 1:2000 in TBS with 1\% skimmed milk, for 1 hour. After the final washing step, bands were visualized by chemiluminescence detection with Clarity ${ }^{\mathrm{TM}}$ Western ECL substrate (BioRad) in an Amersham Imager 600 (GE Healthcare). All washing steps consisted on two successive washings for 5 min with TTBS (TBS with $0.05 \%$ Tween 20) and two 5 min washings with TBS. All the incubations were performed at room temperature. The position of specific bands recognized by the gilthead sea bream serum containing parasite-specific antibodies and not present in the negative control lanes was identified and these bands were retrieved from the stored unstained gel portions, using the Comassie-stained replicates as a reference. The bands were sequenced by mass spectrometry by the Proteomic Department of Universitat de València (SCSIE, UV, Spain).

\section{Characterization of sequenced peptides}

Sequenced peptides were searched in the de novo generated parasite transcriptome and the gilthead sea bream genome (Pérez-Sánchez et al., 2019) resulting in a list of 12 candidate parasite proteins. Characterization of the transcripts was done with the same prediction programs as previously described in section 4.2.3.

\subsection{RESULTS}

\subsubsection{Sequencing and assembly results}

The best host/parasite ratio (18S S. aurata: $18 \mathrm{~S}$ E. leei) obtained was 1.2. After Illumina sequencing, a total of $150,654,838$ paired 125 bp reads were obtained. The graphic from the raw data sequencing showed two peaks, at 30-33\% and 50-60\% of CG content (Figure 3), suggesting different average CG\% content in parasite and host transcripts. After assembling, the total number of sequences was 203,108. Quality filtering and post-processing yielded a total of 155,192 high-quality unique 
transcripts representing the E. leei transcriptome at trophozoite and spore stages, mixed with the $S$. aurata transcripts from the accompanying intestine cells. The size of the smallest transcript such that $50 \%$ of the length of this transcriptome is contained in transcripts of this size or greater (N50) was 2,358 bp, and the N95 was $296 \mathrm{bp}$. The average size of the library fragments was 1,206 bp ( $\max .19,797 \mathrm{bp}$; min. $201 \mathrm{bp}$ ) (Table 1).

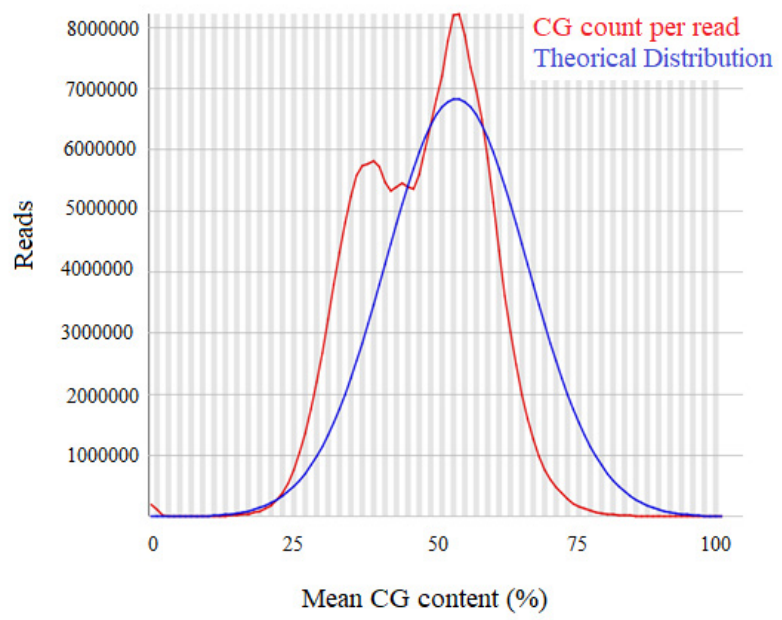

Figure 3. Diagram of CG\% content from the reads sequenced from a mixed sample of Sparus aurata and Enteromyxum leei.

Table 1. Assembly and classification results from a mixed sample of Sparus aurata and Enteromyxum leei.

\begin{tabular}{|c|c|c|c|c|}
\hline \multicolumn{5}{|c|}{ Mix of transcripts (E. leei + S. aurata) } \\
\hline \multicolumn{2}{|c|}{ Assembly by Trinity } & \multicolumn{3}{|c|}{ In silico pipeline } \\
\hline Total sequences & 203,108 & & Transcripts & CG\% \\
\hline $\begin{array}{l}\text { Post-processed } \\
\text { unique } \\
\text { sequences }\end{array}$ & 155,192 & $\begin{array}{c}\text { Cnidaria/Myxozoa } \\
(p>99 \%)\end{array}$ & 14,325 & $31.1 \%$ \\
\hline N50 (bp) & 2358 & Fish $(p>99 \%)$ & 108,116 & $48.6 \%$ \\
\hline N95 (bp) & 296 & Grey Zone & 32,751 & $40 \%$ \\
\hline Minimum (bp) & 201 & & & \\
\hline Maximum (bp) & 19,797 & & & \\
\hline Average (bp) & 1206.03 & & & \\
\hline
\end{tabular}

\subsubsection{De novo transcriptome classification. A new pipeline}

Results in terms of number of classified transcripts from the classification workflow are summarized in Figure 4A. After passing through the pipeline and setting the cutoff point at $99 \%$ of probability, the de novo assembled transcriptome $(155,192$ transcripts), yielded $9 \%$ of Cnidaria/Myxozoa transcripts (14,325 transcripts), $70 \%$ 
of Fish transcripts (108,116 transcripts); and 21\% of unclassified transcripts (Grey zone) (32,751 transcripts).

A

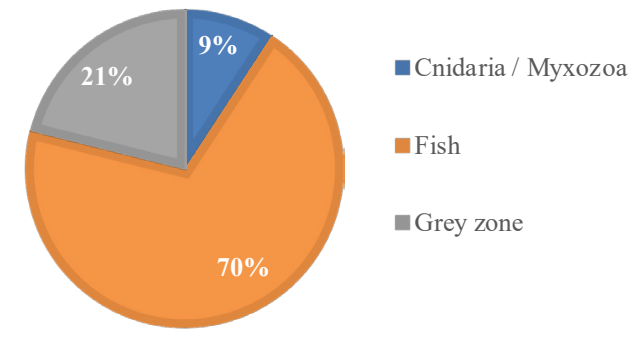

B

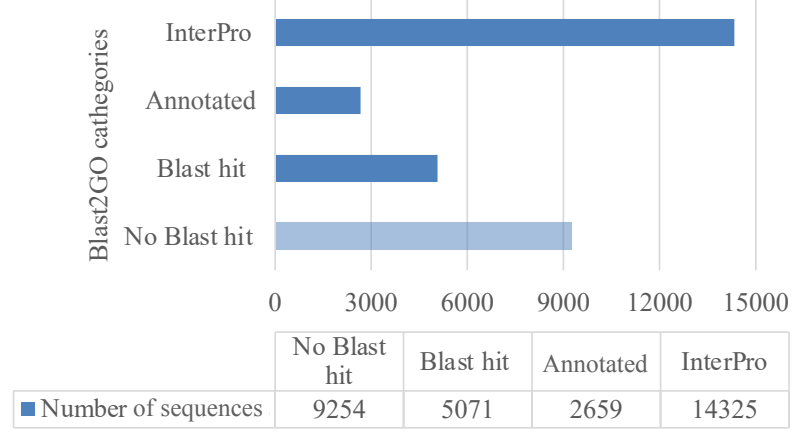

Figure 4. Classification results from mixed simple from Sparus aurata and Enteromyxum leei (A) through the sorting pipeline, and posterior analysis of Cnidaria/Myxozoa transcripts using Blast2GO (B).

\subsubsection{De novo transcriptome functional annotation}

Blast2GO analyses were performed using the 14,325 myxozoan transcripts. The results showed that using BLAST against the non-redundant database of NCBI, $35.4 \%$ of the sequences had a significant blast hit, and $64.6 \%$ of sequences did not show any blast hit (unknown) (Figure 4B). From the sequences with BLAST hit, $52.44 \%$ were annotated and assigned GO categories. Figure 5 shows the percentage of the different GO terms divided in three primary categories: Celullar component, Biological process, and Molecular function. The most representative categories in Cellular component GO terms, membrane (17\%), nucleus (16\%), and cytoplasm (14\%) were the most represented, whereas, plasma membrane (6\%) and extracellular (6\%) were amongst the least represented (Figure 5A). In Molecular function GO terms, protein binding (25\%), and binding (20\%) were the most abundant (Figure 5B). Finally, in Biological process GO terms were 'single organism cellular process' (19\%), 'regulation of cellular process' (11\%), and 'cellular process' (11\%) (Figure 5C). 

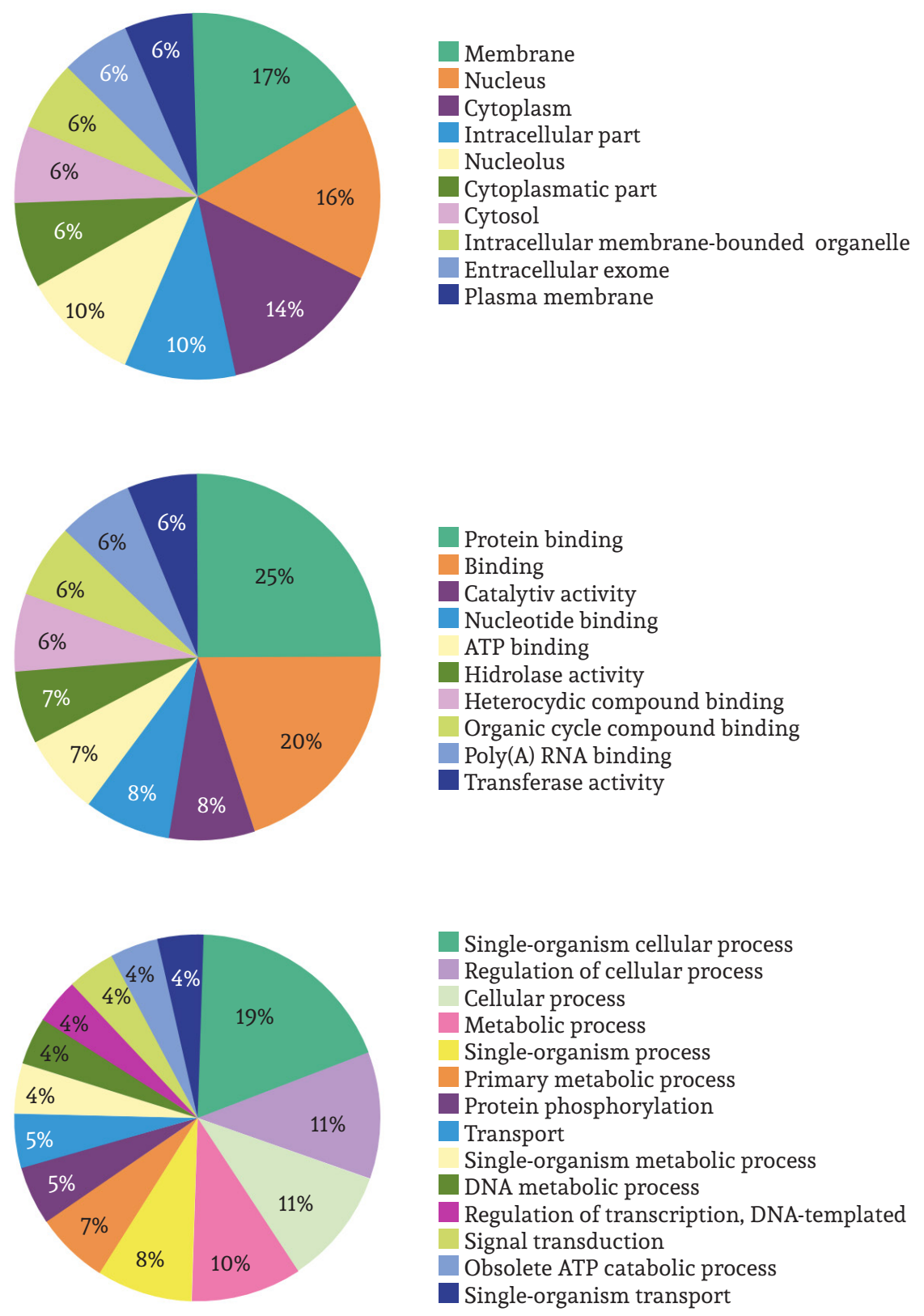

Single-organism cellular process

Regulation of cellular process

Cellular process

Metabolic process

Single-organism process

Primary metabolic process

Protein phosphorylation

Transport

Single-organism metabolic process

DNA metabolic process

Regulation of transcription, DNA-templated

Signal transduction

Obsolete ATP catabolic process

Single-organism transport

Figure 5. Gene Ontology (GO) analysis of the Cnidaria/Myxozoa transcripts. The percentage and distribution of top-level GO-terms were portrayed in the three categories: Cellular component (A); Molecular function (B) and Biological process (C).

Additionally, a BLASTx (e_val < $\left.10^{-5}\right)$ was performed against the available myxozoan genomes and transcriptomes (Supplementary Table 1) using the annotated and unknown E. leei sequences identified with our pipeline (Supplementary Table 3). As expected, the most similar species was E. scophthalmi, with more than $90 \%$ of the annotated and unknown sequences similar. Unknown transcripts did not yield similarities with any other myxozoan species, whereas annotated transcripts showed that the next more similar species was C. shasta (92\%), followed by K. iwatai (89\%). 


\subsubsection{Transcripts with diagnostic potential}

Through Blast2GO InterPro annotation, 3.18\% of the Cnidaria/Myxozoa transcripts were predicted to code a signal peptide (456 out of 14,325 transcripts). Further analysis with prediction tools following the parameters described in the methods section (external location, high expression, transmembrane domains (TM), etc.) resulted in the selection of seven candidate transcripts. These candidates were among the top $12 \%$ most expressed in E. leei, they contained a signal-P domain, which means that they can either be secreted or inserted in cellular membranes, and $57.14 \%$ (4 out of 7) had transmembrane domains, which may indicate that they are anchored to the membrane and present regions protruding into and out of the cells. Moreover, all of them showed homology with at least one transcript from $E$. scophthalmi, which is the closest myxozoan to E. leei known so far. Further details of the candidates can be found in Table 2.

Table 2. Features of the seven in silico selected diagnostic candidates against Enteromyxum leei.

\begin{tabular}{c|c|c|c|c|c|c|c|c} 
Candidate & $\begin{array}{l}\text { Effective } \\
\text { length } \\
\text { (nt) }\end{array}$ & $\begin{array}{l}\text { Peptide } \\
\text { length } \\
\text { (aa) }\end{array}$ & $\begin{array}{l}\text { Expected } \\
\text { count }\end{array}$ & TPM & FPKM & Signal-P & $\begin{array}{l}\text { Probability } \\
\text { of Signal-P }\end{array}$ & $\begin{array}{l}\text { SMART } \\
\text { Domains }\end{array}$ \\
\hline TG-1 & 663 & 220 & 2288 & 22.29 & 36.33 & Yes & $50 \%$ & SP + TM \\
\hline TG-2 & 663 & 220 & 454 & 0.51 & 0.84 & Yes & $91.7 \%$ & $\begin{array}{c}\text { SP + TM + } \\
\text { LCR }\end{array}$ \\
\hline TG-3 & 639 & 212 & 1795 & 21.51 & 35.07 & Yes & $30 \%$ & SP + Sh_KT \\
\hline TG-4 & 960 & 319 & 1931 & 7.25 & 11.82 & Yes & $87 \%$ & SP + LCR \\
\hline TG-5 & 1155 & 384 & 1024 & 3.48 & 5.67 & Yes & $92 \%$ & SP + LCR \\
\hline TG-6 & 879 & 292 & 2804 & 7.58 & 12.36 & Yes & $98 \%$ & SP + LCR + \\
\hline TG-7 & 1524 & 507 & 4296 & 10.94 & 17.84 & Yes & $86 \%$ & SP + 7_TM \\
\hline
\end{tabular}

Effective length: number of nucleotides of transcript full ORF; Peptide length: number of amino acids predicted from the full ORF; TPM: Transcripts Per Kilobase Million; FPKM: Fragments Per Kilobase Million. SMART Domains abbreviations: SP, signal peptide; TM, transmembrane motive; LCR, low complexity region, Sh_KT, ShK toxin domain. Programs used: Expasy (translation), SignalP 4.0 Server and SMART (Signal P information), SMART.

The results of the immunization attempts are summarised in Table 3. In the first attempt, one peptide from candidate TG-1 (conjugated with OVA, TG-1) and two different peptides from candidate TG-5 (conjugated with KLH, TG-5A and TG-5B) were injected in four mice each and the polyclonal sera were obtained. Negative controls (mice immunized with unrelated peptides and same protein carriers were also produced and tested). Most of the polyclonal sera showed nonspecific signal in ELISA and western blot. In IHC, noise or background signals with the fish epithelium and weak staining of the parasites was frequently observed (Figure 6D, E). However, the sera from two mice immunized with peptide KLH-TG-5A produced clear specific IHC staining against E. leei (Figure 6A, B). Both sera also showed a spe- 
cific signal in ELISA and western blot assays, thus, the two mice were selected for cell fusion and monoclonal antibody (Mab) production. The Mabs from the resulting hybridomas were screened and analysed by ELISA against the TG-5A peptide coupled to the alternative carrier (OVA).
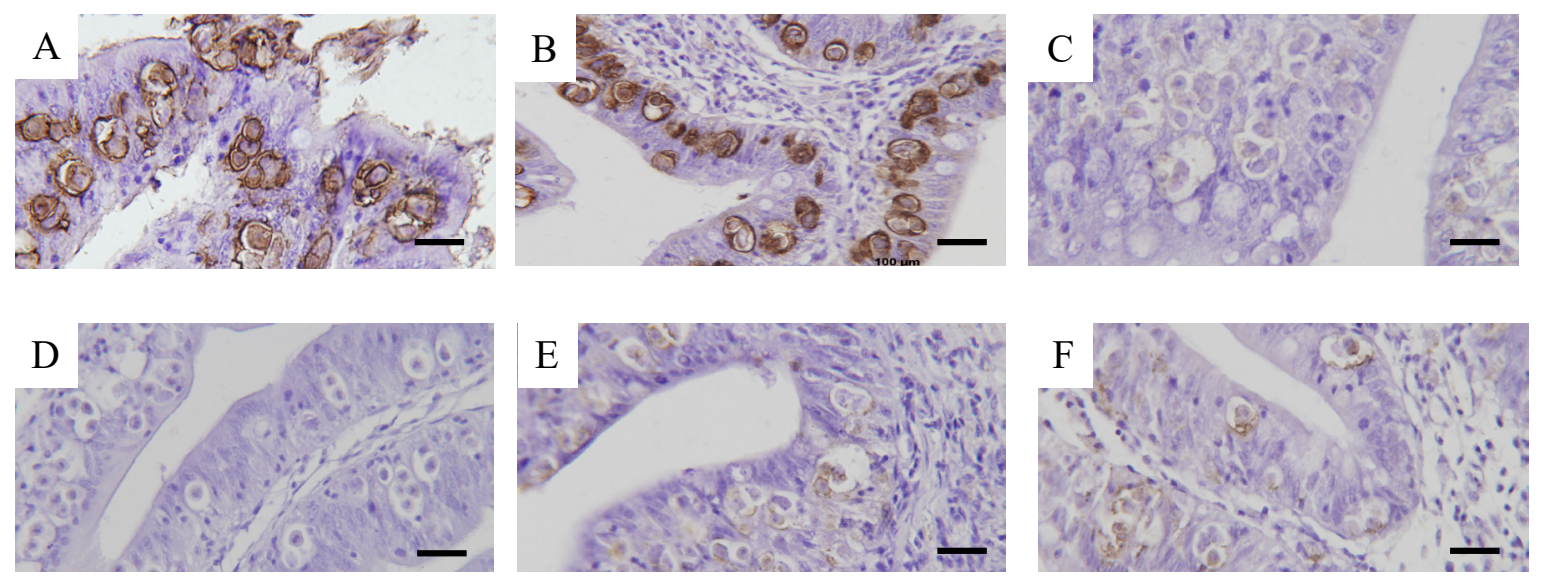

Figure 6. Representative pictures of the immunohistochemistry assays. Samples of gilthead sea bream's intestine used to test sera from mice immunized with the target proteins from Enteromyxum leei bound to KLH (A-C) or OVA (D-F) carriers. Mice serum immunized with KLH-TG-5A (A, B), mice serum immunized with OVA-TG-1 (D, E), and control mice serum immunized with the carrier alone (KLH, C; OVA, F).

Table 3. Summary of the two immunization trials undertaken to produce diagnostic antibodies against Enteromyxum leei.

\begin{tabular}{l|l|l|l|l|l|l|l|l} 
& \multicolumn{3}{|l}{ Immunization Trial 1 } & \multicolumn{7}{l}{ Immunization Trial 2 } \\
\hline Candidates & TG1 & TG5 & TG5 & TG1 & TG1 & TG5 & TG5 & TG6 \\
\hline Immunogen & $\begin{array}{l}\text { OVA- } \\
\text { TG1 }\end{array}$ & $\begin{array}{l}\text { KLH- } \\
\text { TG5A }\end{array}$ & $\begin{array}{l}\text { KLH- } \\
\text { TG5B }\end{array}$ & $\begin{array}{l}\text { His-SUMO- } \\
\text { TG1 }\end{array}$ & $\begin{array}{l}\text { His-TG1- } \\
\text { TG1 }\end{array}$ & $\begin{array}{l}\text { His-SUMO- } \\
\text { TG5A }\end{array}$ & $\begin{array}{l}\text { His- } \\
\text { TG5A }\end{array}$ & His-TG6 \\
\hline $\begin{array}{l}\text { No. of } \\
\text { immunized } \\
\text { mice }\end{array}$ & 4 & 4 & 4 & 4 & 4 & 2 & 3 & 4 \\
\hline ELISA & NSS & SS & NSS & NSS & NSS & NSS & NSS & NSS \\
\hline WB & NSS & SS & NSS & Strong NSS & SS? & Strong NSS & SS? & SS? \\
\hline IHC & NSS & SS & NSS & - & $\begin{array}{l}\text { Moderate } \\
\text { SS }\end{array}$ & - & $\begin{array}{l}\text { Variable } \\
\text { SS }\end{array}$ & $\begin{array}{l}\text { Variable } \\
\text { SS }\end{array}$ \\
\hline $\begin{array}{l}\text { Spleen } \\
\text { fusion }\end{array}$ & - & 2 & - & - & $\begin{array}{l}\text { In } \\
\text { progress }\end{array}$ & - & 2 mice & 2 mice \\
\hline
\end{tabular}

Enzyme-linked immunosorbent assay (ELISA), western blot (WB) and immunohistochemistry (IHC) were performed against parasite samples to test the specificity of the polyclonal sera. NSS: no specific signal, SS: specific signal. Question marks (?) refer to unclear or weak signals.

The first attempt resulted in 4 Mabs (characterized as IgG): T5B\#22D12, T5B\#31F1, T5B\#32B11, and T5B\#33B1. The subsequent characterization of these by Western blot, ELISA and IHC showed nonspecific or very weak reactivity against the parasite 
samples or the peptides produced for mice immunization. Troubleshooting of the signals and technical verification of the assays was conducted, and appropriate controls were included (rabbit polyclonal against E. leei, mouse polyclonal serum of the parental mice and negative controls). Further analysis of the control assays revealed that most of the signal derived from nonspecific reactions with the KLH carrier.

In the second attempt, the polyclonal sera from mice immunized with SUMOtag containing proteins (TG-1-SUMO and TG-5-SUMO, Figure 6) showed a strong unspecific reactivity in ELISA and western blot, as it was observed either in protein extracts containing or not parasites. This was interpreted as an antibody response against the SUMO tag, causing cross-reactivity with fish SUMO-homologues (Table 3). Besides, SUMO-tag cleavage and further purification of the cleaved fragment was not optimal during the synthesis (tandem structure occasionally caused protein fragmentation), thus no further efforts were addressed on that direction. Instead, an additional expression construct containing only the Histidine tag (His-tag) for peptides from TG-1, TG-5 and TG-6 was made. Besides, a peptide from TG-1 was redesigned using a tandem repeat of the initial peptide (His-(TG-1)-(TG-1)) (Figure 6).

The mice polyclonal serum from His-TG-5 and His-TG-6 constructs showed moderately specific signals against $E$. leei in IHC with variations among the individual serum tested. The reactivity by Western-blot against specific proteins present in the parasitized intestinal extracts was also variable with different sera and intestinal extract batches used, and nonspecific signal was detected in ELISA. From His-TG-5, His-TG-6, two mice with the best specific signal from the combined screening criteria were chosen for Mab production (Table 3). A total of 10 Mabs were produced against TG-5A and 12 Mabs against TG-6. Characterization of these Mabs, showed a generally weak signal in IHC, with slight differences among clones, but without specific bands in Western blot nor specific signal in ELISA (data not shown).

The mice polyclonal serum against the redesigned His-TG-1-TG-1 repeat showed moderate reactivity against the parasite and minor differences among sera by IHC. By western-blot, a band of a molecular weight close to the putative parasite protein was observed in one serum pre-selected by IHC reactivity, and this mouse was selected for Mab development. Screening of these Mabs is still in progress. 


\subsubsection{Therapeutic transcripts}

Positive bands from the Western blot (Figure 7), labelled by antibodies present in the serum of previously infected and recovered fish, were sequenced by tandem mass spectrometry (MS/MS). The sequences obtained were searched in the parasite transcriptome database, resulting in a list of 12 matching candidate peptides (Table 4). Characterization of the transcripts was done with the same prediction programs as previously explained (Expasy, SMART, Signal P predictor, etc.). From the 12 peptides, five (41.7\%) were annotated transcripts from the Cnidaria/ Myxozoa database generated (Table 4). Attending to the putative subcellular location, inferred from the Wolf prediction tool, four out of 12 transcripts (33.3\%) had high probabilities of being extracellular or anchored at the plasma membrane (candidates 4, 5, 11, and 12). However, only two had a predicted signal peptide in their sequence (candidates 5 and 11).

The rest of the candidates (66.7\%) were predicted at intracellular locations, such as peroxisomes, mitochondria or nucleus. Further steps will be addressed to produce recombinant proteins with the candidates with the highest probability of being externally located and membrane-bound (candidate 5, and candidate 11), in an attempt to test them as suitable candidates for a recombinant vaccine against $E$. leei.

A

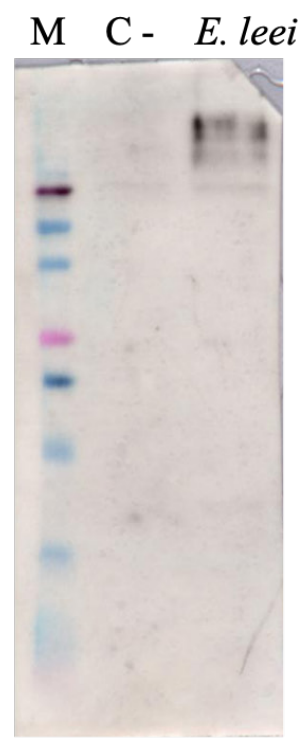

$16 \%$ Acrylamide

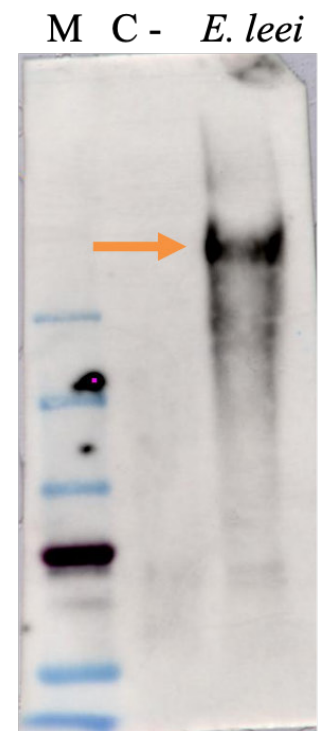

$8 \%$ Acrylamide
B

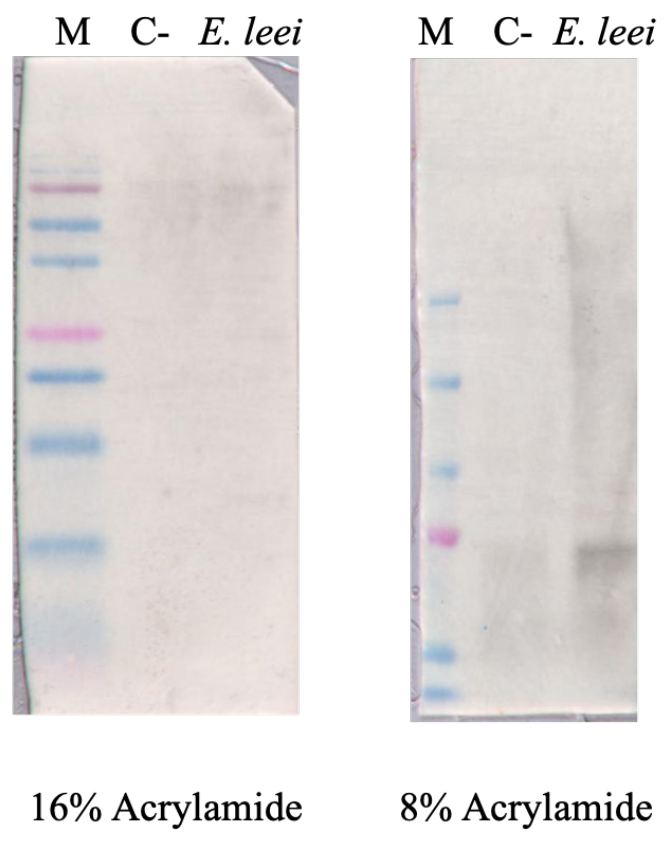

Figure 7. Western blot of healthy intestines and Enteromyxum leei-infected intestines of gilthead sea bream, incubated rather with Enteromyxum leei-resistant fish serum (A) or NAI fish serum (B). Resolving was performed in two different concentrations of acrylamide ( $8 \%$ and $16 \%)$. The orange arrow points to the band that was sequenced (A). $\mathrm{M}=$ molecular weight marker; $\mathrm{C}$ - = healthy intestinal sample of gilthead sea bream; $E$. leei $=E$. leei-infected intestines of gilthead sea bream. 
Table 4. Features of the selected candidates labelled by serum from resistant gilthead sea bream (with specific antibodies against Enteromyxum leei) in a Western blot, and sequenced.

\begin{tabular}{|c|c|c|c|c|c|c|c|c|}
\hline $\begin{array}{l}\text { Candi- } \\
\text { date }\end{array}$ & $\begin{array}{l}\text { Annotated } \\
\text { protein }\end{array}$ & $\begin{array}{l}\text { Peptide } \\
\text { length } \\
\text { (aa) }\end{array}$ & $\begin{array}{l}\text { Expected } \\
\text { count }\end{array}$ & TPM & FPKM & Signal-P & $\begin{array}{l}\text { Proba- } \\
\text { bility } \\
\text { signal P }\end{array}$ & $\begin{array}{l}\text { SMART Do- } \\
\text { mains }\end{array}$ \\
\hline 1 & annexin a7 & 294 & 41863 & 170.74 & 278.34 & No & $0 \%$ & $\begin{array}{l}\text { 2_ANX + } \\
\text { 2_LCR }\end{array}$ \\
\hline 2 & $\begin{array}{l}\text { protein-glutamine } \\
\text { gamma- } \\
\text { glutamyltransferase } \\
4\end{array}$ & 579 & 61526 & 127.61 & 208.03 & No & $0 \%$ & $\begin{array}{l}\text { Transglut_N + } \\
\text { TGc + LCR }\end{array}$ \\
\hline 3 & NA & 477 & 1058 & 2.67 & 4.35 & No & $0 \%$ & 4_LCR \\
\hline 4 & NA & 135 & 4325 & 38.54 & 62.82 & No & $0 \%$ & 1_TM \\
\hline 5 & NA & 580 & 61526 & 127.61 & 208.03 & Yes & $85.5 \%$ & $\begin{array}{l}\text { RPT1 + 2_FN3 } \\
+ \text { LCR + TM }\end{array}$ \\
\hline 6 & NA & 388 & 652 & 2.02 & 3.3 & No & $0 \%$ & $\mathrm{LCR}+3 \_\mathrm{CCR}$ \\
\hline 7 & $\begin{array}{l}5 \text {-nucleotidase } \\
\text { domain-containing } \\
\text { protein 2-like }\end{array}$ & 468 & 997 & 2.56 & 4.17 & No & $0 \%$ & 5_nucleotid \\
\hline 8 & NA & 59 & 7 & 0.14 & 0.23 & No & $0 \%$ & - \\
\hline 9 & $\begin{array}{l}\text { low affinity } \\
\text { cationic amino acid } \\
\text { transporter } 2 \text {-like }\end{array}$ & 786 & 5031 & 7.7 & 12.55 & No & $0 \%$ & ? \\
\hline 10 & $\begin{array}{l}\text { atp synthase } \\
\text { subunit } \\
\text { mitochondrial-like }\end{array}$ & 169 & 13364 & 94.79 & 154.53 & No & $0 \%$ & $\begin{array}{l}\text { ATP-synt_ab_ } \\
\text { Ndomain }+ \\
\text { LCR }\end{array}$ \\
\hline 11 & NA & 94 & 143 & 1.82 & 2.97 & Yes & $95.2 \%$ & SP \\
\hline 12 & NA & 132 & 23 & 0.21 & 0.34 & No & $0 \%$ & $-E$ \\
\hline
\end{tabular}

Effective length: number of nucleotides of transcript full ORF; Peptide length: number of amino acids predicted from the full ORF; TPM: Transcripts Per Kilobase Million; FPKM: Fragments Per Kilobase Million. SMART Domains abbreviations: ANX, Anexin; Transglut_N Transglutaminase/protease-like homologues; TGc, Protein-glutamine gamma-glutamyl transferases; RPT1, Internal repeat domains; FN3, Fibronectin type 3; CCR, Coiled coil region; 5 nucleotid, 5 nucleotid domain; ATP-synt_ab_N, ATP-syntase domain; SP, signal peptide; TM, transmembrane motive; LCR, low complexity region; NA, no annotated. Programs used: Expasy (translation), SignalP 4.0 Server and SMART (Signal P information), SMART (protein domains).

\subsection{DISCUSSION}

In recent years, RNAseq and NGS related techniques have become more accessible and cheaper (Metzker, 2010), resulting in a large amount of genomic and transcriptomic information. However, most of this data has been generated from mammals and model organisms. Purification is a key factor to achieve good NGS sequencing from a 
microorganism, which is greatly facilitated when in vitro axenic cultures are available. Currently, for most parasites there are no in vitro cultures and there are many variables that difficult their establishment (Ahmed, 2014). Consequently, transcriptomic data from these organisms are scarce and frequently contaminated with host data, which hampers enormously their study at molecular levels (Ahmed, 2014). This is especially limiting with most histozoic parasites, which are intimately embedded in the host tissues. Myxozoans are parasites typically presenting two different stages in their hosts: the proliferative/vegetative stages, which feed and proliferate in the target tissues, and the spore stages, which are also produced in the host (Lom \& Dyková, 2006) but are known as quiescent stages (Liu et al., 2010). The spores serve as disseminative forms outside the current host and, at the same time, they may provide resistance through space and time. E. leei is a myxozoan histozoic parasite, whose proliferative stages not just dwell among enterocytes, but also develop pseudopods that attach to the neighbouring cells, making it more difficult to be separated from the host tissue (Sitjà-Bobadilla \& Palenzuela, 2012). When present in high numbers, separation of myxospores is relatively easy due to their homogenous shape and size and their protective valves. However, they are not a good source for transcriptomic studies, since transcriptomic information in resistant or quiescent stages is known to be quite limited (Beaudet et al., 2018). In addition the spores developed in the fish are not infective for other fish but, in any case, to an invertebrate host. Thus, their limited gene transcription profile is presumed to be quite different from that of stages that are infective and pathogenic for fish, which are more interesting in diagnostic or prophylactic strategies. Thus, an alternative may be the use of mixed cell preparations and a separation of RNAseq reads a posteriori using in silico pipelines (Foox et al., 2015).

The current approach consisted in building local BLAST databases with the limited pre-existing genetic data from related organisms, and developing a method to assign a probability value for each transcript based on the error rates of the classification criteria in a tutored system, using a smaller curated sequence dataset. Although the classification cutoff value chosen was conservative $(p>99 \%)$ and possibly disregarded many genuine parasite reads present in the classification grey zone, the lack of pre-existing genomic data on the parasite and the host was circumvented. A subtractive approach based on the sequencing and comparison of uninfected controls was disregarded, since control and infected host cells likely present different transcriptomic patterns and therefore the subtracted dataset would contain numerous host transcripts which may be overexpressed during the infection. For this reason, this pipeline constitutes a solution to unveil the transcriptome of histozoic parasites that are impossible to completely isolate from host cells, without the need of any reference sequence. Furthermore, this pipeline is adaptable, it works with probabilities, and so the stringency could be raised up to reduce the classification error, which also would affect the number of resulting transcripts 
The number of parasite transcripts obtained from this pipeline showed promising results, with over 14,000 E. leei transcripts, and less than $0.1 \%$ misclassification (classificationerrorrate).There are severalcriteria thatsupport thecorrectclassification of our transcripts: the low CG\% content, the quantity of transcripts obtained, and the amount of transcripts also found by blasting related species (Supplementary Table 3). Besides, it was found just a small percentage of our transcripts had BLAST hits in NCBI.

The distribution of the CG\% content in our assembled transcripts (Figure 3), presented two peaks, one located around 50\%, and other at 30-33\%. Probably, the largest peak, located slightly over $50 \%$, belonged to fish transcripts, as the gilthead sea bream genome has an average 54\% CG content (Pérez-Sánchez et al., 2019). Conversely, the peak around 30-33\% likely corresponds to parasite transcripts, since several Myxozoans are known to present relatively low CG\% content in their genomes: Myxobolus squamalis (GC\%: 27.3), Henneguya salminicola (CG\%: 29), Sphaeromyxa zaharoni (CG\%: 28), Kudoa iwatai (GC\%: 31.2), and Thelohanellus kitauei (CG\%: 34.5) (Data obtained from the NCBI database).

The number of transcripts obtained was also similar to other myxozoan genomes/ transcriptomes available in NCBI. Even changing the stringency of the classification, the numbers did not change substantially (Supplementary Table 4). It has been hypothesized that the transition to a parasitic lifestyle in myxozoans induced gene loss and a drastic reduction of the genome (Okamura et al., 2015; Sitjà-Bobadilla \& Palenzuela, 2012). In fact, this group is considered to have some of the smallest genomes known in metazoans (Chang et al., 2015). For example, free-living cnidarians such as Hydra vulgaris (Hydrozoa), Acropora millepora (Anthozoa), or Alatina alata (Cubozoa) have 31,988 (Evangelista et al., 2016), 56,260 (Moya et al., 2012), or 32,000 (Lewis-Ames et al., 2016) transcripts, respectively. However, cnidarian parasites have significantly fewer transcripts, like $H$. salminicola $(8,187)$, or T. kitauei $(15,020)$ (Feng et al., 2014). Interestingly, Polypodium hydriforme, which is a free-living organism with parasitic adaptations, has 24,516 transcripts (Shpirer et al., 2014), an intermediate number of transcripts between free-living and parasitic cnidarians.

Another fact supporting the robustness of our transcriptome was the similarity of E. leei transcripts with those from myxozoans like E. scophthalmi, K. iwatai and C. shasta, species that are phylogenetically closer to E. leei in the so called "marine clade", described in a phylogenetic tree based on SSU rDNA sequences (Fiala et al., 2015). Conversely, free-living cnidarians, such as $H$. vulgaris, which is a model organism with a well-defined transcriptome, share a lower percentage of transcripts with E. leei (Supplementary Table 3). 
Not surprisingly, robust annotation was only possible for $18.6 \%$ of E. leei transcripts. This is explained in part by the difficulties associated to the study of these organisms and their scarce presence in the available databases. In addition, the myxozoa are characterized by a very fast-clock evolution pace, leading to little similarity in protein-coding genes compared to their free-living cnidarian homologs and even to their myxozoan relatives (Yahalomi et al., 2017). Thus, the myxozoans not only express specific genes related to their adaptation to parasitism of which no homologs are found in well-represented model species, but they yield relatively poor scores in reciprocal searches between datasets from other myxozoans (Supplementary Table 3).

This newly acquired transcriptomic data was subsequently mined for candidate diagnostic and therapeutic targets against $E$. leei. Diagnostic candidate proteins were shortlisted using an in silico approach including prediction bioinformatics tools attending to several characteristics. The presence of a signal peptide was one of the primary shortlisting criteria. The signal peptide indicates that the newly synthetised protein is destined toward the secretory pathway, and as such it is likely inserted in cellular membranes or secreted to the extracellular region (Owji et al., 2018). Candidate proteins were also sought to hold functional domains. As this is a de novo assembled transcriptome, without previous genomic/transcriptomic references, the presence of known protein domains supports that the transcript is correctly assembled and not an assembly artefact. In addition, an important requirement for a diagnostic target is that it should present high expression levels in the infective stages within the fish. Thus, candidates that met all previous conditions and showed the highest expression levels were selected. Another important step was to check that these proteins did not show relevant homologies with the fish host, to avoid undesired cross-reactions. Indeed, the final list of candidates included only transcripts with unknown ontology during the GO annotation. Overall, despite being a conservative approach, this strategy showed to be very effective to mine the new transcriptomes without any reference, and to identify diagnostic and vaccine candidates without the need of an in vitro culture. A similar strategy has been recently followed to identify diagnostic and therapeutic targets with the myxozoan Tetracapsuloides bryosalmonae in trout, with promising results (Faber et al., 2019).

Once the candidate parasite proteins were chosen and their presence and sequence integrity was verified in parasite-infected cDNA libraries, efforts to generate monoclonal antibodies suitable for LFD quick diagnostic tests were made. Quality specific antibodies are an essential part in the design of immunochromatographic devices (Christopher et al., 2005) and the bottleneck in the development of new diagnostic tests. The first approach was based on conjugation of short peptides chosen from the selected targets, predicted to be externally expressed in the protein, with the carrier antigens OVA and KLH. This approach yielded one candidate polyclonal serum with reactivity against $E$. leei. However, when monoclonal antibodies were produced 
and screened, this reactivity turned out to be mainly targeted to the carrier KLH used during the immunization. Cross-reactivity of sera raised against E. leei proliferative stages and other myxozoan species has already been described (Estensoro et al., 2014). This effect is interpreted to be due to common terminal glycosylation patterns located in E. leei proliferative stages (Redondo \& Álvarez-Pellitero, 2009), and also reported in Sphaerospora molnari spores (Muñoz et al., 1999). The carrier antigenic peptide KLH (Swaminathan et al., 2014) is obtained from natural marine sources (the mollusc Megathura crenulata) and is predicted to be heavily glycosylated. Thus cross-reactivity with these glycosylation patterns would explain why a strong signal was just observed in polyclonal antisera against constructs with KLH, while the monoclonal antibodies derived from that mouse would not present sufficient specificity against the parasite. Also, the expression of a molecule similar to KLH by the parasite might be cause for unspecific staining in IHC. A similar effect was observed in the second immunization attempt, in which cross-reactivity was detected against the SUMO-tag. Nonetheless, promising results were obtained with unconjugated peptides, obtained through in vivo expression systems, from three different targets (TG-1, TG-5 and TG-6, Table 3). Studies are currently being conducted to characterize these antibodies to develop diagnostic tools to be applied as quick point of care tests in aquaculture. Even if the ongoing efforts with the targets and peptides designed in this study do not succeed in the development of suitable Mabs for this specific application, the availability of a good quality, filtered transcriptome of the parasite, allowing further characterization of numerous parasite proteins whose function is currently unknown, will allow further developments in this line.

Reverse vaccinology or the identification of vaccine candidates based on genome or transcriptome-wide bioinformatics analyses is increasingly gaining relevance for vaccine development (Guleria \& Jaiswal, 2020; He et al., 2012; Rinaudo et al., 2009). However, in this study, we did not consider this approach sufficient to warrant the identification of appropriatevaccine candidates. Even if the parasiteprotein is predicted to be externally expressed or highly immunogenic, the actual immunogenicity of it in a fish host cannot be easily anticipated until an in vivo challenge is performed in order to test its prophylactic value (Plant et al., 2009; von Gersdoff-f-Jørgensen et al., 2012). In this study, in order to pinpoint potential vaccine candidates among parasite proteins of known immunogenicity for the host, a more direct approach using Western blot analysis of parasite samples with serum from immune (parasiteresistant) fish, was used. The identified parasite protein bands were sequenced using mass spectrometry and the sequenced peptides were identified in the newly generated parasite transcriptomic database. Since these proteins are recognised by fish specific antibodies, they constitute ideal candidates for vaccine development.

Regarding the 12 immunogenic transcripts identified in the vaccine candidate search, only 5 were annotated in our E. leei transcriptome (Table 4). Among them, annexin and gamma-glutamil transferase have already been studied as putative parasite targets 
for vaccine development. Annexin is an interesting protein since it is related with structural stabilization of cell membranes (Hofmann et al., 2010), and despite being a ubiquitous protein family, there are different parasite taxa that possess unique annexin properties, which would allow the triggering of specific antibody responses (Hofmann et al., 2010). Also, abundance of annexins in parasites has been reported, like in the tegument of plathelminths, (de la Torre-Escudero et al., 2011; Leow et al., 2019; Song et al., 2016). However, no vaccine against a parasite's annexin has being successful so far (Leow et al., 2020). Gamma-glutamil transferase also appears as an interesting target since there are reports describing it as a virulence factor in some bacteria such as Helicobacter pylori (Zhang et al., 2015), Bacillus anthracis (Candela \& Fouet, 2005) or Acinetobacter baumannii (Elhossieny et al., 2020).

By contrast, the nature and function from the seven not annotated transcripts (7/12) also identified as antigenic transcripts remained unknown, and this result is consistent with the annotation of our de novo E. leei transcriptome, with more than $50 \%$ of E. leei transcripts that could not be annotated. However, the fact that they were immunogenic in fish resistant to the infection strengthens their interest. Related to this, several unknown genes from other pathogens have been successfully tested for their use as vaccine candidates after an extensive proteomic characterisation (Cardoso et al., 2008; Garbom et al., 2004). Furthermore, P14G8 and C-39373 from the myxozoan T. bryosalmonae are promising vaccine candidates but have unknown ontology (Faber et al., 2020). Two of our unknown transcripts contained a predicted signal $\mathrm{P}$ in their sequence, which makes them interesting for a deeper look (e.g. protein characterization, studies of differential expression, alternative splicing, etc.). Further efforts will be made to characterize these candidate targets with the aim of producing recombinant vaccines against enteromyxosis.

In summary, we have described an efficient pipeline to unravel the transcriptome of parasites which are impossible to separate from the host cells and for which there is a profound lack of basic research tools (e.g., in vitro cultures, specific antibodies, cell purification, etc.). Besides, we explored different approaches that can be used and combined in order to find out interesting molecules from the parasite that may serve as a foundation for the development of prophylactic and diagnostic tools. In further studies, two key questions must be addressed. Firstly, specific Mab production against the targets selected in our study, or against others yet overlooked in the E. leei transcriptome, must be tackled. Even though this task is severely impaired by the lack of pure and homogeneous parasite material necessary for efficient screening of the Mabs, the goal of developing affordable and reliable point-of-care diagnostic tools is much closer than before. In addition, a deeper study of the 12 antigenic peptides will be performed in order to select the most suitable candidate/s to design a recombinant vaccine against $E$. leei. 


\section{Bibliography}


Ahmed N. H. (2014) Cultivation of parasites. Trop Parasitol. 4:80-89.

Anderson R. M., May R. M. (1979) Population biology of infectious diseases: Part I. Nature. 280:361-367.

Athanassopoulou F., Prapas T., Rodger H. (1999) Diseases of Puntazzo puntazzo Cuvier in marine aquaculture systems in Greece. J Fish Dis. 22:215-218.

Beaudet D., Chen E., Mathieu S., Yildirir G., Ndikumana S., Dalpé Y., Séguin S., Farinelli L., Stajich J. E., Corradi N. (2018) Ultra-low input transcriptomics reveal the spore functional content and phylogenetic affiliations of poorly studied arbuscular mycorrhizal fungi. DNA Res. 25:217-227.

Candela T., Fouet A. (2005) Bacillus anthracis CapD, belonging to the gamma-glutamyltranspeptidase family, is required for the covalent anchoring of capsule to peptidoglycan. Mol Microbiol. 57:717-26.

Canning E. U., Okamura B. (2004) Biodiversity and evolution of the myxozoa. Adv Parasitol. 56:43-131.

Cardoso F. C., Macedo G. C., Gava E., Kitten G. T., Mati V. L., de Melo A. L., Caliari M. V., Almeida G. T., Venancio T. M., Verjovski-Almeida S., Oliveira, S. C. (2008) Schistosoma mansoni tegument protein Sm29 is able to induce a Th1-type of immune response and protection against parasite infection. PLoS Negl Trop Dis. 2:e308.

Chang E. S., Neuhof M., Rubinstein N. D., Diamant A., Philippe H., Huchon D., Cartwright P. (2015) Genomic insights into the evolutionary origin of Myxozoa within Cnidaria. PNAS USA. 112:14912-14917.

Christopher P., Robinson N., Shaw M. K. (2005) Antibody-label conjugates in lateral-flow assays, in: Wong R. C., Tse H. Y. (Eds.) Drugs of Abuse: Body Fluid Testing. Humana Press, New Jersey, USA. pp. 87-98.

Conesa A., Götz S., García-Gómez J., Terol J., Talon M., Robles M. (2005) BLAST2GO: A universal tool for annotation, visualization and analysis in functional genomics research. Bioinformatics. 21:3674-3676.

Cuadrado M., Marques A., Diamant A., Sitjà-Bobadilla A., Palenzuela O., Álvarez-Pellitero P., Padrós F., Crespo, S. (2008) Ultrastructure of Enteromyxum leei (Diamant, Lom, \& Dyková, 1994) (Myxozoa), an enteric parasite infecting gilthead sea bream (Sparus aurata) and sharpsnout sea bream (Diplodus puntazzo). J Eukaryot Microbiol. 55:178-184.

de la Torre-Escudero E., Manzano-Román R., Siles-Lucas M., Pérez-Sánchez R., Moyano J. C., Barrera I., Oleaga A. (2012) Molecular and functional characterization of a Schistosoma bovis annexin: Fibrinolytic and anticoagulant activity. Vet Parasitol.184:25-36.

Diamant A. (1995) Myxidium leei (Myxosporea) infections in sharpsnout sea bream Diplodus puntazzo (Cetti) and common sea bream Pagrus pagrus (L.) (Sparidae). Program and book of abstracts Institute of Zoology, Fish Biology and Fish Diseases, 4th lnt. Symp Fish Parasitology. Munich, Germany. pp. 8.

Diamant A., Lom J., Dyková I. (1994) Myxidium leei n. sp., a pathogenic myxosporean of cultured sea bream Sparus aurata. Dis Aquat Organ. 20:137-141.

Elhossieny N., Elhezawy N., Sayed R., Khattab M., Far M., Attia A. (2020) Gamma-glutamyl transferase is a novel virulence factor of Acinetobacter baumannii that induces alveolar wall destruction and renal damage in systemic pathology. J Infect dis. 222:871-879

Estensoro I., Redondo M. J., Álvarez-Pellitero P., Sitjà-Bobadilla A. (2010) Novel horizontal transmission route for Enteromyxum leei (Myxozoa) by anal intubation of gilthead sea bream Sparus aurata. Dis Aquat Organ. 92:51-58.

Estensoro I., Álvarez-Pellitero P., Sitjà-Bobadilla A. (2013) Antigenic characterization of Enteromyxum leei (Myxozoa: Myxosporea). Dis Aquat Organ. 106:149-162.

Estensoro I., Redondo M. J., Álvarez-Pellitero P., Sitjà-Bobadilla A. (2014) Immunohistochemical characterization of polyclonal antibodies against Enteromyxum leei and Enteromyxum scophthalmi (Myxozoa: Myxosporea), intestinal parasites of fish. J Fish Dis. 37:785-796.

Evangelista D., Tripathi K. P., Guarracino M. R. (2016) An Atlas of annotations of Hydra vulgaris transcriptome. BMC bioinformatics. 17:360.

FAO. FAO yearbook. Fishery and Aquaculture Statistics 2016. Rome (2018). 
Faber M. N., Holland J. W., Secombes C. J. (2019) Vaccination strategies and IgM responses against PKD in rainbow trout. Fish Shellfish Immunol. 91:423.

Feng J. M., Xiong J., Zhang J. Y., Yang Y. L, Yao B., Zhou Z. G., Miao W. (2014) New phylogenomic and comparative analyses provide corroborating evidence that Myxozoa is Cnidaria. Mol Phylogenet Evol. 81:10-18.

Faber M. N., Yoon S., Shaw S., Paiva-Alves E., Wang B., Qi Z., Okamura B., Hartikainen H., Secombes C. J., Holland J. W. (2020) Comparative transcriptomics and host-specific parasite gene expression profiles inform on drivers of proliferative kidney disease. bioRxiv

Fiala I., Bartošová-Sojková P., Okamura B., Hartikainen H. (2015) Adaptive radiation and evolution within the Myxozoa, in: Okamura B., Gruhl A., Bartholomew J. L. (Eds.) Myxozoan Evolution, Ecology and Development. Springer International Publishing, Switzerland. pp. 69-81.

Foox J., Ringuette M., Desser S. S., Siddall M. E. (2015) In silico hybridization enables transcriptomic illumination of the nature and evolution of Myxozoa. BMC Genomics. 16:840.

Fox M. D., Palenzuela O., Bartholomew J. L. (2011) Strategies for the diagnosis of Ceratomyxa shasta using the polymerase chain reaction: Comparison of lethal and nonlethal sampling with microscopic examination. $J$ Aquat Anim Health. 12:100-106.

Garbom S., Forsberg A., Wolf-Watz H., Kihlberg B. M. (2004) Identification of novel virulence-associated genes via genome analysis of hypothetical genes. Infect Immun. 72:1333-1340.

Golomazou E., Athanassopoulou F., Karagouni E., Tsagozis P., Tsantilas H., Vagianou S. (2006) Experimental transmission of Enteromyxum leei Diamant, Lom and Dyková, 1994 in sharpsnout sea bream, Diplodus puntazzo C. and the effect on some innate immune parameters. Aquaculture. 260:44-53.

Guleria V., Jaiswal V. (2020) Comparative transcriptome analysis of different stages of Plasmodium falciparum to explore vaccine and drug candidates. Genomics. 112:796-804.

He Y. (2012) Omics-based systems vaccinology for vaccine target identification. Drug Dev Res. 73:559-568.

Horton P., Park K. J., Obayashi T., Fujita N., Harada H., Adams-Collier C. J., Nakai K. (2007) WoLF PSORT: Protein localization predictor. Nucleic Acids Res. 35:585-587.

Kent M., Andree K., Bartholomew J., El-Matbouli M., Desser S. S., Devlin H. R., Feist, S., Hedrick P. R., Hoffmann W. R., Khattra J., Hallett S., Lester R., Longshaw M., Palenzuela O., Siddall E. M., Xiao C. (2001) Recent advances in our knowledge of the Myxozoa. J Eurkaryot Microbiol. 48:395-413.

le Breton A., Marques A. (1995) Occurrence of an histozoic Myxidium infection in two marine cultured species: Puntazzo puntazzo C. and Pagrus major. Bull Eur Association Fish Pathol. 15:210-212.

Leow C. Y., Willis C., Chuah C., Leow C. H., Jones M. (2020) Immunogenicity, antibody responses and vaccine efficacy of recombinant annexin B30 against Schistosoma mansoni. Parasite Immunol. 42:e12693.

Leow C. Y., Willis C., Leow C. H., Hofmann A., Jones M. (2019) Molecular characterization of Schistosoma mansoni tegument annexins and comparative analysis of antibody responses following parasite infection. Mol Biochem Parasitol. 234:111231.

Letunic I., Bork P. (2018) 20 years of the SMART protein domain annotation resource. Nucleic Acids Res. 46:D493D496.

Lewis-Ames C., Ryan J. F., Bely A. E., Cartwright P., Collins A. G. (2016) A new transcriptome and transcriptome profiling of adult and larval tissue in the box jellyfish Alatina alata: An emerging model for studying venom, vision and sex. BMC Genomics. 17:650.

Liu Y., Whipps C. M., Gu Z. M., Zeng L. B. (2010) Myxobolus turpisrotundus (Myxosporea: Bivalvulida) spores with caudal appendages: Investigating the validity of the genus Henneguya with morphological and molecular evidence. Parasitol Res. 107:699-706.

Lom J., Dyková I. (2006) Myxozoan genera: Definition and notes on taxonomy, life-cycle terminology and pathogenic species. Folia Parasitol. 53:1-36. 
Metzker M. L. (2010) Sequencing technologies - the next generation. Nat Rev Genet.11:31-46.

Mitchell A. L., Attwood T. K., Babbitt P. C., Blum M., Bork P., Bridge A., Brown S. D., Chang H. Y., El-Gebali S., Fraser M. I., Gough J., Haft D. R., Huang H., Letunic I., Lopez R., Luciani A., Madeira F., Marchler-Bauer A., Mi H., Natale D. A., Necci M., Nuka G., Orengo C., Pandurangan A. P., Paysan-Lafosse T., Pesseat S., Potter S. C., Qureshi M. A., Rawlings N. D., Redaschi N., Richardson L. J., et al. (2019) InterPro in 2019: improving coverage, classification and access to protein sequence annotations. Nucleic Acids Res. 47:351-360.

Moya A., Huisman L., Ball E. E., Hayward D. C., Grasso L. C., Chua C. M., Woo H. N., Gattuso J. P., Forêt S., Miller D. J. (2012) Whole transcriptome analysis of the coral Acropora millepora reveals complex responses to $\mathrm{CO}_{2}$-driven acidification during the initiation of calcification. Mol Ecol. 21:2440-2454.

Muñoz P., Palenzuela O., Álvarez-Pellitero P., Sitjà-Bobadilla A. (1999) Comparative studies on carbohydrates of several myxosporean parasites of fish using lectin histochemical methods. Folia Parasitol. 46:241-247.

Nielsen H., Tsirigos K. D., Brunak S., von Heijne G. (2019) A brief history of protein sorting prediction. Protein J. 38:200-216.

Okamura B., Gruhl A., Bartholomew J. L. (2015) An introduction to myxozoan evolution, ecology and development, in: Okamura B., Gruhl A., Bartholomew J. L. (Eds.) Myxozoan Evolution, Ecology and Development. Springer International, Switzerland. pp. 1-20.

Owji H., Nezafat N., Negahdaripour M., Hajiebrahimi A., Ghasemi Y. (2018) A comprehensive review of signal peptides: Structure, roles, and applications. Eur J Cell Biol. 97:422-441.

Palenzuela O., Sitjà-Bobadilla A., Álvarez-Pellitero P. (1996) Isolation and partial characterization of serum immunoglobulins from sea bass (Dicentrarchus labrax L.) and gilthead sea bream (Sparus aurata L.). Fish Shellfish Immunol. 6:81-94.

Palenzuela O. (2006) Myxozoan infections in Mediterranean mariculture. Parassitologia. 48:27-29.

Pérez-Sánchez J., Estensoro I., Redondo M. J., Calduch-Giner J. A., Kaushik S., Sitjà-Bobadilla A. (2013) Mucins as diagnostic and prognostic biomarkers in a fish-parasite model: Transcriptional and functional analysis. PLoS One. 8:e65457.

Pérez-Sánchez J., Naya-Català F., Soriano B., Piazzon M. C., Hafez A., Gabaldón T., Llorens C., Sitjà-Bobadilla A., Calduch-Giner J. A. (2019) Genome sequencing and transcriptome analysis reveal recent species-specific gene duplications in the plastic gilthead sea bream (Sparus aurata). Front Mar Sci. 6:760.

Piazzon M. C., Estensoro I., Calduch-Giner J. A., del Pozo R., Picard-Sánchez A., Pérez-Sánchez J., Sitjà-Bobadilla A. (2018) Hints on T cell responses in a fish-parasite model: Enteromyxum leei induces differential expression of T cell signature molecules depending on the organ and the infection status. Parasite Vector.11.

Picard-Sánchez A., Estensoro I., del Pozo R., Piazzon M. C., Palenzuela O., Sitjà-Bobadilla, A. (2019) Acquired protective immune response in a fish-myxozoan model encompasses specific antibodies and inflammation resolution. Fish Shellfish Immunol. 90: 349-362.

Plant K. P., LaPatra S. E., Cain K. D. (2009) Vaccination of rainbow trout, Oncorhynchus mykiss (Walbaum), with recombinant and DNA vaccines produced to Flavobacterium psychrophilum heat shock proteins 60 and 70 . J Fish Dis. 32:521-34.

Redondo M. J., Álvarez-Pellitero P. (2009) Lectin histochemical detection of terminal carbohydrate residues in the enteric myxozoan Enteromyxum leei parasitizing gilthead seabream Sparus aurata (Pisces: Teleostei): A study using light and transmission electron microscopy. Folia Parasitol. 56:259-267.

Redondo M. J., Palenzeula O., Álvarez-Pellitero P. (2003) In vitro studies on viability and proliferation of Enteromyxum scophthalmi (Myxozoa), an enteric parasite of cultured turbot Scophthalmus maximus. Dis Aquat Organ. 55:133-144.

Rigos G., Katharios P. (2010) Pathological obstacles of newly-introduced fish species in Mediterranean mariculture: A review. Rev Fish Biol Fisher. 20:47-70.

Rinaudo C. D., Telford J. L., Rappuoli R., Seib K. L. (2009) Vaccinology in the genome era. J Clin Invest. 119:2515-2525. 
Sastre P., Dijkman R., Camuñas A., Ruiz T., Jebbink M. F., van der Hoek L., Vela C., Rueda P. (2011) Differentiation between human coronaviruses nl63 and 229e using a novel double-antibody sandwich enzyme-linked immunosorbent assay based on specific monoclonal antibodies. Clin Vaccine Immunol. 18:113-118.

Shinn A. P., Pratoomyot J., Bron J. E., Paladini G., Brooker E. E., Brooker A. J. (2015) Economic costs of protistan and metazoan parasites to global mariculture. Parasitology. 142:196-270.

Shpirer E., Chang E. S., Diamant A., Rubinstein N., Cartwright P., Huchon D. (2014) Diversity and evolution of myxozoan minicollagens and nematogalectins. BMC Evol Biol. 14:205.

Sitjà-Bobadilla A., Palenzuela O. (2012) Enteromyxum species, in: Woo P. T. K., Buchmann K. (Eds.) Fish Parasites: Pathology and Protection. CAB International, Oxfordshire, UK. pp. 163-176.

Swaminathan A., Lucas R. M., Dear K., McMichael A. J. (2014) KLH as neoantigen in human immunotoxicological studies. Br J Clin Pharmacol. 78:1135-1142.

von Gersdorff Jørgensen L., Sigh J., Kania P. W., Holten-Andersen L., Buchmann K., Clark T., Rasmussen J. S., EinerJensen K., Lorenzen N. (2012) Approaches towards DNA vaccination against a skin ciliate parasite in fish. PLoS One. 7:e48129.

Yahalomi D., Haddas-Sasson M., Rubinstein N. D., Feldstein T., Diamant A., Huchon D. (2017) The multipartite mitochondrial genome of Enteromyxum leei (myxozoa): Eight fast-evolving megacircles. Mol Biol Evol. 34:15511556.

Yokoyama H. (2003) A Review: Gaps in our knowledge on myxozoan parasites of fishes. Fish Pathol. 38:125-136.

Zhang X., Zhang J., Yang F., Wu W., Sun H., Xie Q., Si W., Zou Q., Yang Z. (2015) Immunization with heat shock protein A and $\gamma$-glutamyl transpeptidase induces reduction on the Helicobacter pylori colonization in mice. PloS One. 10:e0130391. 
CHAPTER 4 


\section{SUPPLEMENTARY MATERIAL}

Supplementary Table 1. Databases used in this study to separate fish from parasite transcripts. The fish database was composed by 12 fish species. The Myxozoan/Cnidarian database was composed by 10 (free-living and parasitic) species.

\begin{tabular}{|c|c|c|c|}
\hline Fish database & $\begin{array}{l}\text { Transcritome (T) or/ } \\
\text { and Genome (G) }\end{array}$ & $\begin{array}{l}\text { Myxozoan/Cnidarian } \\
\text { database }\end{array}$ & $\begin{array}{l}\text { Transcritome (T) or/ } \\
\text { and Genome (G) }\end{array}$ \\
\hline Astyanax mexicanus & G & Myxobolis cerebralis & $\mathrm{T}$ \\
\hline Danio rerio & G & Thelohanellus kitauei & $T \& G$ \\
\hline Gadus morhua & G & Ceratomyxa shasta & G \\
\hline Gasterosteus aculeatus & G & $\begin{array}{l}\text { Polypodium } \\
\text { hydriforme }\end{array}$ & $\mathrm{T}$ \\
\hline Latimeria chalumnae & G & Hydra vulgaris & $\mathrm{G}$ \\
\hline Lepisosteus oculatus & G & Nematostella vectensis & G \\
\hline Oreochromis niloticus & G & Acropora digitifera & G \\
\hline Oryzias latipes & G & Alastina moseri & G \\
\hline Petromyzon marinus & G & Aurelia spp. & G \\
\hline Takifugu rubripes & G & Hydra magnipillata & G \\
\hline Tetraodon nigroviridis & G & & \\
\hline $\begin{array}{l}\text { Xiphophorus } \\
\text { maculatus }\end{array}$ & G & & \\
\hline
\end{tabular}

Supplementary Table 2. Full ORF primers of selected targets using an in silico approach.

\begin{tabular}{|c|c|c|c|}
\hline Target & $\begin{array}{l}\text { Full ORF } \\
\text { length (nt) }\end{array}$ & Primers & $5-3$ ' Sequence \\
\hline \multirow[t]{2}{*}{ TG-1 } & \multirow{2}{*}{663} & FW & ATG ATA ATA TTA AAA ATT GCC TTC ATT \\
\hline & & RV & TTA AAC CCA GGA ACA GTG T \\
\hline \multirow[t]{2}{*}{ TG-2 } & \multirow{2}{*}{663} & FW & ATG GTG ACG CTT CCA ATA \\
\hline & & $\mathrm{RV}$ & T CAA ACC CAT GAA CAG TTT TTT CTA AG \\
\hline \multirow[t]{2}{*}{ TG-3 } & \multirow{2}{*}{639} & FW & ATG GGG TTT TCC AAT TTG \\
\hline & & $\mathrm{RV}$ & T TAA TCA AGT TTT TGT TCT TCA TCG TTG \\
\hline \multirow[t]{2}{*}{ TG-4 } & \multirow{2}{*}{960} & FW & ATG ATA TTA ATT TGG CTG TTT ATT TTG \\
\hline & & $\mathrm{RV}$ & T TAG AAA GGA CTA ATC TTC CTG C \\
\hline \multirow[t]{2}{*}{ TG-5 } & \multirow{2}{*}{1155} & FW & ATG ATT ATA ATT GTA GCT TTT TAT TTT TTG \\
\hline & & $\mathrm{RV}$ & T TAT TCA GAA TTG GAA TAA GCT GAC \\
\hline \multirow[t]{2}{*}{ TG-6 } & \multirow{2}{*}{879} & FW & ATG AAT TGG AAG AAA GAG CTT \\
\hline & & $\mathrm{RV}$ & T TAT TCT TCT AAA TCG TAA GTG GGA GAG \\
\hline \multirow[t]{2}{*}{ TG-7 } & \multirow{2}{*}{1524} & FW & ATG ACT CGA TGT TTG T \\
\hline & & $\mathrm{RV}$ & TCA ACA ATA TAA AAA AAA CGC TTT AAA TT \\
\hline
\end{tabular}


Supplementary Table 3. Percentage of Enteromyxum leei transcripts found by Blastx (e-val $\left.=10^{-5}\right)$ in other myxozoan databases. Annotated E. leei transcripts are those that were found by BLAST in NCBI (35.4\% of E. leei transcripts). Unknown E. leei transcripts are those for which NCBI BLAST did not yield a positive result (64.6\% of E. leei transcripts).

\begin{tabular}{l|c|c} 
& Annotated E. leei transcripts & Unknown E. leei transcripts \\
\hline $\begin{array}{l}\text { Tetracapsuloides bryosalmonae } \\
\text { (fish) }\end{array}$ & $60.00 \%$ & $0.00 \%$ \\
\hline $\begin{array}{l}\text { Tetracapsuloides bryosalmonae } \\
\text { (invertebrate) }\end{array}$ & $78.00 \%$ & $0.00 \%$ \\
\hline Thelohanellus kitauei & $63.00 \%$ & $1.00 \%$ \\
\hline Kudoa iwatai & $89.00 \%$ & $0.00 \%$ \\
\hline Enteromyxum scophthalmi & $99.99 \%$ & $99.96 \%$ \\
\hline Ceratonova shasta & $92.00 \%$ & $0.00 \%$ \\
\hline Myxobolus pendula & $74.00 \%$ & $1.00 \%$
\end{tabular}

Supplementary Table 4. Number of transcripts obtained from the pipeline stablishing different stringency. $p(\mathrm{C} / \mathrm{M})=$ Probability to be Cnidarian/Myxozoan; $p(\mathrm{~F})=$ Probability to be Fish. Superscript explanation: $\left({ }^{\mathrm{a}}\right)=$ Higher probability to be Cnidarian/Myxozoan than Fish; $\left(^{(}\right)=$Probability between $50 \%$ to $99 \%$ to be Cnidarian/ Myxozoan; $\left(^{(}\right)=$Higher probability than $99 \%$ to be Cnidarian/Myxozoa; $\left({ }^{d}\right)=$ Higher probability than $99.9 \%$ to be Cnidarian/Myxozoa. In bold cut-off chosen for the study.

\begin{tabular}{|c|c|c|c|c|}
\hline Cutt-off point & $p(\mathrm{C} / \mathrm{M})<\boldsymbol{p}(\mathbf{F})^{\mathrm{a}}$ & $\begin{array}{l}0.5<p(\mathrm{C} / \mathrm{M})< \\
0.99^{\mathrm{b}}\end{array}$ & $p(\mathrm{C} / \mathrm{M})>0.99^{\mathrm{c}}$ & $p(\mathrm{C} / \mathrm{M})>0.999^{\mathrm{d}}$ \\
\hline E. leei transcripts & 20,266 & 74,821 & 12,784 & 8,571 \\
\hline
\end{tabular}




$$
216
$$

216 


\section{Chapter 5}

\section{Enterospora nucleophila (Microsporidia) in gilthead sea bream (Sparus aurata): Pathological effects and cellular immune response in natural infections}

Amparo Picard-Sánchez; M. Carla Piazzon; Nahla Ahmed, Raquel Del Pozo; Ariadna Sitjà Bobadilla; Oswaldo Palenzuela

INSTITUTO DE ACUICULTURA TORRE DE LA SAL CONSEJO SUPERIOR DE INVESTIGACIONES CIENTÍFICAS (IATS-CSIC), Torre de la Sal s/n 12595 Castellón Spain

(Vet Pathol. 57(4):565-576, 2020) 
Control of enteric parasitic diseases of farmed gilthead sea bream 


\subsection{ABSTRACT}

Enterospora nucleophila is a microsporidian responsible for an emaciative disease in gilthead sea bream (Sparus aurata). Its intranuclear development and the lack of in vitro and in vivo models hinder its research. This study investigated the associated lesions, its detection by qPCR, and the cellular immune response of naturally infected fish. The intensity of infection in the intestine was correlated with stunted growth and reduced body condition. At the beginning of the outbreaks, infection prevalence was highest in intestine and stomach and in subsequent months the prevalence decreased in the intestine and increased in hematopoietic organs and stomach. In heavy infections, intestinal histologic lesions were enterocyte hypercellularity and proliferation of rodlet cells. Infected enterocytes had $E$. nucleophila spores in the cytoplasm, and a pyknotic nucleusor karyorhexis or karyolysis. Lymphocytes were present at the base of the mucosa and eosinophilic granule cells were located between the enterocytes. In intestinal submucosa, macrophage aggregates containing spores were surrounded by lymphocytes and granulocytes, with submucosal infiltration of granulocytes. Macrophage aggregates appeared to develop into granulomata with necrotic areas containing parasite remnants. Immunohistochemistry revealed mast cells as the main type of granulocyte involved. Abundant $\operatorname{IgM}^{+}$and $\mathrm{IgT}^{+}$cells were identified by in situ hybridization in the submucosa when intracytoplasmic stages were present. This study describes the lesions of E. nucleophila in gilthead sea bream, an important aquaculture species.

\section{Key words}

Enterocytozoonidae, histopathology, immunoglobulins, granulocytes, growth retardation, qPCR, fish. 


\subsection{INTRODUCTION}

Microsporidia are highly specialized obligate intracellular (intracytoplasmic and/ or intranuclear) eukaryotes that are closely related to the Fungi (Han \& Weiss, 2017). They have a relatively simple development, consisting of two general stages: merogony and sporogony. Meronts multiply inside the infected host cell, eventually forming sporonts and then spores, which are ultimately released from the host and transmit the infection. There are almost 200 genera and over 1,400 described microsporidian species, though the actual diversity is estimated to be much higher. The host range extends from protists and invertebrates (especially insects and other arthropods) to vertebrates, particularly fish and mammals including humans (Cali \& Takvorian, 1999). Diverse pathological effects of microsporidia have been described in healthy and immunocompromised humans (Didier \& Weiss, 2011; Hassan et al., 2018), in companion animals, and especially in livestock such as bees, silkworms, crabs, lobsters and fish (Brown, 2017; Genersch, 2010; Gupta et al., 2016; Lom \& Dyková, 2005; Morado, 2011; Shields, 2011; Vergneau-Grosset \& Larrat, 2016). Over half of the known genera infect aquatic organisms and some are considered emerging pathogens in the food chain (Stentiford et al., 2016). About 120 species of microsporidia have been described from fish, and several are involved in diseases of wild, ornamental, experimental models, and farmed stocks. Their impact on fish health is well acknowledged, either producing direct mortalities, diminishing catch value, reducing growth rates, increasing the chances of predation by other animals, or impairing the reproductive or the cardiorespiratory capacities (Kent et al., 2014; Lom, 2002; Stentiford et al., 2016).

Enterospora nucleophila is an emerging pathogen in gilthead sea bream (Sparus aurata) culture in the Mediterranean area. It is an intranuclear microsporidian species belonging to the family Enterocytozoonidae, which includes human and aquatic hosts. Since its first description in Spanish aquaculture facilities (Palenzuela et al., 2014), it has also been detected in Italian and Greek gilthead sea bream farms, and in different facilities including on-growing net cages and landbased nurseries (Ahmed et al., 2019; Caffara et al., 2014). Information related to other fish intranuclear microsporidians is scarce. Mortalities have been reported due to Nucleospora salmonis in Chinook and Atlantic salmon (Bravo, 1996; Elston et al., 1987), to Desmozoon lepeophtherii (syn. Paranucleospora theridion) in Atlantic salmon (Nylund et al., 2010; Weli et al., 2017), to Nucleospora cyclopteri in the cleaner fish lumpsucker (Cyclopterus lumpus) (Freeman et al., 2013), and to an unidentified intranuclear microsporidium in grouper (Epinephelus spp.) (Xu et al., 2017). 
Studies on E. nucleophila are hindered by its very small size (spores are $1 \mathrm{x} 1.5 \mu \mathrm{m}$ ), its intranuclear development, and the lack of in vitro and in vivo propagation models. Limited information about the pathology has been presented elsewhere (Ahmed et al., 2019; Palenzuela et al., 2014). In this work, we investigated the pathological effects of this infection, its location within the host, and the cellular immune response invoked in naturally infected gilthead sea bream from different disease outbreaks in Mediterranean farms.

\subsection{MATERIALS AND METHODS}

\subsubsection{Fish and samplings}

All experimental protocols involving fish were approved by the Ethics and Animal Welfare Committee of IATS, CSIC and Generalitat Valenciana (approval number 151-2014). They were carried out in a registered installation facility (code ES120330001055) in accordance with the principles published in the European Animal Directive (2010/63/EU) and Spanish laws (Royal Decree RD53/2013) for the protection of animals used in scientific experiments. All efforts were made to minimize the suffering of the animals.

Three lots of gilthead sea bream ( $\mathrm{n}=300$ for lot 1 and $n=200$ each for lots 2 and 3 ) on-growing in commercial sea cages in the Western Mediterranean and displaying emaciation, were transported alive to the Institute of Aquaculture Torre de la Sal (IATS-CSIC) facilities. Upon arrival, 200, 92 and 20 fish (from lots 1, 2 and 3, respectively) were sacrificed by overexposure to the anaesthetic (MS-222, 0.1g/L; Sigma). After biometry and necropsy, intestinal samples were taken for molecular diagnosis by quantitative polymerase chain reaction (qPCR), as well as formalin fixation for histopathology. The remaining 100, 108 and 180 fish of lots 1, 2 and 3 , respectively, were kept in the open-flow facilities of IATS-CSIC and mortality was recorded for 152, 79 and 296 days (lots 1, 2 and 3, respectively). Lot 3 was also used to study the progression of the infection in different time points for 296 days post-initial detection (dpid). Fish were sampled at $44(\mathrm{n}=10), 57(\mathrm{n}=10), 92(\mathrm{n}=$ 10), $130(\mathrm{n}=10)$ and $296(\mathrm{n}=21) \mathrm{dpid}$, and their condition factor (calculated as 100 $\times$ body weight) / length ${ }^{3}$ ) and specific growth rate (calculated as $100 \times($ (ln final body weight) - (ln initial body weight)) / days) were calculated. From the same fish, intestines were collected for molecular diagnosis by qPCR. At 92, 130 and 296 dpid, additional samples of stomach, gallbladder, head kidney and spleen were collected for molecular diagnosis. During this time, fish were fed commercial pellets (Biomar) and disease signs and mortalities were recorded. 
Simultaneously, another lot of 100 clinically healthy gilthead sea bream (no disease signs of any bacterial or parasitic disease) from the same fish farm, and qPCR-negative for E. nucleophila, were reared under the same conditions as the infected ones.

\subsubsection{Diagnosis of E. nucleophila infection}

qPCR

Oligonucleotide probes targeting the SSU rDNA gene of E. nucleophila were designed from an alignment of available Microsporidia SSU rDNA genotypes, including 209 Enterocytozoonidae (Ahmed et al., 2019). Unique E. nucleophila segments, or segments with sufficient variation with respect to the closest taxa, were visually identified in the alignment. Choice of the best probes targeting these segments, according to specificity and thermodynamic properties, was aided by the software package OLIGO 7 (Rychlik, 2007). Two oligonucleotides were chosen as primers for a SYBR qPCR test: forward ENU-101F23: 5’ TGC GCT AAT TTG CTT TAT ACG AG 3' and reverse ENU-151R22 5' ATT GCA CCT TAT TCT ACA CTC T 3'. PCR reactions were assembled in $20 \mu$ l volume with $2 \mu \mathrm{l}$ template DNA and $300 \mathrm{nM}$ each primer in a SYBR commercial mastermix (PyroTaq Evagreen, CMB, Spain). The reactions were programmed in a thermal cycler with a $15 \mathrm{~min}$ Taq activation step $\left(95^{\circ} \mathrm{C}\right)$ followed by 40 cycles of denaturation $\left(95^{\circ} \mathrm{C}, 15 \mathrm{~s}\right)$; annealing $\left(50^{\circ} \mathrm{C}, 30 \mathrm{~s}\right)$ and extension $\left(72^{\circ} \mathrm{C}, 30 \mathrm{~s}\right)$. Standards consisted of on 10-fold dilutions with known amounts of a plasmid containing the target gene (covering 7 orders of magnitude) were run with each plate. Only data from reactions with standard curves within an efficiency range $(E=0.95-1.05)$, and $R^{2}>0.99$ were accepted. Samples with $\mathrm{Ct}<38$ were considered positive.

\section{DNA}

Was extracted from clinical samples using a robotic system (EpMotion 5070, Eppendorf, Hamburg, Germany) with dedicated DNA extraction kits (Nucleospin, MachereyNagel, Germany). The test samples consisted of small pieces of tissue (50-100 mg) or an aliquot $(200 \mu \mathrm{l})$ of an intestine homogenate. For the homogenates, the tissue $(<2 \mathrm{~g})$ was placed in $5 \mathrm{ml}$ tubes containing ice-cold saline and $3 \mathrm{~g}$ of mixed homogenization beads ( $2 \mathrm{~mm}, 3.2 \mathrm{~mm}$ and $3.5 \mathrm{~mm}$ UFO shape), which were then processed in a laboratory blender (Bullet Blender, Next Advance, USA) with 3x 5-min cycles at $4^{\circ} \mathrm{C}$. Blood samples were drawn with 0.5 M EDTA-coated syringes. Small aliquots $(10 \mu \mathrm{l})$ were transferred to microtubes and directly diluted in lysis buffer and processed with a dedicated kit (Nucleospin Blood). Quantification and quality control of extracted DNA samples was monitored with a spectrophotomer (Nanodrop, Thermo Scientific, Spain). 
Calcofluor-white stain: Paraffin sections ( $4 \mu \mathrm{m}$ thickness) were cut and mounted onto electrostatically charged glass slides (Superfrost-Plus; Thermo Fisher Scientific, Spain). Air-dried blood smears were also prepared. They were stained with $0.1 \%$ calcofluor white M2R stain in ${ }_{\text {dd }} \mathrm{H} 2 \mathrm{O}$ with a drop of $10 \%$ potassium hydroxide, for $1 \mathrm{~min}$. The slides were rinsed immediately with $30 \%$ ethanol. A light counterstaining was achieved with $0.1 \%$ Evans blue solution containing a few drops of glacial acetic acid for $1 \mathrm{~min}$. Slides were dehydrated mounted in DPX and examined using an Olympus BX51 fluorescence microscope under UV excitation light.

We use the term "clinically diseased" fish for those in the enzootically affected farms that showed the typical disease signs previously described for E. nucleophila infection: anorexia, cachexia, swollen abdominal cavity, and transparent intestinal walls (Palenzuela et al., 2014). Those fish were generally positive by qPCR and histology. On the contrary, "non-clinically diseased" fish were those that did not show clinical signs but were positive by qPCR, and in most cases negative by histology.

\subsubsection{Histology, immunohistochemistry and in situ hybridization}

Formalin-fixed tissues were dehydrated in a graded ethanol series, embedded in paraffin or methacrylate resin (Technovit 7100, Kultzer, Wehrheim, Germany), sectioned at $1-\mu \mathrm{m}$ for resin or $4-\mu \mathrm{m}$ for paraffin) and stained with Giemsa. Immunohistochemistry was used to discriminate between mast cells and acidophilic granulocytes, among the eosinophilic granule cells. For such purpose, paraffin sections ( $4 \mu \mathrm{m}$-thick) were mounted on super-frost plus slides and a rabbit-anti-histamine antibody (SigmaAldrich) was used to detect mast cells (Estensoro et al., 2014).

RNA-in situ hybridization (RNA-ISH) was used to detect transcripts of IgM and IgT. It was performed using the ViewRNA ISH Tissue 2-plex Assay kit (Affymetrix), which uses a proprietary DNA signal amplification technology allowing simultaneous detection of two target mRNAs in tissue sections with single copy sensitivity. The probe sets were designed using the sequences of gilthead sea bream IgM (accession numbers: JQ811851 and KX599199) and IgT (KX599200 and KX599201) heavy chains, in regions 20-903 and 2-901, respectively. Variable domains and regions not expressed both in the soluble and the membrane-bound forms were excluded, to allow detection of all transcripts regardless of the form. The ISH procedure was performed with $4 \mu \mathrm{m}$-thick tissue sections following the manufacturer's instructions, using a 10 min heat pretreatment at $90-95^{\circ} \mathrm{C}$ and a $30 \mathrm{~min}$ protease step at $40^{\circ} \mathrm{C}$. After probe hybridization and development with Fast Blue and Fast Red substrates, the slides were counterstained with Gill's hematoxylin $25 \%$ for 3 min, washed and mounted in aqueous mounting medium. 


\subsubsection{Statistics}

Statistical analyses were performed with GraphPad Prism 8 (GraphPad Software, Inc., San Diego, CA). We searched for covariations between infection status and fish biometrical variables using nonparametric Spearman correlation analyses. Differences between groups were studied with appropriate tests according to the variable studied, as detailed in the Results section. Average Ct values from qPCR reactions are given as the estimated mean $\pm \mathrm{CI}_{95 \%}$.

\subsection{RESULTS}

\subsubsection{Disease signs}

\section{Growth arrest and emaciation}

The specific growth rate of a naturally infected stock (100\% prevalence at the arrival to the laboratory) was determined to be 0.38 during 296 days, about $20 \%$ of that of a healthy stock of gilthead sea bream of equivalent size held under the same diet and conditions for the same period (i.e. 1.9). Using grouped data from all the fish identified as infected in this study, a statistically significant positive correlation between the condition factor and the infection intensity (as determined by the qPCR Ct values from intestinal samples) was found (Figure 1), indicating an inverse relationship between infection intensity and condition factor. In a subsample of naturally infected fish from lot 3 maintained in the laboratory up to $296 \mathrm{dpid}$ and sampled periodically, a clear decrease in the prevalence and intensity of infection and an improved condition factor with time was observed (Figure 2).

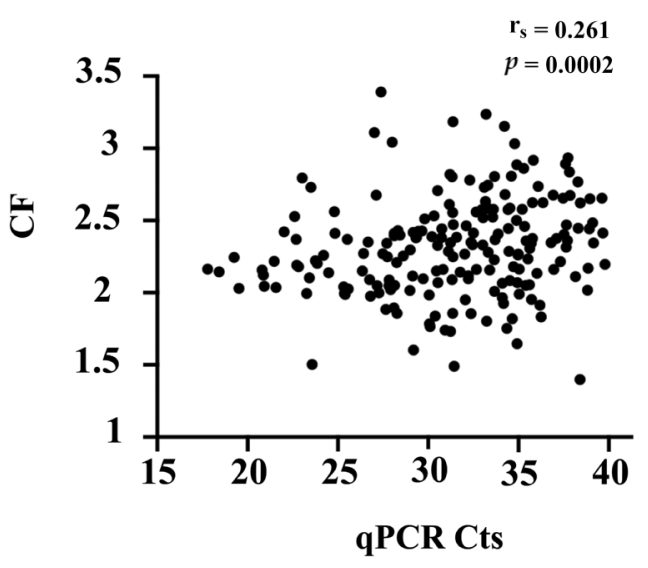

Figure 1. Correlation between intensity of infection by Enterospora nucleophila (qPCR Ct values) and fish body condition factor (CF). Higher intensity of infection (lower Ct) correlates with worse CF in fish obtained from different outbreaks (Lot 1: $n=61$, Lot 2: $n=92$ and Lot 3: $n=48$ ). Each dot represents the data from a single infected fish. $\mathrm{CI}_{95 \%}=[0.1236,0.3893] . \mathrm{r}_{\mathrm{s}}=$ Spearman correlation coefficient $(p<0.05)$. 

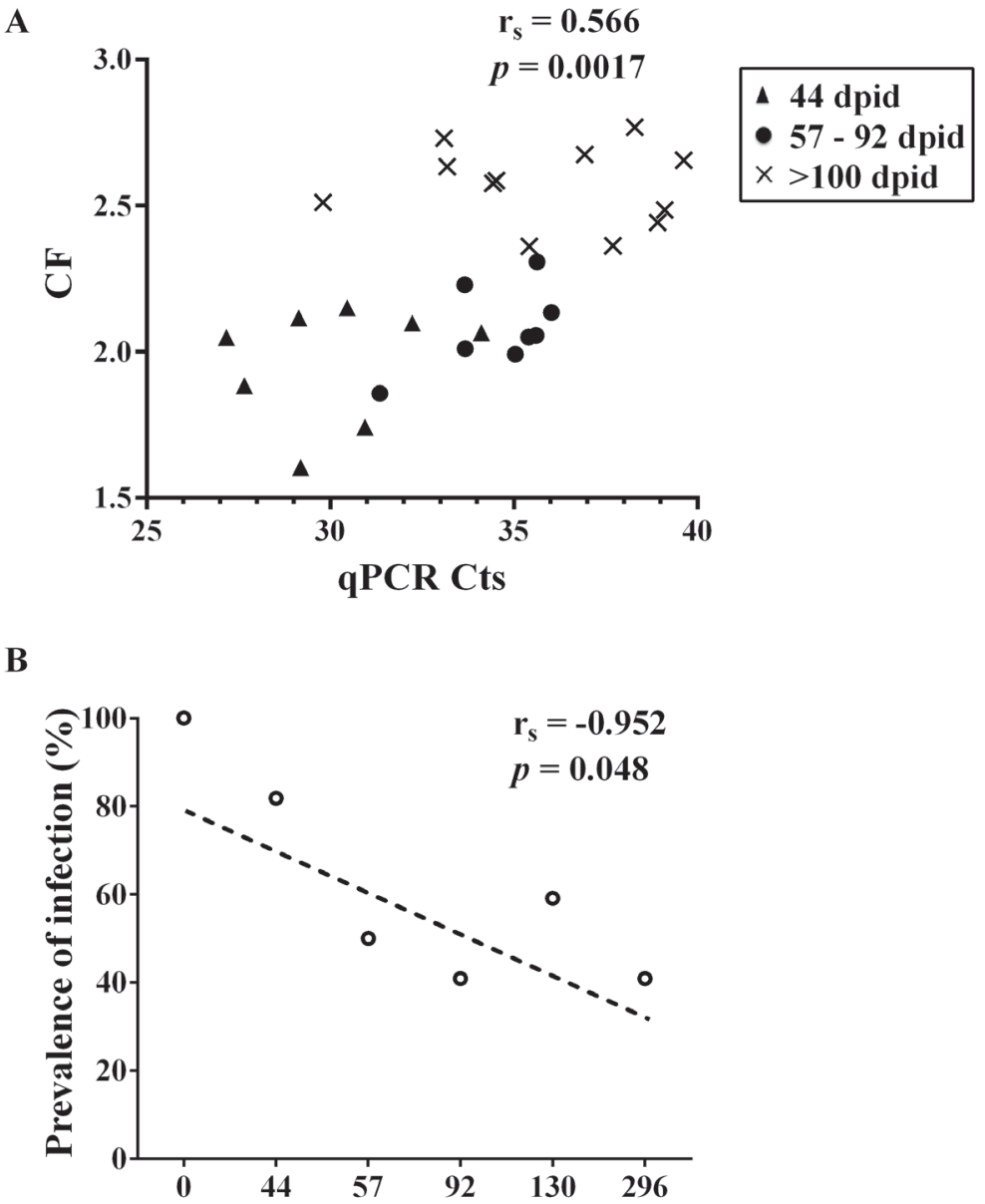

Days post-initial detection

Figure 2. Enterospora nucleophila-infected fish from a stock with $100 \%$ prevalence and high intensity (Lot 3) were maintained in the laboratory up to 296 days post-initial detection (dpid) and sampled periodically. Correlation between intensity of infection (qPCR Ct values) and fish body condition factor (CF) in samples grouped by sampling period in days after initial infection (dpid) (A), represented as different shape-coded symbols $(n=28) . \mathrm{CI}_{95 \%}=[0.2673,0.7713]$. In spite of the mortality bias, the data illustrates a recovery trend in surviving fish. Prevalence of infection decreases with time along the study (B). In B, each dot represents the infection prevalence (based on qPCR) at a given sampling point. The dotted line represents the trend across time. $\mathrm{CI}_{95 \%}=[-0.999,1.086] . \mathrm{r}_{\mathrm{s}}=$ Spearman correlation coefficient $(p<0.05)$.

\section{Mortality}

In the three lots, mortality started upon arrival of the fish to the IATS facilities and reached $50 \%$ or more in a minimum period of 82 days (Table 1 ).

\section{Other disease signs}

Most fish with high infection levels exhibited cachexia, emaciation and lethargy. Cases of extreme cachexia were clearly visible from a dorsal view (Figure 3A).

At necropsy, internal organs appeared pale, and the intestine was thinned and transparent and frequently contained clear or greenish fluid and white faeces in the terminal portion (Figure 3B). Occasionally, ascites was present. 

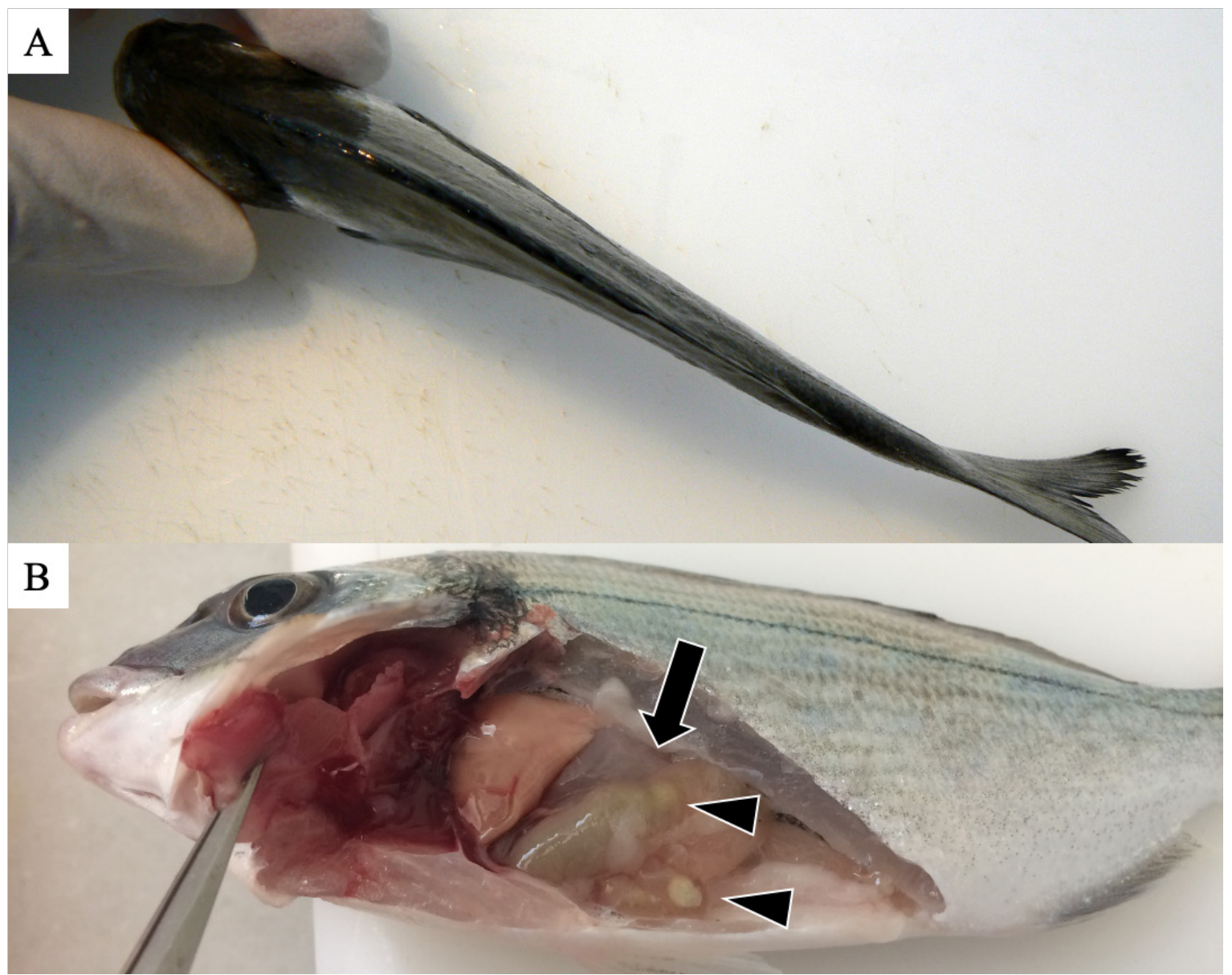

Figure 3. Enterosporora nucleophila infection in gilthead sea bream. In A, an infected fish with extreme cachexia and anorexia. In B, thinned and transparent intestinal walls (arrow) and white faeces in the terminal portion (arrowheads).

Table 1. Data from the initial status of Enterospora nucleophila-naturally infected gilthead sea bream and the cumulated mortality in three different lots (L). Diagnosis was done by qPCR except in *, by histology.

\begin{tabular}{l|c|c|c} 
& L-I & L-II & L-III \\
\hline $\begin{array}{l}\text { Prevalence of } \\
\text { infection at arrival (\%) }\end{array}$ & $30^{*}$ & 100 & 100 \\
\hline Mortality (\%) & 100 & 54.8 & 50 \\
\hline Period (days) & 152 & 79 & 82
\end{tabular}

\subsubsection{Location of E. nucleophila in the host}

Intestinal samples of a subset of fish $(\mathrm{n}=20)$ from clinically diseased gilthead sea bream were selected at an enzootic farm were tested by qPCR for the $E$. nucleophila SSU rDNA gene. The data showed individual-animal differences in the distribution of E. nucleophila along the intestine. In general, the anterior intestine 
had the highest prevalence (75\%), whereas posterior and middle intestine segments had lower prevalences (70\% and 65\% respectively). Ct values obtained for anterior intestine segments were also, on average, lower, indicating higher intensity of infection (average Ct of 28.37, vs 29.82 for middle intestine, and 30.29 for anterior intestine), and this pattern was present in most fish presenting moderate to high infection levels. However, individual patterns varied widely, and only a wholeintestine homogenate could reveal the true prevalence of the stock (100\%).

The presence of blood stages was confirmed by qPCR in 44\% of a panel of samples from fish with a positive qPCR test for the intestine $(n=63)$. However, the average Ct values of blood samples were much higher $(36.47 \pm 0.49$, vs. $30.16 \pm 1.19$ at the intestine), and often close to the routine positive cut-off value of 38 . Indeed, when taking $\mathrm{Ct}=40$ as a positive cut-off value, $100 \%$ of these blood samples were positive. E. nucleophila was detected by qPCR in organs other than intestine sampled over a 296 dpid period ( $\mathrm{n}=41$, Lot 3; Figure 4). At the time of initial diagnosis, this stock had $100 \%$ prevalence based on qPCR of the intestine. E. nucleophila infection tended to become more prevalent in the stomach and especially in the haemopoietic tissues (spleen and head kidney) later in the infection. In the last sampling point (296 dpid), $100 \%$ of the sampled fish $(\mathrm{n}=21)$ were positive in spleen and head kidney and $95 \%$ in the stomach. In general, as observed with blood samples, samples from organs other than the intestine had relatively high $\mathrm{Ct}$ values. For gall bladder samples only 2/41 samples were positive $\mathrm{Ct}=35.9$ and 37.8) during the study period. At the last sampling (296 dpid), the infection intensity of haemopoietic tissues was similar or higher than those of intestine (i.e., head kidney samples mean $\mathrm{Ct}=33.69 \pm 0.652$; spleen: $\mathrm{Ct}=33.80 \pm 0.258$; stomach: $\mathrm{Ct}=34.15 \pm 1.03$; intestine $\mathrm{Ct}=34.38 \pm 2.06$ ).

In contrast to this increase in the prevalence of infection in stomach and haemopoietic organs, the prevalence in the intestine declined to $50 \%$ in the first $92 \mathrm{dpid}$, and to 38\% at the last sampling (Figure 4). All individuals with detectable infection in non-digestive organs also tested positive somewhere in the digestive tract in the first samplings up to $130 \mathrm{dpid}$. In contrast, at the last sampling point (296 dpid), detection in non-digestive organs did not always coincide with detection in the digestive tract. 


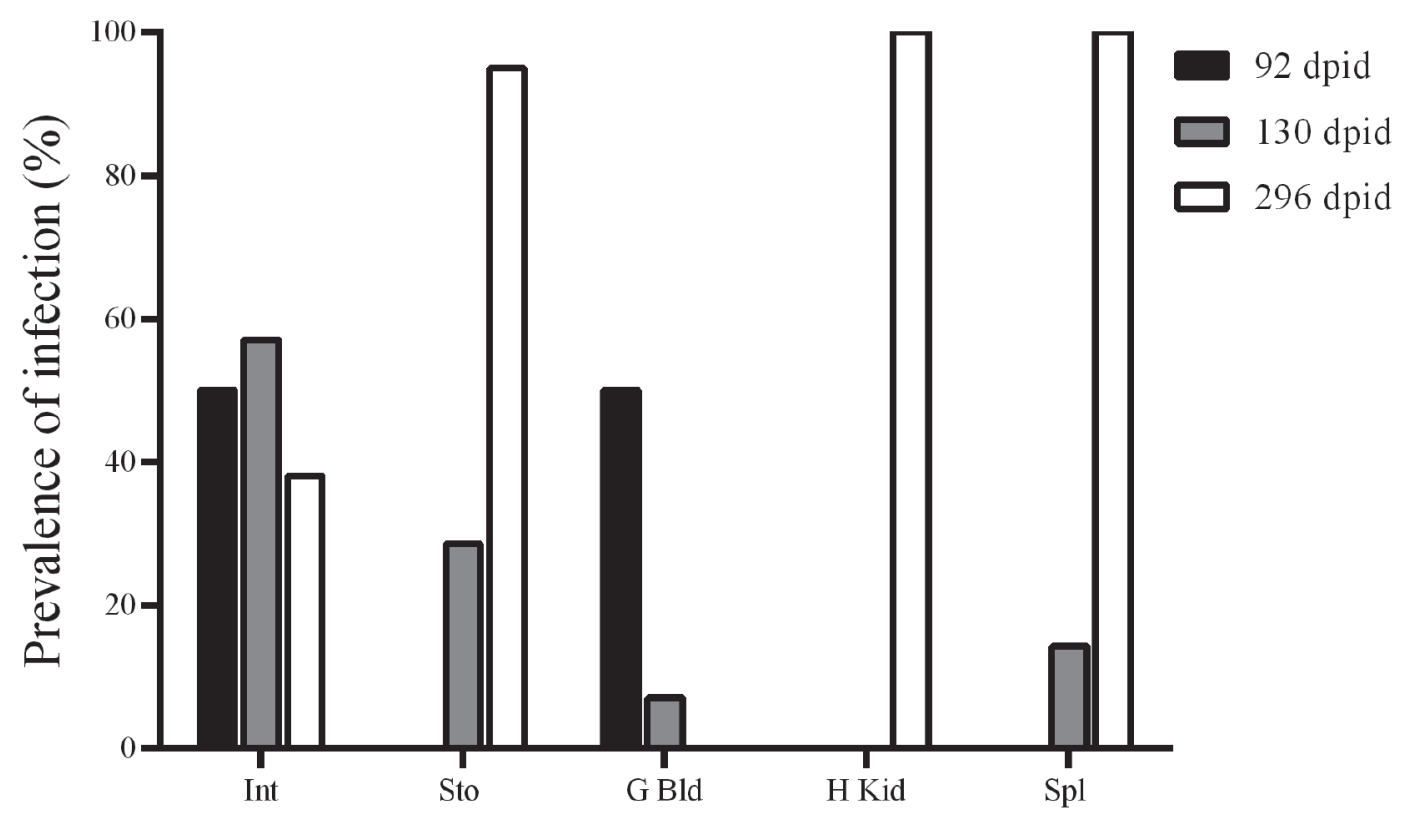

Figure 4. Prevalence of Enterospora nucleophila infection determined by qPCR in different organs from naturally infected fish maintained at the laboratory and sampled periodically up to 296 days post-initial detection (dpid) of infection in the lot of fish. Sto = stomach; Int = intestine; $\mathrm{G}$ bld = gall bladder; $\mathrm{H} \mathrm{Kid} \mathrm{=} \mathrm{head}$ kidney; Spl = spleen.

\subsubsection{Histopathology}

\section{Clinically infected fish}

We include in this category fish in which the parasite is clearly detectable by histology (conventional and/or CW-stained specimens), normally in large amounts and mainly in the intestinal epithelium. The most obvious histopathological alteration observed in the intestine is hypercellularity, including superabundant rodlet cells occupying the epithelium and disorganizing the normal appearance of the palisade. At a later stage, the parasite is also localized in intracytoplasmic position in rodlet cells, enterocytes and macrophages, either in the epithelium or the submucosa. The nucleus of infected cells can appear pyknotic, sometimes with karyorrhexis and eventually with karyolysis. This seems to trigger an intense host cellular reaction, with lymphocyte infiltration at the base of the epithelium and EGC frequently seen between enterocytes. This profile is typical of infected fish sampled in the farms in winter. In these fish, it was frequent to see host cells harbouring spores in the cytoplasm being shed to the gut lumen, and microsporidian spores released from them (Figure 5A-K). 

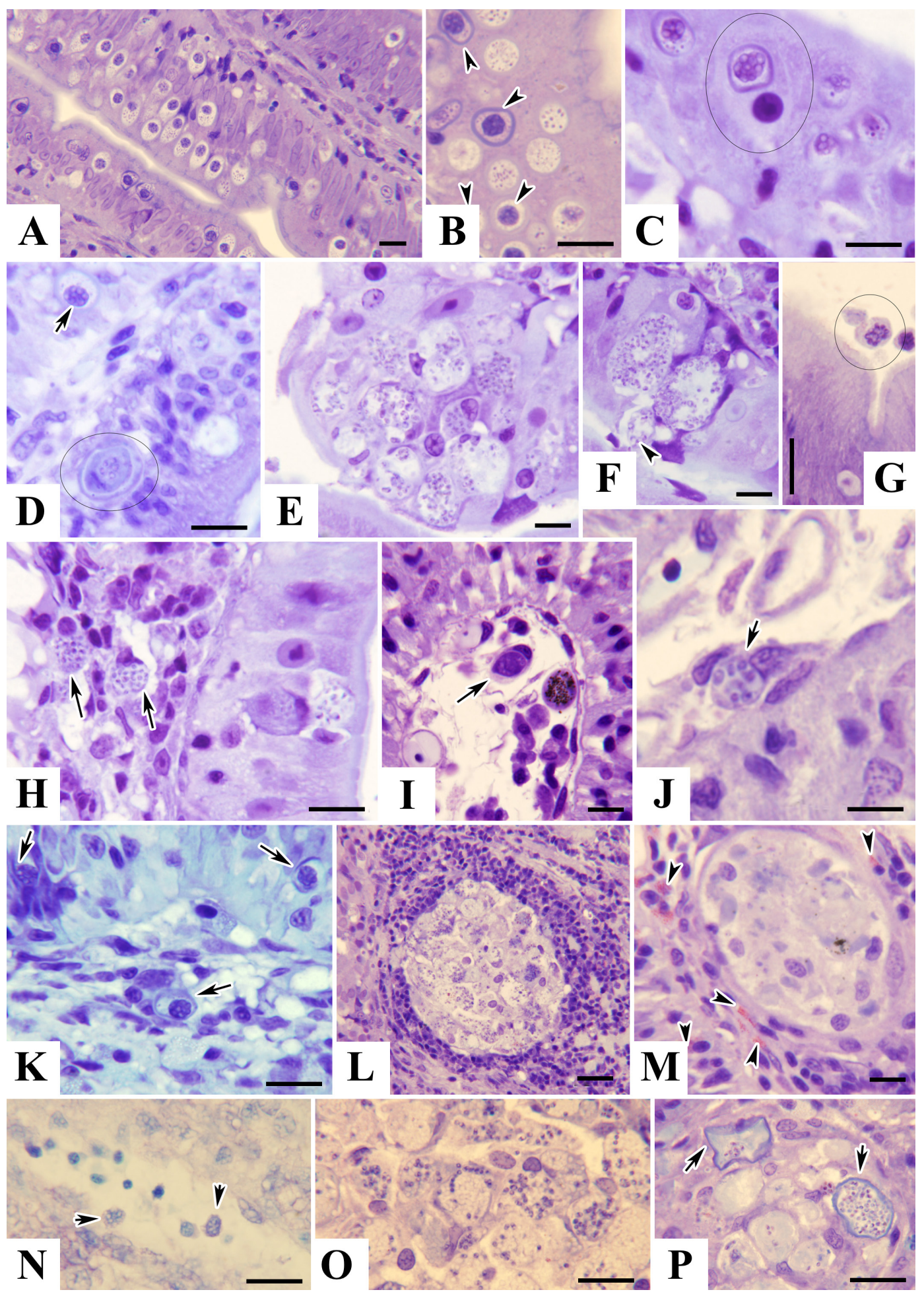

Figure 5. Photomicrographs from histological resin sections of intestines of gilthead sea bream severely infected by Enterospora nucleophila. Epithelial layer with parasitic stages, in intranuclear position in rodlet cells (A-D) and in intracytoplasmic location (E,F). Spores are shed free to the gut lumen (arrowhead in F) or still within host cells and not fully matured (G). Macrophages can engulf infected cells in the epithelium (C,D) and become infected in the submucosa (H), blood vessels (I,J), harbouring spores (H,J) and merogonial stages (I). Infected rodlet cells can be seen even in the submucosa (K). Macrophage aggregates full of spores are often surrounded by lymphocytes (L) and eosinophilic granular cells (M). Foamy macrophages (O) are abundant within the aggregates, and eventually destroy the parasite $(\mathrm{P})$ and only residues are left, remnants of the walls of infected rodlet cells $(\mathrm{P})$ are sometimes visible. Blood cells with initial merogonical stages are seldom observed $(\mathrm{N})$ within blood vessels. Bar scales $=10 \mu \mathrm{m}$ all except $\mathrm{L}=20 \mu \mathrm{m}$. Staining = Giemsa. 
In a subsequent stage, macrophage aggregates containing spores are seldom found in the epithelium but frequently in the submucosa, normally being surrounded by a first cuff of lymphocytes and second one of granulocytes, very rarely encapsulated by fibrocytes, and seldom with melanin deposits. At this point, the submucosa displays hyperplasia with strong infiltration of granulocytes, and even the intestinal serosa can harbour granulomas. In a further step, macrophage aggregates become larger, full of foamy macrophages with ingested spores, and sometimes seem to harbour residues of infected rodlet cells. These aggregates eventually turn into granulomata with necrotic foci, filled with parasite residues, which can be barely recognised. In parallel, dead epithelial cells can also become vacuolated or necrotic, and the epithelium appears full of cellular debris (Figure 5L-P).

\section{Non-clinically diseased fish}

Fish positive by qPCR, but with no parasite stages detected by conventional histology showed however clear histopathological alterations at the intestinal level. This pattern was commonly observed in fish with high $\mathrm{Ct}$ values. The most remarkable histopathological observation was again a conspicuous hypercelularity of the epithelium, even at low magnification, which displays high numbers of epithelial cells with large nuclei and anomalous chromatin. Occasionally, merogonial stages could be confirmed within these nuclei. Vacuolated cells, empty or with cell debris, are very common. In some cases, rodlet cells are abundant, especially at the posterior segment of the intestine. Like in clinically diseased fish, hyperplasia of the submucosa and infiltration of lymphocytes, EGC and early macrophage aggregates (Figure 6A-N), were commonly observed. These signs were interpreted as an important host reaction leading to the destruction of the parasite in those fish that did not die (typical profile of fish in spring), in which the disease did not progress. This late stage corresponded to fish in which the parasite was found also by qPCR in haematopoietic organs, such as spleen and head kidney, in which macrophages with parasite residues accumulated. 

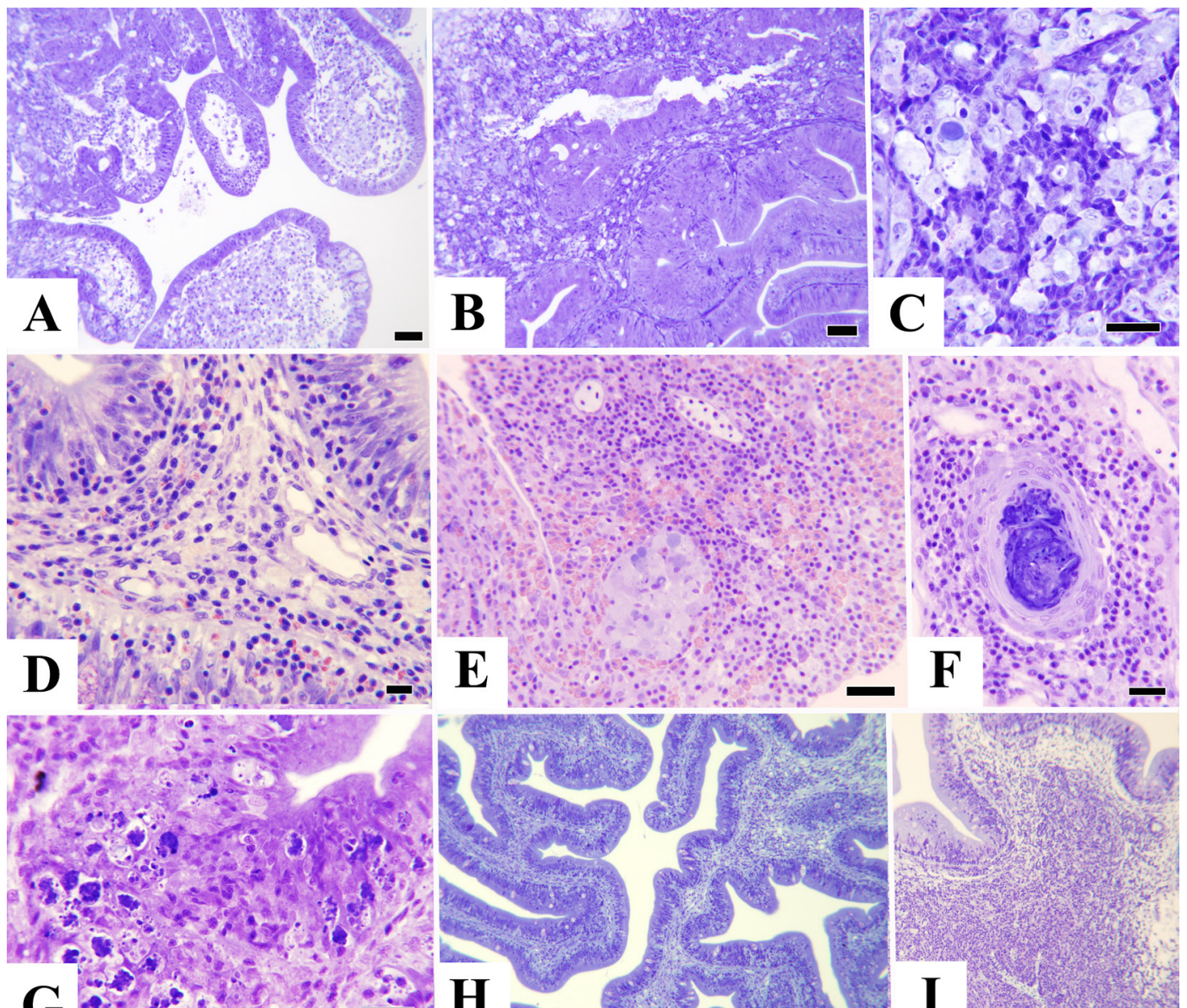

$\mathbf{E}$ \% $\cdots$
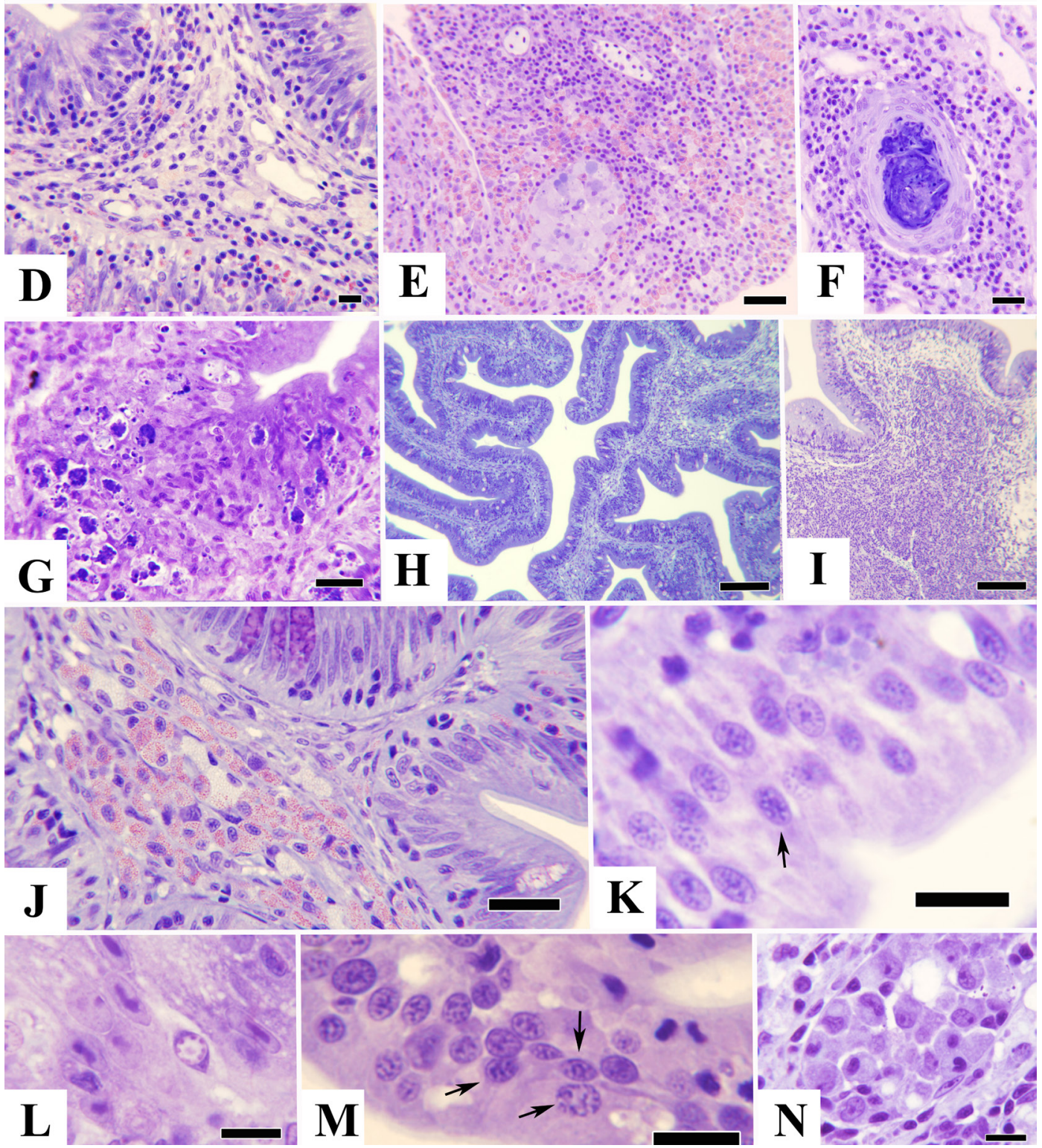

Figure 6. Photomicrographs from histological resin sections of intestines of gilthead sea bream, severely infected by Enterospora nucleophila (A-G) or non-showing clinical signs (H-N). Note the vacuolated epithelium (A) and the hyperplasic submucosa (A,B) full of macrophages (C) or eosinophilic granular cells (EGC) (D). Macrophage aggregates can be seen even in the serosa, surrounded by abundant EGC (E), or forming necrotic granuloma (F) in the submucosa. Necrosis of can be seen also in the epithelium (G). Hypercelullarity in epithelium (H) and hyperplasia of submucosa (I), sometimes with great proliferation of EGC (J). Aberrant nuclei with anomalous chromatin is very frequent in the epithelium, only some these nuclei harbour parasitic stages (arrows in K-M). Incipient macrophage aggregates can be seen in the submucosa (N). Bar scales $=10 \mu \mathrm{m}$ $(\mathrm{C}, \mathrm{D}, \mathrm{K}-\mathrm{N}) ;=20 \mu \mathrm{m}(\mathrm{E}-\mathrm{G}, \mathrm{J}) ;=50 \mu \mathrm{m}(\mathrm{A}, \mathrm{B}) ;=100 \mu \mathrm{m}(\mathrm{H}, \mathrm{I})$, Staining = Giemsa. 


\subsubsection{Cellular immune response}

Immunohistochemistry showed that mast cells were the main type of granulocyte forming the cellular inflammatory infiltrate in the submucosa and mucosa. Very few acidophilic granulocytes were present, even in severe inflammatory infiltrates (Figure 7A, B). RNA-ISH labelled IgM and IgT transcripts in cells in the submucosa when intracytoplasmic stages of E. nucleophila were present, and the labelled cells were sometimes in close proximity to the spores. IgT-expressing cells were particularly abundant in the anterior intestine and even infiltrated in the mucosa in contact with infected cells. IgT- and IgM-expressing cells were also abundant around macrophage aggregates in the submucosa (Figure 7C-G).

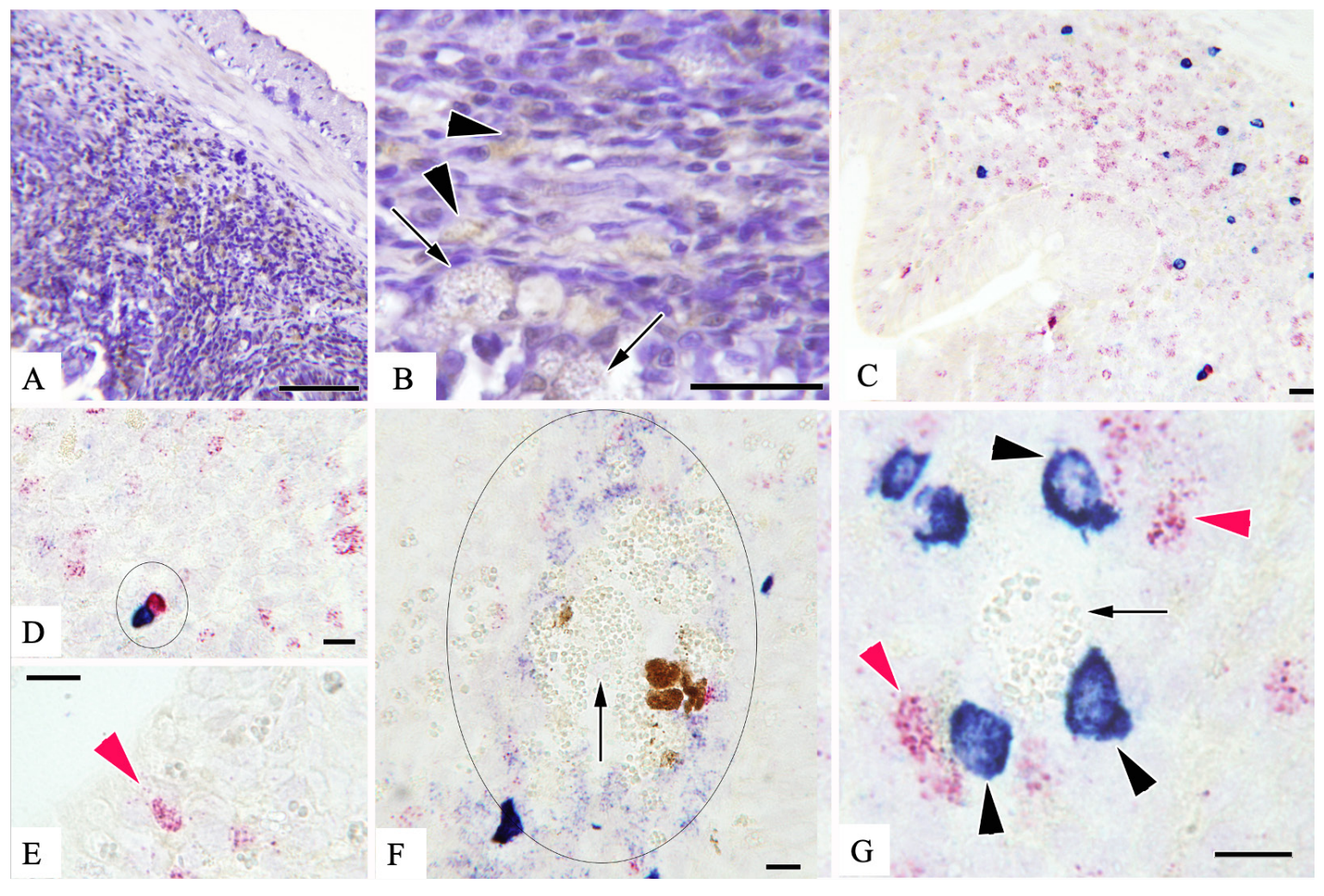

Figure 7. Photomicrographs from histological paraffin sections of intestines of gilthead sea bream severely infected by Enterospora nucleophila. Abundant mastocites (stained brown with anti-histamin antibody, arrowheads in A and B) can be seen in the submucosa of anterior intestine. Arrows point to groups of spores in the epithelium. In situ hybridization staining of IgM (blue) and IgT (fuchsia) expressed in the anterior segment (C-G). Black arrowheads point to some IgM+ cells and red arrowheads point to some IgT+ cells. Notice the presence of IgT transcripts in the epithelium (C-E). Arrows point to parasite spores in F and G. The circle in F delimits a MMC surrounded by IgM+ cells, and the circle in D corresponds to a pair of IgM-IgT + cells touching each other in the submucosa. Bar scales $=10 \mu \mathrm{m}(\mathrm{D}-\mathrm{G}) ;=20 \mu \mathrm{m}(\mathrm{B}, \mathrm{C}) ;=50 \mu \mathrm{m}(\mathrm{A})$. 


\subsection{DISCUSSION}

Gilthead sea bream with severe E. nucleophila infection had arrested growth, emaciation, and thinned intestinal walls. These findings are similar to those recently described in juvenile groupers infected with a related intranuclear enteric microsporidian, including severe emaciation, anorexia, and intestinal oedema with whitish content and a thin transparent wall (Xu et al., 2017). D. lepeophtherii infection of Atlantic salmon was previously reported exclusively in the gills and skin, but more recent intestinal infections were associated with ascites, hyperemia and often peritonitis, among other signs (Weli et al., 2017). Whitish faeces are also frequently seen in gilthead sea bream affected by the myxozoan Enteromyxum leei or the coccidian Cryptosporidium molnari (Âlvarez-Pellitero \& Sitjà-Bobadilla, 2002). Therefore, these signs are not specific for microsporidiosis but common to enteric microparasites affecting feed intake and disrupting intestinal functions such as digestion and absorption of nutrients and minerals and osmotic balance. In the present study, whitish faeces from naturally infected gilthead sea bream were qPCR-positive for E. nucleophila (data not shown), suggesting that contamination of the water by faeces is possible.

Stunted growth is a characteristic of this disease (Palenzuela et al., 2014). In the current study, the body weight of naturally infected fish was approximately half that of the unaffected stock at the farm. Indeed, an abnormally high coefficient of variation in the routine biometrical check-points appears as one of the presumptive indicators of this infection. In addition, a statistically significant relationship between infection intensity and body condition factor was found in the entire dataset of infected fish sampled during 3 different outbreaks. Stunted growth and poor body condition factor are nonspecific signs and they may also be caused by inadequate diets or feeding regimes, or by other diseases such as enteromyxosis (Sekiya et al., 2016; Sitjà-Bobadilla \& Palenzuela, 2012). Growth arrest is common in microsporidian infections, partly due to the induced anorexia. In this study, the specific growth rate in one lot of infected fish was only $1 / 6$ that of normal fish. By comparison, the average weight of moribund grouper infected by an enteric microsporidian was $20-40 \%$ of that for uninfected fish, and D. lepeophtherii-infected Atlantic salmon weighed only 20-25\% of normal growing fish (Weli et al., 2017; Xu et al., 2017). In rainbow trout experimentally infected with Loma salmonae, the onset of significant growth rate suppression was associated with the appearance of gill lesions (Speare et al., 1998), with xenoma onset, and accompanied by a reduction in feed intake (Ramsay et al., 2004). Zebrafish (Danio rerio) experimentally infected with Pseudoloma neurophilia also had a reduced size (Ramsay et al., 2009). Therefore, the economic losses due to E. nucleophila are potentially significant not only due to mortality (which was low to moderate in the sea cages), but more importantly to the severely stunted growth. 
In vertebrate and invertebrate hosts, cell-mediated immunity confers protection against microsporidians and the key mechanisms are phagocytosis and encapsulation (Ghosh \& Weiss, 2012; Pan et al., 2018; Valencakova \& Halanova, 2012). Most information on fish immune responses against microsporidia is based on xenoma-forming species (reviewed in Rodriguez-Tovar et al., 2011) and very little is known about intranuclear species. In the current study, the cellular immune response of gilthead sea bream was very mild or absent when E. nucleophila was intranuclear in the intestinal mucosa. In this circumstance, hypercellularity of the mucosa (detected at low magnification) was the main histologic lesion. The cellular immune response apparently started when E. nucleophila was located in the cytoplasm of the host cells and/or when it passed into the submucosa. At that point, macrophages and mast cells predominated, as shown by histology and immunohistochemistry, whereas acidophilic granulocytes, equivalent to mammalian neutrophils (Chaves-Pozo et al., 2004), seemed to be depleted, similar to that reported in E. leei infections (Estensoro et al., 2014). This picture is similar to other fish microsporidia in which the inflammatory response is triggered when xenomas rupture, leading to severe, persistent and extensive cellular proliferation, like in Loma salmonae gill infections in salmonids (Becker \& Speare, 2007). Conversely, in other microsporidians, such as Spraguea in the Japanese anglerfish, even heavy infections of the nervous system had no associated lesions (Freeman et al., 2011). There were high number of IgT-expressing cells in the intestine, particularly the anterior segment, and these cells were distributed across the epithelium and in close proximity to the microsporidia. The abundance of these cells would be in line with the mucosal role of IgT described for teleosts (Zhang et al., 2010), and could suggest a role of this immunoglobulin in the local response to E. nucleophila.

Foamy macrophages are laden with lipid generated from the massive uptake of modified low-density lipoproteins and the intracytoplasmic accumulation of cholesteryl esters. Foam cells can also be generated as a consequence of infection by persistent pathogens such as Mycobacterium, Chlamydia and Toxoplasma in humans and other mammals (Valledor et al., 2015). These foamy macrophages have been described in other microsporidioses, such as in AIDS patients with Encephalitozoon intestinalis infection in the lamina propria (Liberman \& Yen, 1997). Foamy macrophages containing numerous intracytoplasmic microsporidia were also observed in granulomatous infiltrates of parrots (Gelis \& Raidal, 2006). In fish, macrophages with foamy cytoplasm have been described ingesting spores of a microsporidian parasite causing liquefaction of the skeletal muscle of the Norway pout, Trisopterus esmarkii (Pulsford \& Matthews, 1991), and in infiltrations in gut, spleen, kidney, heart, liver, gill and dermis of D. lepeophtheriiinfected Atlantic salmon (Weli et al., 2017). The foamy macrophages that harbour microsporidial stages seem resistant to degradation and it is thought that when 
the immune system is unable to eliminate substances perceived as foreign, it produces a granuloma encapsulated by fibroblasts, attempting to wall off the nonself-material. The granuloma is therefore typical of fish in a late stage of this disease. The role of macrophages in resistance and clearing of fish microsporidian spores has been described, but some parasites are capable of blocking the intracellular killing mechanisms of phagocytes (Rodriguez-Tovar et al., 2011), thus avoiding destruction by immune cells. In fact, it has been suggested that $P$. theridion-infected macrophages could be responsible for propagating the parasite within the host (Sveen et al., 2012). The current study confirms the dual role of macrophages. On one hand, the observation of different viable parasite stages within macrophages in the intestinal mucosa and submucosa, and in blood vessels, suggests these cells may act as "Trojan horses". On the other hand, as the observation of parasite debris within macrophage aggregates suggest that they may combat the parasite in the last stages of the infection, perhaps acting in antigen presentation and attracting other leukocytes. This latter role is also in line with the accumulation of macrophages as well as higher detection of the parasite by qPCR in spleen and head kidney during the late stage of infection. The survival of microsporidians within macrophages has already been described for other species, as they have evolved mechanisms that allow them to resist destruction within macrophages. For example, phagolysosome formation is prevented by Glugea hertwigi (Weidner \& Sibley, 1985), and Enterocytozoon cuniculi is capable of surviving despite the host's active immune response. Latent asymptomatic infections may persist as long as multiplication of the microsporidian and the immune response are in equilibrium (Valencakova \& Halanova, 2012). In the subset of fish from a naturally-infected stock sampled periodically along 296 days in this study, a progressive partial recovery from the infection was noted. Although the data are likely biased by the mortality observed in the stock, a clear decrease in the prevalence from the $100 \%$ initial value was still obvious. In addition, infected fish in this stock presented, on average, a much lower intensity and a recovered body condition factor by the end of the follow-up period. This notwithstanding, the presence of fish harbouring the parasite, even if in small numbers, 10 months after an outbreak, it is remarkable and can have obvious epidemiological implications. It is currently unknown if these patterns correspond to a full -recovery stage or to cover infections from which the infection could relapse (Ahmed et al., 2019).

Besides the severe disease signs, E. nucleophila can cause extensive histopathological changes in acute cases, even when present at lower levels (only detectable by qPCR) in fish that do not show disease signs. Similarly, PCR showed the presence of $N$. cyclopteri in most organs of apparently healthy lumpfish (Freeman et al., 2013). The existence of non-symptomatic carriers has relevant consequences for the spread of the disease, and early detection of E. nucleophila in non-diseased fish may be useful to prevent further dissemination of infection within farmed stocks, or to avoid stressful handling of the fish that could trigger clinical disease. 
E. nucleophila was detected in blood, but its pathological significance is difficult to ascertain. Blood samples were PCR-positive for E. nucleophila in only $44 \%$ of clinically infected fish from the farms. This finding suggests hematogenous dissemination of E. nucleophila within the host. This opens the possibility of cryptic or dormant E. nucleophila life stages in other organs as described for Loma salmonae (Sánchez et al., 2000; Speare et al., 1999). However, in-depth examination of diseased fish including ISH was not conclusive (Ahmed et al., 2019). Experimental infections and time-lapse sequential samplings may be needed to properly determine the presence of E. nucleophila life stages in blood and extraintestinal organs.

Several members of the Enterocytozonidae family have a remarkable impact on aquatic hosts. Pre-stocked ponds of cultured prawns in Thailand had a high prevalence of Enterocytozoon hepatopenaei, with the resultant economic losses due to slowed growth and early harvest estimated at \$32,000 per hectare in every culture cycle (Herrero, 2017). There are no economic estimates on the impact of $E$. nucleophila in the culture of gilthead sea bream.

\section{ACKNOWLEDGMENTS \& FUNDING}

The authors kindly acknowledge the collaboration of anonymous fish farming companies allowing access to the animals during the disease outbreaks. We thank J. Monfort and L. Rodríguez for the technical assistance on histological processing.

This work has been carried out with financial support from the European Union and the Spanish MINECO under grant projects ParaFishControl (H2020-634429) and AGL2013-R-48560-C2-2-R, respectively. APS was contracted under ParaFishControl project, RDP was contracted under the PTA-Program from the Spanish Ministry of Science, Innovation and Universities (PTA2018-015315-I), and MCP under CSIC PIE Project No. 201740E013. NHA was the recipient of a fellowship from the Egyptian Cultural Office in Spain. 
CHAPTER 5 


\section{Bibliography}


Ahmed N. H., Caffara M., Sitjà-Bobadilla A., Fioravanti M. L., Mazzone A., Aboulezz A. S., Metwally A. M., Omar A. M., Palenzuela O. (2019) Detection of the intranuclear microsporidian Enterospora nucleophila in gilthead sea bream by in situ hybridization. J Fish Dis. 42:809-815.

Álvarez-Pellitero P., Sitjà-Bobadilla A. (2002) Cryptosporidium molnari n. sp. (Apicomplexa: Cryptosporidiidae) infecting two marine fish species, Sparus aurata L. and Dicentrarchus labrax L. Int J Parasitol. 32:1007-1021.

Becker J. A., Speare D. J. (2007) Transmission of the microsporidian gill parasite, Loma salmonae. Anim Health Res Rev. 8:59-68.

Bravo S. (1996) Enterocytozoon salmonis in Chile. Am Fish Soc. (FHS Section Newsletter). 24:12-13.

Brown M. J. F. (2017) Microsporidia: An Emerging Threat to Bumblebees?. Trends Parasitol. 33:754-762.

Caffara M., Sirri R., Mandrioli L., Gustinelli A., Fioravanti M. (2014) Sindrome emaciativa da Enterospora nucleophila (Microsporidia) in orate (Sparus aurata) allevate in Italia. Proceedings of the XX Convegno Nazionale SIPI. Pisa, Italy. pp. 44.

Cali A., Takvorian P. M. (2014) Developmental morphology and life cycles of the Microsporidia, in: Weiss L. M., Becnel J. J. (Eds). Microsporidia: Pathogens of Opportunity. Wiley-Backwell, Ames, Iowa, USA. pp. 71-133.

Chaves-Pozo E., Pelegrín P., García-Castillo J. (2004) Acidophilic granulocytes of the marine fish gilthead seabream (Sparus aurata L.) produce interleukin-1b following infection with Vibrio anguillarum. Cell Tissue Res. 316:189-195.

Didier E. S., Weiss L. M. (2011) Microsporidiosis: Not just in AIDS patients. Curr Opin Infect Dis. 24:490-495.

Elston R. A., Kent M. L., Harrell L. H. (1987) An intranuclear microsporidium associated with acute anemia in chinook salmon, Oncorhynchus tshawytscha. J Eukaryot Microbiol. 34:274-277.

Estensoro I., Mulero I., Redondo M. J., Álvarez-Pellitero P., Mulero V., Sitjà-Bobadilla A. (2014) Modulation of leukocytic populations of gilthead sea bream (Sparus aurata) by the intestinal parasite Enteromyxum leei (Myxozoa: Myxosporea). Parasitology. 141:425-440.

Freeman M. A., Yokoyama H., Osada A., Yoshida T., Yamanobe A., Ogawa K. (2011) Spraguea (Microsporida: Spraguidae) infections in the nervous system of the Japanese anglerfish, Lophius litulon (Jordan), with comments on transmission routes and host pathology. J Fish Dis. 34:445-452.

Freeman M. A., Kasper J. M., Kristmundsson Á. (2013) Nucleospora cyclopteri n. sp., an intranuclear microsporidian infecting wild lumpfish, Cyclopterus lumpus L., in Icelandic waters. Parasit Vectors. 6:49.

Gelis S., Raidal S. R. (2006) Microsporidiosis in a flock of tricolor parrot finches (Erythrura tricolor). Vet Clin North Am Exot Anim Pract. 9:481-486.

Genersch E. (2010) Honey bee pathology: Current threats to honey bees and beekeeping. Appl Microbiol Biotechnol. 87:87-97.

Ghosh K., Weiss L. M. (2012) T cell response and persistence of the microsporidia. FEMS Microbiol Rev. 36:748-760.

Gupta S. K., Hossain Z., Nanu M. M., Mondal K. (2016) Impact of microsporidian infection on growth and development of silkworm Bombyx mori L. (Lepidoptera: Bombycidae). Agricult Nat Res. 50:388-395.

Han B., Weiss L. M. (2017) Microsporidia: Obligate intracellular pathogens within the fungal kingdom. Microbiol Spectr. 5:10.

Hassan N., Lim Y. A. L., Mahmud R., Shaharuddin N. M., Sulaiman W. Y. W., Ngui R. (2018) Microsporidia infection among various groups of the immunocompromised patients. Trop Biomed. 35:521-530.

Herrero A. (2017) Microsporidians: A macro problem in aquaculture. The Fish Site (https://thefishsite.com/ articles/microsporidians-a-macro-problem-in-aquaculture), $5 \mathrm{~m}$ Publishing (accessed November 2019).

Kent M. L., Shaw R. W., Sanders J. L. (2014) Microsporidia in Fish, in: Weiss L. M., Becnel J. J. (Eds.) Microsporidia: Pathogens of Opportunity. Wiley-Backwell, Ames, Iowa, USA. pp. 493-520.

Liberman E., Yen T. S. (1997) Foamy macrophages in acquired immunodeficiency syndrome cholangiopathy with 
Encephalitozoon intestinalis. Arch Pathol Lab Med.121:985-988.

Lom J. (2002) A catalogue of described genera and species of microsporidians parasitic in fish. Syst Parasitol. 53:81-99.

Lom J., Dyková I. (2005) Microsporidian xenomas in fish seen in wider perspective. Folia Parasitol. 52:69-81.

Morado J. F. (2011) Protistan diseases of commercially important crabs: A review. J Invertebr Pathol. 106:27-53.

Nylund S., Nylund A., Watanabe K., Arnesen C. E., Karlsbakk E. (2010) Paranucleospora theridion n. gen., n. sp. (Microsporidia, Enterocytozoonidae) with a life cycle in the salmon louse (Lepeophtheirus salmonis, Copepoda) and Atlantic salmon (Salmo salar). J Eukaryot Microbiol. 57:95-114.

Palenzuela O., Redondo M. J., Cali A., Takvorian P. M., Alonso-Naveiro M., Álvarez-Pellitero P., Sitjà-Bobadilla A. (2014) A new intranuclear microsporidium, Enterospora nucleophila n. sp., causing an emaciative syndrome in a piscine host (Sparus aurata), prompts the redescription of the family Enterocytozoonidae. Int J Parasitol. 44:189-203.

Pan G., Bao J., Ma Z., Song Y., Han B., Ran M., Li C., Zhou Z. (2018) Invertebrate host responses to microsporidia infections. Dev Comp Immunol. 83:104-113.

Pulsford A., Matthews R. A. (1991) Macrophages and giant cells associated with a microsporidian parasite causing liquefaction of the skeletal muscle of the Norway pout, Trisopterus esmarkii (Nilsson). J Fish Dis. 14:67-78.

Ramsay J. M., Speare D. J., Daley J. (2004) Timing of changes in growth rate, feed intake and feed conversion in rainbow trout, Oncorhynchus mykiss (Walbaum), experimentally infected with Loma salmonae (Microspora). J Fish Dis. 27:425-429.

Ramsay J. M., Watral V., Schreck C. B., Kent M. L. (2009) Pseudoloma neurophilia infections in zebrafish Danio rerio: Effects of stress on survival, growth, and reproduction. Dis Aquat. Organ. 88:69-84.

Rychlik W. (2007) OLIGO 7 primer analysis software. Methods Mol Biol. 402:35-60.

Rodriguez-Tovar L. E., Speare D. J., Markham R. J. F. (2011) Fish microsporidia: Immune response, immunomodulation and vaccination. Fish Shellfish Immunol. 30:999-1006.

Sánchez J. G., Speare D. J., Markham R. J. F. (2000) Normal and aberrant tissue distribution of Loma salmonae (Microspora) within rainbow trout, Oncorhynchus mykiss (Walbaum), following experimental infection at water temperatures within and outside of the xenoma-expression temperature boundaries. J Fish Dis. 23:235-242.

Sekiya M., Setsuda A., Sato H., Song K., Han J. K., Kim G. J., Yeo I. K. (2016) Enteromyxum leei (Myxosporea: Bivalvulida) as the cause of myxosporean emaciation disease of farmed olive flounders (Paralichthys olivaceus) and a turbot (Scophthalmus maximus) on Jeju Island, Korea. Parasitol Res. 115:4229-4237.

Shields J. D. (2011) Diseases of spiny lobsters: A review. J Invertebr Pathol. 106:79-91.

Sitjà-Bobadilla A., Palenzuela O. (2012) Enteromyxum species, in: Woo P. T. K., Buchmann K. (Eds.) Fish Parasites: Pathology and Protection. CAB International, Oxfordshire, UK. pp. 163-176.

Speare D. J., Daley J., Markham R. J. F., Sheppard J., Beaman H. J., Sánchez J. G. (1998). Loma salmonae associated growth suppression in rainbow trout (Oncorhynchus mykiss) occurs during early onset xenoma dissolution as determined by in situ hybridization and immunohistochemistry. J Fish Dis. 21:345-354.

Speare D. J., Beaman H. J., Daley J. (1999) Effect of water temperature manipulation on a thermal unit predictive model for Loma salmonae. J Fish Dis. 22:277-283.

Stentiford G. D., Becnel J. J., Weiss L. M., Keeling P. J., Didier E. S., Williams B. A. P., Bjorson S., Kent M. L., Freeman M. A., Brown M. J. F., Troemel E. R., Roesel K., Sokolova Y., Snowden K. F., Solter L. (2016) Microsporidia- Emergent pathogens in the global food chain. Trends Parasitol. 32:336-348.

Sveen S., Øverland H., Karlsbakk E., Nylund A. (2012) Paranucleospora theridion (Microsporidia) infection dynamics in farmed Atlantic salmon Salmo salar put to sea in spring and autumn. Dis Aquat Org. 101:43-49.

Valencakova A., Halanova M. (2012) Immune response to Encephalitozoon infection review. Comp Immunol 
Microbiol. 35:1-7.

Valledor A. F., Lloberas J., Celada A. (2015) Macrophage Foam Cells, in: John Wiley \& Sons Ltd., ed. eLS. Chichester, UK. pp.1-10.

Vergneau-Grosset C., Larrat S. (2016) Microsporidiosis in vertebrate companion exotic animals. J Fungi (Basel). 2:3.

Weidner E., Sibley L. D. (1985) Phagocytized intracellular microsporidian blocks phagosome acidification and phagosome-lysosome fusion. J Protozool. 32:311-317.

Weli S. C., Dale O. B., Hansen H., Gjessing M. C., Rønneberg L. B., Falk K. (2017) A case study of Desmozoon lepeophtherii infection in farmed Atlantic salmon associated with gill disease, peritonitis, intestinal infection, stunted growth, and increased mortality. Parasit Vectors. 10:370-383.

Xu L. W., Liu X. H., Zhang J. Y., Liu G. F., Feng J. (2017) Outbreak of enteric microsporidiosis of hatchery-bred juvenile groupers, Epinephelus spp., associated with a new intranuclear microsporidian in China. J Fish Dis. 40:183-189.

Zhang Y. A., Salinas I., Li J. Parra D., Bjork S., Xu Z., LaPatra S. E., Bartholomew J., Sunyer J. O. (2010) IgT, a primitive immunoglobulin class specialized in mucosal immunity. Nat Immunol. 11:827-835. 


$$
242
$$

242 


\section{Chapter 6}

Experimental horizontal transmission of

Enterospora nucleophila (Microsporea:

Enterocytozoonidae) in gilthead sea bream (Sparus aurata)

Amparo Picard-Sánchez; M. Carla Piazzon; Itziar Estensoro; Raquel del Pozo;

Nahla Hossameldin Ahmed; Oswaldo Palenzuela; Ariadna Sitjâ-Bobadilla

INSTITUTO DE ACUICULTURA TORRE DE LA SAL

CONSEJO SUPERIOR DE INVESTIGACIONES CIENTÍFICAS (IATS-CSIC),

Torre de la Sal s/n 12595 Castellón Spain

(Submitted to 'Animals') 
Control of enteric parasitic diseases of farmed gilthead sea bream 


\subsection{ABSTRACT}

Enterospora nucleophila is a microsporidian enteroparasite, that infects mainly the intestine of gilthead sea bream (Sparus aurata), leading to an emaciative syndrome. Thus far, the only available information about this infection comes from natural outbreaks in farmed fish. The aim of the present study was to determine whether E. nucleophila could be transmitted horizontally using naturally infected fish as donors, and to establish an experimental in vivo procedure to study this hostparasite model without depending on natural infections. Naïve fish were exposed to the infection by cohabitation, effluent, or intubated either orally or anally with intestinal scrapings of donor fish in four different trials. We succeeded in detecting parasite in naïve fish in all the challenges, but the infection level and the disease signs were always milder than in donor fish. The parasite was found in peripheral blood of naïve fish after 4 weeks post challenge (wpc) in oral and effluent routes, and up to $12 \mathrm{wpc}$ in the anal transmission trial. Molecular diagnosis detected $E$. nucleophila in other organs besides intestine, such as gills, liver, stomach or heart, although the intensity was not as high as in the target tissue. The infection tended to disappear through time in all the challenge routes assayed, except in the anal infection route.

\section{Keywords}

Sparus aurata, experimental transmission, Enterospora nucleophila, Teleostei, Microsporidia, aquaculture, temperature, immunosuppression, histopathology. 


\subsection{INTRODUCTION}

Microsporidia are obligate intracellular (intracytoplasmic and/or intranuclear) eukaryotic, spore-forming parasites, which can infect almost all types of animals, from vertebrates (including humans), to invertebrates (Szumowski \& Troemel, 2015). The impact of these parasites in aquaculture, fisheries and fish research facilities has been widely documented (Kent et al., 2014; Lom \& Dyková, 1992; Szumowski \& Troemel, 2015). Despite being extraordinarily widespread and with significant impact on human and livestock health, microsporidian infections are poorly understood.

Microsporidian life cycles consist of two general developmental phases: merogony and sporogony. Meronts multiply inside the infected host cell, eventually forming sporonts and spores, which are ultimately released from the host and transmit the infection. The spore is both the infectious and the resistant stage thanks to its thick chitinous layer (Weiss et al., 2014; Yang et al., 2018). It is extremely resistant to environmental stress and lysis, allowing the organism to maintain viability in the aquatic environment for extended periods (Leiro et al., 2012; Li \& Fayer, 2006; Shaw et al., 2001) and to resist digestive enzymes in the gastrointestinal tract of the hosts. In general, fish microsporidia are transmitted directly, presumably per os, by ingestion of infected tissues or spores present in the water, or through the penetration of the skin (Dunn \& Smith, 2001). Different routes of horizontal transmission have been tested for microsporidia in fish, such as oral intubation (Mc Vicar, 1975; Ramsay et al., 2004; Shaw et al., 1998); cohabitation (Ramsay et al. 2004; Shaw et al., 1998); effluent transmission/bath with parasite stages (Kent \& Bishop-Stewart, 2003; Mc Vicar, 1975; Sanders et al., 2010, 2014); and intracoelomic or intramuscular injections (Matthews \& Matthews, 1980; Mc Vicar 1975; Shaw et al., 1998). Several studies have achieved the direct horizontal transmission such as with Nucleospora salmonis (Baxa et al., 1992), Loma salmonis (Shaw et al., 1998), Glugea anomala (Weissenberg, 1968), Glugea plecoglossi (Lee et al., 2004) or Glugea stephani (Mc Vicar, 1975; Olson, 1976). However, for other microsporidian species, an intermediate host is needed to complete their life cycle (Becnel, 1992; Micieli et al., 2000).

Enterospora nucleophila is an enteric microsporidian that affects mainly the intestine of gilthead sea bream, provoking anorexia, cachexia, and even death (Palenzuela et al., 2014). Recently, a negative correlation between the intensity of E. nucleophila infections and the condition factor (CF) of infected fish has been described (Picard-Sánchez et al., 2020b), which demonstrates the growth arrestment induced by the parasite. The microsporidium is located mainly in the epithelial layer of intestinal mucosa and in the submucosa, infecting the cytoplasm of enterocytes and macrophages and the nucleus of enterocytes and rodlet cells, 
although other organs can be infected (Palenzuela et al., 2014; Picard-Sánchez et al., 2020b). The difficulty of diagnosing this disease, due to the very minute spore size and its intranuclear location, has recently been overcome by the development of qPCR and ISH diagnostic methods, which allow detecting very low infection levels that can be considered negative by histology (Ahmed et al., 2019; PicardSánchez et al., 2020b). Another impediment to study this emerging disease is the difficulty to isolate the minute spores and to obtain an in vitro culture. Therefore, the aim of the current work was to develop an in vivo model of transmission that could provide a source of parasite, to test treatments and prophylactic approaches and to study the host-parasite interactions in depth under controlled conditions.

\subsection{MATERIALS AND METHODS}

\subsubsection{Donors and naïve recipient fish}

Three different lots of gilthead sea bream (GSB) naturally infected with $E$. nucleophila ( $\mathrm{n}=300$ for Lot 1 and $\mathrm{n}=200$ for Lots 2 and 3) were used as donors (D) (Supplementary Table 1). They were harvested from commercial sea cages in the Western Mediterranean Sea and displayed the typical growth arrestment and emaciation signs associated to this microsporidiosis (Palenzuela et al., 2014). The smaller, wasted fish were handpicked and transported alive to the Institute of Aquaculture Torre de la Sal (IATS-CSIC, Castellón, Spain) facilities. Upon arrival, a subsample was sacrificed by overexposure to the anaesthetic (MS-222, $0.1 \mathrm{~g} / \mathrm{L}$; Sigma), and tested for the presence of E. nucleophila in the intestine by qPCR or by histology (see more details below). Donors for each trial were selected from these infected fish stock according to the clinical signs described previously: cachexia, swollen abdominal cavity, and thinned intestinal walls in the necropsy (Palenzuela et al., 2014; Picard-Sánchez et al., 2020b), and these fish were generally positive for $E$. nucleophila by qPCR and histology.

Healthy GSB juveniles from a commercial nursery were used as recipient fish (R), and kept in the same facilities in $5 \mu \mathrm{m}$-filtered and UV-treated sea water (salinity 37.5 $\mathrm{g} / \mathrm{L})$ under natural temperature and photoperiod at our latitude $\left(40^{\circ} 5^{\prime} \mathrm{N} ; 0^{\circ} 10^{\circ} \mathrm{E}\right)$. The absence of E. nucleophila in R stocks was confirmed by qPCR according to PicardSánchez et al. (2020b). Fish were fed ad libitum a commercial diet (BioMar, Palencia, Spain) and they were kept according to the Guidelines of the European Union Council (Directive 2010/63/EU), the Spanish RD 53/2013, and the CSIC National Committee on Bioethics under approval number 2018/VSC/PEA/0240. 


\subsubsection{Samplings and parasite diagnosis}

Before all samplings, fish were starved for two days. Weight and length were registered in all samplings and the condition factor ( $\mathrm{CF}=(100 \times$ body weight) / length ${ }^{3}$ ) was calculated. The prevalence of infection was calculated as the percentage of E. nucleophila-positive fish out of the total of sampled fish in each experimental group.

Parasite diagnosis was carried out as previously described (Ahmed et al., 2019; Palenzuela et al., 2014; Picard-Sánchez et al., 2020b). Briefly, for histology processing, pieces of intestine were fixed in $10 \%$ buffered formalin and embedded in paraffin or in methacrylate resin (Technovit 7100, Kultzer, Wehrheim, Germany). Tissue sections (4-5 $\mu \mathrm{m}$ for paraffin and $1 \mu \mathrm{m}$ for resin samples), were stained with Giemsa or with $0.1 \%$ calcofluor white M2R stain (CW) and 0.1\% Evans blue (Ahmed et al., 2019). Slides were dehydrated, mounted in DPX, and examined using bright-field and fluorescent microscopy under UV excitation light, respectively. In histological slides, parasite infection was evaluated as presence or absence of sporogonial and merogonial stages. Intranuclear infections, typically affecting enterocytes and rodlet cells (RCs), were discriminated from cytoplasmic infections affecting enterocytes and phagocytes at the epithelium and lamina propria submucosa (Ahmed et al., 2019; Palenzuela et al., 2014). Observations were made at 1250x magnification.

Molecular diagnosis was performed by qPCR as previously described (PicardSánchez et al., 2020b). Briefly, non-lethal samples (NL-qPCR) consisted of a sample of rectal mucosa taken from anaesthetised with a cotton swab, and/or 3-4 $\mu \mathrm{L}$ blood samples drawn using 0.5 M EDTA-coated syringes. Both types of NL-qPCR samples were deposited in $200 \mu \mathrm{L}$ of lysis buffer and conserved at $4^{\circ} \mathrm{C}$. Lethal samples (L-qPCR) consisted of small pieces of intestine tissue (50-100 mg) in $200 \mu \mathrm{L}$ of lysis buffer, or an aliquot (100-200 $\mu \mathrm{L}$ ) of tissue homogenate in Tris-EDTA buffer (10 mM Tris, 1 mM EDTA, pH 8.0), obtained with a laboratory blender. DNA was extracted from the samples with a robotic system (EpMotion 5070, Eppendorf, Hamburg, Germany), using DNA extraction kits for tissues or blood (Nucleospin, MachereyNagel, Germany). Quantification and purity of DNA samples was assessed with a spectrophotometer (Nanodrop 2000c, Thermo Scientific, Spain). E. nucleophila detection in these samples was carried out with specific primers for E. nucleophila SSU rRNA gene (Picard-Sánchez et al., 2020b), and the intensity of infection was determined using the reactions $\mathrm{Ct}$ values, with a positive cut-off value of $\mathrm{Ct}=38$. Standard curves with known numbers of the target gene were included in each plate and used as intra and inter-assay quality-controls. 


\subsubsection{Experimental transmission trials}

Four different experimental transmission trials were carried out, using donors from three different outbreaks at commercial sea cages, obtained in February 2013, March 2014 and April 2017 (Supplementary Table 1). The experiments within each trial focused on specific routes or conditions for the transmission and/or the downstream diagnostic tests applied. Details of these trials are summarised in Table 1.

Table 1. General information on the four different trials performed for Enterospora nucleophila horizontal transmission in gilthead sea bream.

\begin{tabular}{c|c|c|c|c|c} 
Trial & Challenge & $\begin{array}{c}\text { Mean water } \\
\text { temperature } \\
\left(\text { range) }\left({ }^{\circ} \mathrm{C}\right)\right.\end{array}$ & $\begin{array}{c}\text { Initial num- } \\
\text { ber of fish }\end{array}$ & $\begin{array}{c}\text { Samplings } \\
\text { (weeks post } \\
\text { exposure) }\end{array}$ & $\begin{array}{c}\text { Prevalence of } \\
\text { infection }(\%)^{2}\end{array}$ \\
\hline $\mathbf{1}$ & O-1 & $13.8(10.4-17.4)$ & 5R 6D & 12 & 20 \\
\hline & O-2 & $17.2(10.4-26.0)$ & 15R 10D & 8,20 & $14.3,0$ \\
\hline $\mathbf{2}$ & CH-1 & $16.9(10.4-25.0)$ & 15R 15D & 12,20 & $0,8.3$ \\
\hline & O-3 & $17.0(13.4-20.1)$ & 30R 15D & 4,8 & $70,55.2$ \\
\hline & EF-1 & $22.4(13.4-22.9)$ & 31R 31D & 4,10 & $66.7,87.1$ \\
\hline $\mathbf{3}$ & EF-2-LT & $16.0(15.5-16.5)$ & 20R 20C 20D & 4 & 50 \\
\hline 4 & EF-2-HT & $25.0(21.5-26.8)$ & 31R 20C 20D & 4,8 & $80.6,11.8$ \\
\hline O-4 & O-4-I & $19.8(15.0-25.6)$ & 30R 11C 22D & 4,12 & $0,5.5$ \\
\hline & A-1 & $16.2(15.0-25.6)$ & 40R 20C 22D 1 & 4,12 & 10,0 \\
\hline
\end{tabular}

Four different routes of infection were assayed: oral intubation $(\mathrm{O})$, cohabitation $(\mathrm{CH})$, effluent exposure (EF), and anal intubation (A). LT = low temperature; $\mathrm{HT}$ = high temperature; $\mathrm{I}=$ immunosuppressed fish. $\mathrm{D}=$ donor fish; $\mathrm{R}$ = recipient fish; $\mathrm{C}$ = control non-challenged fish. ${ }^{1}$ The inoculum for $\mathrm{O}-4$ and $\mathrm{O}-4-\mathrm{I}$ was prepared using the same 22 donor fish. ${ }^{2}$ The prevalence values correspond to the sampling times depicted in the previous column.

Transmission by water effluent exposure (EF) was performed by connecting tanks holding naïve recipient $(\mathrm{R})$ fish to receive the effluent water from another tank containing donor (D) fish, until the end of the experiment. The D tank was the only tank that received inlet water. Transmission by cohabitation $(\mathrm{CH})$ was performed holding in the same tank $\mathrm{R}$ and $\mathrm{D}$ fish tagged with passive integrated transponders (PIT-tags). Transmission by oral (O) or anal (A) intubation was made as described in Estensoro et al. (2010), with minor modifications. Briefly, intestinal scrapings of D fish were diluted with sterile Hank's balanced salt solution (HBSS), and intubated orally or anally to naïve $\mathrm{R}$ fish, using a blunt and narrow cannula. Water flow was adjusted to three renovations per day in all the trials. 
Trial 1. In this first small scale trial, two routes were assayed: oral (O-1, O-2) and cohabitation (CH-1) using $50 \mathrm{~g}$ fish (initial body weight) (Table 1). O-1 and O-2 experiments differed in the inoculum volumes used: $1 \mathrm{ml} /$ fish and $0.6 \mathrm{ml} /$ fish, respectively. Samplings were carried out at 8 and 20 weeks post challenge (wpc). In this trial, only histological diagnosis was performed.

Trial 2. Two routes were assayed: oral (O-3) and effluent (EF-1, EF-2-LT, EF-2-HT) using $40 \mathrm{~g}$ (O-3 and EF-1) and $80 \mathrm{~g}$ (EF-2-LT and EF-2-HT) fish (Table 1). The oral inoculum volume used was $1 \mathrm{ml} /$ fish. Samplings were carried out between 4 and 10 wpc. In 0-3 and EF-1, different diagnostic methods were used and compared: histology (CW staining, only in the first sampling) and molecular diagnosis. In the first sampling, molecular diagnosis was carried out by NL-qPCR from blood and rectal swabs. In the second sampling, L-qPCR was performed from blood and intestinal samples, either from separate intestinal segments (anterior, middle and posterior) and from the whole intestine homogenate to compare the results.

The effluent challenges EF-2-LT and EF-2-HT were setup to study differences due to water temperature (LT: low temperature, HT: high temperature). Here, the diagnosis was performed by NL-qPCR of rectal swabs in the first sampling, and by L-qPCR of whole intestine in the second sampling.

Trial 3. In this trial the oral route was tested in fish of $10 \mathrm{~g}$ of initial body weight. Here, a group of immunosuppressed fish (O-4-I) was included and compared to nonimmunosupressed fish (O-4) (Table 1). Immunosuppression of gilthead sea bream was induced with a synthetic corticosteroid, triamcinolone acetonide (TA) (Sigma) (Houghton \& Matthews, 1986). Briefly, $24 \mathrm{~h}$ before the challenge, O-4-I fish were intracoelomically injected with $100 \mu \mathrm{g} / \mathrm{g}$ body weight of TA suspension in $0.85 \%$ saline. Non-immunosuppressed fish received $0.85 \%$ saline. The oral inoculum volume was $0.25 \mathrm{ml} /$ fish $(26.3 \mu \mathrm{l} / \mathrm{g}$ of $\mathrm{R}$ fish body weight). Diagnosis was performed by NLqPCR of intestinal swabs at $4 \mathrm{wpc}$, and by L-qPCR of the whole intestine at 12 wpc.

Trial 4. In this trial, the anal intubation route was tested (A-1) (Table 1) using an inoculum volume of $1 \mathrm{ml} /$ fish in $30 \mathrm{~g}$ fish. Three sampling points were set at 4, 8, and 12 wpc. Diagnosis was performed by conventional histology and CW staining from the three different intestinal segments and by L-qPCR from the posterior intestine, aiming to compare the three diagnostic methods. In addition, L-qPCR with samples from other tissues (stomach, blood, heart, brain, spleen, gall bladder, head kidney, posterior kidney, liver, gills, and swim bladder) was also performed to have an overview of the systemic expansion of the parasite. 


\subsubsection{Statistics}

Statistical analyses were performed with GraphPad Prism 8 (GraphPad Software, Inc., San Diego, CA). Differences in prevalence of infection were calculated with Chi-squared test, and One-way ANOVA, or Student's t test for pairwise comparisons, were used to compare biometric parameters among the groups of each trial and sampling. In all cases, $p<0.05$ was considered statistically significant.

\subsection{RESULTS}

\subsubsection{Observations by trial}

\section{Trial 1}

Prevalence of infection in R fish (determined by histology) was $20 \%$ (1/5) in O-1 (high inoculum dose) at 12 wpc. In O-2 (low inoculum dose), prevalence was $14.3 \%$ $(2 / 7)$ at 8 wpc, but it dropped to $0 \%$ at 20 wpc. Most of the detected parasite stages were early merogonial stages, located in intranuclear position at the intestinal epithelium (Figures 1A, B). Immature spores were rarely found in the cytoplasm of infected cells and were released to the gut lumen in one specimen (Figure 1C). E. nucleophila in CH-1 was not detectable by histology until the last sampling (20 wpc) with a prevalence of $8.3 \%(1 / 12)$. 

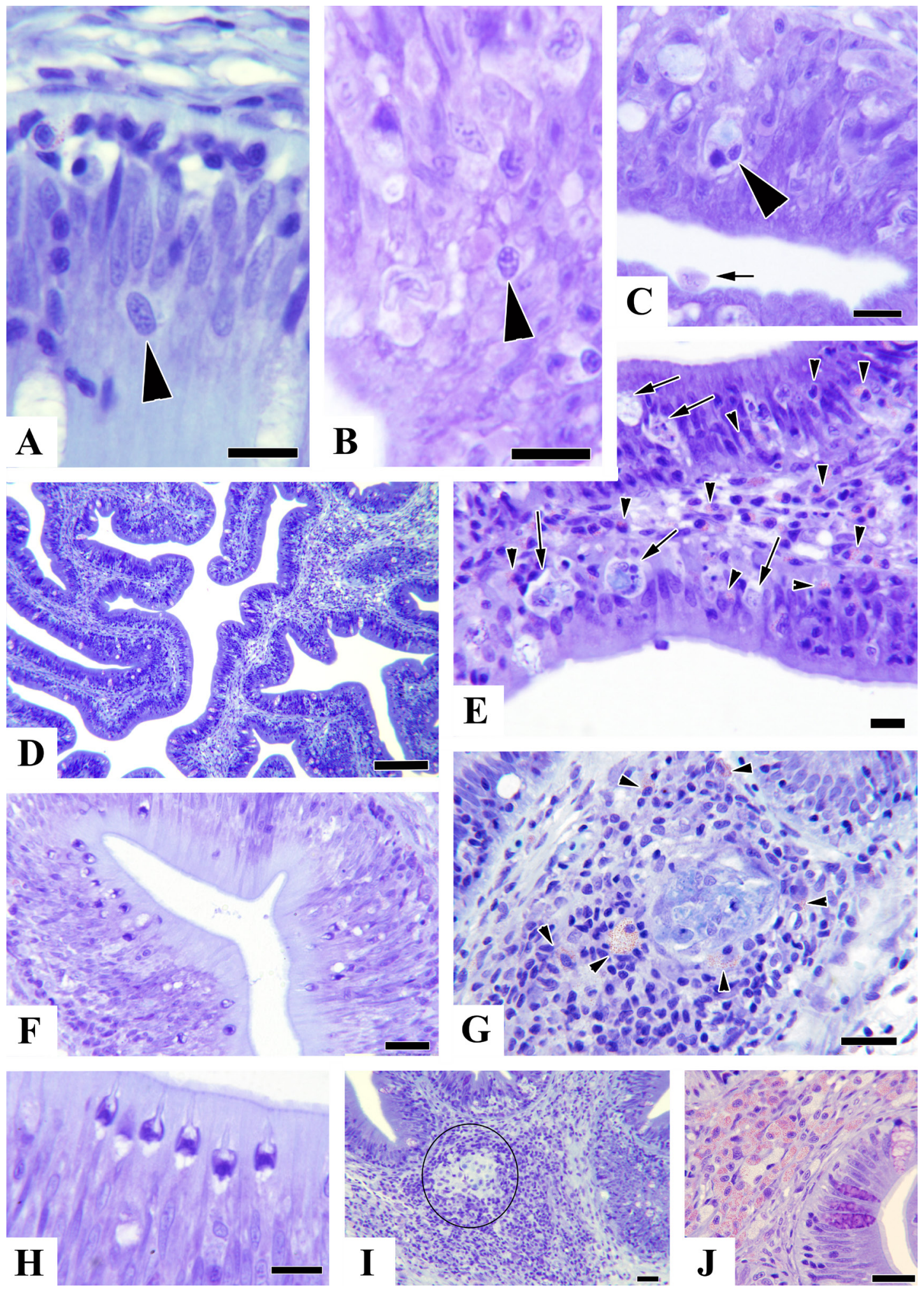

Figure 1. Photomicrographs from histological sections of resin-embedded gilthead sea bream intestines, experimentally exposed to Enterospora nucleophila in challenges O-2 (A, B, C, F, G) and CH-1 (D, E, H, I, J). Minute merogonial stages in the host cell nuclei (A, B) or cytoplasm (C) (arrowheads). Spores are visible within a cell in the lumen (arrow in C). Panoramic view showing conspicuous hypercellularity of the epithelium and submucosa (D). Vacuolisation (arrows), pyknotic nuclei, and infiltration of eosinophilic granular cells (arrow heads) (E). Proliferation of rodlet cells (F, H). Formation of macrophage aggregates (G, I) with lymphocytic infiltration (circle in I) and eosinophilic granular cells (arrowheads in G). Severe infiltration of eosinophilic granular cells in the submucosa (J). Anterior intestine (A, B, C, G, J); Middle intestine (D, E, I); Posterior intestine (F, H). Scale bars = $10 \mu \mathrm{m}$ (A, B, C, E, H), $20 \mu \mathrm{m}$ (F, G, I, J), $100 \mu \mathrm{m}$ (D). Staining = Giemsa. 


\section{Trial 2}

This trial had two objectives: to compare different diagnostic techniques in an oral (O-3) and an effluent (EF-1) transmission challenges, and to assess the effect of temperature in infection by effluent transmission (EF-2-LT and EF-2-HT). The results are summarized in Table 2 .

In O-3 and EF-1, histological diagnosis by CW white at 4 wpc was negative (not shown). However, NL-qPCR of intestinal swabs resulted in $70 \%$ and $66.7 \%$ of positive fish in 0-3 and EF-1, respectively. Molecular diagnosis in blood showed 93.3\% prevalence in EF-1 at 4 wpc, but in O-3 no infection was found in blood until the second sampling. Molecular diagnosis of different intestinal segments and whole intestine was performed in the second sampling. These results show that, as expected, qPCR of whole intestine always yields the highest prevalence values. Prevalence and intensity (median $\mathrm{Ct}$ ) values were always higher in EF-1 than in to O-3.

Effluent challenges EF-2 (EF-2-LT and EF-2-HT), explored two different water temperatures in parallel. All the fish in EF-2-LT died before termination of the experiment, probably due to the handling stress at lower temperature, and thus no data are available for the second sampling (8 wpc). Prevalence of infection by NL-qPCR reached 50\% in EF-2-LT and 80.6\% in EF-2-HT at 4 wpc, and showed a significant association with temperature (Chi-squared test, $p<0.05$ ). In the second sampling, the prevalence of EF-2-HT dropped to 11.7\%. Regarding clinical signs, differences in biometric parameters were detected only in EF-2-HT, which, in both sampling points showed significantly decreased size, length and condition factor when compared to the non-challenged control group. 
Table 2. Results of trial 2. Enterospora nucleophila horizontal transmission in gilthead sea bream was tested by oral intubation (O) and effluent exposure (EF). Fish were diagnosed by non-lethal (NL) or lethal (L) qPCR at two sampling times $(\mathrm{S} 1, \mathrm{~S} 2)$.

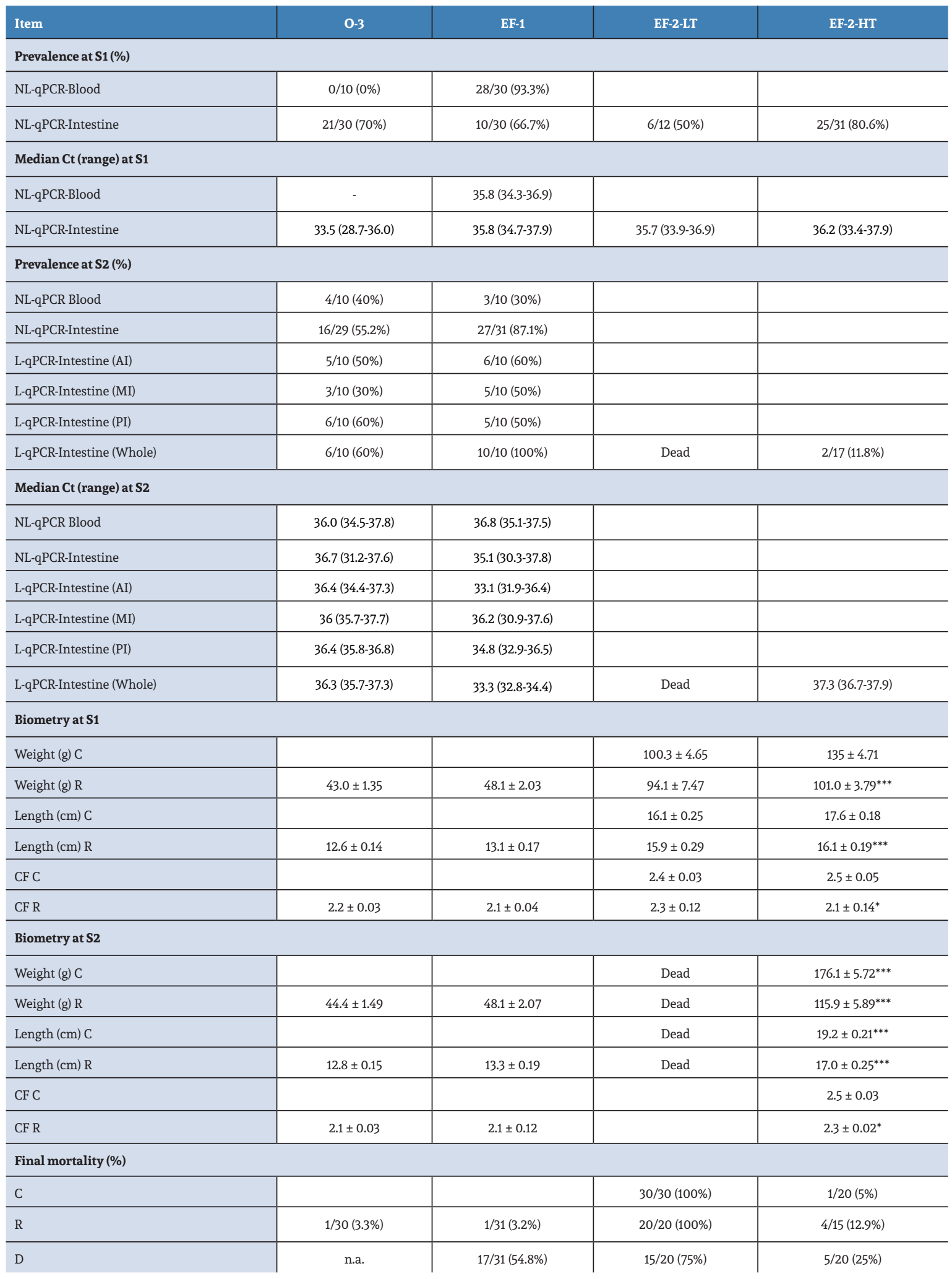

* LT = low temperature; $\mathrm{HT}$ = high temperature; $\mathrm{R}$ = recipient fish; $\mathrm{C}$ = control non-challenged fish; $\mathrm{D}=$ donor fish; $\mathrm{CF}=$ condition factor; n.a. = no available. Lethal qPCR in intestine was tested in anterior (AI), middle (MI) and posterior (PI) intestinal segments separately or in an homogenate of whole intestine. Asterisks indicate significant differences with the respective non-challenged control group: $p<0.05\left(^{*}\right)$ and $p<0.0001\left(^{* * *}\right)$. 


\section{Trial 3}

In this trial, we assayed the oral intubation route $(0-4)$ and the effect of immunosuppression (O-4-I) in an attempt to increase the susceptibility of the fish and achieve severe infections. The results of this trial are summarized in Table 3.

Table 3. Results of trial 3. Enterospora nucleophila horizontal transmission in gilthead sea bream by oral intubation of control (O-4) and immunosuppressed fish (O-4-I). Fish were diagnosed by non-lethal (NL) or lethal (L) qPCR at two sampling times (S1, S2).

\begin{tabular}{|c|c|c|}
\hline Item & $0-4$ & $0-4-I$ \\
\hline \multicolumn{3}{|l|}{ Prevalence at S1 (\%) } \\
\hline NL-qPCR-Intestine & $0 / 10(0 \%)$ & $1 / 10(10 \%)$ \\
\hline \multicolumn{3}{|l|}{ Median Ct (range) at S1 } \\
\hline NL-qPCR-Intestine & - & $34.5(34.5)$ \\
\hline \multicolumn{3}{|l|}{ Prevalence at S2 (\%) } \\
\hline L-qPCR-Intestine & $1 / 18(5.5 \%)$ & $0 / 2(0 \%)$ \\
\hline \multicolumn{3}{|l|}{ Median Ct (range) at S2 } \\
\hline L-qPCR-Intestine & $32.4(32.4)$ & - \\
\hline \multicolumn{3}{|l|}{ Biometry at to } \\
\hline Weight (g) C & $9.5 \pm 0.46$ & $9.5 \pm 0.35$ \\
\hline Weight (g) R & $10.1 \pm 0.34$ & $9.4 \pm 0.27$ \\
\hline Length $(\mathrm{cm}) \mathrm{C}$ & $7.7 \pm 0.10$ & $7.8 \pm 0.11$ \\
\hline Length $(\mathrm{cm}) \mathrm{R}$ & $8.2 \pm 0.17$ & $7.9 \pm 0.08$ \\
\hline $\mathrm{CF} C$ & $2.1 \pm 0.06$ & $2.0 \pm 0.04$ \\
\hline CF R & $2.1 \pm 0.06$ & $2.0 \pm 0.02$ \\
\hline \multicolumn{3}{|l|}{ Biometry at S1 } \\
\hline Weight $(\mathrm{g}) \mathrm{C}$ & n.a. & $11.0 \pm 0.65$ \\
\hline Weight (g) R & $10.5 \pm 0.38$ & $8.9 \pm 0.28^{*}$ \\
\hline Length $(\mathrm{cm}) \mathrm{C}$ & n.a. & $8.3 \pm 0.18$ \\
\hline Length $(\mathrm{cm}) \mathrm{R}$ & $8.1 \pm 0.09$ & $7.9 \pm 0.08^{*}$ \\
\hline $\mathrm{CFC}$ & n.a. & $1.9 \pm 0.06$ \\
\hline CF R & $2.0 \pm 0.05$ & $1.8 \pm 0.03$ \\
\hline \multicolumn{3}{|l|}{ Biometry at S2 } \\
\hline Weight (g) C & $46.6 \pm 2.45$ & $33.6 \pm 1.53$ \\
\hline Weight (g) R & $26.0 \pm 1.60^{* * *}$ & $10.3 \pm 1.02^{* * *}$ \\
\hline Length $(\mathrm{cm}) \mathrm{C}$ & $12.5 \pm 0.15$ & $11.5 \pm 0.16$ \\
\hline Length $(\mathrm{cm}) \mathrm{R}$ & $10.8 \pm 0.23^{* * *}$ & $8.4 \pm 0.10^{* * *}$ \\
\hline $\mathrm{CF} \mathrm{C}$ & $2.4 \pm 0.06$ & $2.2 \pm 0.04$ \\
\hline CF R & $2.0 \pm 0.03^{* * *}$ & $1.7 \pm 0.11^{* * *}$ \\
\hline \multicolumn{3}{|l|}{ Mortality (\%) } \\
\hline $\mathrm{C}$ & $1 / 11(9.1 \%)$ & $4 / 20(20 \%)$ \\
\hline $\mathrm{R}$ & $12 / 30(40 \%)$ & $34 / 40(85 \%)$ \\
\hline
\end{tabular}

$\mathrm{R}=$ recipient fish; $\mathrm{C}$ = control non-challenged fish; $\mathrm{n} . \mathrm{a} .=$ no available. Asterisks indicate significant differences with the respective non-challenged control groups: $p<0.05\left(^{*}\right)$ and $p<0.0001\left(^{* * *}\right)$. 
Few animals were found infected by L-qPCR of intestinal samples. Prevalence of infection in the immunosuppressed group was $10 \%$ at $4 \mathrm{wpc}$ and $0 \%$, at 8 wpc. In the non-immunosuppressed group, prevalence was $0 \%$ and 5.5\%, at 4 and 8 wpc, respectively. Biometric values (weight, length and $\mathrm{CF}$ ) were significantly lower in both R groups, particularly at $8 \mathrm{wpc}$, when compared to the control non-challenged groups.

Considerable mortality was recorded during this trial, reaching $85 \%$ and $40 \%$ in $\mathrm{R}$ immunosuppressed (O-4-I) and untreated (O-4) groups, respectively. Unfortunately, samples from carcasses could not be recovered for qPCR testing and the infectious status of the dead fish was unknown. This notwithstanding, the mortality registered in non-challenged groups was $20 \%$ in the immunosuppressed control group and 9.1\% in the untreated control group. In R fish, mortality and immunosuppression were significantly associated (Chi-squared test, $p<0.0001)$. This association was not found in the non-challenged groups (Chi-squared test, $p>0.05$ ).

\section{Trial 4}

In this trial, the anal intubation route was explored, and the infectious status was monitored by qPCR in different organs, in monthly intervals along a 3-month period after the challenge. A comparison between histological and molecular diagnosis was also performed in intestinal samples. The results of the parasitological diagnosis are summarised in Table 4 and Figure 2. No statistically significant differences between challenged and non-challenged control groups were detected for biometrical parameters at any sampling point. No mortality was registered.

The tissues with higher prevalence of infection by L-qPCR were the stomach and the intestine, reaching $80-100 \%$. The prevalence of infection increased in the intestine and was maintained high with time, whereas in the stomach the prevalence was higher in the first sampling, dropping to $20 \%$ in the last sampling. In lymphohematopoietic organs, the highest prevalence of infection was $20-30 \%$ in spleen and kidney, respectively, at 4 wpc, but these values dropped to $10 \%$ subsequently in both tissues. Gills and liver also reached high values (up to 80\%) at certain samplings, but a gradual increase or decrease with time was not detected. Regarding the intensity of infection, the lowest Ct values (highest intensity of infection) were consistently observed in the intestine (Table 4). 


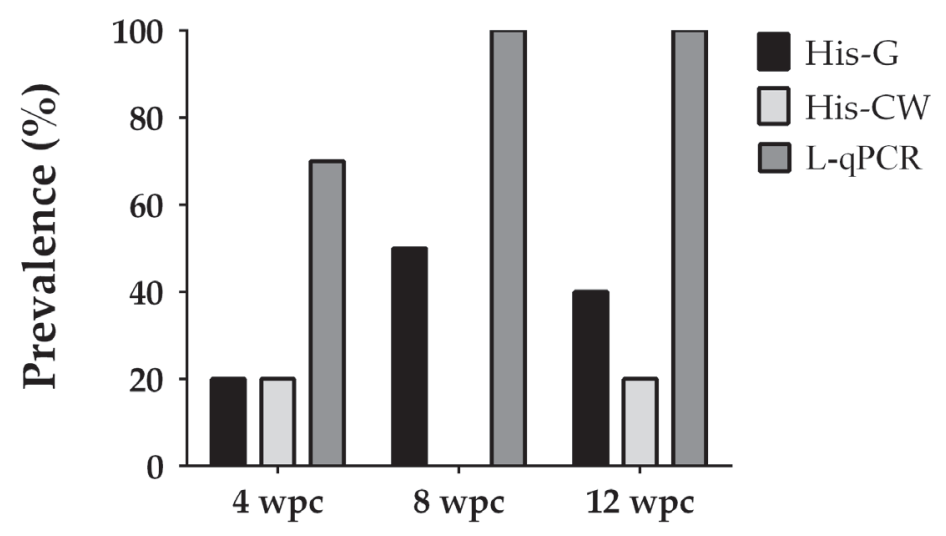

Figure 2. Prevalence of infection of gilthead sea bream experimentally challenged with Enterospora nucleophila by anal intubation (A-1, Trial 4) and sampled at different weeks post challenge (wpc). Parasite detection in the intestine was done from lethal samples by histology with Giemsa (His-G), calcofluor-white (His-CW) staining, and molecular diagnosis (L-qPCR). Fish with Ct values below 38 were considered qPCR positive.

Detection of the parasite by histology was less sensitive than the qPCR (Figure 2). In the intestine, spores were detected in CW-paraffin sections in $20 \%$ of the samples at 4 and $12 \mathrm{wpc}$, but all samples were negative in the intermediate sampling. In Giemsa-stained sections, merogonial and sporogonial stages of E. nucleophila were found with a prevalence of $20 \%, 50 \%$ and $40 \%$ at 4 , 8 , and 12 wpc, respectively. In most cases, parasite stages were scarce. Most fish, although with no detectable E. nucleophila stages, displayed common histopathological conditions in variable degrees: cells with cytoplasmic debris, abnormalities in the nucleus of intestinal epithelial cells, hypercellularity in epithelium or submucosa layer, vacuolated cells and increased number of eosinophils.

For a quick comparison of all trials and challenge routes, a summary of the prevalence of infection is presented in the last column of Table 1. A common pattern found in most of the exposed fish $(\mathrm{R})$ was a higher prevalence of infection at shorter times post-challenge than at longer exposure times. However, in EF-1 and A-1, prevalence increased over time. 
Table 4. Infection values of Enterospora nucleophila in experimentally challenged gilthead sea bream by anal intubation (A-1, Trial 4). Fish were diagnosed by lethal qPCR at different weeks post challenge (wpc) (qPCR positive cut-off was $\mathrm{Ct}<38$ ); n.a. = no available.

\begin{tabular}{|c|c|c|c|c|c|c|}
\hline \multicolumn{7}{|c|}{ (Sampling time) } \\
\hline & \multicolumn{2}{|c|}{4 wpc } & \multicolumn{2}{|c|}{8 wpc } & \multicolumn{2}{|c|}{12 wpc } \\
\hline Tissue & $\begin{array}{l}\text { Ct median } \\
\text { (range) }\end{array}$ & $\begin{array}{c}\text { Prevalence } \\
\text { (\%) }\end{array}$ & $\begin{array}{c}\text { Ct median } \\
\text { (range) }\end{array}$ & $\begin{array}{l}\text { Prevalence } \\
\text { (\%) }\end{array}$ & $\begin{array}{l}\text { Ct median } \\
\text { (range) }\end{array}$ & $\begin{array}{c}\text { Prevalence } \\
\text { (\%) }\end{array}$ \\
\hline \multirow[t]{2}{*}{ Blood } & \multirow[t]{2}{*}{-} & $0 / 10$ & 37.2 & $1 / 10$ & 37.0 & $3 / 10$ \\
\hline & & $(0 \%)$ & $(37.2)$ & $(10 \%)$ & $(36.0-37.0)$ & $(30 \%)$ \\
\hline \multirow[t]{2}{*}{ Brain } & 36.7 & $1 / 10$ & \multirow{2}{*}{ 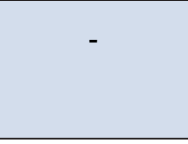 } & $0 / 10$ & \multirow[t]{2}{*}{-} & $0 / 10$ \\
\hline & $(36.7)$ & $(10 \%)$ & & $(0 \%)$ & & $(0 \%)$ \\
\hline \multirow[t]{2}{*}{ Gallbladder } & \multirow[t]{2}{*}{-} & $0 / 10$ & 36.0 & $1 / 10$ & 37.2 & $2 / 10$ \\
\hline & & $(0 \%)$ & $(36.0)$ & $(10 \%)$ & $(36.5-37.6)$ & $(20 \%)$ \\
\hline \multirow[t]{2}{*}{ Gills } & 36.2 & $8 / 10$ & 36.3 & $1 / 10$ & 37.5 & $4 / 10$ \\
\hline & $(35.4-37.8)$ & $(80 \%)$ & $(36.3)$ & $(10 \%)$ & $(36.5-37.8)$ & $(40 \%)$ \\
\hline \multirow[t]{2}{*}{ Heart } & 34.3 & $5 / 10$ & 37.0 & $4 / 10$ & 37.3 & $3 / 10$ \\
\hline & $(33.3-37.3)$ & $(50 \%)$ & $(36.1-37.8)$ & $(40 \%)$ & $(36.0-37.7)$ & (30\%) \\
\hline Head & 37.3 & $3 / 10$ & 37.1 & $1 / 10$ & 37.6 & $1 / 10$ \\
\hline kidney & $(36.6-37.9)$ & (30\%) & (37.1) & $(10 \%)$ & (37.6) & $(10 \%)$ \\
\hline \multirow[t]{2}{*}{ Intestine } & 32.0 & $7 / 10$ & 33.5 & $10 / 10$ & 30.9 & $10 / 10$ \\
\hline & $(27.5-37.2)$ & $(70 \%)$ & $(26.3-35.7)$ & $(100 \%)$ & $(26.1-37.6)$ & $(100 \%)$ \\
\hline \multirow[t]{2}{*}{ Liver } & 33.4 & $7 / 10$ & 37.0 & $8 / 10$ & 35.4 & $2 / 10$ \\
\hline & $(31.8-37.6)$ & $(70 \%)$ & $(35.7-37.5)$ & $(80 \%)$ & $(33.0-37.7)$ & $(20 \%)$ \\
\hline \multirow{2}{*}{$\begin{array}{l}\text { Posterior } \\
\text { kidney }\end{array}$} & - & $0 / 10$ & 37.5 & $1 / 10$ & 36.0 & $2 / 10$ \\
\hline & & $(0 \%)$ & $(37.5)$ & $(10 \%)$ & $(35.0-37.0)$ & $(20 \%)$ \\
\hline \multirow[t]{2}{*}{ Spleen } & 34.6 & $2 / 10$ & 37.0 & $2 / 10$ & 36.0 & $1 / 10$ \\
\hline & $(33.1-35.5)$ & $(20 \%)$ & $(36.7-37.3)$ & $(20 \%)$ & (36.0) & $(10 \%)$ \\
\hline \multirow[t]{2}{*}{ Stomach } & 34.2 & $8 / 10$ & 34.4 & $6 / 10$ & 36.4 & $2 / 10$ \\
\hline & $(26.2-37.9)$ & $(80 \%)$ & $(31.7-37.4)$ & $(60 \%)$ & $(35.5-37.3)$ & $(20 \%)$ \\
\hline Swim & n.a. & n.a. & 35.7 & $4 / 10$ & 37.5 & $3 / 10$ \\
\hline bladder & & & $(34.8-37.9)$ & $(40 \%)$ & $(36.5-37.6)$ & $(30 \%)$ \\
\hline
\end{tabular}




\subsubsection{Common histopathological observations among trials}

Common histopathological features were observed in $\mathrm{R}$ fish with no detectable E. nucleophila parasitic stages from trials 1 and 4:1) conspicuous hypercellularity in the intestinal epithelial layer (Figure 1D) with disorganization of the palisade structure, in which enterocyte nuclei presented anomalous chromatin patterns; 2) presence of epithelial vacuolated cells with debris (Figure 1E); 3) proliferation of rodlet cells in the epithelium (Figure 1F, H); 4) hyperplasia of the submucosal with lymphocytic infiltration, sometimes surrounding early melanomacrophage centers (MMC) (Figure 1G, I); and 5) proliferation of eosinophilic granular cells in the submucosa with certain infiltration in the mucosa (Figure 1)).

\subsubsection{Additional observations in donor fish}

During the different trials, the lots of fish used as donors (D) were periodically sampled, and their infection status evaluated by histology and/or qPCR. Results of those samplings are summarised in Supplementary Table1. In general, a progressive loss of infection was registered throughout time in these lots, and variations in the diagnostic sensitivity among techniques were observed. Molecular detection was the most sensitive technique, followed by the examination of Giemsa-stained resin slides, and examination of CW-stained slides. However, differences in the clearing of the infection with time were observed depending on the D lot. All the $\mathrm{D}$ fish from lot 1 remained positive by qPCR even after 386 days, whereas, in the remaining trials, prevalence of $D$ fish dropped from $100 \%$ to values as low as $6.7 \%$ at subsequent samplings.

\section{DISCUSSION}

Microsporidian parasites are spore-forming obligate parasites, widespread in the animal kingdom, that mainly infect arthropods and fish (Mc Connaughey, 2014). Their importance in cultured fish has increased in parallel with the worldwide growth of aquaculture production (Kent et al., 2014). In cultured gilthead sea bream, several microsporidian infections have been described (Abela et al., 1996; Athanassopoulou, 1998; Morsy et al., 2013), being E. nucleophila the most recent and an emerging problem in the industry (Palenzuela et al., 2014). Information about natural E. nucleophila transmission was scarce when the current trials started, however, there was a clear indication of the existence of long pre-patent period (several months) in which fish harbouring the parasite do not show any disease signs. Indeed, farmed fish with asymptomatic infection diagnosed by qPCR, showed the typical infection signs (pale organs, arrested growth, cachexia) and severe histopathological damage three months later (Picard-Sánchez et al., 2020b). 
In this work, we succeeded in transmitting the parasite by oral, effluent, cohabitation and anal challenge, as the parasite could be detected in R fish by NLand L-qPCR of intestine, though, in many cases, it was not detected by conventional histopathological examination. We did not test intracoelomic and intramuscular injections, despite being successful in other fish models (Matthew \& Matthew, 1980; Shaw et al., 1998). The prevalence of infection achieved varied highly depending on the transmission method and the infection status of donor (D) fish. As a general trend, higher prevalence was obtained at short times by oral and anal intubation routes, and longer times were needed to detect the parasite with the effluent route. Differences in the transmission rate between anal and oral routes may be due to the direct inoculation into the target organ. Indeed, anal intubation already has been described as the quickest route of transmission for another enteric parasite of gilthead sea bream, Enteromyxum leei (Estensoro et al., 2010). In most trials, a decreasing trend of detectable parasite levels was observed, which paralleled the findings observed in most donors at longer times (Supplementary Table 1), as well as the long-term epidemiological studies performed by the authors in fish farms (unpublished data). This could be explained in part by the temperature increase along the trials, which would allow the fish to activate a successful immune response and clear off the parasite. Signs of infection and prevalence in the field tend to disappear between April-November, while the current challenges ended in late spring or summer (see temperature ranges in Table 1). In fact, the common observations in $\mathrm{R}$ fish of intestinal epithelial cells with debris, hyperplasic submucosa with leucocyte infiltration, and the development of macrophage aggregates in the submucosa, could be interpreted as signs of a strong host reaction in agreement with this hypothesis. The fact that fish with no apparent clinical signs (both $\mathrm{D}$ and $\mathrm{R}$ ) have detectable levels of the parasite by qPCR for long periods has epidemiological implications in aquaculture, as they may behave as asymptomatic carriers of the parasite. Specific studies using ISH methods for E. nucleophila have also suggested the risk of incomplete infection clearing and reactivation of covert infections with this parasite (Ahmed et al., 2019).

In nature, microsporidian infections may range from asymptomatic to severe, even resulting in death (Baker, 1987; Kent et al., 2014; Lee et al., 2004). However, these parasites are generally considered as having a relatively balanced relationship with their hosts, normally causing chronic subclinical infections, but presenting large oportunistic potential (Stentiford et al., 2016; Vávra \& Luckeš, 2013). Indeed, immunodeficient mammals are classic examples in which microsporidian infections can result in serious clinical diseases. This highlights the important role of immune competence in alleviating health effects of microsporidiosis at individual- and population-level (Khan \& Didier, 2008). Outbreaks by E. nucleophila in gilthead sea bream farms coincide, in most cases, with winter temperatures, when the performance of the fish immune system is lowered (Abram et al., 2017). Immune status of fish is highly affected also by cortisol 
levels, which can be naturally raised by handling, overcrowding, water temperature changes, etc., or induced by injection of analogues such as triamcinolone acetonide (TA). In this study, we tested a natural immunosuppressor (low water temperature) (trial 2), and an artificial one (trial 3). The outcome of using an immunosuppressor resulted in higher prevalence of E. nucleophila at short-time sampling points (trial 3), although low overall prevalence of infection was achieved in this trial, probably due to the use of D fish with long-lasting infections in recovery stages. Further experiments using overtly infected $\mathrm{D}$ fish would probably improve the results. Other studies have described the rise in pathogenicity for fish microsporidians after triggering events. For example, in P. neurophilia zebrafish infections, clinical signs and mortality usually become apparent after stressful operations like crowding or shipping (Ramsay et al., 2009), or after experimental immunosuppression by irradiation (Spagnoli et al., 2016). A different study revealed that intensity of infection by Loma salmonae can increase after a dexamethasone treatment in rainbow trout (Lovy et al., 2008). In our case, no differences were observed when comparing high and low temperatures (LT) for parasite transmission (EF-2, trial 2), although high mortality was registered in the LT group. Therefore, further studies are needed using water temperature lower than $16^{\circ} \mathrm{C}$, typical of winter months, and for a longer period. Generally, low water temperatures are described to inhibit microsporidian development in fish (Kent et al., 2014), but in warmer latitudes the parasites must reach a compromise between the immunological status of the host and optimal parasite reproductive temperature. This is the case of Pleistophora aegyptiaca, which infects greater lizardfish (Saurida tumbil) in the Red Sea (Abdel-Ghaffar et al., 2012), reaching seasonal infection peaks in winter. In line with this hypothesis, we have recently described that the adaptive immune response of gilthead sea bream decreases with temperature (Picard-Sánchez et al., 2020a).

Along the different trials, different diagnostic methods were used and it turned out, as expected, that qPCR was the most sensitive. As an example, in trial 1, prevalence determined by histology, was about $1 / 3$ of the value obtained by qPCR in similar subsequent challenges (trial 2). When parallel samples were analysed by histology and qPCR from R fish (Figure 2) or from D fish (Supplementary table 1), the prevalence values were always lower for histological methods. Indeed, when histopathological examination of $\mathrm{R}$ fish from other trials was conducted, most samples did not show parasite stages, but only the histopathological alterations typical of the infection. Only in the anal challenge (trial 4), when prevalence by qPCR reached $100 \%$, unambiguous merogonial stages were detectable in the intestine of $40 \%$ of $\mathrm{R}$ fish and spores in $20 \%$ at $12 \mathrm{wpc}$.

Considering the results obtained by qPCR in blood samples, it is tempting to suggest that blood could represent a systemic dispersion route within the host. In fact, in EF-1, the parasite was detected in blood with very high prevalence $(93.3 \%)$ as early as $4 \mathrm{wpc}$, which decreased considerably at $10 \mathrm{wpc}$. Similar prevalence values were 
found at 8 wpc in blood during 0-3 challenge and the lowest prevalence detected in blood was in the anal challenge (20\% at $8 \mathrm{wpc}$ ). These observations are consistent with the detection of $E$. nucleophila spores in peripheral blood reported in a previous study (Ahmed et al., 2019). Systemic transportation of parasites via peripheral blood has also been reported in other fish microsporidians. Studies on xenomaforming microsporidians such as Glugea spp. and Loma spp. have shown that host cells within the blood lineage (e.g., macrophages) provide the transportation to the gills, where the final development occurs (Sánchez et al., 2001). In E. nucleophila infections, macrophages are indeed commonly infected, mainly present in the intestinal submucosa but also in blood vessels (Palenzuela et al., 2014; PicardSánchez et al., 2020b). These cells are involved in the parasite clearing mechanisms through the development of MMC in the intestine submucosae, where parasite debris accumulates in advanced infections (Ahmed et al., 2019). However, they may also play a role in the dispersion and reinfection within the host. Other blood cells, such as erythrocytes, which often exhibit anomalous chromatin patterns in infected fish, could also participate in this systemic dispersal.

The disease signs of this microsporidiosis in naturally infected fish consist of arrested growth, poor condition and emaciative syndrome during farm outbreaks, in association with dropping mortalities. These signs were clearly observed in donor fish brought to our facilities, reaching mortalities higher than $50 \%$ in most cases and showing severe growth arrestment. Interestingly, a decrease in condition factor (CF) was also observed in trials 2 and 3, as soon as $4 \mathrm{wpc}$ and in coincidence with a high prevalence of infection in R fish in the EF-2 challenge. This arrested growth still persisted one month later at the next sampling, despite the much lower infection levels found. In both O-4-I and O-4-N challenges of trial 3, although very low infection levels were reached in $\mathrm{R}$ fish, $\mathrm{CF}$ was also significantly lower than in control fish. Further studies are needed to understand the mechanisms involved in this growth arrestment and to reproduce them in the same degree as observed in natural infections. Regarding the histological examination, though many challenged $\mathrm{R}$ fish did not present detectable merogonial or sporogonial stages at certain samplings, a common histopathological pattern was repeatedly observed in most. It consisted in hypercellularity in epithelium and submucosae, epithelial cells vacuolated and presence of debris, enterocytes with abnormal nuclei, proliferation and infiltration of granulocytes, and proliferation of rodlet cells in the epithelium. These signs have previously been interpreted as initial signs of E. nucleophila infection (Palenzuela et al., 2014; Picard-Sánchez et al., $2020 \mathrm{~b}$ ), and specific ISH studies have shown that they are often associated to high parasite load and merogonial activity (Ahmed et al., 2019). Therefore, considering that histology is less sensitive than molecular diagnosis to detect the parasitic stages, this histopathological pattern might be used as an indicator of presumptive infection, to obtain further samples for confirmation by molecular methods. 
In view of all these results, we can conclude that E. nucleophila was successfully transmitted by all the tested infection routes. The anal intubation route seems to be the most successful method, since prevalence reached the maximum value and the infection prevailed at high levels for longer than in other challenges using different routes (oral, effluent and cohabitation). However, the clinical disease signs were not reproduced in the same degree as in naturally infected fish. Certain initial signs of infection were observed, since some R groups showed a significant delay in growth, but these effects were not observed consistently in the follow-up period of all the trials. The results indicate that water temperature, time of exposure, the infective status of $\mathrm{D}$ fish and the immunocompetence of $\mathrm{R}$ fish are relevant, possibly more than the challenge route per se. Thus, future studies should aim to longer exposure times at lower temperatures, and using overtly infected D fish.

\section{ACKNOWLEDGMENTS \& FUNDING}

The authors kindly acknowledge the collaboration of J. Monfort and L. Rodríguez for the technical assistance on histological processing. We thank the anonymous fish farming companies allowing access to the animals during the disease outbreaks.

This work has been carried out with financial support from the European Union and the Spanish MINECO under grant projects ParaFishControl (H2020634429) and AGL2013-R-48560-C2-2-R, respectively. A.P-S was contracted under ParaFishControl project. This publication reflects only the authors' view, and the European Commission cannot be held responsible for any use which may be made of the information contained herein. M.C.P. was funded by a Ramón y Cajal Postdoctoral Research Fellowship (RYC2018-024049-I/AEI/10.13039/501100011033 \& ACOND/2020 Generalitat Valenciana), and R.P. was contracted under the PTAProgram from the Spanish Ministry of Science, Innovation and Universities (PTA2018-015315-I). Both contracts have been co-funded by the European Social Fund (ESF). 


\section{Bibliography}


Abdel-Ghaffar F., Bashtar A. R., Morsy K., Mehlhorn H., Al-Quraishy S., Al-Rasheid, K., Abdel-Gaber R. (2012) Morphological and molecular biological characterization of Pleistophora aegyptiaca sp. nov. infecting the Red Sea fish Saurida tumbil. Parasitol Res. 110:741-752.

Abela M., Brinch-Iversen J., Tanti J., Le Breton A. (1996) Occurrence of a new histozoic microsporidian (Protozoa, Microspora) in cultured gilt head sea bream Sparus aurata L. Bull Eur Assoc Fish Pathol. 16:196-199.

Abram Q. H., Dixon B., Katzenback B. A. (2017) Impacts of low temperature on the teleost immune system. Biology. 6:39.

Ahmed N. H., Caffara M., Sitjà-Bobadilla A., Fioravanti M. L., Mazzone A., Aboulezz A. S., Metwally A. M., Omar M. A. E., Palenzuela O. R. (2019) Detection of the intranuclear microsporidian Enterospora nucleophila in gilthead sea bream by in situ hybridization. J Fish Dis. 42:809-815.

Athanassopoulou F. (1998) A case report of Pleistophora sp. infection in cultured sea bream (Sparus aurata L.) in Greece. Bull Eur Assoc Fish Pathol. 18:9-21.

Baker J. (1987) The Microsporidia of Vertebrates, in: Elizabeth U., Canning E. U., Lom J. (Eds.) Parasitology. Academic Press, London, UK. Vol. 94, pp. 597-599.

Baxa D., Groff J., Hedrick R. (1992) Experimental horizontal transmission of Enterocytozoon salmonis to chinook salmon, Oncorhynchus tshawytscha. J Protozool. 39:699-702.

Becnel J. J. (1992) Horizontal transmission and subsequent development of Amblyospora californica (Microsporidia: Amblyosporidae) in the intermediate and definitive hosts. Dis Aquat Organ. 13:17-28.

Dunn A., Smith J. (2001) Microsporidian life cycles and diversity: The relationship between virulence and transmission. Microb Infect. 3:381-388.

Estensoro I., Redondo M. J., Álvarez-Pellitero P., Sitjà-Bobadilla A. (2010) Novel horizontal transmission route for Enteromyxum leei (Myxozoa) by anal intubation of gilthead sea bream Sparus aurata. Dis Aquat Organ. 92:51-58.

Houghton G., Matthews R. A. (1986) Immunosuppression of carp (Cyprinus carpio L.) to ichthyophthiriasis using the corticosteroid triamcinolone acetonide. Vet Immunol Immunopathol. 12:413-419.

Kent M. L., Shaw R. W., Sanders J. L. (2014) Microsporidia in Fish, in: Weiss L. M., Becnel J. J. (Eds.) Microsporidia. pp. 493-520.

Kent M., Bishop-Stewart J. (2003) Transmission and tissue distribution of Pseudoloma neurophilia (Microsporidia) of zebrafish, Danio rerio (Hamilton). J Fish Dis. 26:423-426.

Khan I., Didier E. (2008) Insights into the immune responses to Microsporidia, in: Weiss L. M., Lindsay D. S. (Eds.) Opportunistic Infections: Toxoplasma, Sarcocystis, and Microsporidia. Springer, Boston, Massachusetts, USA. Vol. 9. pp. 135-158.

Lee S. J., Yokoyama H., Ogawa K. (2004) Modes of transmission of Glugea plecoglossi (Microspora) via the skin and digestive tract in an experimental infection model using rainbow trout, Oncorhynchus mykiss (Walbaum). J Fish Dis. 27:435-444.

Leiro J. M., Piazzon C., Domínguez B., Mallo N., Lamas J. (2012) Evaluation of some physical and chemical treatments for inactivating microsporidian spores isolated from fish. Int J Food Microbiol. 156:152-160.

Li X., Fayer R. (2006) Infectivity of microsporidian spores exposed to temperature extremes and chemical disinfectants. J Eukaryot Microbiol. 53:77-79.

Lom J., Dyková I. (1992) Microsporidia (Phylum Microspora Sprague, 1977), in: Lom J., Dyková I. (Eds.) Protozoan Parasites of Fishes Developments in Aquaculture and Fisheries Science. Elsevier Science, Amsterdam, Netherlands. Vol. 26. pp. 125-157.

Lovy J., Speare D. J., Stryhn H., Wright G. M. (2008) Effects of dexamethasone on host innate and adaptive immune responses and parasite development in rainbow trout Oncorhynchus mykiss infected with Loma salmonae. Fish Shellfish Immunol. 24:649-658.

Matthews R. A., Matthews B. F. (1980) Cell and tissue reactions of turbot Scophthalmus maximus (L.) to Tetramicra 
brevifilum gen. n., sp. n. (Microspora). J Fish Dis. 3:495-515.

Mc Connaughey, M. B. (2014) Physical Chemical Properties of Fungi, in: XPharm: The Comprehensive Pharmacology. Elservier Inc., Greenville, North Carolina, USA. pp. 1-3.

Mc Vicar A. H. (1975) Infection of plaice Pleuronectes platessa L. with Glugea (Nosema) stephani (Hagenmüller 1899) (Protozoa: Microsporidia) in a fish farm and under experimental conditions. J Fish Biol. 7:611-619.

Micieli M. V, García J. J., Becnel J. J. (2000) Horizontal transmission of Amblyospora albifasciati García and Becnel, 1994 (Microsporidia: Amblyosporidae), to a copepod intermediate host and the neotropical mosquito, Aedes albifasciatus (Macquart, 1837). J Invertebr Pathol. 75:76-83.

Morsy K., Bashtar A. R., Abdel-Ghaffar F., Al-Quraishy S. (2013) Morphological and phylogenetic description of a new xenoma-inducing microsporidian, Microsporidium aurata nov. sp., parasite of the gilthead seabream Sparus aurata from the Red Sea. Parasitol Res. 112:3905-3915.

Olson R. E. (1976) Laboratory and field studies on Glugea stephani (Hagenmuller), a microsporidan parasite of pleuronectid flatfishes. J Protozool. 23:158-164.

Palenzuela O., Redondo M. J., Cali A., Takvorian P. M., Alonso-Naveiro M., Álvarez-Pellitero P., Sitjà-Bobadilla A. (2014) A new intranuclear microsporidium, Enterospora nucleophila n. sp., causing an emaciative syndrome in a piscine host (Sparus aurata), prompts the redescription of the family Enterocytozoonidae. Int J Parasitol. 44:189203.

Picard-Sánchez A., Estensoro I., del Pozo R., Palenzuela O., Piazzon M. C., Sitjà-Bobadilla A. (2020a) Water temperature, time of exposure and population density are key parameters in Enteromyxum leei fish-to-fish experimental transmission. J Fish Dis. 43:491-502.

Picard-Sánchez A., Piazzon M. C., Ahmed N. H., del Pozo R., Sitjà-Bobadilla A., Palenzuela O. (2020b) Enterospora nucleophila (Microsporidia) in gilthead sea bream (Sparus aurata): Pathological effects and cellular immune response in natural infections. Vet Pathol. 57:565-576.

Ramsay J. M., Speare D. J., Daley J. (2004) Timing of changes in growth rate, feed intake and feed conversion in rainbow trout, Oncorhynchus mykiss (Walbaum), experimentally infected with Loma salmonae (Microspora). J Fish Dis. 27:425-429.

Ramsay J. M., Watral V., Schreck C. B., Kent M. L. (2009) Pseudoloma neurophilia infections in zebrafish Danio rerio: effects of stress on survival, growth, and reproduction. Dis Aquat Organ. 88:69-84.

Sánchez J., Speare D., Markham R., Wright G., Kibenge F. (2001) Localization of the initial developmental stages of Loma salmonae in rainbow trout (Oncorhynchus mykiss). Vet Pathol. 38:540-546.

Sanders J. L., Lawrence C., Nichols D. K., Brubaker J. F., Peterson T. S., Murray K. N., Kent M. L. (2010) Pleistophora hyphessobryconis (Microsporidia) infecting zebrafish Danio rerio in research facilities. Dis Aquat Organ. 91:47-56.

Sanders J., Peterson T., Kent M. L. (2014) Early development and tissue distribution of Pseudoloma neurophilia in the zebrafish, Danio rerio. J Eukaryot Microbiol. 61:238-246.

Shaw R., Kent M. L., Adamson M. (2001) Viability of Loma salmonae (Microspora) under laboratory conditions. Parasitol Res. 86:978-981.

Shaw R., Kent M. L., Adamson M. (1998) Modes of transmission of Loma salmonae (Microsporidia). Dis Aquat Organ. 33:151-156.

Spagnoli S. T., Sanders J. L., Watral V., Kent M. L. (2016) Pseudoloma neurophilia infection combined with gamma irradiation causes increased mortality in adult zebrafish (Danio rerio) compared to infection or irradiation alone: New implications for studies involving immunosuppression. Zebrafish. 13:107-114.

Stentiford G. D., Becnel J. J., Weiss L. M., Keeling P. J., Didier E. S., Williams B. A. P., Bjornson S., Kent M. L., Freeman M. A., Brown M. J. F., Troemel E. R., Roesel K., Sokolova Y., Snowden K. F., Solter, L. F. (2016) MicrosporidiaEmergent pathogens in the global food chain. Trends Parasitol. 32:657.

Szumowski S. C., Troemel E. R. (2015) Microsporidia-host interactions. Curr Opin Microbiol. 26:10-16. 
Vávra J., Lukeš J. (2013) Microsporidia and 'the art of living together'. Adv Parasitol. 82:253-319.

Weiss L. M., Delbac F., Russell-Hayman J., Pan G., Dang X., Zhou Z. (2014) The microsporidian polar tube and spore wall, in: Weiss L. M., Becnel J. J. (Eds.) Microsporidia: Pathogens of Opportunity. Wiley-Backwell, Ames, Iowa, USA. pp. 261-306.

Weissenberg R. (1968) Intracellular development of the microsporidan Glugea anomala moniez in hypertrophying migratory cells of the fish Gasterosteus aculeatus L., an example of the formation of "xenoma" tumors. J Protozool. 15:44-57.

Yang D., Pan L., Chen Z., Du H., Luo B., Luo J., Pan G. (2018) The roles of microsporidia spore wall proteins in the spore wall formation and polar tube anchorage to spore wall during development and infection processes. Exp Parasitol. 187:93-100. 


\section{SUPPLEMENTARY MATERIAL}

Supplementary Table 1. Enterospora nucleophila infection status in the intestine of gilthead sea bream used as donors in the different infection trials. For qPCR diagnosis $(\mathrm{NL}=$ non-lethal; $\mathrm{L}=$ lethal), Ct values provided are the max-min range. Weeks are counted from the arrival of the infected fish to our facilities (week 0) until sampled. His-G = histology resin Giemsa-stained sections.

\begin{tabular}{|c|c|c|}
\hline Time (weeks) & Diagnostic method & Prevalence, $\mathrm{n}$ positive/sampled, intensity \\
\hline \multicolumn{3}{|c|}{ TRIAL 1} \\
\hline 0 & His-G & $30 \%(3 / 10)$ \\
\hline \multirow[t]{2}{*}{55} & His-G & $0 \%(0 / 6)$ \\
\hline & L-qPCR & $100 \%(6 / 6) \mathrm{Ct}: 31.3-37.9$ \\
\hline \multicolumn{3}{|c|}{ TRIAL 2} \\
\hline \multirow[t]{3}{*}{$\mathbf{0}$} & His-G & $40 \%(8 / 20)$ \\
\hline & L-qPCR & 95.8\% (23/24) Ct: 20.6-35.03 \\
\hline & NL-qPCR & 95\% (19/20) Ct: 20.3-35.3 \\
\hline 19 & NL-qPCR & $\begin{array}{l}\text { EF-2-LT: } 94.4 \%(17 / 18) \mathrm{Ct}: 34.2-36.8 \\
\text { EF-2-HT: } 100 \%(15 / 15) \mathrm{Ct}: 34.2-37.6\end{array}$ \\
\hline 25 & NL-qPCR & $\begin{array}{l}\text { EF-2-LT: } 20 \%(1 / 5) \mathrm{Ct}: 37.5 \\
\text { EF-2-HT: } 20 \%(3 / 15) \mathrm{Ct}: 37.9-38\end{array}$ \\
\hline \multicolumn{3}{|c|}{ TRIALS 3 and 4} \\
\hline $\mathbf{0}$ & L-qPCR & $100 \%(22 / 22) \mathrm{Ct}: 20.1-37.8$ \\
\hline 9 & L-qPCR & 80\% (8/10) Ct: 27.2-32.2 \\
\hline \multirow[t]{2}{*}{10} & L-qPCR & $50 \%(2 / 4) \mathrm{Ct}: 35.4-35.6$ \\
\hline & His-G & $25 \%(2 / 8)$ \\
\hline \multirow[t]{2}{*}{11} & L-qPCR & $50 \%$ (4/8) Ct: $31.4-36$ \\
\hline & His-G & $0 \%(0 / 8)$ \\
\hline 15 & L-qPCR & 40\% (8/20) Ct: 31.5-37.8 \\
\hline 21 & L-qPCR & 57.1\% (8/14) Ct: 32.8-37.1 \\
\hline 45 & L-qPCR & 60\% (6/10) Ct: 29.8-37.7 \\
\hline 48 & L-qPCR & $18.2 \%(2 / 11) \mathrm{Ct}: 35.4-37$ \\
\hline
\end{tabular}


CHAPTER 6 


$$
270
$$

. 
1. Gilthead sea bream surviving an Enteromyxum leei infection, do not get re-infected when experimentally challenged. This acquired resistance lasts up to 16 months.

2. High levels of circulating E. leei-specific IgM before exposure are correlated with the acquired resistance to the infection.

3. Resistant fish re-exposed to E. leei do not exhibit enteromyxosis signs and show an inflammation resolution transcriptomic phenotype in the intestine and the head kidney.

4. Cell cytotoxicity, peroxidases, and complement contribute to acquired resistance against $E$. leei.

5. One week of exposure to $E$. leei-contaminated effluent is enough to effectively transmit this disease, both at moderate $\left(18^{\circ} \mathrm{C} \pm 0.5^{\circ} \mathrm{C}\right)$ and high water temperature $\left(25.6^{\circ} \mathrm{C} \pm 1.9^{\circ} \mathrm{C}\right)$.

6. Higher water temperature is correlated with higher prevalence of $E$. leei infection. However, higher temperature also boosts the antibody response leading to a lower parasite spreading along the fish intestine.

7. At lower water temperature, the variables time of exposure, cohabitation with infected animals and fish density are more relevant. The effect of high temperature masks these variables. Low water temperature showed higher differences in prevalence of infection than higher temperatures, regarding time of exposure and density.

8. Passive immunization with parasite-specific antibodies can delay the initial propagation of E. leei in naïve gilthead sea bream and the appearance of disease signs.

9. Immunoglobulin repertoire analysis of E. leei resistant fish shows that the parasite induces a differential IgM and IgT response in gilthead sea bream characterized by a polyclonal expansion of diverse Ig subsets. This polyclonal expansion suggests an immune-evasion mechanism elicited by the parasite, aimed to dilute parasite-specific antibodies increasing the proportion of irrelevant antibodies. Nonetheless, resistant gilthead sea bream are still able to produce enough specific antibodies to avoid infection. 
10. A de novo transcriptome of 14,356 E. leei transcripts has been built using a customized pipeline to separate fish and parasite transcripts after transcript assembly.

11. In silico analysis and characterisation of transcripts of the new transcriptome allowed the selection of three highly expressed transcripts, with external location, and with similarities with other myxozoan species to be used in diagnostic tools development.

12. Proteomic analysis, using transcriptomic information and E. leei specific antibodies from resistant fish, allowed the selection of 12 antigenic transcripts to be tested in vaccine development.

13. The most evident clinical signs of Enterospora nucleophila infection in gilthead sea bream are arrested growth, emaciation and thinned intestinal walls. There is a negative correlation between condition factor and intensity of infection.

14. The most evident histopathological signs of heavy E. nucleophila infections in gilthead sea bream intestine are enterocyte hypercellularity, proliferation of rodlet cells, large number of lymphocytes at the base of the mucosa and eosinophilic granular cells located between the enterocytes. In the submucosa, granulomata composed of macrophage aggregates containing spores and surrounded by lymphocytes and granulocytes are commonly found. Mast cells, $\operatorname{IgM}^{+}$and IgT ${ }^{+} \mathrm{B}$ cells are also very abundant in the submucosa.

15. Horizontal transmission of E. nucleophila can be successfully achieved by oral, anal intubation, effluent and cohabitation challenge. However, a decrease in parasite prevalence in intestine over time is detected using all routes of transmission except for anal intubation, which appears to be the most promising transmission method. In any case, the clinical disease signs of naturally infected fish could not be fully reproduced with experimental transmission.

16. E. nucleophila prevalence is higher in intestine at the beginning the outbreak, but in subsequent months, it decreases and increases in hematopoietic organs and stomach.

17. Water temperature, time of exposure, infective status of donor fish and immunocompetence of recipient fish are relevant for E. nucleophila horizontal transmission, possibly more than the challenge route per se. 


